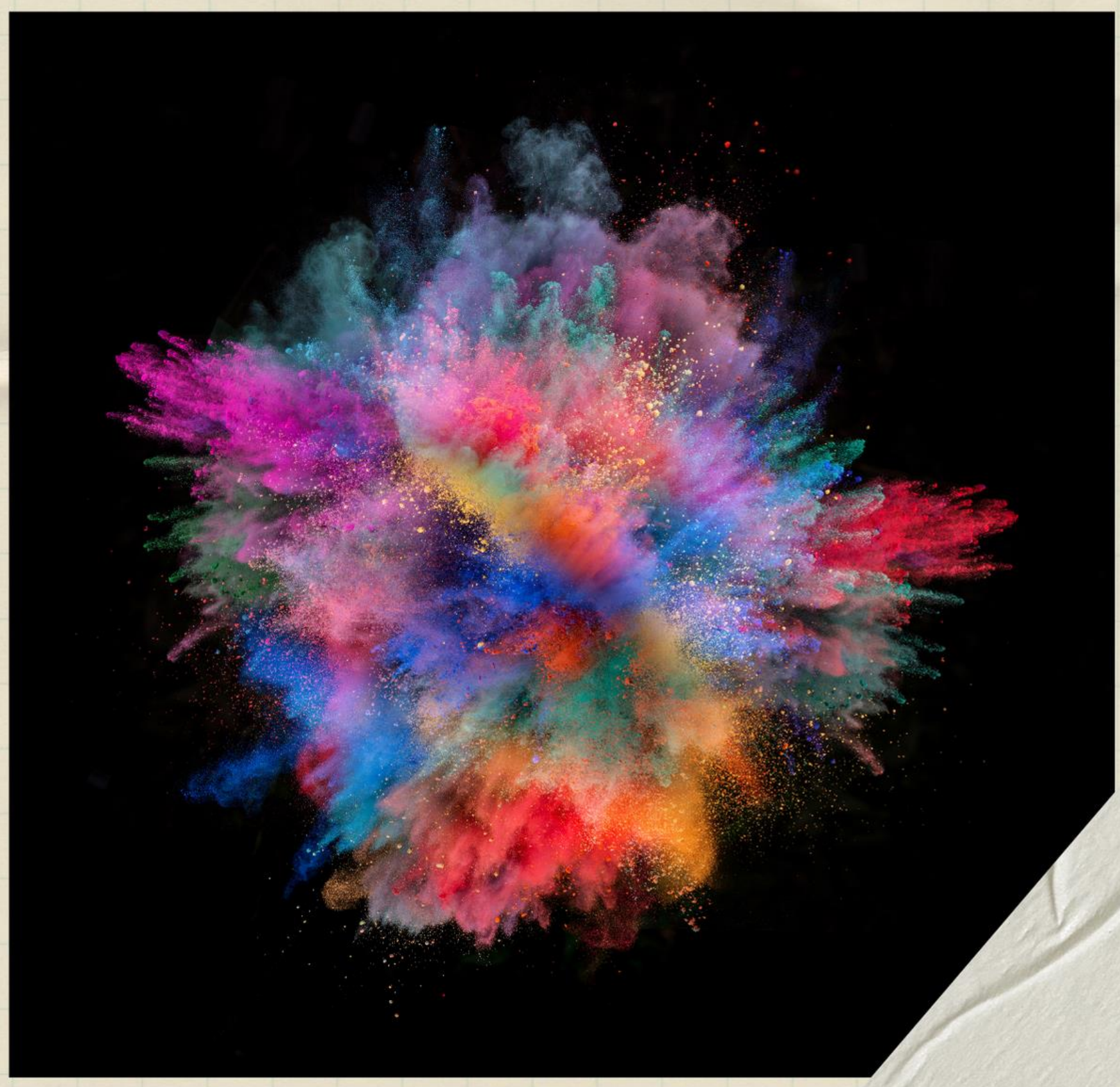

\title{
PIGMENTOS E CORANTES
}
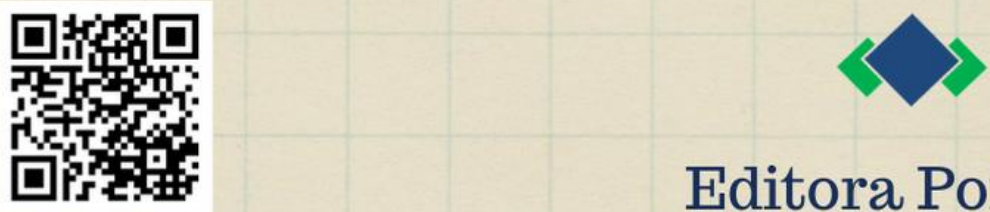

$1^{\circ}$ Edição 2021

Editora Poisson 
Maria da Conceição Tavares Cavalcanti Liberato

(Organizadores)

\section{Pigmentos e Corantes}

1a Edição

Belo Horizonte

Poisson

2021 


\section{Editor Chefe: Dr. Darly Fernando Andrade}

\section{Conselho Editorial}

Dr. Antônio Artur de Souza - Universidade Federal de Minas Gerais

Ms. Davilson Eduardo Andrade

Dra. Elizângela de Jesus Oliveira - Universidade Federal do Amazonas

Msc. Fabiane dos Santos

Dr. José Eduardo Ferreira Lopes - Universidade Federal de Uberlândia

Dr. Otaviano Francisco Neves - Pontifícia Universidade Católica de Minas Gerais

Dr. Luiz Cláudio de Lima - Universidade FUMEC

Dr. Nelson Ferreira Filho - Faculdades Kennedy

Ms. Valdiney Alves de Oliveira - Universidade Federal de Uberlândia

Dados Internacionais de Catalogação na Publicação (CIP)

P631

Pigmentos e Corantes / Organização: LIBERATO, Maria da Conceição

Tavares Cavalcanti - Belo Horizonte- MG: Poisson, 2021

Formato: PDF

ISBN: 978-65-5866-076-7

DOI: 10.36229/978-65-5866-076-7

Modo de acesso: World Wide Web

Inclui bibliografia

1.Química 2.Pigmentos 3. Corantes I. LIBERATO, Maria da Conceição Tavares Cavalcanti. III.Título

CDD-660.6

Sônia Márcia Soares de Moura - CRB 6/1896

O conteúdo dos artigos e seus dados em sua forma, correção e confiabilidade são de responsabilidade exclusiva dos seus respectivos autores.

www.poisson.com.br

contato@poisson.com.br 


\section{Sobre a Organizadora}

\section{Maria da Conceição Tavares Cavalcanti Liberato}

Graduada em Química Industrial pela Universidade Federal do Ceará (UFC), Especialista em Química Orgânica pela Universidade Federal do Rio de Janeiro (UFRJ), Mestre em Tecnologia de Alimentos pela Universidade Federal do Ceará (UFC), Doutora em Biotecnologia pela Rede Nordeste de Biotecnologia (RENORBIO), Professora Associada com Dedicação Exclusiva do Curso de Licenciatura em Química da Universidade Estadual do Ceará (UECE) e Professora colaboradora do Mestrado em Recursos Naturais (MARENA) da Universidade Estadual do Ceará (UECE). 


\section{Prefácio}

Quando se entra em um supermercado ou feira de alimentos logo nossa atenção se volta para as bancas cheias de frutas, legumes e verduras. 0 que nos provoca olhar atentamente e às vezes sentir de imediato o desejo de degustar tais alimentos? Com certeza a variedade de cores que enchem os nossos olhos e os aromas que invadem os nossos narizes são os responsáveis. É interessante perceber que até nossos pensamentos ficam "contaminados" com as cores e os aromas pois de pronto imaginamos quantas iguarias poderiam surgir a partir daqueles alimentos. Mas será que sabemos exatamente o que contém cada um daqueles alimentos de cores tão chamativas? Com certeza não.

Como professora da disciplina de Química dos Alimentos para estudantes de Química da Universidade Estadual do Ceará, sempre desejei falar de pigmentos e corantes nos alimentos com meus alunos, mas nem sempre o tempo era suficiente, por isso resolvi lançar esse livro. Espero que não apenas os meus alunos e ex-alunos que participaram criando jogos para esse livro, se beneficiem com os jogos que de forma divertida mostram o potencial representativo de cada alimento.

Desejo que todos que tiverem contato com esse livro aprendam bastante sobre alimentos e suas potencialidades e ao sentarem-se à mesa olhem com respeito e admiração o colorido que aparece em seus pratos. Esse livro complementa através da atividade dos jogos outros textos e espero que seja de imediato interesse dos alunos atuais e dos que já ocupam a cátedra de Química dos Alimentos. Além disso esse trabalho também tem valor para leigos que porventura desejem de modo lúdico saber mais sobre os alimentos que consomem, por isso a todos esses alunos, ex-alunos e leigos dedico esse livro.

Finalmente agradeço a todos os alunos que aceitaram a ideia da realização desse trabalho, especialmente a bolsista da Pró-Reitoria de Extensão (PROEX) e aluna do Curso de Química da Universidade Estadual do Ceará (UECE) Geovana Costa Aguiar pela participação na elaboração desse livro. 


\section{SUMÁRIO}

Jogo 1: A festa dos corantes.

Sarah Geysa de Oliveira Ribeiro, Apoena Silva Araújo, Maria da Conceição Tavares Cavalcanti Liberato DOI: 10.36229/978-65-5866-076-7.CAP.01

Jogo 2: Verdadeiro ou falso, a verdade sobre corantes e pigmentos.

João Vitor Araújo Souza, Layonara Dhuly da Silva Teixeira, Maria da Conceição Tavares Cavalcanti Liberato DOI: 10.36229/978-65-5866-076-7.CAP.02

Jogo 3: Você conhece as BETALAÍNAS?

Vitor Rocha de Carvalho, Maria da Conceição Tavares Cavalcanti Liberato

DOI: 10.36229/978-65-5866-076-7.CAP.03

Jogo 4: Duelo. 40

João Vitor Araújo Souza, Layonara Dhuly da Silva Teixeira, Maria da Conceição Tavares Cavalcanti Liberato DOI: 10.36229/978-65-5866-076-7.CAP.04

Jogo 5: É corante mesmo! 46

Francinildo da Silva Brito, Maria da Conceição Tavares Cavalcanti Liberato

DOI: $10.36229 / 978-65-5866-076-7 . C A P .05$

Jogo 6: Quimiquest: Estrada da cor 52

Cecília Guimarães Lemos, Maria da Conceição Tavares Cavalcanti Liberato

DOI: 10.36229/978-65-5866-076-7.CAP.06

Jogo 7: Corrida das cores.

Layonara Dhuly da Silva Teixeira, João Vitor Araújo Souza, Maria da Conceição Tavares Cavalcanti Liberato DOI: 10.36229/978-65-5866-076-7.CAP.07

Jogo 8: Memória em cores.. 74

João Vitor Araújo Souza, Layonara Dhuly da Silva Teixeira, Maria da Conceição Tavares Cavalcanti Liberato DOI: 10.36229/978-65-5866-076-7.CAP.08 


\section{SUMÁRIO}

Jogo 9: Trilha 80

Kaio Medeiros Teles Cavalcante, Liz Roberta Silva Lima, Everson da Silva Gomes, Caio Santos Cabral, Maria da Conceição Tavares Cavalcanti Liberato

DOI: 10.36229/978-65-5866-076-7.CAP.09

Jogo 10: Investigador .88

Dayanne Cipriano Costa da Silva, Maria da Conceição Tavares Cavalcanti Liberato

DOI: $10.36229 / 978-65-5866-076-7 . C A P .10$

Jogo 11: Mestre das palavras .98

Dayanne Cipriano Costa da Silva, Maria da Conceição Tavares Cavalcanti Liberato

DOI: $10.36229 / 978-65-5866-076-7 . C A P .11$

Jogo 12: Quem sou eu? 106

Dayanne Cipriano Costa da Silva, Maria da Conceição Tavares Cavalcanti Liberato

DOI: $10.36229 / 978-65-5866-076-7 . C A P .12$

Jogo 13: Jogo do impostor 1 (Pigmentos e Corantes)

Letícia de Araújo Rodrigues, Pedro Filipe Lemos Vieira, Maria da Conceição Tavares Cavalcanti Liberato DOI: $10.36229 / 978-65-5866-076-7 . C A P .13$

Jogo 14: Jogo do impostor 2 (Pigmentos e Corantes) 127

Itamara Gomes de Sousa, Maria da Conceição Tavares Cavalcanti Liberato

DOI: 10.36229/978-65-5866-076-7.CAP.14

Jogo 15: Pigcolor: Alimentos em cores. 137

Milena Lira Rocha, Camile Rabelo de Medeiros, Cecília Guimarães Lemos, Vitória Ellen Lima Bantim, Maria Da Conceição Tavares Cavalcanti Liberato

DOI: 10.36229/978-65-5866-076-7.CAP.15

Jogo 16: Jogo das Fichas 147

Elane Cartaxo Nogueira, Eveliny Sombra Mota, Francisca Yhaskara Gomes da Silva, Patrícia Hellen da Silva Cavalcante, Maria Da Conceição Tavares Cavalcanti Liberato

DOI: $10.36229 / 978-65-5866-076-7 . C A P .16$ 


\section{SUMÁRIO}

Jogo 17: Dominó de corantes e pigmentos em libras.

150

Gustavo Henrique Gomes Teixeira, José Augusto Fernandes de Meneses, Maria da Conceição Tavares Cavalcanti Liberato

DOI: $10.36229 / 978-65-5866-076-7 . C A P .17$

Jogo 18: Three Clues

Dayanne Cipriano Costa da Silva, Maria da Conceição Tavares Cavalcanti Liberato

DOI: $10.36229 / 978-65-5866-076-7 . C A P .18$

Jogo 19: Jogo de Cartas: Corantes e Pigmentos.

Alisson Marley Rodrigues Alcantara, Chrislane Barbosa de Sousa, Álvaro Ventorini Vasconcelos, Geovana Costa Aguiar, Maria da Conceição Tavares Cavalcanti Liberato

DOI: $10.36229 / 978-65-5866-076-7 . C A P .19$

Jogo 20: Operação Secreta 173

Dayanne Cipriano Costa da Silva , Maria da Conceição Tavares Cavalcanti Liberato DOI: $10.36229 / 978-65-5866-076-7 . C A P .20$ 


\section{Jogo 1}

\section{A festa dos corantes}

Sarah Geysa de Oliveira Ribeiro

Apoena Silva Araújo

Maria da Conceição Tavares Cavalcanti Liberato 


\section{INTRODUÇÃO}

Ao mesmo tempo em que o consumo de alimentos industrializados é cada vez maior, a origem das cores de tais alimentos acaba passando despercebida, de acordo Collins e Plumbly (1995); Freund et al. (1988), citado por Constant, Stringheta e Sandi (2002) a aceitação do produto alimentício pelo consumidor está diretamente relacionada a sua cor. Esta característica sensorial, embora subjetiva, é fundamental na indução da sensação global resultante de outras características como o aroma, o sabor e a textura dos alimentos. Desta forma, a aparência do alimento pode exercer efeito estimulante ou inibidor do apetite. Além de necessária para a sobrevivência, a alimentação também é fonte de prazer e satisfação. Por essa razão, o setor alimentício preocupa-se tanto com a aplicação de cores e obtenção de alimentos que agradem aos olhos do consumidor.

Os corantes artificiais são os mais utilizados pelas indústrias por apresentarem menores custos de produção e maior estabilidade em comparação aos corantes naturais. Contudo, diversos relatos na literatura científica indicam que os corantes artificiais causam prejuízo a saúde (B00, et al, 2012, p. 129, citado por Rodella; Souza, 2013).

A preocupação crescente com as reações adversas que os corantes artificiais podem causar as pessoas tem deslocado interesse para os corantes naturais, já que os corantes naturais oferecem vários benefícios à saúde, podendo apresentar propriedades importantes tais como antioxidantes e anti-inflamatórias (RODELLA; SOUZA, 2013).

Dada a importância dessa discussão para a sociedade como um todo, resolveu-se elaborar o jogo "A festa dos Corantes", para incentivar o estudo das possíveis reações que os corantes artificiais podem causar, e demonstrar aos jogadores/alunos, através de uma atividade didática, que existem alternativas naturais para substituí-los. Tendo em vista que conseguir capturar o interesse dos alunos em sala de aula é um dos maiores obstáculos que um professor tem que lidar no cotidiano da profissão, principalmente em química, que descreve processos que ocorrem em escalas tão diminutas que dificultam a visualização e o entendimento do aluno, os professores precisam usar sua criatividade para desenvolver métodos que facilitem a compreensão sobre o conteúdo de forma ilustrativa e interessante.

As melhores ações em termos de sala de aula são aquelas que desenvolvem a capacidade de tomada de decisão (ROSA, 2004, citado por FELÍCIO, 2011). Tendo isto em mente elaboramos o jogo "A festa dos corantes" seguindo uma jogabilidade inspirada em Role Playing Game (RPG) que de acordo com Marcondes (2004), citado por Cavalcanti e Soares (2009), é uma grande aventura, em que um dos participantes, o narrador, chamado de mestre, conduz a partida ou jogo, descrevendo o ambiente, interpretando personagens que os jogadores encontrarão pelo caminho, organizando as questões das regras a serem testadas e determinando os resultados das ações, mas são os jogadores que decidem o que seus personagens vão dizer ou fazer. Toledo (2015) acrescenta que o RPG pode ser responsável por ajudar o aluno a desenvolver sua autonomia, pois em um mundo onde se está em constante evolução, isto requer que aos indivíduos aprendam a conviver com as incertezas, dúvidas, desafios e imprevistos. 


\section{MATERIAL E MÉTODOS}

O jogo "A festa dos corantes" é um jogo de tabuleiro que segue uma história ambientada em um supermercado. Na história o jogador encarna um jovem estudante de química que foi incumbido por sua mãe, da missão de comprar os comes e bebes do aniversário de sua irmã mais nova; tendo em mente que ela tem alergia a alguns corantes artificiais.

A jogabilidade do jogo segue uma história com estrutura semelhante à um roleplaying, em que um narrador (professor) vai descrevendo as situações e missões que o jogador deve seguir, são oferecidos vários produtos em formas de cartas explicativas, o objetivo do jogo é que o jogador opte pelo produto que apresente menos (ou nenhum) corante artificial, completando assim uma festa de aniversário perfeita!

Jogadores: 0 jogo pode ser jogado por 1 ou mais jogadores ou ainda grupos de jogadores que tomam as decisões em conjunto. Para aumentar a dificuldade do jogo os jogadores deverão escolher a carta correta de resposta em 1 minuto cronometrados pelo narrador (professor).

Narrador: 0 jogo precisa de um narrador para descrever as situações, ler as cartas de missão e apresentar a resposta correta que se encontra nelas. 0 narrador deverá ler as perguntas e aplicar as penalidades por exemplo:

Caso um jogador escolha o item errado para responder a carta de perguntas, ele deve perder a rodada e só avançar as casas correspondentes ao item certo na próxima rodada, para que então na rodada após a próxima ele volte a responder o fluxo de perguntas normalmente.

Componentes do jogo: Apresenta 1 tabuleiro (Anexo 1) + 14 cartas perguntas (Anexo 3 que servem pra orientar o jogador e devem ser lidas pelo narrador) +38 cartas de produtos (Anexo 2). 
Anexo 1

Tabuleiro do jogo

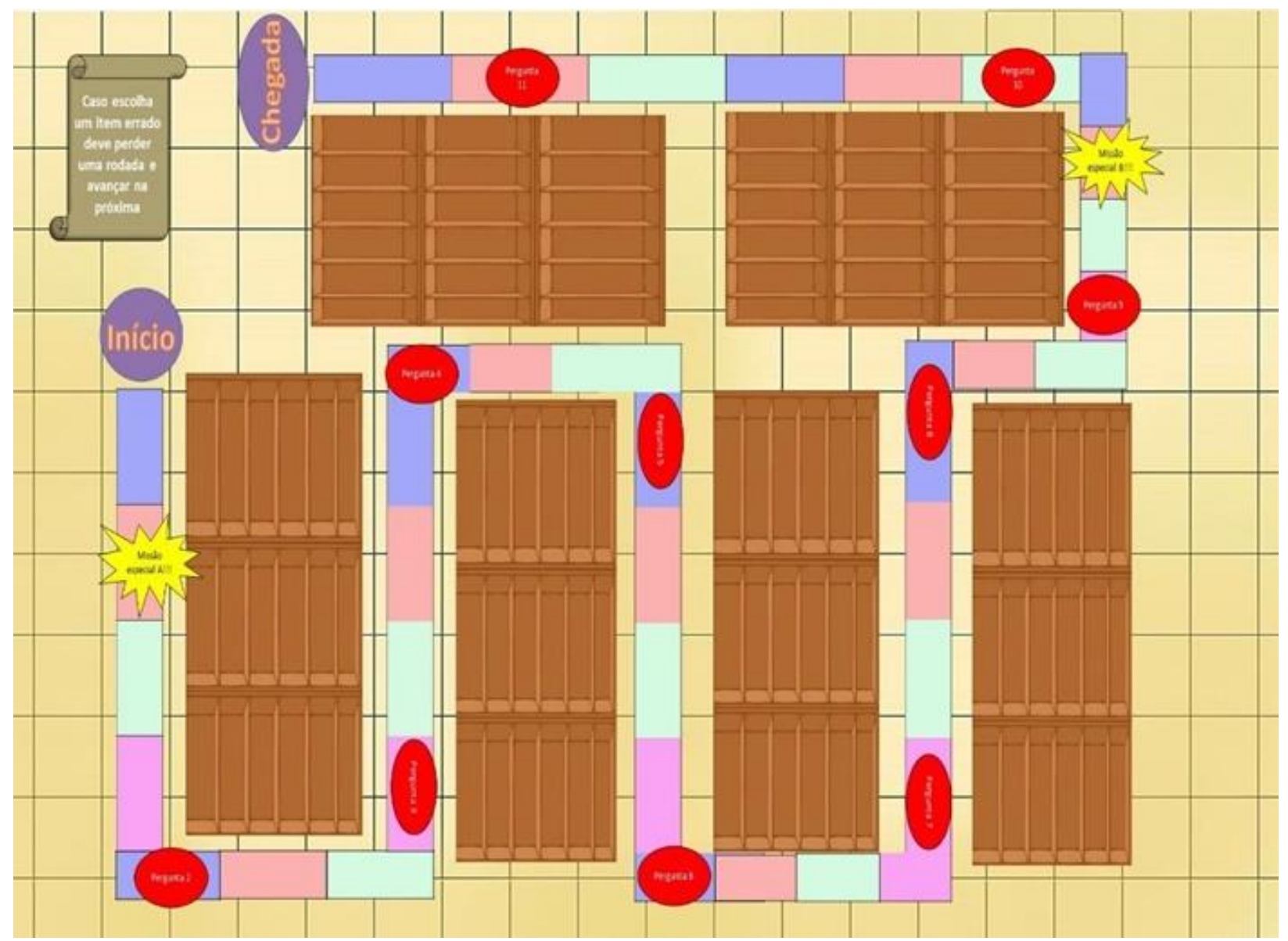




\section{Anexo 2}

\section{Cartas de respostas produtos estão na ordem cronológica do jogo}

\section{Respostas para a pergunta $1 \mathrm{H}$}
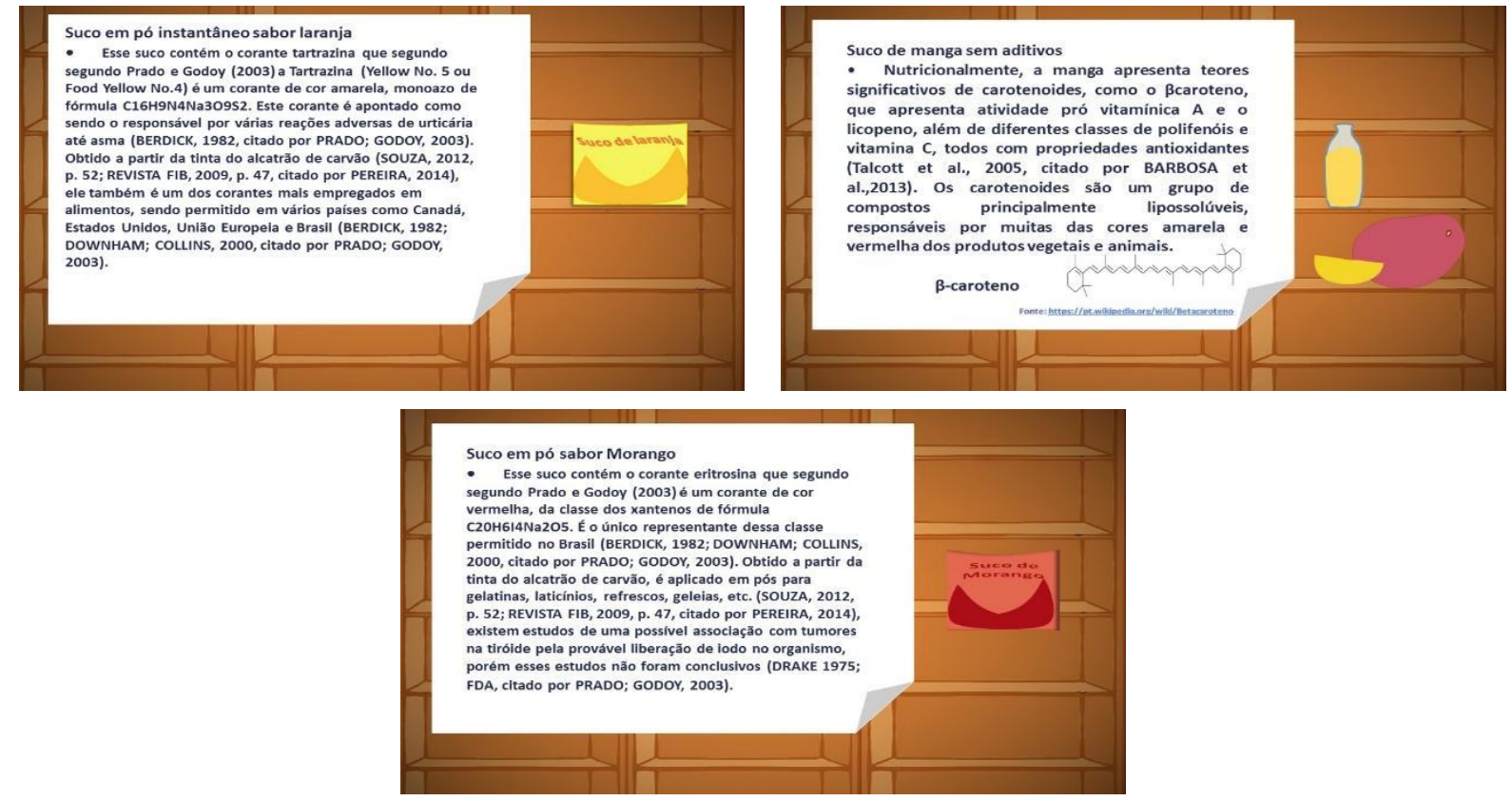

\section{Respostas para a missão especial $\mathrm{A}$}
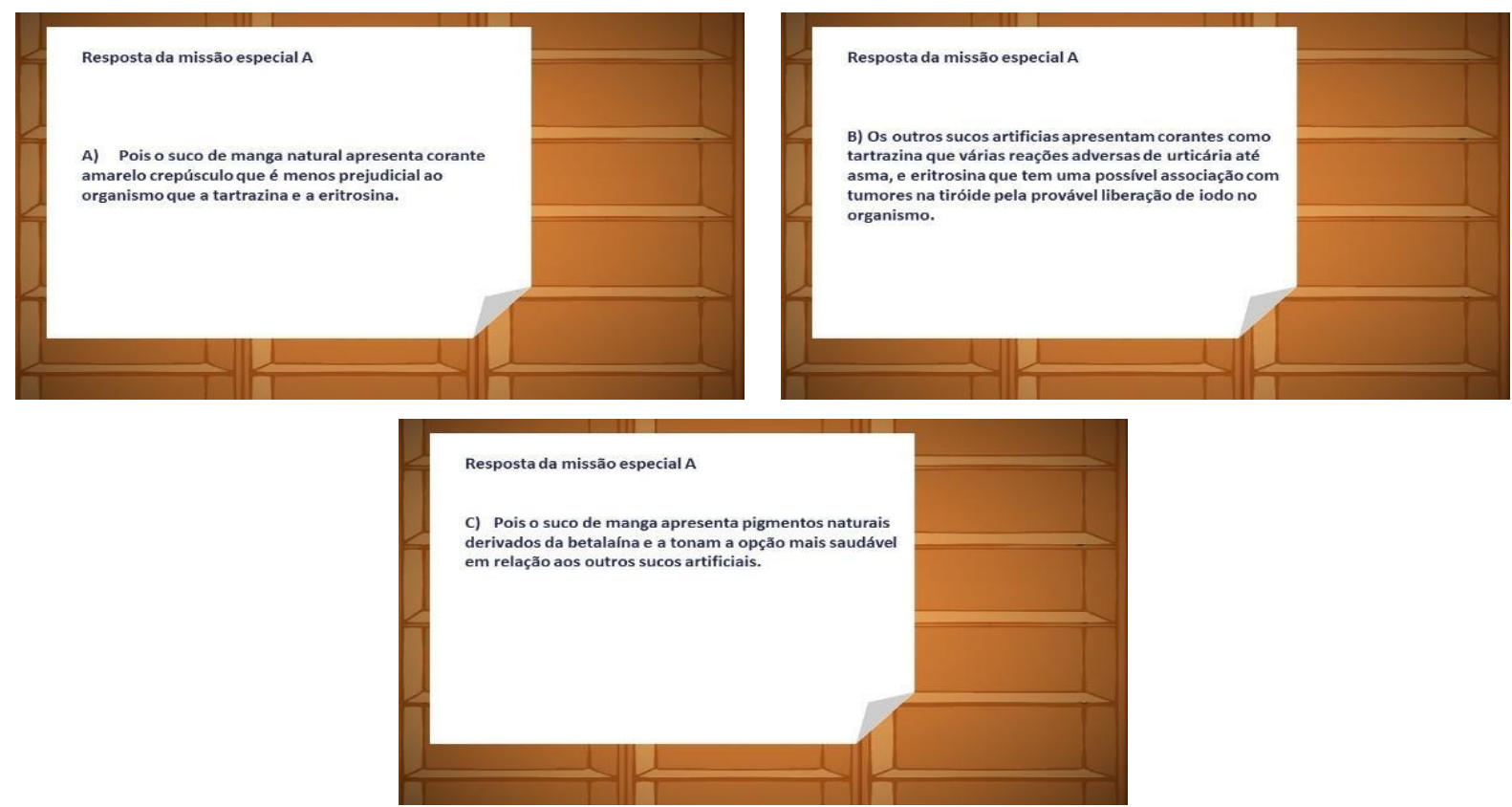


\section{Respostas para pergunta 2}
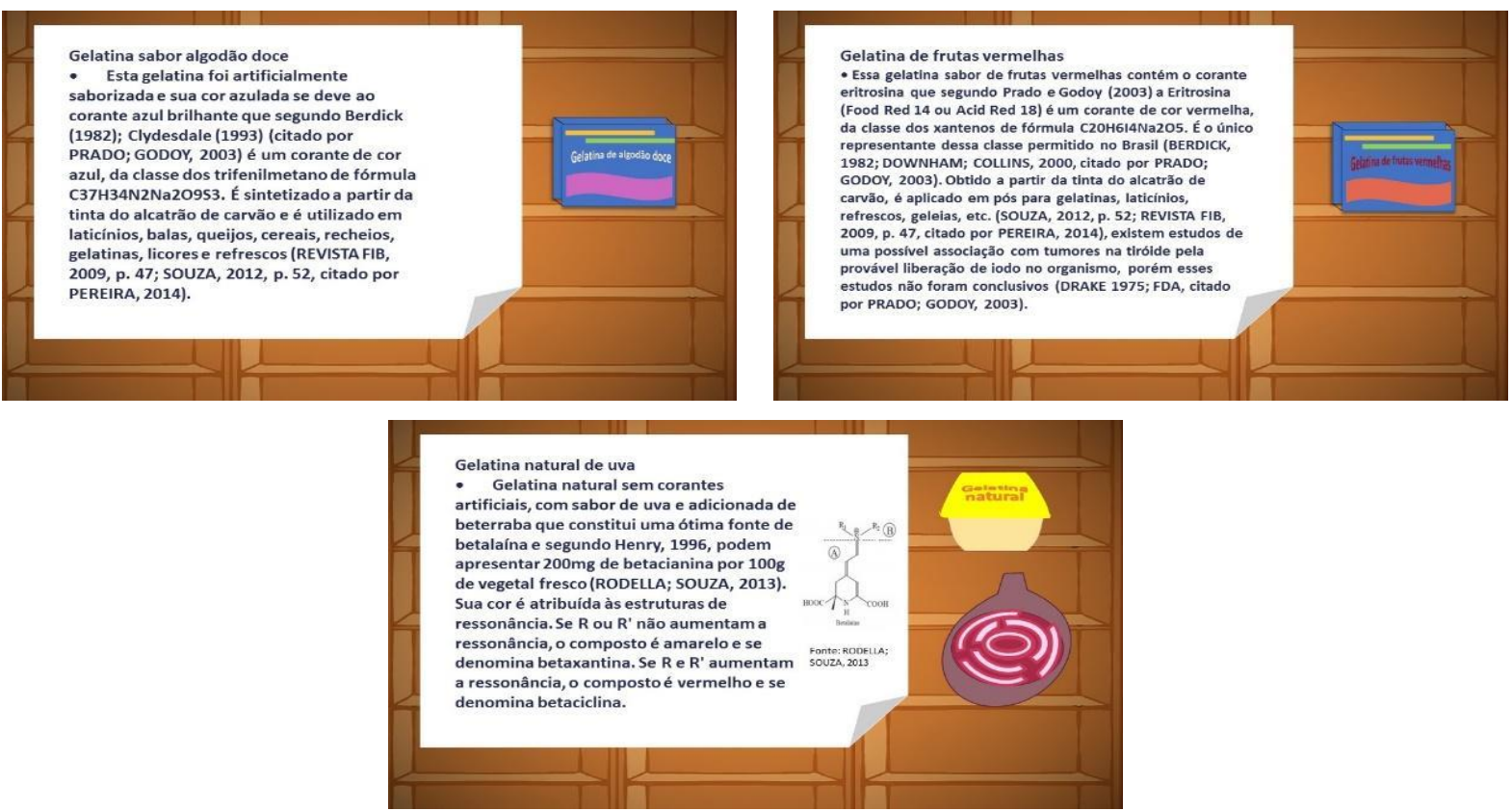

\section{Resposta para a pergunta 3}
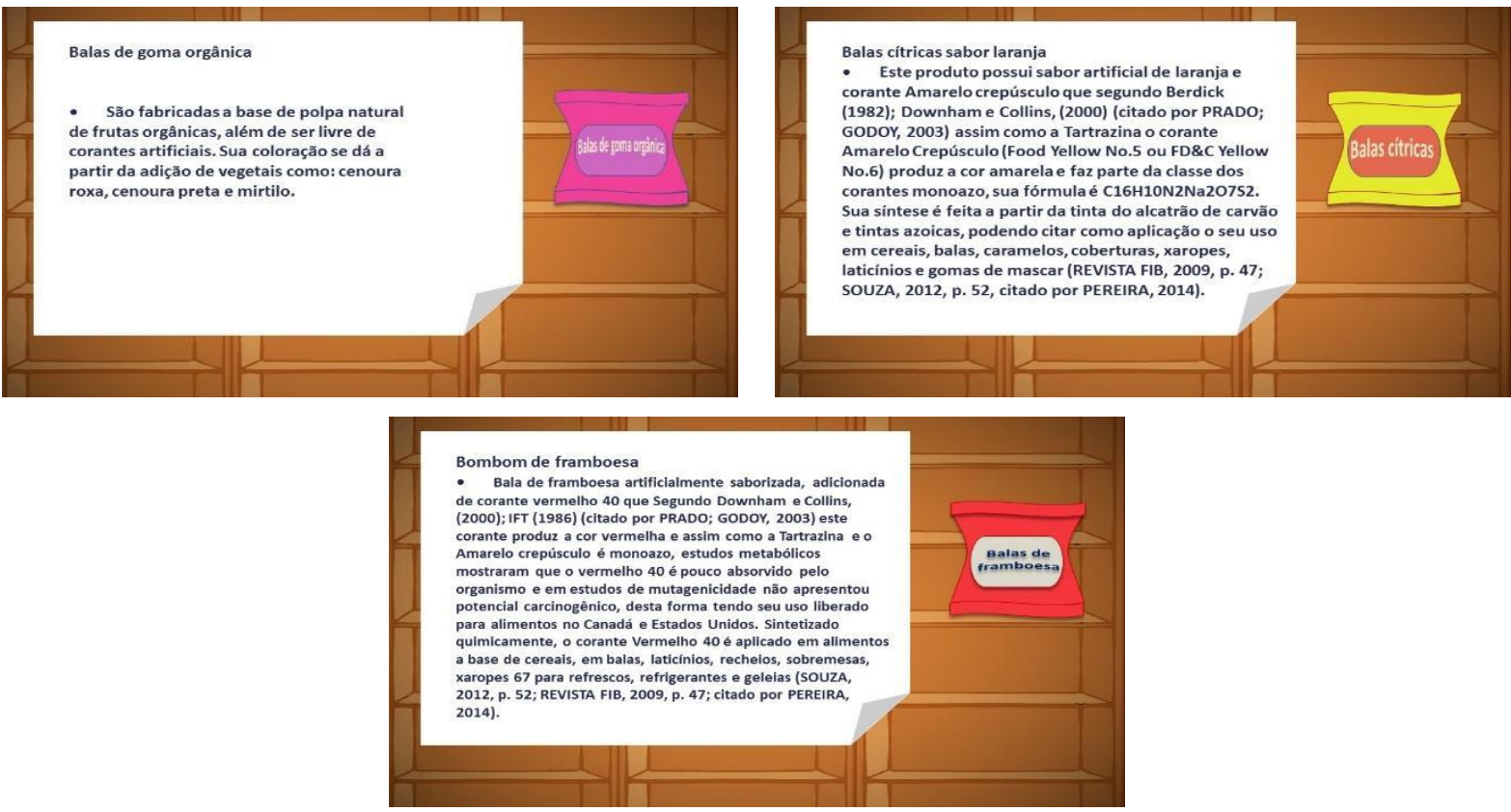


\section{Respostas para a pergunta 4}
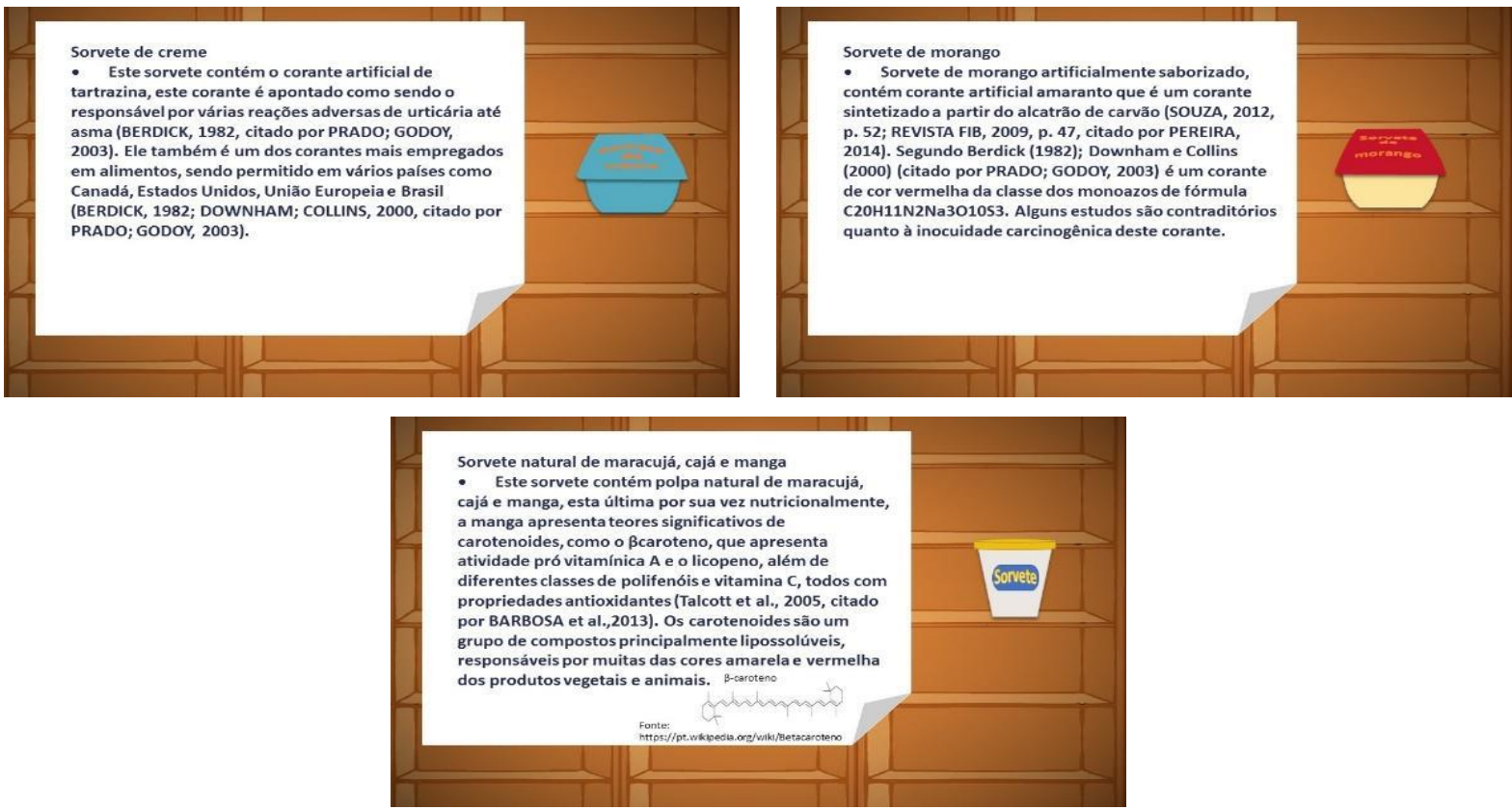

\section{Respostas para a pergunta 5}
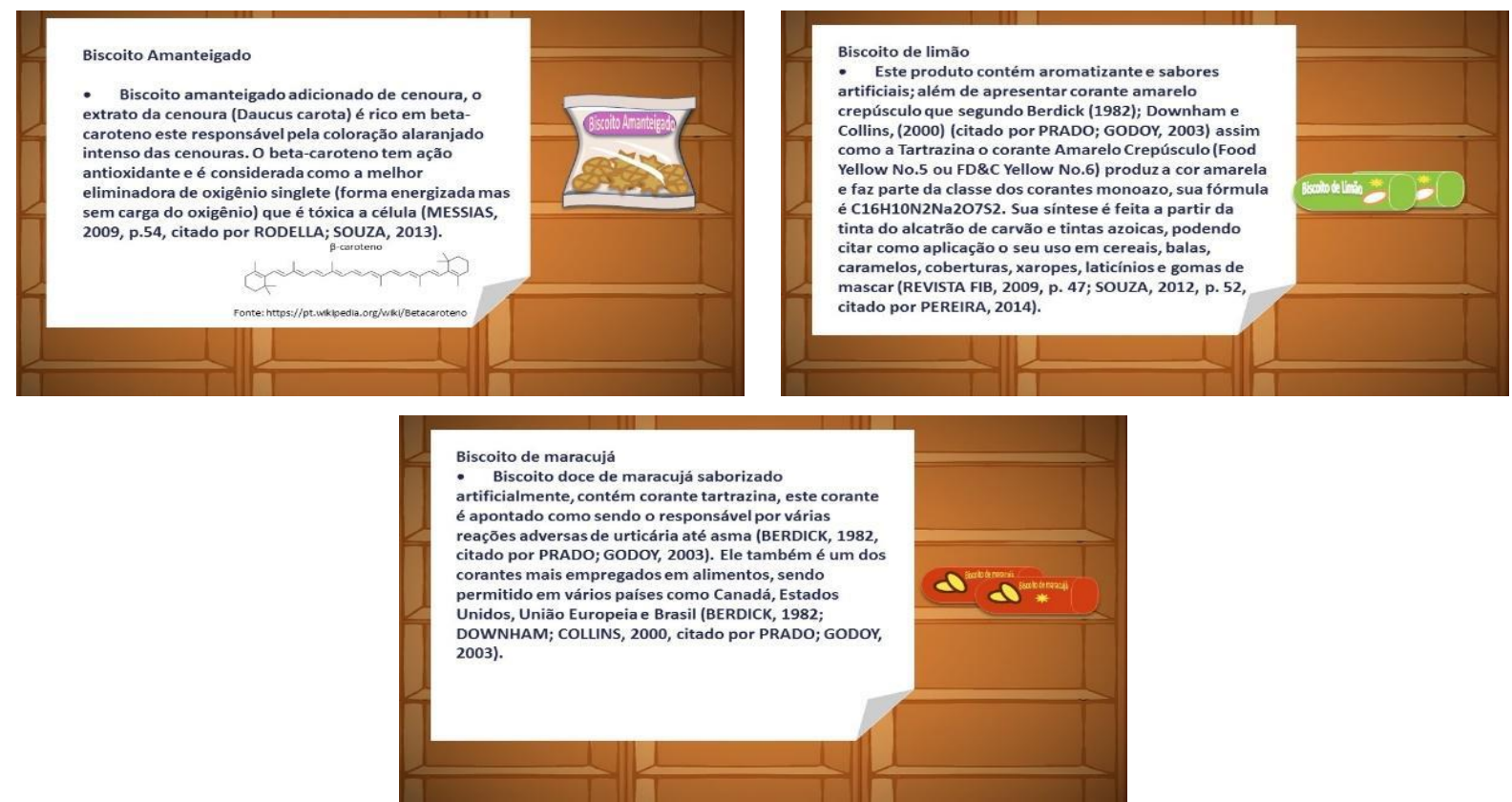


\section{Resposta da pergunta 6}
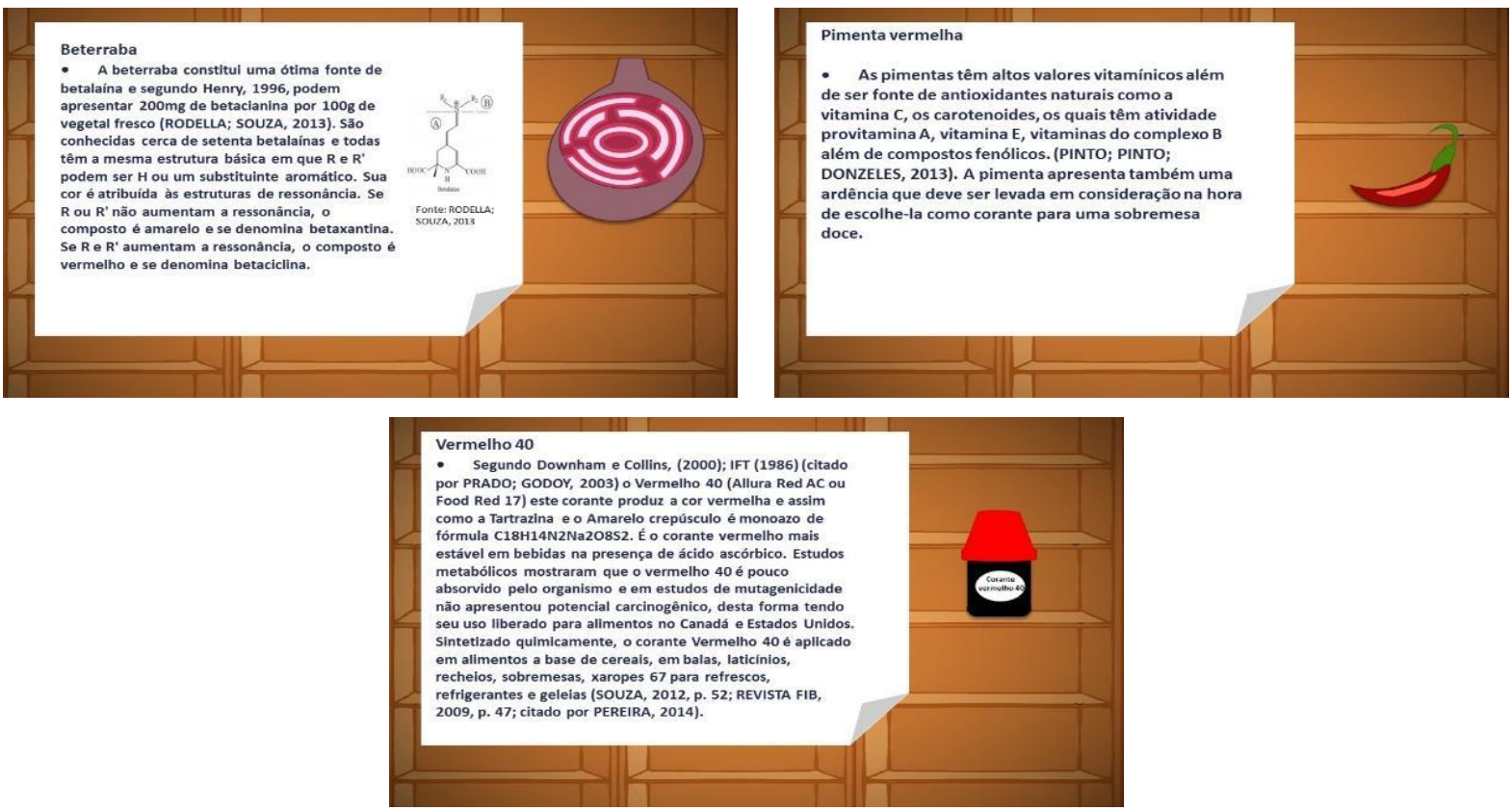

\section{Resposta da pergunta 7}
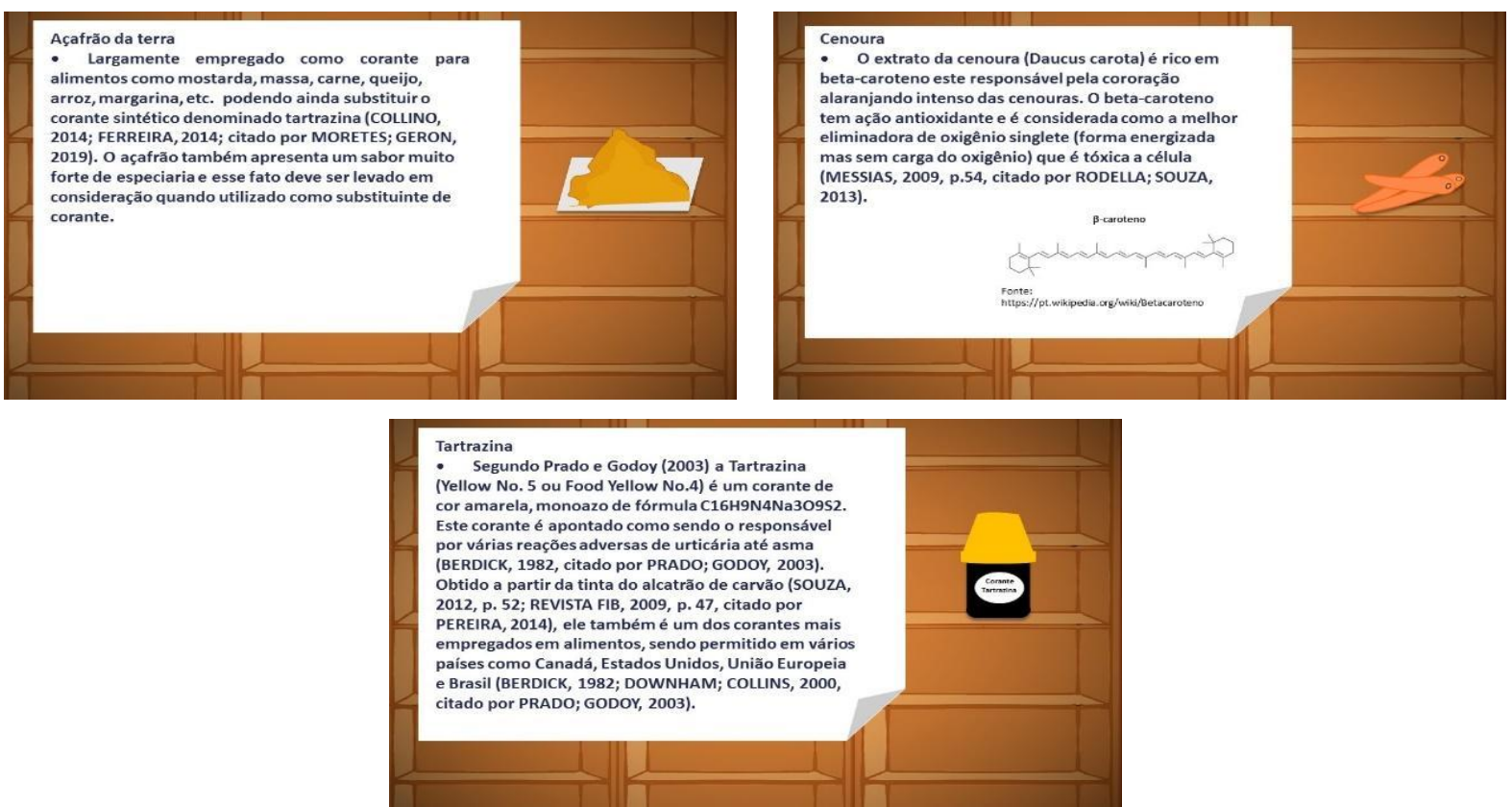


\section{Respostas para a pergunta 8}
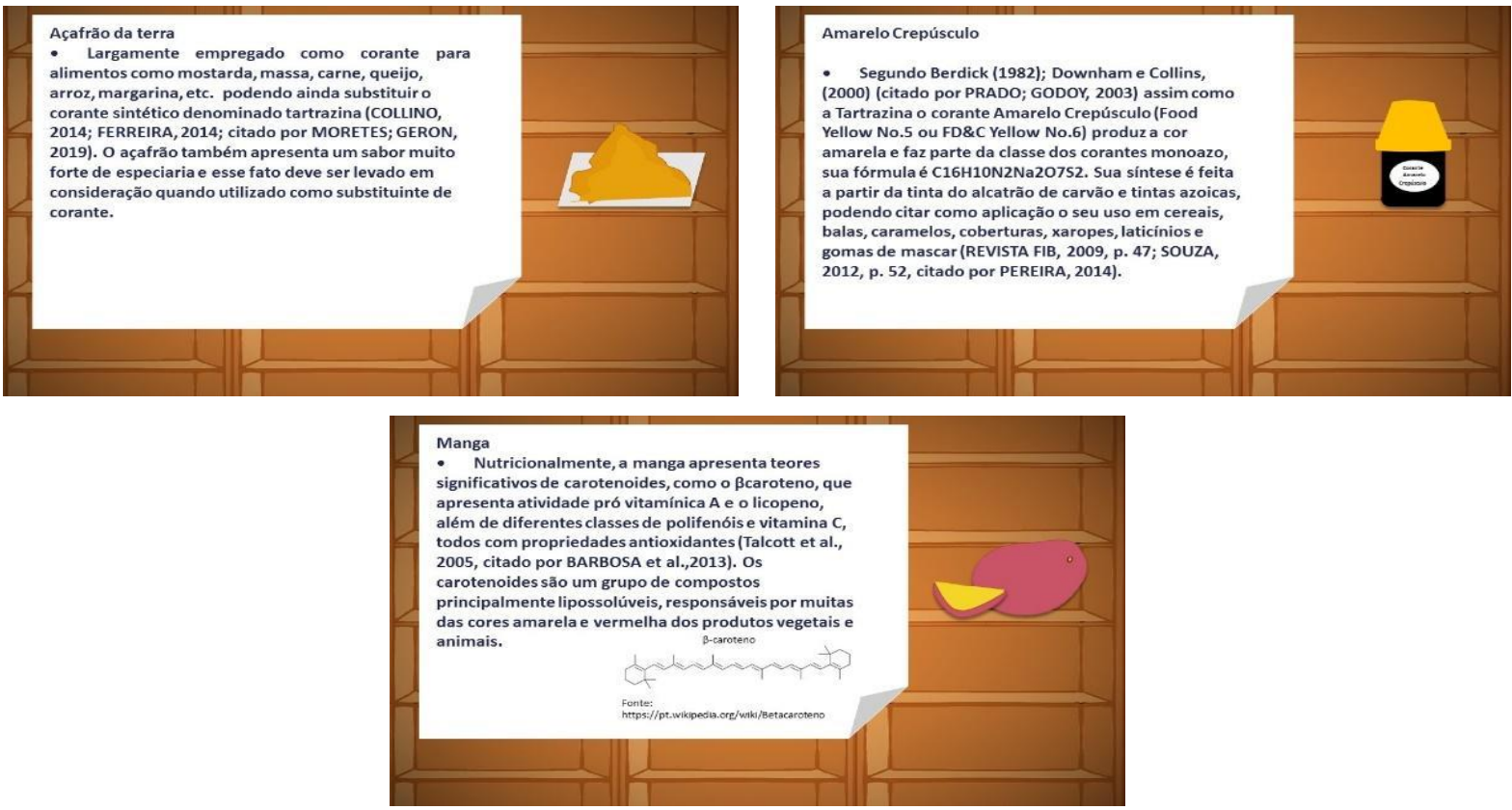

\section{Respostas para a pergunta 9}
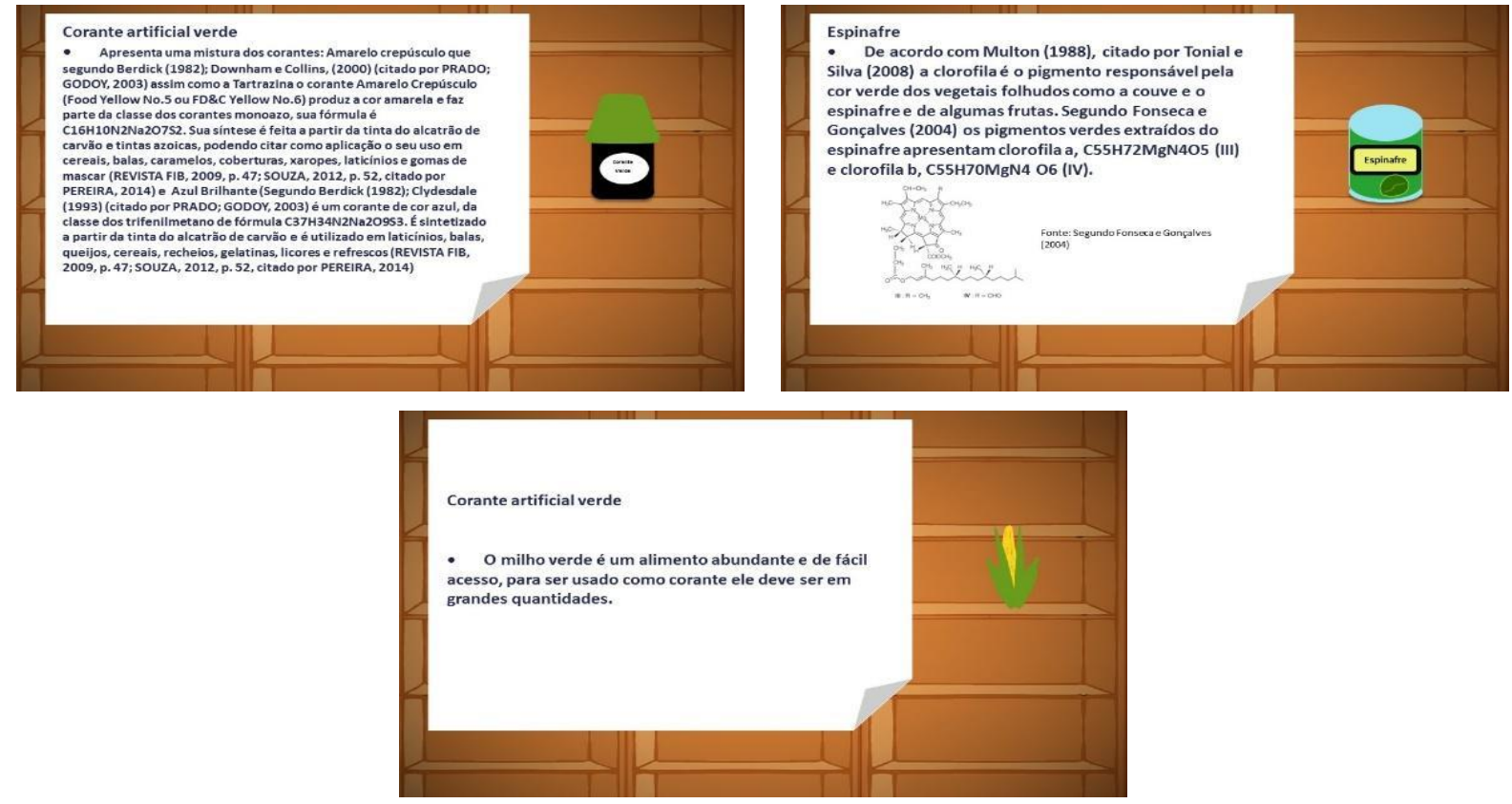


\section{Respostas para a Missão especial B}
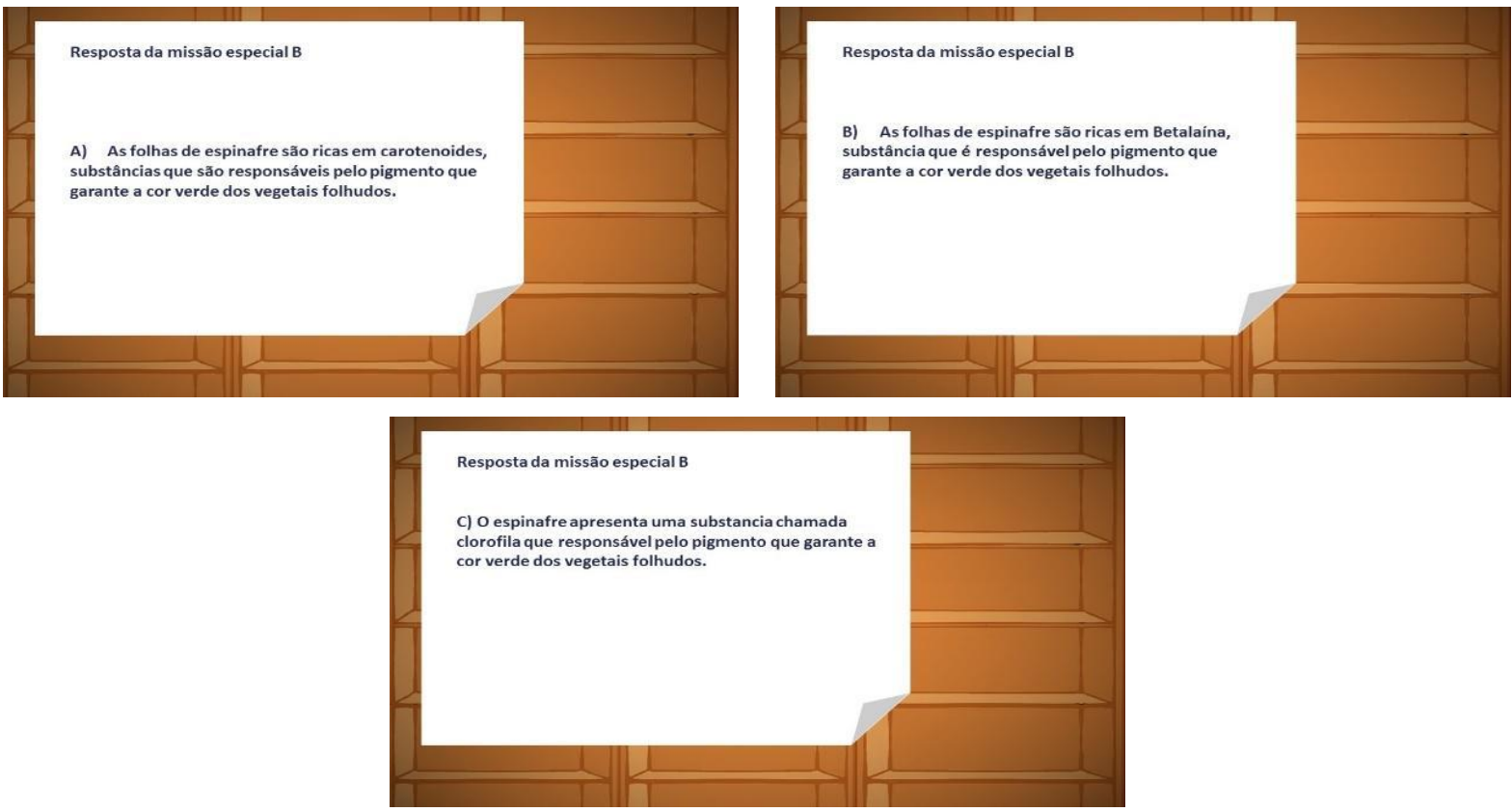

\section{Respostas da pergunta 10}
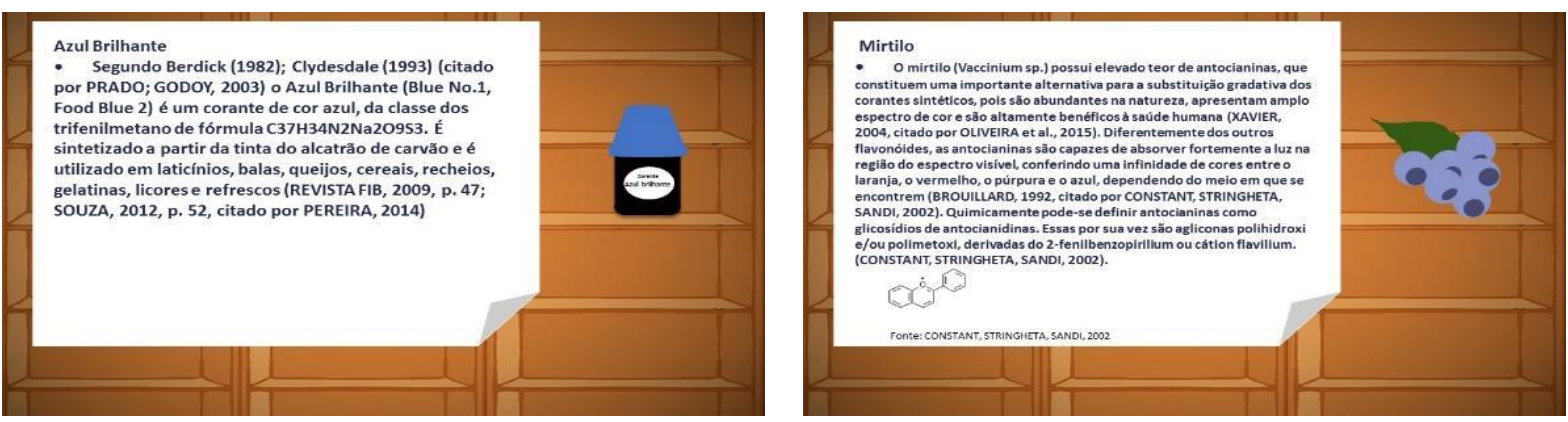


\section{Respostas da pergunta 11}
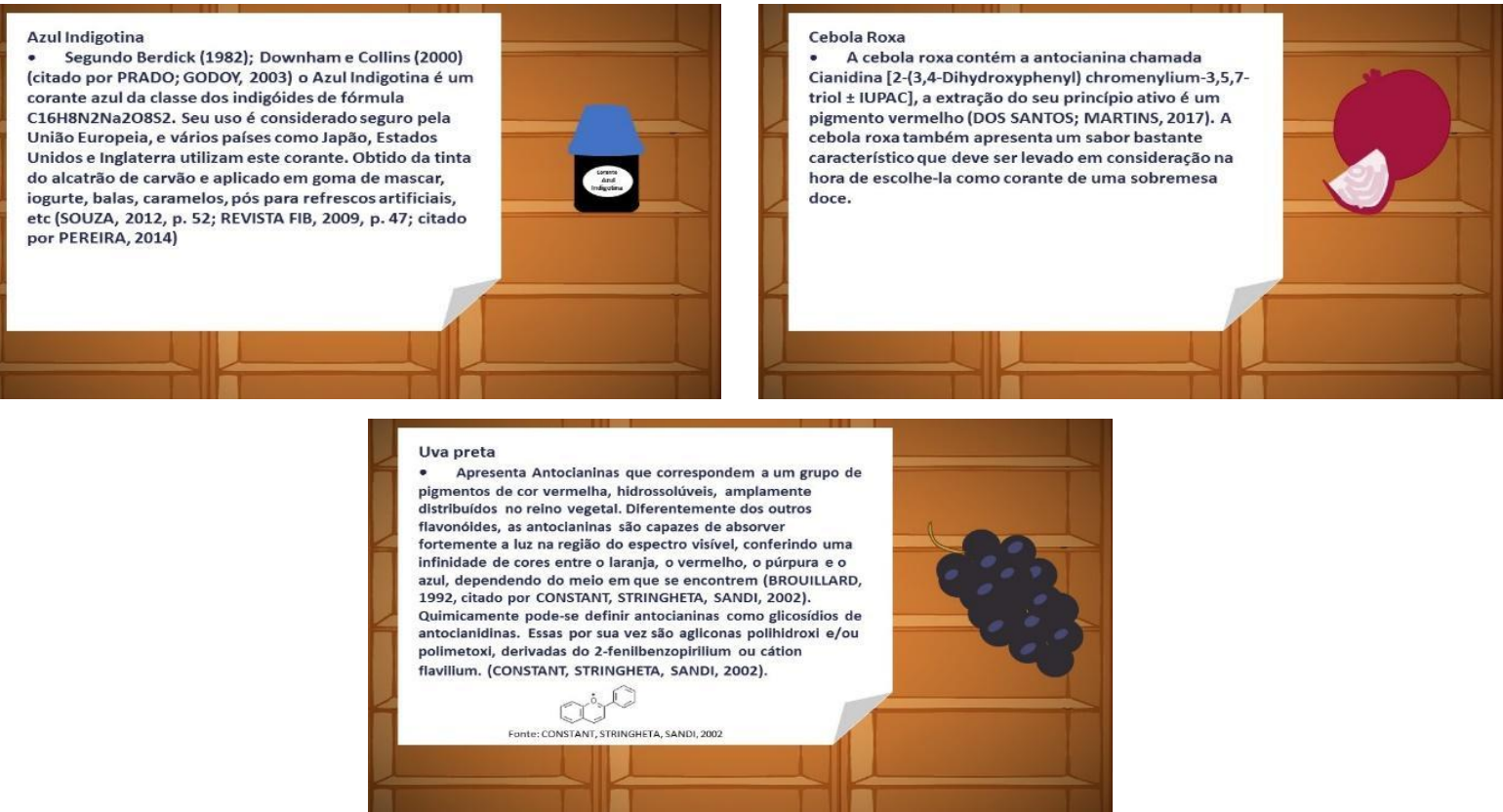


\section{Anexo 3}

\section{Cartas de perguntas estão na ordem cronológica do jogo}

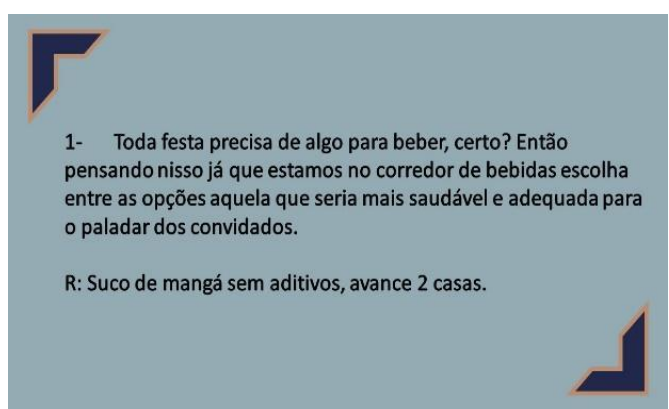

2- Agora no setor das gelatinas, elas são super populares entre as crianças pela consistência molenga e principalmente pelas cores vibrantes. Então pensando nisso esse item não pode faltar na festa escolha entre os três produtos que tem nas prateleiras, pense no item que seria mais saudável e adequado aos convidados.

R: Gelatina Natural de uva, avance 3 casas

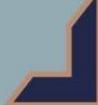

4- Estamos passando por um verão intenso, pensando nisso uma sobremesa gelada seria o ideal para uma festa diurna, aproveite que está no corredor de frios e escolha um sabor de sorvete ideal para uma festa alegre e saudàvel!

R: Sorvete natural de maracujá, cajà e manga, avance 3 casas.
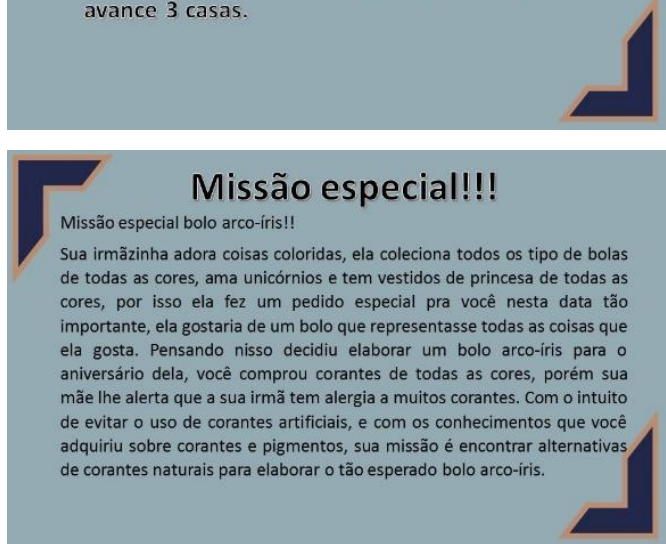

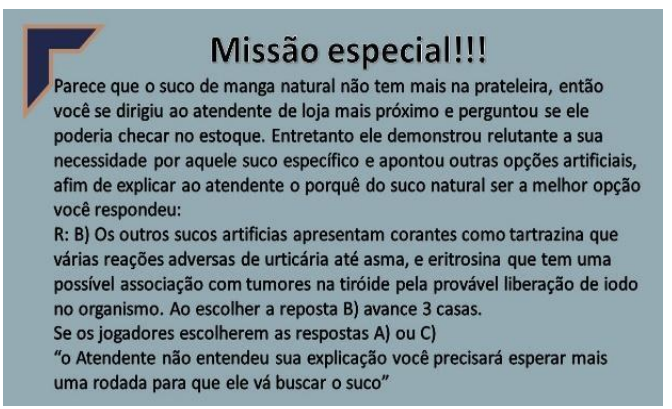

3- Finalmente o setor mais esperado de todos, o setor dos doces e balas. Sempre muito aguardado pela criançada, eles são essenciais em toda comemoração, quase sempre feitos de forma artificial e por isso devemos sempre estar atentos a esse produto. E como você já sabe bastante sobre corantes e está bem informado sobre as alternativas para o uso deles, escolha uma das guloseimas para sua festa.

R:Balas de goma orgânica, avance 3 casas.

5- Você chegou ao corredor de bolachas e biscoitos, eles são um sucesso entre o público infantil, e não importa como você os chama, bolacha ou biscoito, eles combinam muito com o paladar dos principais convidados. Escolha entre os produtos na prateleira aquele mais saudável e nutritivo.

R: Biscoito Amanteigado, avance 4 casas.

- Para a cor vermelha você selecionou:

R: Beterraba, avance 3 casas. 

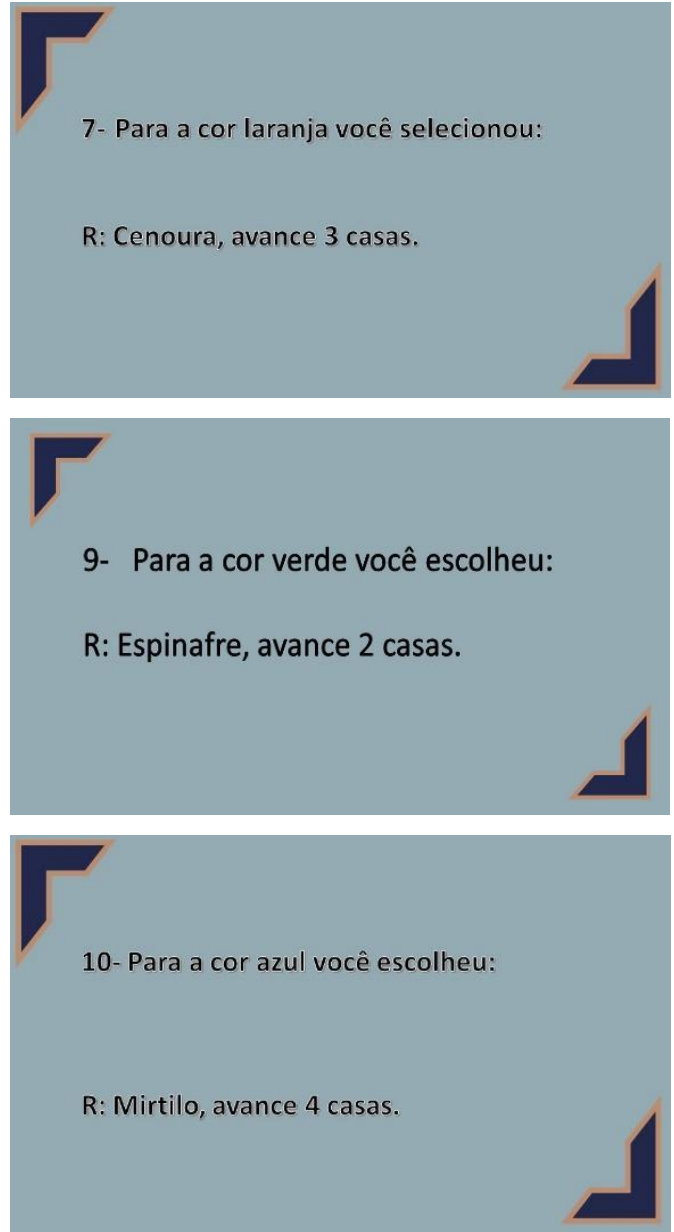
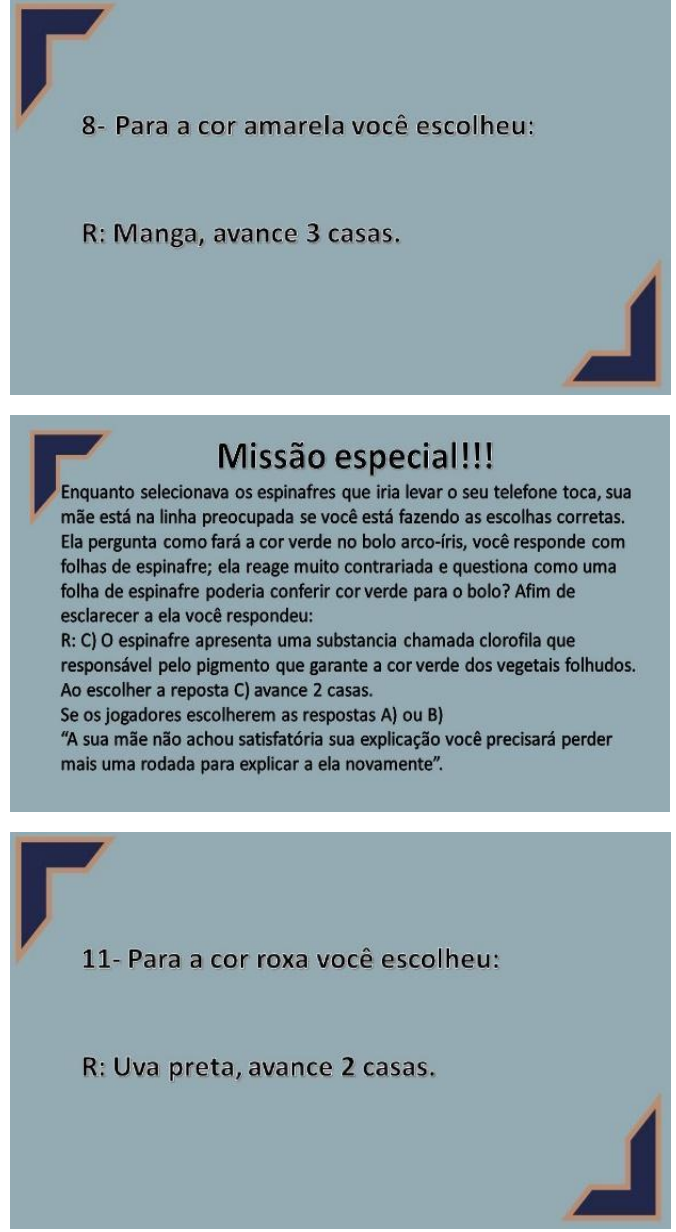


\section{CONCLUSÃO}

O processo de ensino está em constante evolução e cada vez mais busca-se formas de se otimizar o aprendizado dos alunos. Em um passado não tão distante, os métodos de ensino eram engessados, conteudistas e meramente técnicos, um modelo que estava mais preocupado em medir a capacidade dos estudantes de reproduzir um texto decorado do que realmente avaliar seu entendimento sobre o conteúdo.

Atualmente no campo educacional existe uma preocupação cada vez maior em desenvolver métodos didáticos e divertidos, que instiguem os alunos e despertem sua atenção, fazendo com que eles sintam interesse em aprender sobre o tema em estudo. Além disso, esses métodos precisam levar em conta a acessibilidade do conteúdo, trazendo, tanto quanto possível, este conteúdo para a realidade do aluno, demonstrando onde fenômenos estudados em sala, de forma teórica, podem ser vistos em casa, no dia a dia, de forma prática.

Tendo isso em vista, espera-se que ao fim deste jogo, os alunos possam compreender melhor sobre o tema corantes e pigmentos, e que tenham despertado a percepção de como a química pode estar presente em algo tão simples como a cor de um alimento, e como a química é algo palpável, real e presente na vida de todos, algo que pode ser tão simples quanto o mero ato de fazer compras em um supermercado.

\section{REFERÊNCIAS}

[1] BARBOSA, M. I. M. J.; SANTOS, R. B.; CHARÃO, K. S.; SOUTO, R. M.; BARBOSA JÚNIOR, J. L. Desenvolvimento e análise sensorial de gelatina elaborada com frutas liofilizadas. Revista Brasileira de Produtos Agroindustriais, Campina Grande, v. 15, n. 2, p. 129-136, 2013.

[2] CAVALCANTI, E. L. D. SOARES, M. H. F. B. O RPG como estratégia de problematização e avaliação do conhecimento químico. Revista Electrónica de Enseñanza de las Ciencias, 8, 255-280, 2009.

[3] CLEIDE MARIA FERREIRA PINTO; CLÁUDIA LÚCIA DE OLIVEIRA PINTO; SÉRGIO MAURICIO LOPES DONZELES. PIMENTA CAPSICUM: PROPRIEDADES QUÍMICAS, NUTRICIONAIS, FARMACOLÓGICAS E MEDICINAIS E SEU POTENCIAL PARA O AGRONEGÓCIO. Revista Brasileira de Agropecuária Sustentável, [S. l.], v. 3, n. 2, 2013. DOI: 10.21206/rbas.v3i2.225. Disponível em: https://periodicos.ufv.br/rbas/article/view/2816. Acesso em: 25 out. 2020.

[4] CONSTANT, P.B.L; STRINGHETA, P.C; SANDI, D. CORANTES ALIMENTÍCIOS. Curitiba, v.20, n.2, p. 203-220, jul./dez., 2002. Disponível em: <http://revistas.ufpr.br/alimentos/article/view/1248/1048>. Acesso em: 30 de Set. 2020

[5] DOS SANTOS, G.; MARQUES MARTINS, M. CEBOLA ROXA: ANTOCIANINA COMO INDICADOR ÁCIDO-BASE. Anais do Salão Internacional de Ensino, Pesquisa e Extensão, v. 9, n. 2, 3 mar. 2020.

[6] FELÍCIO, Cínthia Maria. Commitment to responsibility playful, playfulness in teaching Chemistry in basic training and professional. 2011. 165 f. Tese (Doutorado em Ciencias Exatas e da Terra) - Universidade Federal de Goiás, Goiânia, 2011. 
[7] FONSECA, S. F.; GONÇALVES, C. C. S. Extração de Pigmentos do Espinafre e Separação em Coluna de Açúcar Comercial. Química Nova na Escola, v. 20, p. 54-58, 2004.

[8] NOGUEIRA MORETES, D.; MATIAS GOMES GERON, V. L. OS BENEFÍCIOS MEDICINAIS DA Curcuma longa L. (AÇAFRÃO DA TERRA). Revista Científica da Faculdade de Educação e Meio Ambiente, [S. l.], v. 10, n. 1, p. 106-114, 2019. DOI: 10.31072/rcf.v10iedesp.767. Disponível em: http://www.faema.edu.br/revistas/index.php/Revista-FAEMA/article/view/767. Acesso em: 25 out. 2020.

[9] OLIVEIRA, T. P.; PANTE, G. C.; TOSONI, N. F.; SEREIA, M. J.; JÚNIOR, B. D. Caracterização e aplicação da polpa de mirtilo (Vaccinium sp.) in natura e em pó em frozen yogurt. Brazilian Journal of Food Research, v. 6, n.3, p.23-31, 2015.

[10] PEREIRA, Gabriela Aparecida de Araujo. Pesquisa de Corantes Orgânicos Artificiais em Bebidas Não Alcoólicas dos tipos Suco, Néctar e Refresco. 2014. $131 \mathrm{f}$. TCC (Graduação) - Curso de Bacharelado em Química Industrial, Fundação Educacional do Município de Assis, Assis-Sp, 2014. Disponível em: https://cepein.femanet.com.br/BDigital/arqTccs/1111360100.pdf. Acesso em: 03 out. 2020.

[11] RODELLA, F. M.; SOUZA, S. M. B. de. Extração de corante natural. Disponível em: < https://cepein.femanet.com.br/BDigital/arqPIBIC/1211360043B504.pdf> Acesso em 05 de Out de 2020.

[12] SOUZA, Rosilane Moreth; Corantes Naturais Alimentícios e Seus Benefícios a Saúde. 2012, 65 p. Trabalho de Conclusão de Curso apresentado ao Curso de Graduação em Farmácia da UEZO, como parte dos requisitos para a obtenção do grau de Bacharel em Farmácia. Rio de Janeiro, Rio de Janeiro, 2012.

[13] TOLEDO, Elizete da Aparecida. O RPG como estratégia de ensino: uma proposta para o ensino de profissões. Guarapuava, PDE, 2015.

[14] TONIAL, I. B.; SILVA, E. L. A química dos corantes naturais: Uma alternativa para o ensino de química. UEM - Universidade Estadual de Maringá, 2008. Disponível em: < http://www.diaadiaeducacao.pr.gov.br/portals/pde/arquivos/2160-8> Acesso dia 25 de Out. de 2020. 


\section{Jogo 2}

Verdadeiro ou falso, a verdade sobre corantes e pigmentos

João Vitor Araújo Souza

Layonara Dhuly da Silva Teixeira

Maria da Conceição Tavares Cavalcanti Liberato 


\section{INTRODUÇÃO}

Os alimentos podem ser coloridos de maneira natural, através de pigmentos naturais intrínsecos ou não a sua estrutura ou por meio do acréscimo de corantes sintéticos durante sua produção, industrialização ou processamento (ROCHA e REED, 2014; CONSTANT; STRINGHETA e SANDI, 2002).

As cores dos alimentos têm relação direta com a atração do consumidor, pois, em um primeiro momento, o impacto visual tem grande influência no processo de escolha de um alimento. Portanto, é comum a adição de pigmentos artificiais em alimentos que sofrem algum tipo de processo industrial. Esses aditivos podem ser aplicados para colorir ou reforçar a cor de um alimento, para o tornar visualmente agradável (CONSTANT; STRINGHETA e SANDI, 2002).

A diversidade de cores presentes nas plantas é promovida por pigmentos naturais. As classes mais relevantes desses pigmentos são: clorofila, carotenóide e flavonóide, enquanto a betalaína, a melanina e outros tipos de pigmentos não se apresentam de maneira tão significativa quando se analisa as representações em grande escala (SCHIOZER e BARATA, 2013).

Os corantes artificiais são aditivos que não apresentam valores nutritivos e este fato levanta questionamentos a respeito da sua utilização. A aplicação desses produtos acontece apenas por questões estéticas que envolvem hábitos alimentares, pois a aceitabilidade dos alimentos está relacionada a sua aparência (RIEDEL, 1987; PRADO e GODOY, 2009).

No entanto, alguns efeitos maléficos à saúde estão relacionados com o uso de corantes sintéticos, como é o caso de algumas alergias. Então, atualmente, a aplicação desses aditivos tem sido uma pauta de destaque, pois as opiniões sobre o assunto são diversas. Isso pode ser visualizado através da permissividade das quantidades e dos tipos de corantes permitidos para uso em alimentos, que varia a depender do país ou da região (PRADO e GODOY, 2009).

Desta maneira, entender a presença, a composição e os riscos de corantes e pigmentos nos alimentos que se consome é de suma importância para uma alimentação saudável. Descubra verdades e desvende as mentiras escondidas sobre esses aditivos alimentares com o jogo Verdadeiro ou Falso.

\section{INSTRUÇÕES}

0 jogo consiste em uma atividade de perguntas e respostas, podendo ser jogado por dois ou mais jogadores. Ele é composto de um conjunto de 20 cartas, cada uma tem uma afirmação, elas devem ser lidas para o jogador do turno e ele deve responder se essa afirmação é verdadeira ou falsa, se acertar ele ganha um ponto e passa para o próximo jogador; se errar ele não ganha nenhum ponto e passa a vez. Quem possuir mais pontos no final vence. 

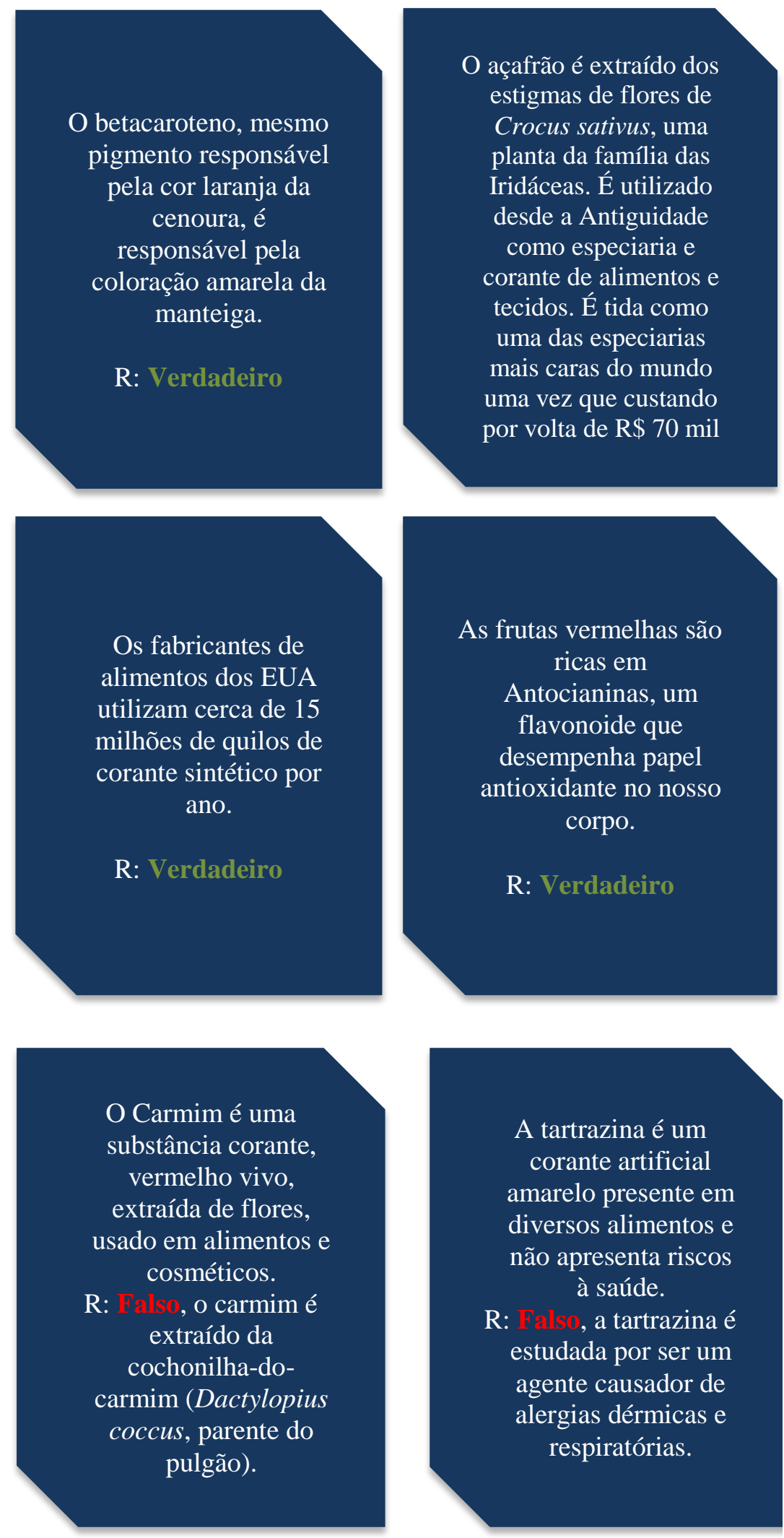

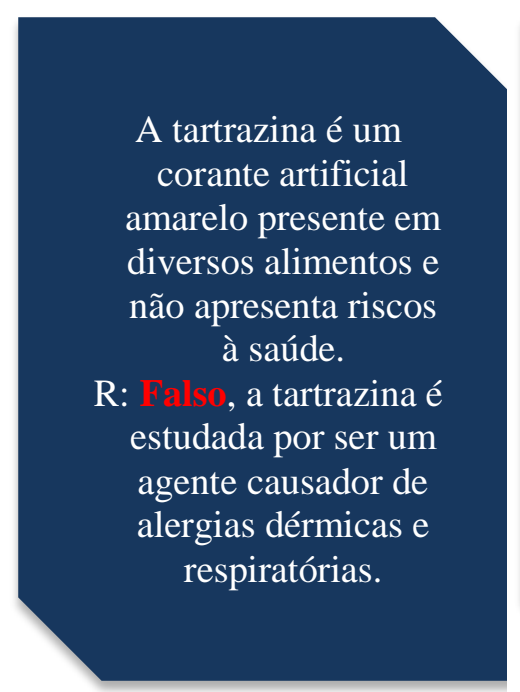

Sempre devemos optar por corantes artificiais já que eles são inofensivos a nossa saúde.

R: Falso, os corantes artificiais podem apresentar alta toxicidade ao nosso corpo assim devemos sempre preferir os pigmentos naturais. 
O licopeno é uma substância artificial aplicada em alimentos como corante vermelho. R: Falso, o licopeno é uma substância natural, esse pigmento está presente no tomate, melancia e goiaba e pode substituir o Carmim.
O Carmim não é um pigmento natural.

R: Falso, o carmim é um pigmento natural extraído de insetos.
Os corantes do grupo

AZO são

caracterizados a

partir de uma dupla

ligação entre os

carbonos.

R: Falso, os azo-

compostos referem-

se a compostos

químicos que

carregam o grupo

funcional $\mathrm{R}-\mathrm{N}=\mathrm{N}-\mathrm{R}$ '.
O uso de agentes colorantes em alimentos só foi difundido depois da segunda guerra. R: Falso, o uso de colorantes é datado desde o início da civilização, utilizando agentes vegetais para colorir alimentos.

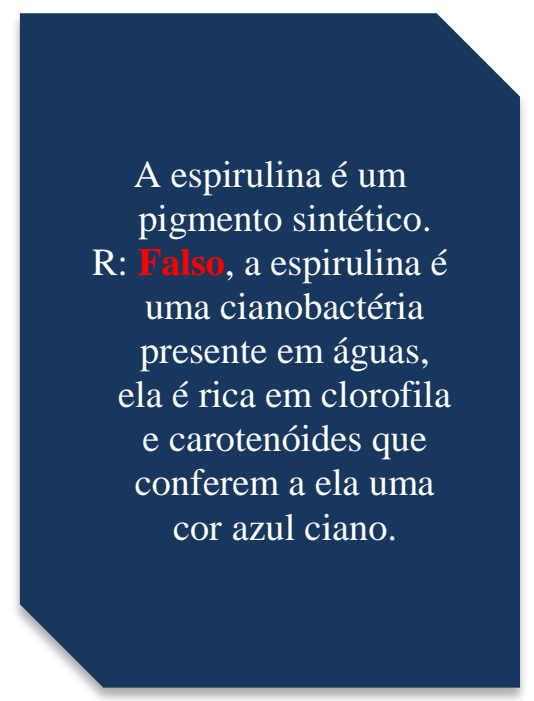

Todos os corantes caramelo são naturais.

R: Falso, o corante caramelo foi obtido através do processo de caramelização do açúcar, através da reação de Maillard esse processo é natural e muito usado, e é o menos nocivo. Porém, o corante caramelo pode ser obtido através da reação entre açúcares

e amônia/sulfitos, de forma sintética e podendo ser nociva à saúde. 


\section{REFERÊNCIAS}

[1] ARAÚJO, J. M. A. Química dos Alimentos- Teoria e Prática. 4ª ed. Viçosa, MG: Ed. UFV, 2008. 596p.

[2] CARDOSO, S, L. FOTOFÍSICA DE CAROTENÓIDES E O PAPEL ANTIOXIDANTE DE $\beta$-CAROTENO. Química Nova, [s. l], v. 20, n. 5, p. 535-540, 1997.

[3] CONSTANT, P. B. L.; STRINGHETA, P. C.; SANDI, D. Corantes alimentícios. Boletim do Centro de Pesquisa de Processamento de Alimentos, v. 20, n. 2, 2002.

[4] COUlTATE, T. P. Alimentos: A química de seus componentes. $3^{\mathfrak{a}}$ ed. Porto Alegre: Artmed, 2004. 368p.

[5] CRIZEL, R. L. Prospecção de pigmentos produzidos por cochonilhas Ceroplastesspp. para aplicação em alimentos. 2017. 62 f. Dissertação (Mestrado) Curso de Ciência e Tecnologia de Alimentos, Universidade Federal de Pelotas, Pelotas, 2017.

[6] DAMODARAN, S.; PARKIN, K. L.; FENNEMA, O. R. Química de Alimentos de Fennema. $4^{\mathrm{a}}$ ed. Porto Alegre: Artmed, 2010. 900p.

[7] FABRI, E. G.; TERAMOTO, J. R. S. Urucum: fonte de corantes naturais. Horticultura Brasileira, [S.L.], v. 33, n. 1, p. 140-140, mar. 2015. FapUNIFESP (SciELO). http://dx.doi.org/10.1590/s0102-053620150000100023.

[8] INSTITUTO BRASILEIRO DE DEFESA DO CONSUMIDOR. Você sabe o que é Caramelo IV? Disponível em: https://idec.org.br/consultas/dicas-e-direitos/voce-sabeo-que-e-caramelo-iv. Acesso em: 05 out. 2012.

[9] LOPES, R. M.; OLIVEIRA, T. T. de; NAGEM, T. J.; PINTO, A. da S. Farmacologia de flavonóides no controle hiperlipidêmico em animais experimentais. Biotecnologia Ciência \& Desenvolvimento, [s. l], v.17, p. 18-22, 2000.

[10] MUCCIOLO, P.; BARBUTO, O.; CAMPOS, M. M. TEOR DE VITAMINA A E CAROTENO EM MANTEIGAS CONSUMIDAS EM SÃO PAULO. Rev. Fac. Med. Vet., São Paulo, v. 5, n. 3, p. 551-561, 1995.

[11] OLIVEIRA, V. P. de; ESPESCHIT, A. C. R.; PELUZIO, M. do C. G. FLAVONÓIDES E DOENÇAS CARDIOVASCULARES: AÇÃO ANTIOXIDANTE. Rev Med Minas Gerais, [s. l], v. 16, n. 4, p. 234-238, 2006.

[12] PRADO, M. A.; GODOY, H. T. Corantes artificiais em alimentos. Alimentos e Nutrição Araraquara, v. 14, n. 2, 2009.

[13] RIEDEL, G. Controle sanitário dos alimentos, São Paulo: Loyola, 1987. 445 p

[14] ROCHA, D. S.; REED, E. Pigmentos Naturais em Alimentos e sua Importância para a Saúde. Revista EVS-Revista de Ciências Ambientais e Saúde, v. 41, n. 1, p. 76-85, 2014. 
[15] SCHIOZER, A. L.; BARATA, L. E. S. Estabilidade de Corantes e Pigmentos de Origem Vegetal. Revista Fitos, [S.l.], v. 3, n. 02, p. 6-24, 2013.

[16] SILVA, A. P. da; LIMA, C.L.C. de; VIEITES, R. L. CARACTERIZAÇÃO QUÍMICA E FÍSICA DO JENIPAPO (Genipa americana L.) ARMAZENADO. Scientia Agricola, [S.L.], v. 55, n. 1, p. 29-34, jan. 1998. FapUNIFESP (SciELO). http://dx.doi.org/10.1590/s010390161998000100006.

[17] STREIT, N. M.; CANTERLE, L. P.; CANTO, M. W. do; HECKTHEUER, L. H. H. As clorofilas. Ciência Rural, [S.L.], v. 35, n. 3, p. 748-755, jun. 2005. FapUNIFESP (SciELO). http://dx.doi.org/10.1590/s0103-84782005000300043.

[18] TEIXEIRA, L. V. ANÁLISE SENSORIAL NA INDÚSTRIA DE ALIMENTOS. Rev. Inst. Latic, [s. l], v. 366, n. 64, p. 12-21, 2009. 


\section{Jogo 3}

\section{Você conhece as BETALAÍNAS?}

Vitor Rocha de Carvalho

Maria da Conceição Tavares Cavalcanti Liberato 


\section{INTRODUÇÃO}

Atualmente o ensino de química vem se modificando, principalmente no curso de licenciatura, na parte de criação de projetos pedagógicos, facilitando tanto o entendimento dos discentes na faculdade, quanto a transmissão de conhecimento para seus futuros alunos. A produção de materiais didáticos, segundo Miranda (2002), incluindo jogos, encorajam a participação e o interesse dos alunos inserindo dinamismo e entusiasmo nas aulas e nos conteúdos abordados pelos professores.

0 jogo consiste em aumentar o interesse sobre corantes presentes em alguns alimentos, em especial as betalaínas, que são corantes presentes na beterraba e na pitaya, entre os alunos do ensino médio e da faculdade de química e nutrição da cadeira de química de alimentos.

\section{MATERIAL}

Composto por 1 tabuleiro,2 dados, peões que irão representar cada um dos jogadores, cartões com as questões e cartões com a estrutura dos principais compostos.

\section{OBJETIVO DO JOGO}

Demonstrar como os corantes naturais estão presentes no nosso dia a dia, através dos alimentos, facilitando a aprendizagem do conteúdo. Além de revisar o conteúdo já aplicado em sala de aula, de uma forma mais descontraída, contextualizando o conteúdo aprendido em sala com o dia a dia do aluno.

Dentro do jogo, a forma de obter a pontuação do jogo seria obter o maior número de pontos ao passar pela primeira casa (casa início), durante um tempo preestabelecido.

\section{REGRAS GERAIS}

1. Os participantes devem escolher seu peão e para começar cada um deve jogar os dados. 0 que tirar o maior número começa.

2. Cada quadrinho é uma unidade e cada vez que o participante passa por lá ele responde uma pergunta e algumas unidades, no lugar de responder a pergunta terá uma atividade diferente.

3. As cartas de questões devem ser embaralhadas antes de começar a partida.

4. Cada participante vai responder a pergunta e se errar deve retornar o número de casas que retirou nos dados.

5. Caso o participante não saiba responder a primeira pergunta, retornará para a primeira casa (casa início).

6. Cada vez que você retorna a primeira casa após completar uma volta, você ganha 1 ponto.

7. Se depois da primeira volta, caso o participante não souber responder a pergunta, ele perde o ponto que ganhou na rodada anterior. 
8. Caso o participante erre a questão, qualquer um dos outros participantes pode se candidatar a responder, e se acertar deve avançar três casas e caso erre deve retornar uma casa.

9. Depois que o participante responde a pergunta, independente de acertar ou não, o que se segue é o que está à esquerda.

10. No tabuleiro, terá algumas casas como tarefas diferentes*. As tarefas diferentes, serão descritas em seguida.

11. As cartas estrutura química e perguntas devem ser embaralhadas e colocadas na área demarcadas no tabuleiro para serem utilizadas durante o jogo.

\section{TAREFAS DIFERENTES}

1. Estrutura Química: Nesse caso, é a identificação de funções orgânicas da estrutura e será feita a partir das imagens presentes nos cartões, sem o uso de livros e o professor, deve indicar se essa função está presente. Nesse caso, o ponto será contabilizado se o participante acertar o maior número das funções.

2. Ajuda usando o livro: 0 participante não poderá pedir ajuda a outro participante, e terá o tempo de 1 minuto para consultar as anotações feitas nas aulas teóricas aplicadas em sala. Caso ele acerte, avançará o número de casas que foi tirado nos dados e caso erre, deve retornar duas casas.

3. Ajuda coletiva: Nesta opção, os outros participantes podem ajudar a responder a pergunta, mas não podem consultar o material de apoio. (Essa opção não é válida para a tarefa estrutura química.) 
Figura 1:Tabuleiro

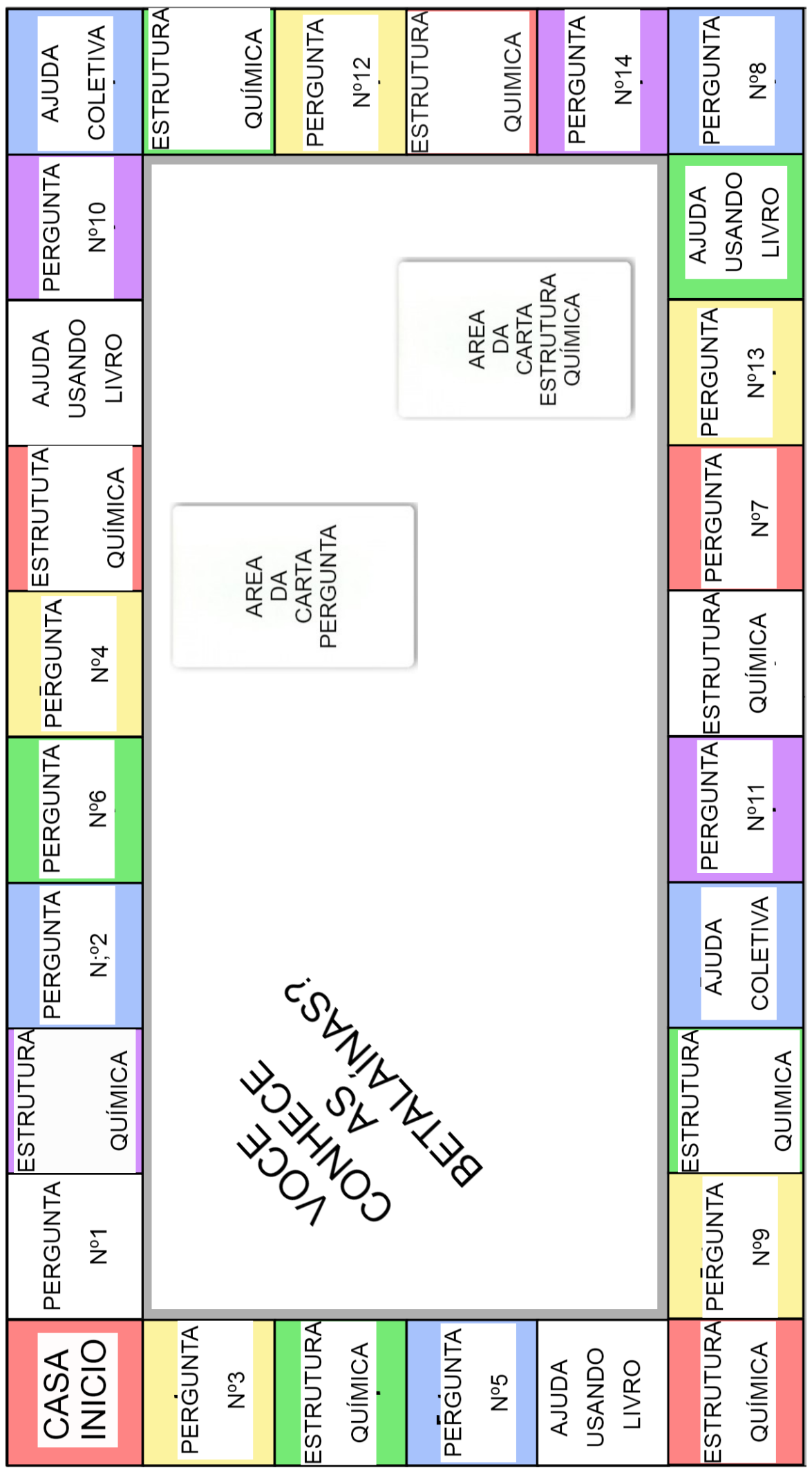


- Cartas

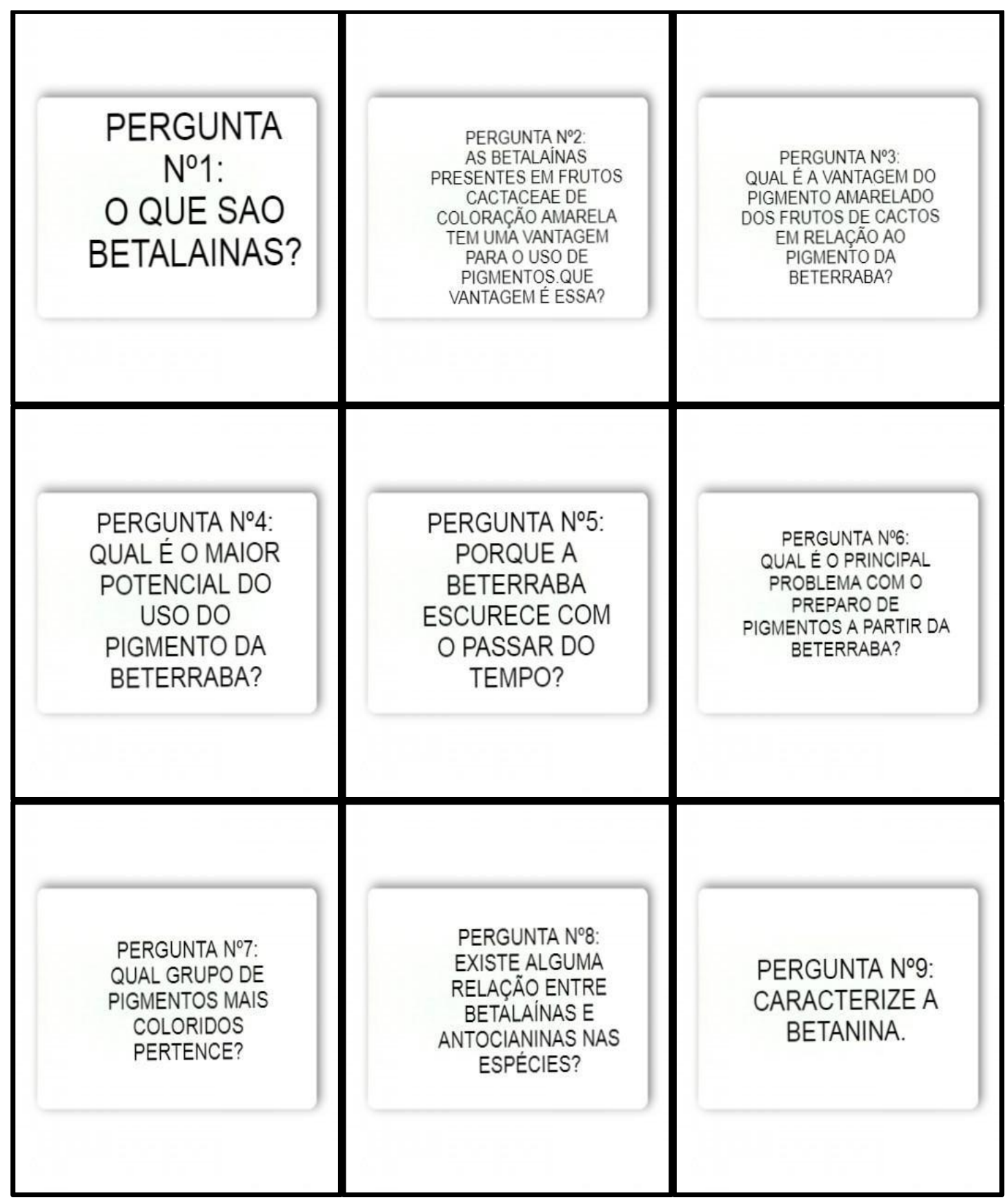




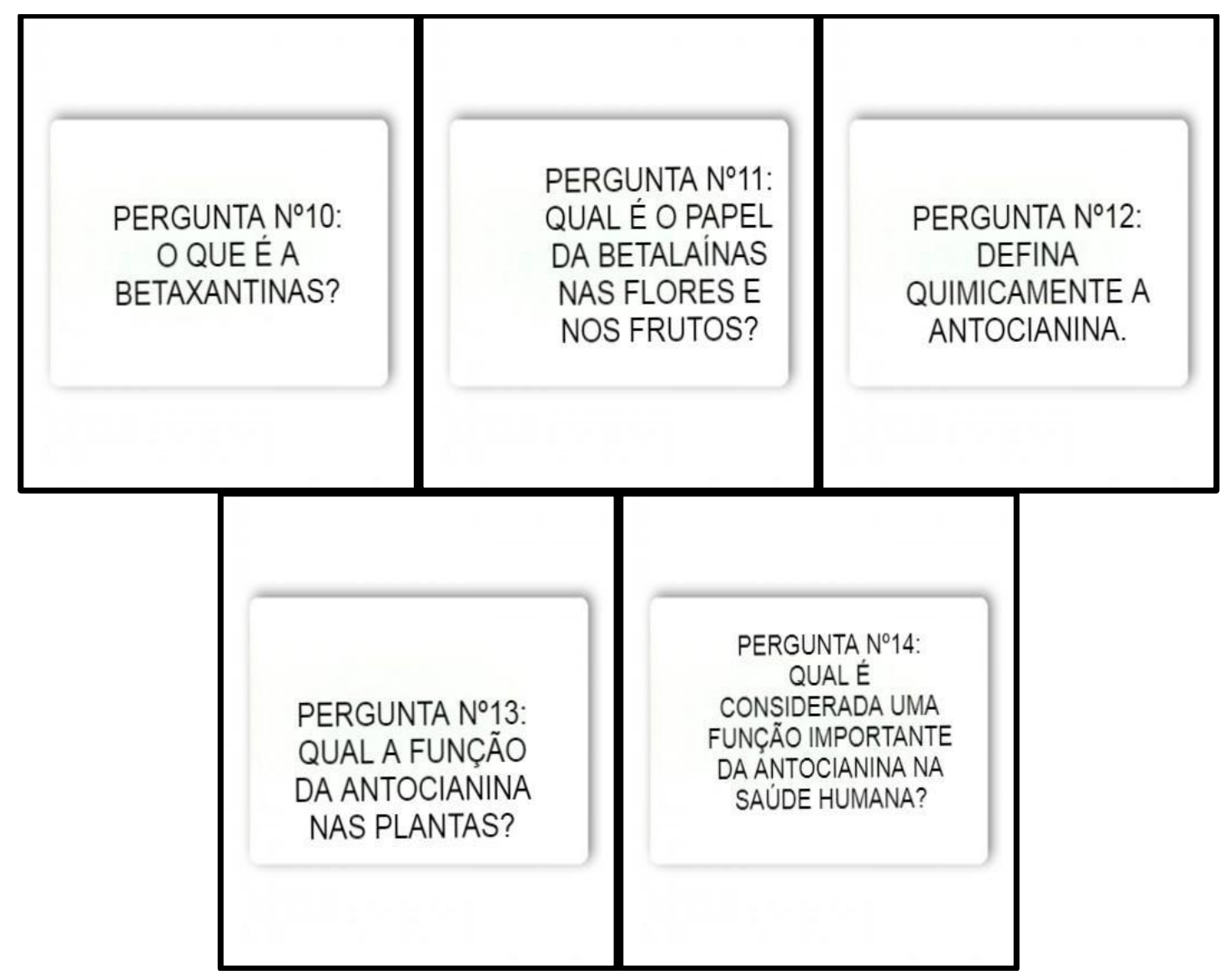


- Cartas Estruturas Químicas

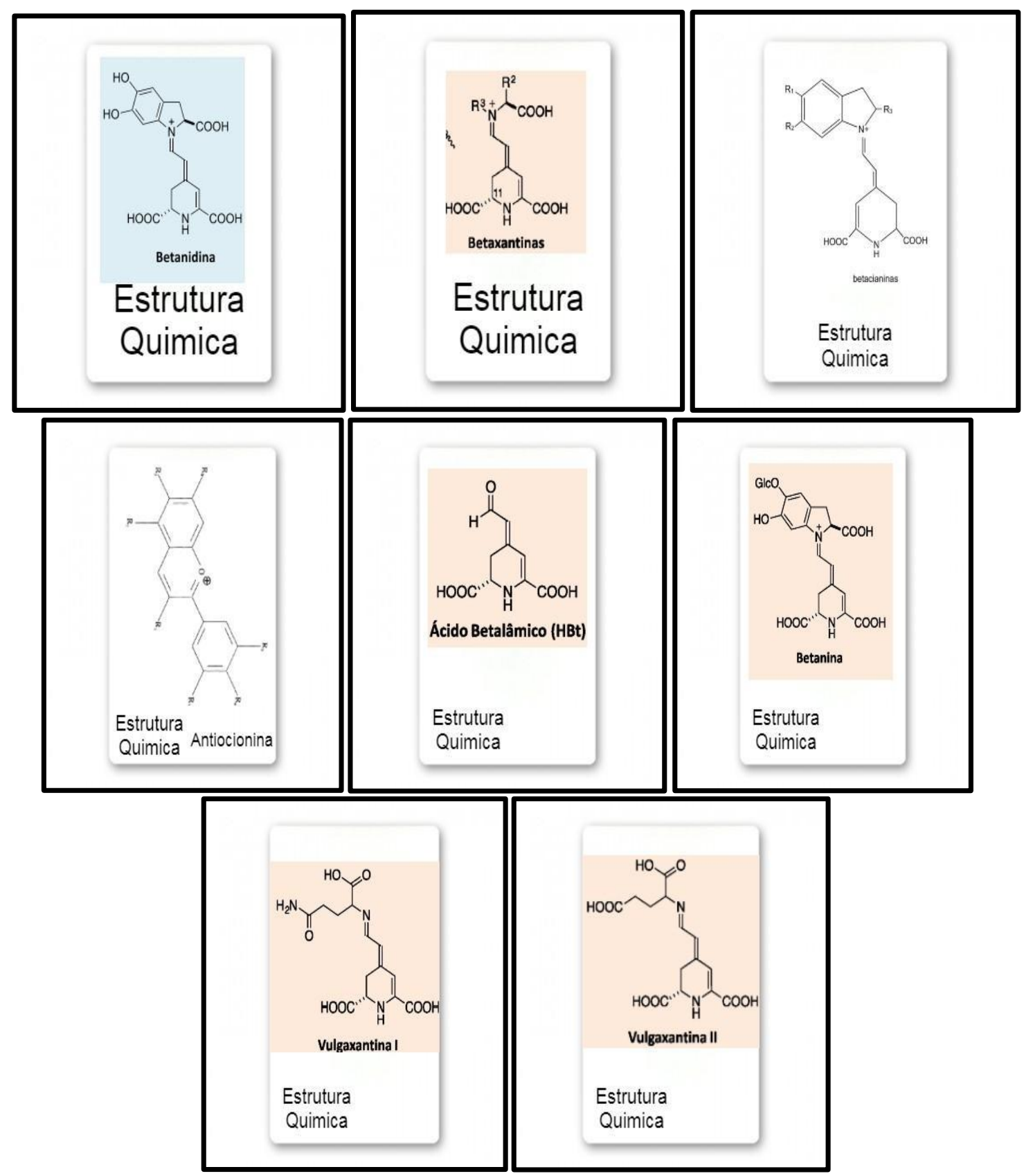




\section{PERGUNTAS}

\section{0 que são betalaínas?}

Resposta: Betalaínas são alcalóides coloridos, atóxicos e solúveis em água que substituem as antocianinas em todas as famílias de plantas da Ordem Caryophyllales, exceto nas famílias Caryophyllaceae e Molluginaceae.

\section{As betalaínas presentes em frutos cactaceae de coloração amarela tem uma} vantagem para o uso de pigmentos. Que vantagem é essa?

Resposta: As variedades amarelas destas frutas são de grande interesse, já que pigmentos naturais amarelos solúveis em água são pouco abundantes. Ainda, estas plantas podem ser cultivadas em regiões áridas e semiáridas, o que é uma grande vantagem em termos de economia agrícola.

3.Qual é a vantagem do pigmento amarelado dos frutos de cactos em relação ao pigmento da beterraba?

Resposta: Níveis reduzidos de nitrato no pigmento amarelo da fruta do cacto aumentam sua aplicabilidade em alimentos no lugar de extrato de beterraba.

\section{Qual é o maior potencial do uso do pigmento da beterraba?}

Resposta: 0 uso da beterraba amarela é fornecer betaxantinas para a composição de misturas com betacianinas de beterraba vermelha de forma a aumentar a gama de cores para aplicação.

\section{Porque a beterraba escurece com o passar do tempo?}

Resposta: Beterrabas são sujeitas ao escurecimento graças à presença de polifenol oxidases, e preparações de beterrabas douradas acabam se tornando pouco atraentes já que seu escurecimento é mais aparente do que nas variedades vermelhas.

\section{Qual é o principal problema com o preparo de pigmentos a partir da beterraba?}

Resposta: 0 seu alto nível de nitrato e seu cheiro desagradável de terra causado pela presença de derivados pirazolínicos e geosmina.

\section{Qual grupo de pigmentos mais coloridos pertence?}

Resposta: Os pigmentos mais comuns colorindo as flores, folhas, frutos e sementes das Angiospermas são os flavonoides, em especial as antocianinas. 


\section{Existe alguma relação entre betalaínas e antocianinas nas espécies?}

Resposta: Nas espécies que produzem betalaínas não são encontradas antocianinas e nas poucas famílias pigmentadas por antocianinas (Molluginaceae e Caryophyllaceae) não se encontram betalaínas.

\section{Caracterize a betanina.}

Resposta: A betanina, também conhecida como $\beta$ nina ou vermelho beterraba, é um glicosídeo de cor vermelha oriundo da beterraba (Beta vulgaris) e é usado como corante alimentar (E162). O seu grupo aglicona é a betanidina. A betanina é normalmente obtida a partir do extracto de beterraba vermelha; a sua concentração pode atingir os 300-600 mg kg-1. Tem fórmula molecular $\mathrm{C}_{24} \mathrm{H}_{26} \mathrm{~N}_{2} \mathrm{O}_{13}$ e massa molar $550,47 \mathrm{~g} \mathrm{~mol}^{-1}$; É um pigmento pertencente à classe das betalaínas, juntamente com a isobetanina, a probetanina e a neobetanina; A betanina sofre degradação com o calor, luz e exposição a oxigênio. É por esta razão que é usada principalmente como corante em alimentos congelados, em alimentos com período de validade curto.

\section{0 que é a betaxantinas?}

Resposta: Betaxantinas (Latim: beta = beterraba; Grego: xanthos = amarelo) são iminas ou sais de imínio com máximo de absorção entre 460 e $480 \mathrm{~nm}$ e que se originam do acoplamento entre o ácido betalâmico e aminoácidos.

\section{Qual é o papel das betalaínas nas flores e nos frutos?}

Resposta: 0 papel das betalaínas em flores e frutos parece relacionar-se com a atração de vetores no processo de polinização e dispersão de sementes. No entanto, as vantagens evolutivas da presença de betalaínas em órgãos vegetativos e em fungos superiores ainda são desconhecidas.

\section{Defina quimicamente a antocianina.}

Resposta: Quimicamente, esses pigmentos são compostos fenólicos pertencentes ao grupo dos flavonóides, grupo de pigmentos naturais amplamente distribuídos no reino vegetal.

\section{Qual a função da antocianina nas plantas?}

Resposta: Entre as muitas funções que possuem está a atração de polinizadores de sementes, proteção contra danos provocados pela luz UV na folha, atuando como filtro e melhorando e regulando a fotossíntese.

14.Qual é considerada uma função importante da antocianina na saúde humana?

Resposta: As antocianinas apresentam grande importância na dieta humana podendo ser considerada como uma importante aliada na prevenção/retardamento 
de doenças cardiovasculares, do câncer e doenças neurodegenerativas, devido ao seu poder antioxidante, atuando contra os radicais livres, apresentando propriedades farmacológicas sendo utilizadas para fins terapêuticos.

\section{REFERÊNCIAS}

[1] MIRANDA, Simão de. Do fascínio do jogo à alegria do aprender. Linhas Críticas, Brasília, v. 8, n. 14, p. 21-34, jun. 2002. 


\section{Jogo 4}

\section{Duelo}

João Vitor Araújo Souza

Layonara Dhuly da Silva Teixeira

Maria da Conceição Tavares Cavalcanti Liberato 


\section{INTRODUÇÃO}

Os compostos corantes e de pigmentação estão presentes na vida humana diariamente, seja nos alimentos, nas roupas e até no corpo humano. Sua presença confere benefícios ou malefícios ao alimento devido a suas propriedades químicas. Alimentos industrializados tendem a possuir quantidades exageradas de corantes artificiais, derivados de matéria mineral ou produtos de reações químicas, essas substâncias possuem caráter tóxico apesar de serem aceitas pela legislação (FERREIRA et al., 2018; PEIXOTO, MARINHO e RODRIGUES, 2013).

Os pigmentos naturais, presentes em produtos naturais e extraídos deles, possuem ação semelhante, um pouco mais sensíveis a fatores externos como calor e $\mathrm{pH}$, entretanto, eles fornecem benefícios ao seu consumo, por muitos possuírem ação antioxidante, anti inflamatória, dentre outras (HAMERSKI, REZENDE e DA SILVA,2013).

Desta forma, possibilitar ao indivíduo observar as propriedades de cada substância colorante alimento é permitir que ele desenvolva consciência na alimentação e dos efeitos dos alimentos em sua saúde.

Assim, nesse jogo desafiador, você receberá dicas sobre compostos que possuem a capacidade de dar cor às coisas que compõem o nosso dia a dia e irá observar suas propriedades e curiosidades, aprimorando seu conhecimento e consequentemente sua alimentação. Será que você conseguirá descobrir quem eles são?

\section{INSTRUÇÕES DO JOGO}

- Os jogadores deverão se dividir em dois grupos ou duplas (a depender da quantidade de jogadores).

- A cada rodada um jogador da equipe 1 deverá ler as dicas de uma carta para um jogador da equipe 2 e vice-versa.

- As dicas da carta estão numeradas de 1 a 5 e deverão ser lidas em ordem.

- Se o jogador acertar o composto da carta com apenas uma dica ele ganha 5 pontos.

- A pontuação da carta vai diminuindo em 1 ponto a cada dica.

- Se o jogador só acertar o composto na leitura da última dica ele ganha apenas um (1) ponto.

- Se ele não acertar não haverá ganho de nenhum ponto.

- Ao final de 4 rodadas os pontos deverão ser contados e a equipe com maior pontuação vence. 


\section{Cartas}

\section{Betacaroteno}

1. É um pigmento carotenoide.

2. É um importante antioxidante.

3. Umas de suas principais fontes são: damasco, cenoura e abóbora.

4. A ingestão em excesso pode ocasionar o aparecimento de uma coloração amarelada na pele.

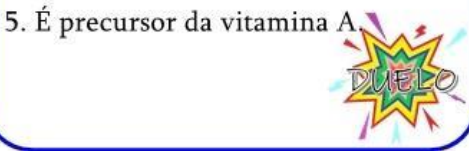

\section{Jenipapo}

1. É um fruto

2. É nativo da floresta amazônica e da mata atlântica.

3. Em guarani seu nome quer dizer "fruta que serve para pintar".

4. É usado pelo índigenas para pintura corporal.

5. Dele é possível extrair pigmento azul.

\section{Licopeno}

1. Pertence à classe dos carotenóides.

2. Está presente no plasma humano.

3. Tem grande potencial antioxidante.

4. Pode ser encontrado como

suplemento alimentar.

5. Responsável pela cor vermelha do tomate,melancia e outros alimentos.

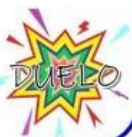

\section{Anfocianinas}

1. Maior classe de substâncias coloridas do reino vegetal.

2. Pertence ao grupo dos flavonoides.

3. São encontrados em muitas frutas escuras como o açaí, framboesa, amora.

4. Pode apresentar uma infinidade de cores entre o laranja, o vermelho, o púrpura e o azul.

5. São os responsáveis pela cor "bordô" do vinho tinto jovem.

\section{Tarfirazina}

1. Presente em bebidas, doces e diversos alimentos ultraprocessados.

2. Oriunda do creosoto mineral, um produto do carvão mineral e tem atividade cancerígena.

3. Também conhecida como E102.

4.Possui a cor amarelo-limão, também é bastante usada com outros corantes para obter colorações diferentes.

5. Seu nome é iniciado com a $~=$ letra $\mathrm{T}$.

\section{Beterraba}

1. É uma planta herbácea.

2. É rica em ferro.

3. Seu pigmento apresenta tom avermelhado.

4. A betalaína é o composto responsável por sua coloração.

5. É associada à origem do bolo Red Velvet.

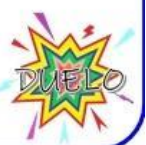

\section{carmilm}

1. A produção deste corante é muito importante para a economia peruana.

2. Sua coloração é um vermelho vivo.

3. Extraído a partir de fêmeas dissecadas de insetos da espécie Dactylopius coccus Costa.

4. É denominada cochonilha a substância responsável pelo potencial tintorial do corante.

5. É produzido a partir da reação da formação de complexos entre -

o ferro e o ácido carmínico.

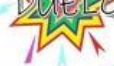

\section{Azul Brillhanies FCF}

1. Também chamado de E133.

2. É produzido a partir de refinamentos de hidrocarbonetos aromáticos oriundos do petróleo.

3. Está na composição de picolés, doces, bebidas.

4. Comum por causar irritações cutâneas e constrição brônquica, além de potencial cancerígeno. Foi banido em vários países europeus.

5. Responsável pela coloração azul de alimentos industrializados.

\section{Uracam}

1. Se apresenta na forma de sementes.

2. É um pigmento natural.

3. Comum na cultura indígena.

4. Possui a coloração vermelha e seu nome origina-se do tupi, que significa "vermelho".

5. Na sua forma como condimento em pó se apresenta como Colorau. 


\section{Caramelo Naturall}

1. Fruto da reação de açúcares.

2. Sua coloração é de amarelo a castanho.

3. Decorrente da reação de Maillard.

4. É um método conhecido desde a idade média.

5. A sua produção é chamada de caramelização.

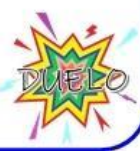

\section{Hemoglobina}

1. É uma proteína.

\section{Pode ser encontrada no corpo} humano.

3. Atua no transporte de gases pelo corpo.

4. Seu átomo central é o ferro.

5. Responsável por dar a coloração vermelha do sangue.

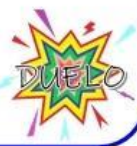

\section{Caramello Artifficial}

1. Fruto da reação de açúcares.

2. Sua coloração é de amarelo à castanho.

3. Presente em bebidas e doces.

4. Essa reação é decorrente da adição de ácidos e compostos nitrogenados.

5. Essa reação cria subprodutos tóxicos.

\section{carcuming}

1. É um pigmento natural.

2. Se encontra na forma de pó e sua cor é amarela alaranjada.

3. É um alimento nutracêutico.

4. Pode ser utilizado na prevenção ou tratamento de doenças como as cardiovasculares e o câncer.

5. É um componente do açafrão-da-índia.

\section{Clorofilla}

1. Pode ser encontrado nas plantas.

2. Apresenta ação antioxidante.

3. Responsável pela realização da fotossíntese.

4. É utilizado industrialmente como corante natural.

5. É um pigmento de cor verde.

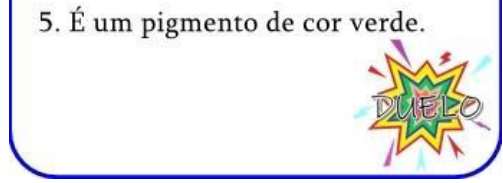




\section{REFERÊNCIAS}

[1] ARAÚJO, J. M. A. Química dos Alimentos- Teoria e Prática. 4ª ed. Viçosa, MG: Ed. UFV, 2008. 596p.

[2] CARDOSO, S. L. FOTOFÍSICA DE CAROTENÓIDES E O PAPEL ANTIOXIDANTE DE $\beta$-CAROTENO. Química Nova, [s. l], v. 20, n. 5, p. 535-540, 1997.

[3] COUlTATE, T. P. Alimentos: A quimica de seus componentes. $3^{3}$ ed. Porto Alegre: Artmed, 2004.368p.

[4] CRIZEL, R. L. Prospecção de pigmentos produzidos por cochonilhas Ceroplastesspp. para aplicação em alimentos. 2017. 62 f. Dissertação (Mestrado) Curso de Ciência e Tecnologia de Alimentos, Universidade Federal de Pelotas, Pelotas, 2017.

[5] DAMODARAN, S.; PARKIN, K. L.; FENNEMA, O. R. Quimica de Alimentos de Fennema. 4a ed.Porto Alegre: Artmed, 2010. 900p.

[6] FABRI, E. G.; TERAMOTO, J. R. S. Urucum: fonte de corantes naturais. Horticultura Brasileira, [S.L.], v. 33, n. 1, p. 140-140, mar. 2015. FapUNIFESP (SciELO). http://dx.doi.org/10.1590/s0102-053620150000100023.

[7] FERREIRA, W. M.; ROCHA, L. B.; SANTOS, L. D.; SANTOS, B. L.; PITANGA, A. F. Corantes: Uma abordagem com enfoque ciência, tecnologia e sociedade (CTS) usando processos oxidativos avançados. Revista Química Nova na Escola, São Paulo, v. 40, n. 4, p. 249-257, 2018.

[8] HAMERSKI, L.; REZENDE, M. J. C.; DA SILVA, B. V. Usando as cores da natureza para atender aos desejos do consumidor: substâncias naturais como corantes na indústria alimentícia. Revista Virtual de Química, v. 5, n. 3, p. 394-420, 2013.

[9] INSTITUTO BRASILEIRO DE DEFESA DO CONSUMIDOR. Você sabe o que é Caramelo IV? Disponível em: https://idec.org.br/consultas/dicas-e-direitos/voce-sabeo-que-e-caramelo-iv. Acesso em: 05 out. 2012.

[10] LOPES, R. M.; OLIVEIRA, T. T. de; NAGEM, T. J.; PINTO, A. da S. Farmacologia de flavonóides no controle hiperlipidêmico em animais experimentais. Biotecnologia Ciência \& Desenvolvimento, [s. l], v.17, p. 18-22, 2000.

[11] MUCCIOLO, P.; BARBUTO, O.; CAMPOS, M. M. TEOR DE VITAMINA A E CAROTENO EM MANTEIGAS CONSUMIDAS EM SÃO PAULO. Rev. Fac. Med. Vet., São Paulo, v. 5, n. 3, p. 551-561, 1995.

[12] OLIVEIRA, V. P. de; ESPESCHIT, A. C. R.; PELUZIO, M. do C. G.; FLAVONÓIDES E DOENÇAS CARDIOVASCULARES: AÇÃO ANTIOXIDANTE. Rev Med Minas Gerais, [s. l], v. 16, n. 4, p. 234-238, 2006.

[13] PEIXOTO, F. P.; MARINHO, G.; RODRIGUES, K. Corantes têxteis: uma revisão. Holos, v. 5, p. 98-106, 2013. 
[14] PRADO, Marcelo Alexandre; GODOY, Helena Teixeira. Corantes artificiais em alimentos. Alimentos e Nutrição Araraquara, v. 14, n. 2, 2009.

[15] SILVA, A. P.; LIMA, C.L.C. de; VIEITES, R. L. CARACTERIZAÇÃO QUÍMICA E FÍSICA DO JENIPAPO (Genipa americana L.) ARMAZENADO. Scientia Agricola, [S.L.], v. 55, n. 1, p. 29-34, jan. 1998. FapUNIFESP (SciELO). http://dx.doi.org/10.1590/s010390161998000100006.

[16] STREIT, N. M.; CANTERLE, L. P.; CANTO, M. W. do; HECKTHEUER, L. H. H. As clorofilas. Ciência Rural, [S.L.], v. 35, n. 3, p. 748-755, jun. 2005. FapUNIFESP (SciELO). http://dx.doi.org/10.1590/s0103-84782005000300043.

[17] TEIXEIRA, L. V. ANÁLISE SENSORIAL NA INDÚSTRIA DE ALIMENTOS. Rev. Inst. Latic, [s. l], v. 366, n. 64, p. 12-21, 2009. 


\section{Jogo 5}

\section{É corante mesmo!}

\section{Francinildo da Silva Brito}

Maria da Conceição Tavares Cavalcanti Liberato 


\section{INTRODUÇÃO}

Esse jogo foi idealizado para fornecer ao aluno do Ensino Médio ações pedagógicas que os auxiliem na familiarização de conhecimento, possibilitando interação entre eles. Como estratégias de ensino, treinar habilidades já estudadas e aprofundar questões importantes. 0 objetivo do jogo envolve o jogador a ajudar os arqueólogos a encontrarem informações sobre os corantes naturais já que, ao longo da história, os corantes naturais foram usados pelo homem há milênios desde a época das cavernas quando os primeiros homens gravaram uma parte de sua história com carvão, argila de diversas cores e pedras. A arte rupestre é testemunha da procura do homem por retratar, de forma colorida, aspectos importantes de sua vida. Mas, para ajudá-los, é necessário responder corretamente as perguntas e respeitar as ações impostas aos jogadores no tabuleiro.

\section{MATERIAIS E MÉTODOS}

0 jogo consta de um tabuleiro, dado e perguntas a serem respondidas de acordo com o nível de dificuldade delas (fácil, médio e difícil). Cada jogador, na sua vez, joga o dado e anda as casas que ele indicar. Caso pare nas perguntas será necessário respondêlas corretamente para avançar o indicado pelo nível das questões, por exemplo, questões consideradas fáceis, respondidas corretamente, anda somente 1 casa a frente, caso contrário volta 1 casa. Já as perguntas consideradas média e difícil quando respondidas corretamente andam 2 e 3 casas, respectivamente; caso erre, volta a mesma quantidade de casas. 0 jogador deve respeitar as ações no tabuleiro para avançar, retornar algumas casas ou ficar sem jogar rodadas seguintes. Será estipulado um tempo de 1 hora para duração do jogo.

\section{Ações no Tabuleiro}

- 6. Deu carona: Avança 2 casas;

- 12.Atrapalhou nas investigações: Fica sem jogar 2 rodadas;

- 16. Ofereceu abrigo: Jogue outra vez;

- 24. Espalhou fake news: Voltar ao início do jogo;

- 29. Ficou doente: Ficar 1 rodada sem jogar, porém, ganha ajuda na próxima pergunta (dica);

- 33. Placa de advertência: Responder corretamente à pergunta e andar a quantidade de casas que o dado indicar. Nas respostas erradas não andará as casas indicadas no dado.

- 38. Encontrou informações importantes: Avançar 3 casas;

- 40. Salvou amigo: Avançar 4 casas.

- 43. Quer desistir da missão: 0 jogador que parar nessa ação responderá 2 perguntas seguidas para prosseguir no jogo, caso contrário ficará uma rodada sem jogar. 
Figura 1: Tabuleiro e Cartas

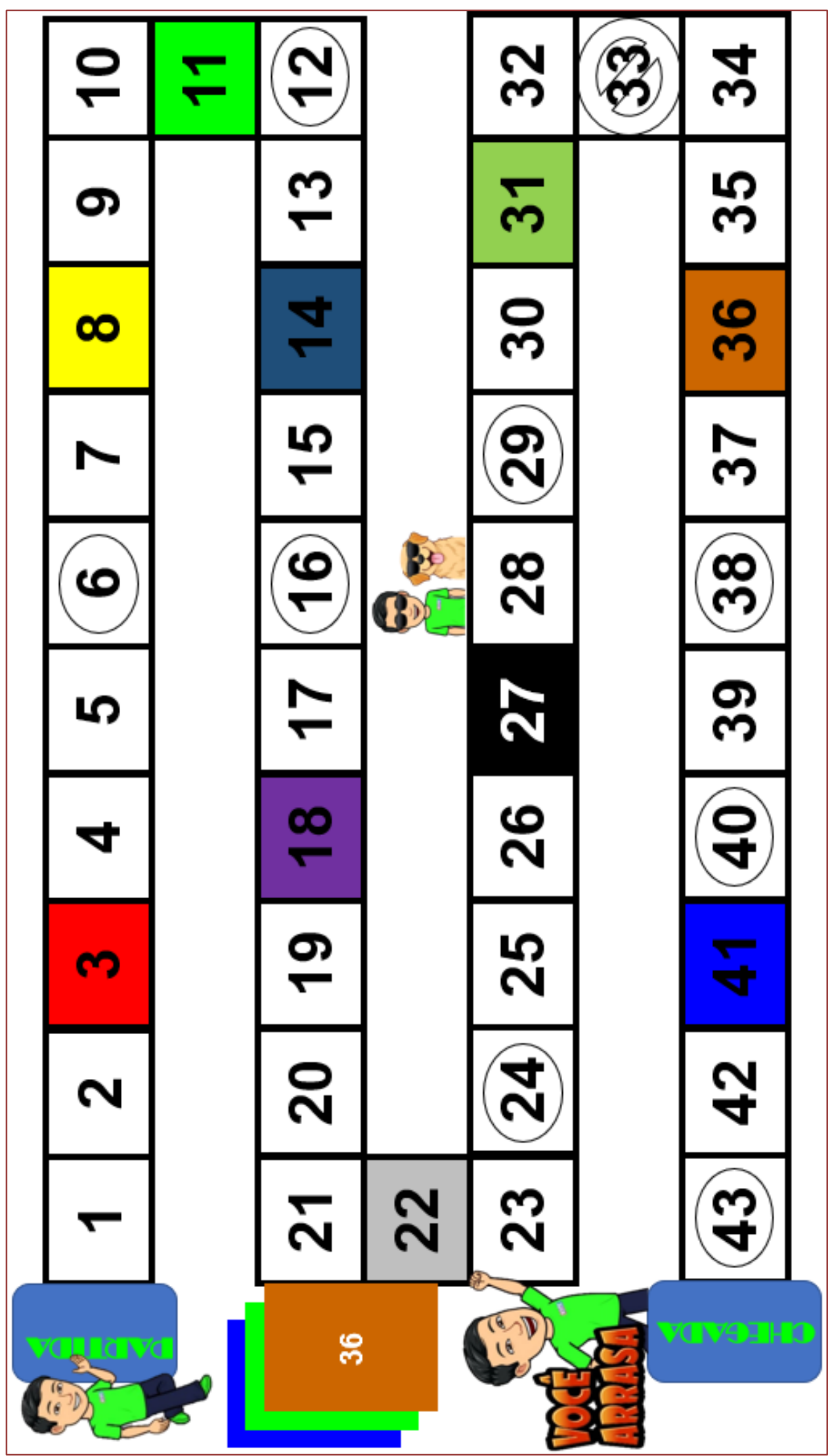




\section{RESULTADOS}

0 jogo foi experimentado em grupos de alunos do Curso de Licenciatura em Química da Universidade Estadual do Ceará que fazem parte do “Grupo de Estudos sobre Pigmentos e Corantes", obtendo aprovação unânime.

\section{CONCLUSÃO}

O jogo educativo sobre pigmentos cumpre bem o seu propósito, pois desafia os jogadores a solucionarem problemas, resultando em uma autorreflexão acerca do seu rendimento e uma boa interação entre eles. Com isso, o processo de ensinoaprendizagem torna-se mais prazeroso se feito de maneira correta e sob orientação de um professor.

\section{Perguntas nas Cartas do Tabuleiro}

- 3. A pigmentação influencia positivamente na escolha de um alimento? Nível fácil

- 8. Aponte as diferenças entre corantes naturais e artificiais, destacando as vantagens de cada um deles? Nível médio

- Qual é o pigmento mais encontrado nas frutas e hortaliças? Nível fácil

- 0 pH influencia na degradação de alguns pigmentos; caso afirmativo, quais são eles e como são afetados? Nível difícil

- 18. Os carotenoides podem ser desestabilizados por quais motivos? Nível médio

- 22. Por que os carotenoides são considerados substâncias antioxidantes? Nível médio

- 27. Indique as vantagens e as desvantagens do pigmento produzido pela cochonilha. Nível fácil

- 31. Quais corantes naturais você usaria para as gelatinas sabores morango, uva, laranja, limão e pêssego? Nível difícil

- 36. A palavra natural nos rótulos é importante economicamente, e sua utilização na rotulagem transmite a sensação de produto saudável. Entretanto, a sua inocuidade deve ser confirmada, visto que nem tudo que é natural é sinônimo de saudável. Tal afirmação procede? Nível fácil

- 41. 0 que pode ser feito para aumentar a estabilidade de corantes naturais? Nível médio 


\section{Respostas das perguntas}

- 3. A pigmentação do alimento influencia na sua escolha porque isso faz parte da percepção sensorial, em torno de 87\% das informações é capturado pelos olhos.

- 8. Os Corantes naturais são substâncias produzidas por vegetais ou animais, já o caramelo resulta-se da fusão de açúcares. Diferentemente, os corantes artificiais são encontrados em materiais minerais que sofrem processo de purificação em alimentos. Em relação as vantagens, os corantes artificiais apresentam estabilidade a luz, ao oxigênio, ao calor e ao $\mathrm{pH}$, pois além de deixar um aspecto uniforme na cor, apresenta um alto poder tintorial. Sem contar que eles combatem os microrganismos e apresenta custo de produção relativamente baixo. Já os corantes naturais, por se tratar de um produto natural, apresenta uma maior aceitação no mercado, aos poucos vem substituindo os corantes artificiais, alguns são solúveis em óleos.

- 11. A clorofila é o pigmento mais encontrados nos vegetais, apresenta coloração verde e tem importância estrutural.

- 14. Sim, dependendo do meio que se encontram esses pigmentos, suas estruturas mudam sua forma de acordo com o meio. A clorofila, por exemplo, apresenta mais estável ao calor em meio básico. Já as betalaínas e as antocianinas, por serem bastantes instáveis, podem apresentar mais colorações de acordo com seus pH específicos.

- 18. Os carotenoides são bastante sensíveis ao calor, a luz e ao oxigênio, facilitando na sua decomposição. Esses fatores podem influência negativamente em sua composição.

- 22. Porque eles apresentam, em sua composição, a presença de muitas duplas ligações, o que faz deles capazes de sequestrar espécies reativas de oxigênio, estabilizando o elétron desemparelhado do radical por ressonância.

- 27. Vantagem: natural e não possui toxicidade. Desvantagem: possui grande impacto biológico.

- 31. Morango: Antocianina; Uva: Carotenoides; Laranja: Carotenoides; Limão: Clorofila; Pêssego: Cúrcuma.

- 36. Sim.

- 41. Deve-se controlar o pH, a exposição à luz, exposição ao oxigênio, temperatura, atividade de água, dentre outras particularidades de cada corante que favorecem a degradação dos mesmos. 


\section{REFERÊNCIAS}

[1] CRUZ, A. J. Os pigmentos naturais utilizados em pintura. Pigmentos e Corantes Naturais. Entre as artes e as ciências. Évora: Universidade de Évora, p. 5-23, 2007.

[2] CONSTANT, P. B. L.; STRINGHETA, P. C.; SANDI, D. Corantes alimentícios. Boletim do Centro de Pesquisa de Processamento de Alimentos, v. 20, n. 2, 2002.

[3] CONSTANT, P. B. L.; STRINGHETA, P. C.; SANDI, D. Corantes alimentícios. Boletim do Centro de Pesquisa de Processamento de Alimentos, v. 20, n. 2, 2002.

[4] DE OLIVEIRA, A. L. et al. O jogo educativo como recurso interdisciplinar no ensino de química. 2018.

[5] MORAIS, F. L. D. Carotenoides: características biológicas e químicas. 2006.

[6] SCHIOZER, A. L. et al. Estabilidade de corantes e pigmentos de origem vegetal. 2013. 


\section{Jogo 6}

\section{Quimiquest: Estrada da cor}

Cecília Guimarães Lemos

Maria da Conceição Tavares Cavalcanti Liberato 


\section{INTRODUÇÃO}

A vasta utilização de corantes e pigmentos em alimentos e objetos é decorrente da necessidade de uma melhoria na aparência do produto, pois a cor bem viva e definida é um grande fator na decisão de compra, logo os produtos industrializados tem uma melhora em suas vendas pois apresentam um visual atrativo que não se estraga com facilidade (SAMPAIO, 2019).

Corantes e Pigmentos se desenvolvem do mesmo conceito, substâncias que conferem cor a um material, porém concentram algumas diferenças entre si, principalmente em relação a resistência, opacidade, poder tintorial, classificações e uso (IV CONSELHO REGIONAL DE QUÍMICA, 2011).

Apesar de conter pouco corante ou pigmento na maioria dos produtos, o aumento do consumo de materiais que utilizam uma substância colorante faz com que cresça a preocupação sobre o potencial toxico, alergênico e carcinogênico em curto e longo prazo (LINDINO et al., 2008).

É evidente a necessidade de ensinar a crianças e adolescentes sobre pigmentos e corantes, seus benefícios e malefícios, visando instruir consumo de materiais, objetos e alimentos mais responsáveis e saudáveis.

Um importante meio educacional que propicia um desenvolvimento psicomotor e auxilia na fixação do conteúdo é o jogo didático, sendo ele uma aprendizagem dinâmica onde o aluno põe a prova o seu conhecimento se divertindo, logo faz uma boa associação aquele conteúdo, aumentando as chances de aprendizagem efetiva e ainda contribui para a cooperação com outros alunos, aumentando o entrosamento e a socialização (BOLLER; KAPP, 2018).

\section{MATERIAL E MÉTODOS}

\section{Confecção do Jogo}

QuimiQuest: Estrada da cor, é um jogo no modelo de trilha que utiliza de um sistema de perguntas e respostas para percorrer o tabuleiro e vencer.

\section{O jogo conta com:}

- 1 tabuleiro com 15 casas, sendo 5 casas intituladas "Cor da Sorte", 1 sendo o início e 1 sendo o fim.

- 20 Cartas do tipo pergunta, 6 sendo "corante ou pigmento?" 9 sendo "verdadeiro ou falso" e 10 sendo "múltipla escolha", as perguntas foram desenvolvidas pensando no nível escolar dos alunos, sendo eles de ensino fundamental e médio.

- 20 Cartas do tipo “Cor da Sorte”, sendo 10 de sorte, propiciando ao jogador avançar casas por pegar um corante ou pigmento benéfico a saúde e sendo 10 de azar, propiciando ao jogador voltar casas por pegar um corante ou pigmento maléfico a saúde.

- 6 peões sendo 1 vermelho, 1 azul, 1 verde, 1 amarelo, 1 preto e 1 branco.

- 1 dado de seis faces. 
- 0 tabuleiro pode ser impresso em papel adesivo para ser colado em uma superfície mais dura como compensado de madeira ou papelão ou pode ser impresso em folha comum e colado em uma superfície mais dura.

- As cartas podem ser impressas em papel de gramatura elevada, frente e verso ou pode ser impressa em papel comum de baixa gramatura, frente e verso.

- Os peões podem ser impressos em papel ou adaptados para compra.

- O dado pode ser impresso ou comprado.

\section{Objetivo do jogo}

- Definir corantes e pigmentos.

- Identificar as principais diferenças entre corantes e pigmentos e seus malefícios e benefícios.

- Localizar onde os corantes e pigmentos são utilizados.

Regras e modo do jogo.

O jogo QuimiQuest: Estrada da cor pode ser executado em quatro passos:

1. 0 professor deve dividir a sala em até 6 grupos de $X$ integrantes, os grupos irão jogar o dado e estabelecer a ordem de jogada dos grupos.

2. O grupo que vai começar deve puxar uma carta pergunta e responder, sendo respondida corretamente irá jogar o dado para saber quantas casa irá avançar, se for respondida errada não irá avançar e deve esperar a próxima rodada.

3. Ao cair em uma casa com o símbolo de uma estrela, deve puxar uma carta "Cor da Sorte" e saber se recebe uma carta "Azar" de acordo com o seu corante (ex: Amarelo Tartrasina é um corante artificial associado à caso de asma, volte 2 casas) ou uma carta "Sorte" (ex: Pigmento natural Licopeno ajuda à regular os batimentos cardíacos, avance 3 casa).

4. O grupo que conseguir chegar até o final vence. 
Tabuleiro do jogo

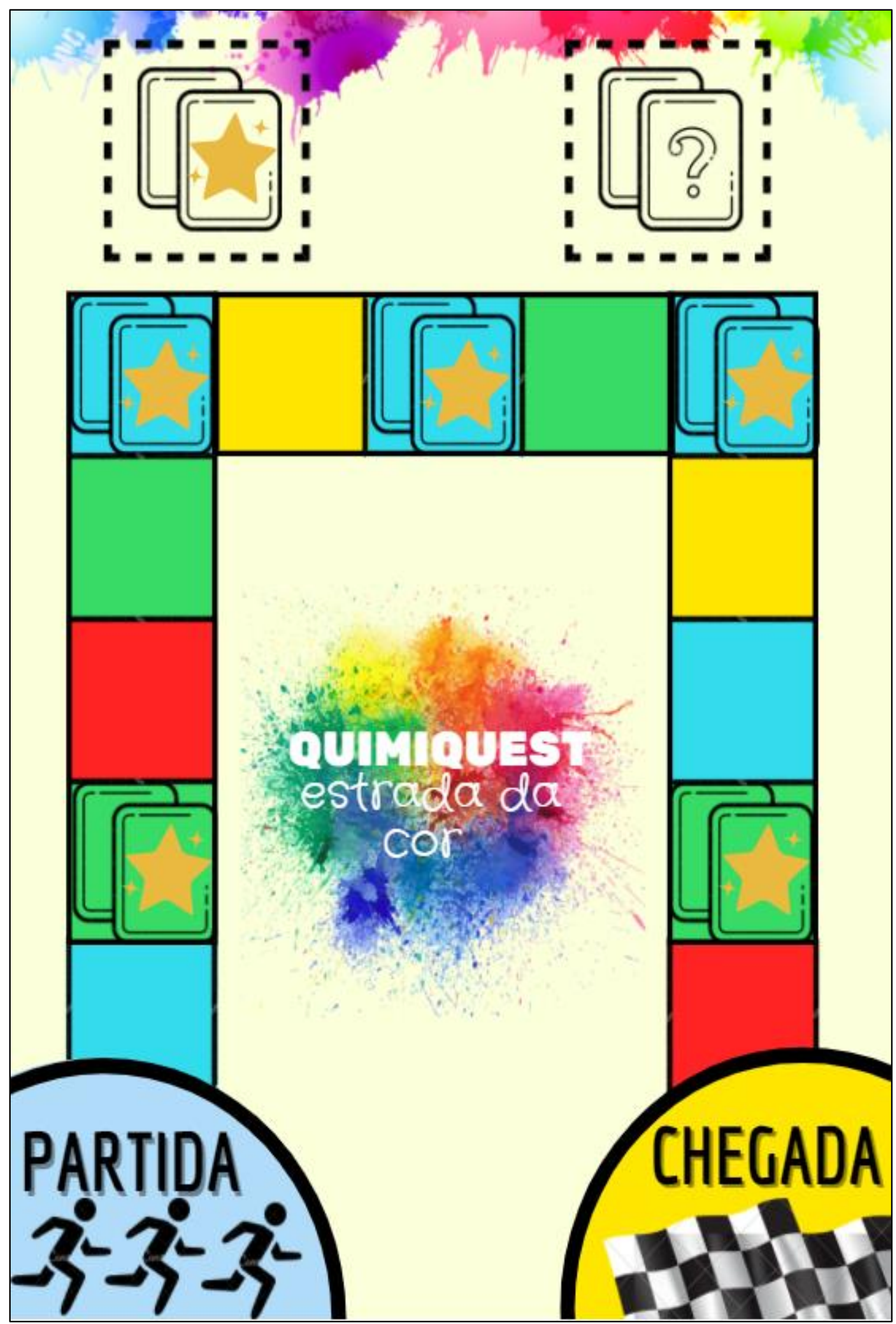




\section{Cartas perguntas}

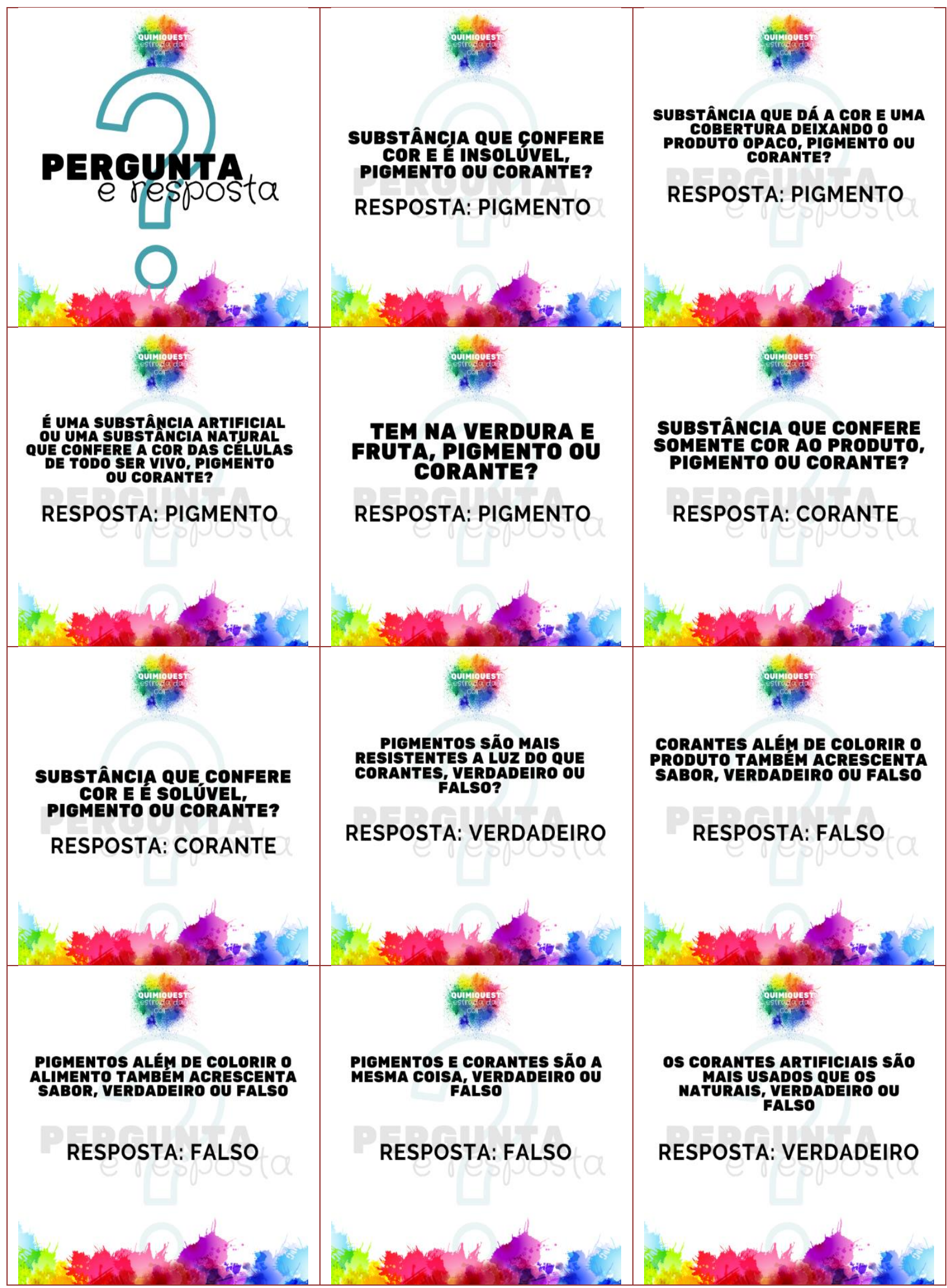




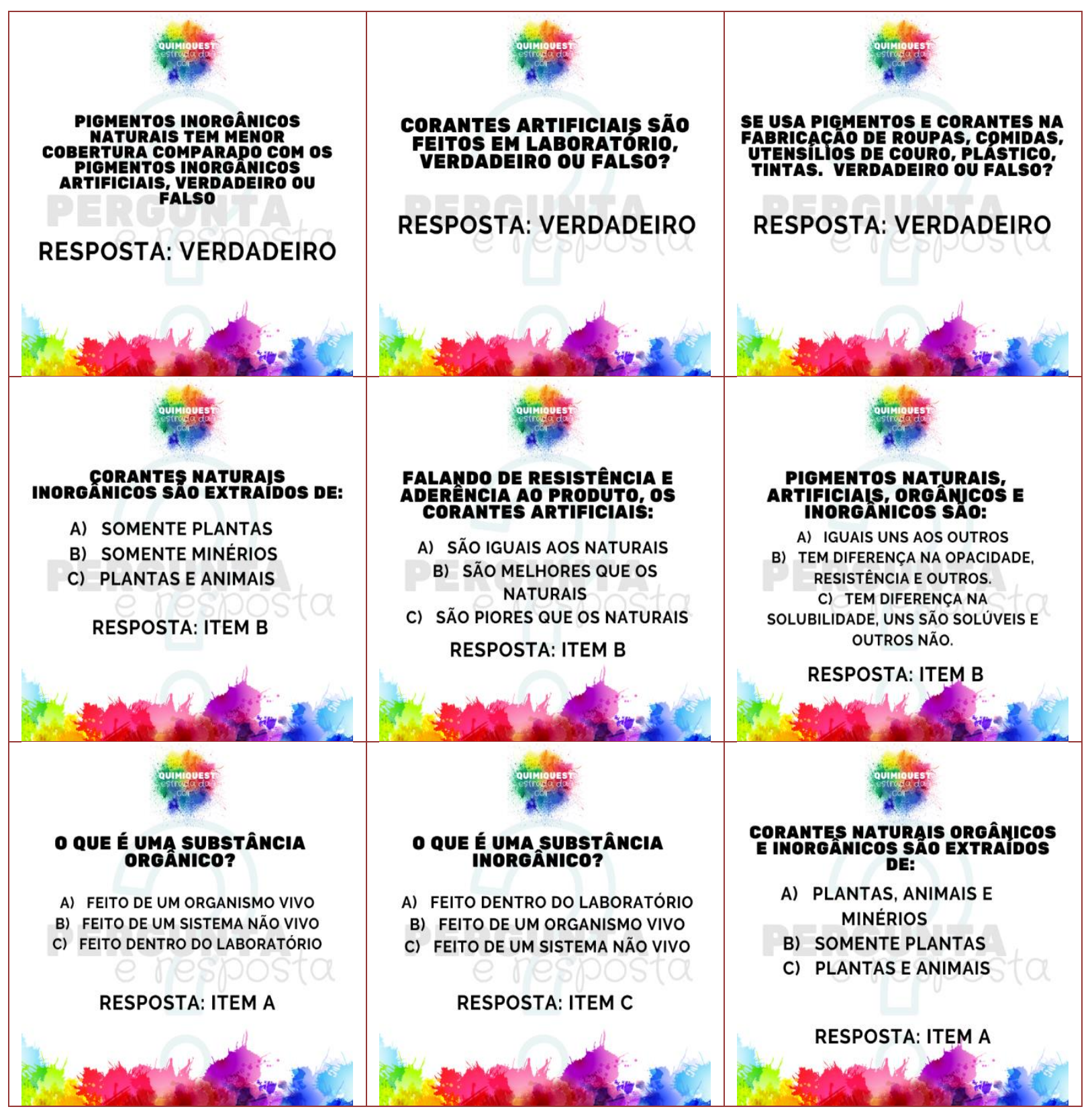


Cartas de apoio (Cor da sorte)

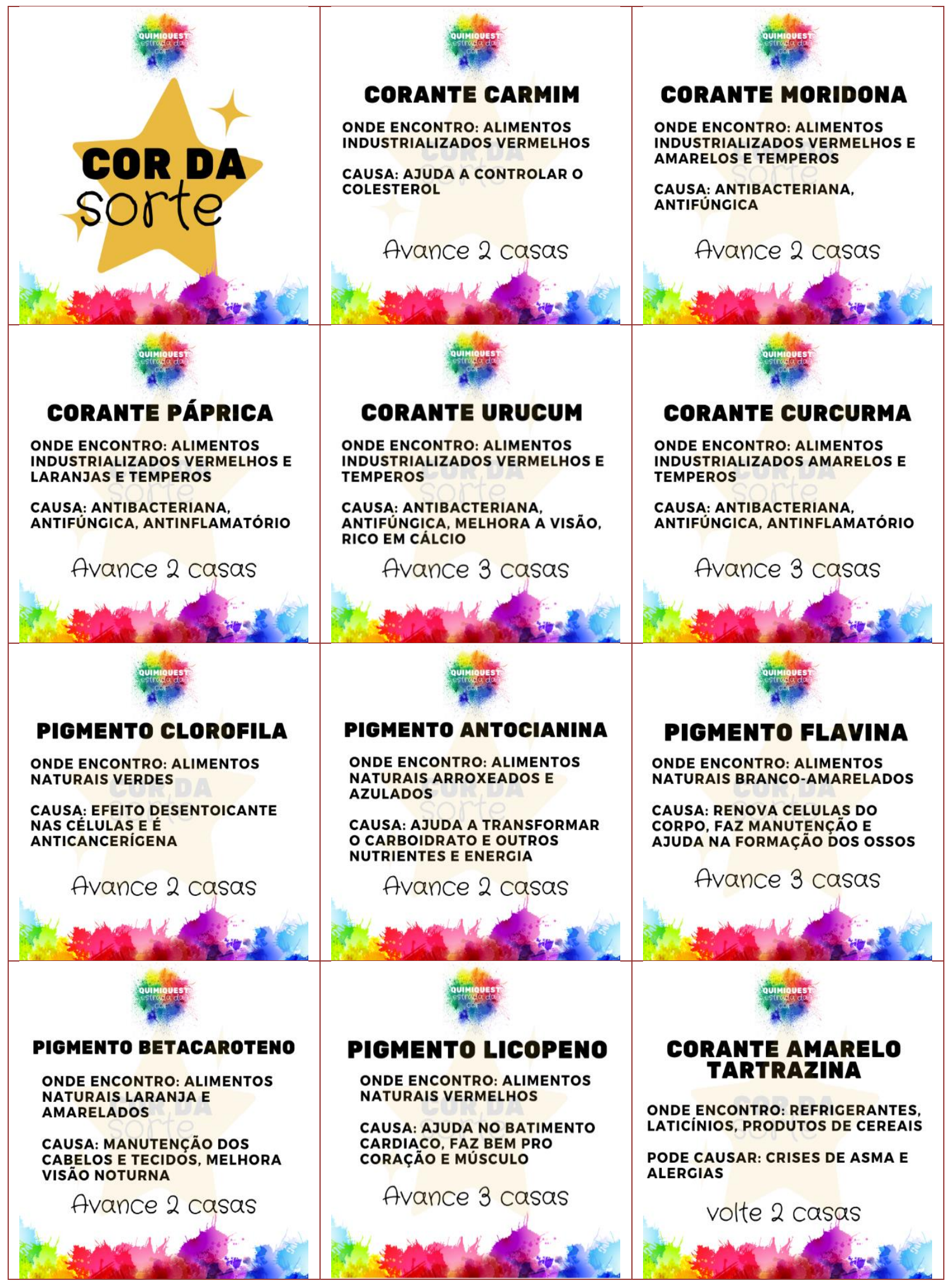




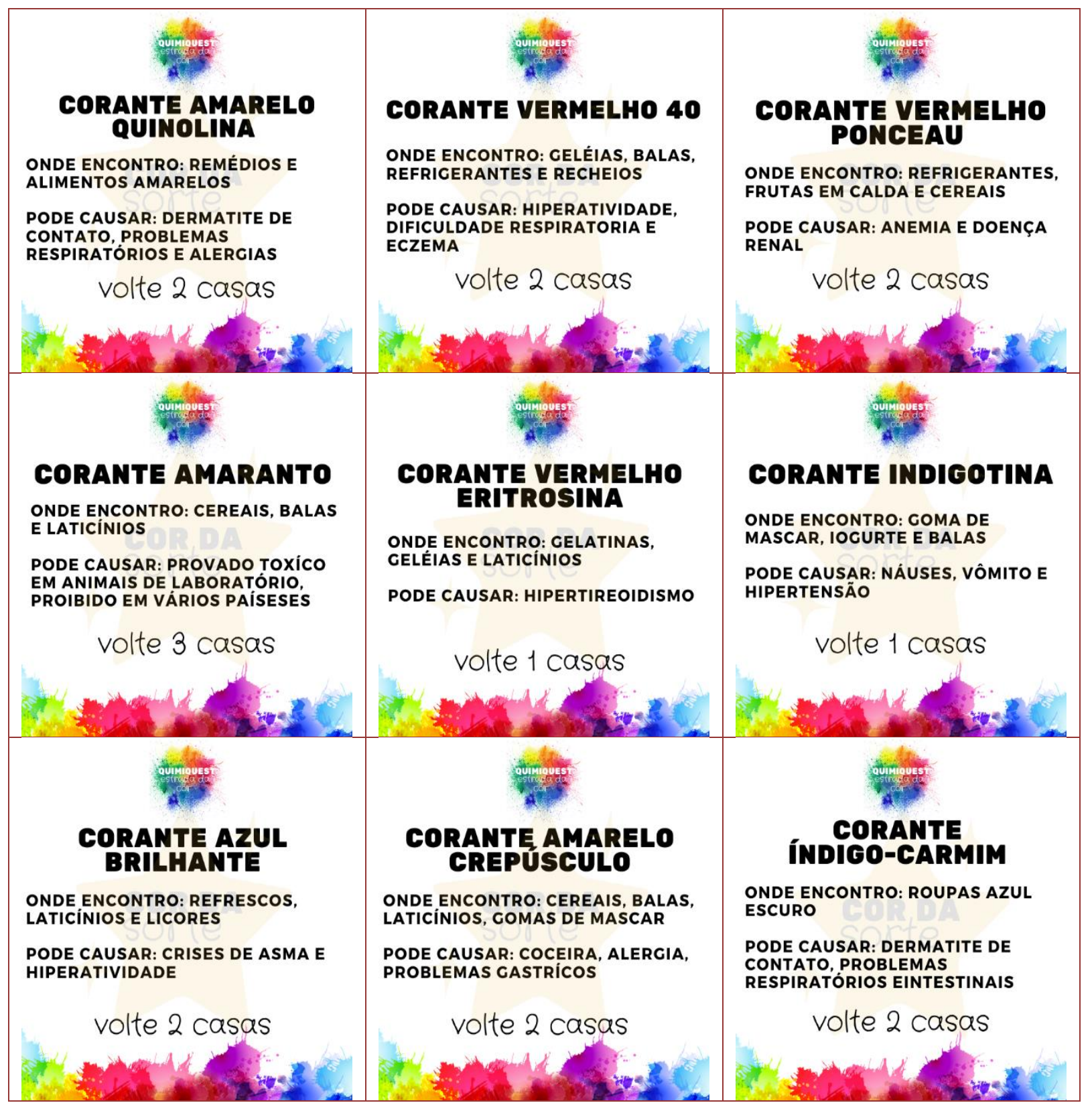




\section{CONCLUSÃO}

Em virtude da rápida jogabilidade do jogo, visual chamativo e interativo, se espera que QuimiQuest: Estrada da Cor proporcione aos alunos de ensino médio consigam exercitar e fixar o conteúdo sobre pigmentos e corantes ministrado em sala de aula.

Sendo evidente a importância deste assunto, visto que está diretamente ligado a diversas alterações no organismo, algumas delas maléficas, como alergias, problemas gastrointestinais e respiratórios e outras benéficas, como a ajuda na manutenção do funcionamento do corpo, abrangendo órgãos e tecidos, desde o coração aos ossos.

0 jogo foi desenvolvido pensando em ser rápido, para que o professor possa aplica-lo em uma aula ou menos, colorido, para ativar a lembrança aos corantes e pigmentos na mente do aluno, interativo, por meio de perguntas e respostas e cartas coringa e incentivar o trabalho em equipe, já que os grupos terão de trabalhar juntos para vencerem.

\section{REFERÊNCIAS}

[1] BOLER, S; KAPP, Karl. Jogar para aprender: Tudo o que você precisa saber sobre o design de jogos de aprendizagem eficazes. São Paulo, SP: DVS Editora, 2018.

[2] FEITOSA, Luana Carolina Alves. Estimativa de ingestão do corante amarelo crepúsculo e quantificação em alimentos consumidos pela população brasileira. 2016. Dissertação (Mestrado em Ciência e Tecnologia de Alimentos) - Programa de PósGraduação em Ciência e Tecnologia de Alimentos, Universidade Federal do Rio Grande do sul, Porto Alegre, 2016.

[3] IV CONSELHO REGIONAL DE QUÍMICA. Corantes e Pigmentos. São Paulo, SP. 22 jun. 2011. Blog: https://www.crq4.org.br/print_ver.php?p=28248. Acesso em: 02 nov. 2020

[4] LINDINO, Cleber Antonio; GONÇALVES JR, Affonso Celso; SCHREINER,Gracilene Gisele Orth; SCHREINER, Jackson Spohr; De FARINA, Luciana Oliveira. Determinação de metais em corantes alimentícios artificiais. Acta Scientiarum. Technology, Maringá, PR, v. 30, n. 1, p. 93-98. fev./mar. 2008.

[5] MORETS, Débora Nogueira; GERON, Vera Lúcia Matias Gomes. Os benefícios medicinais da Curcuma longa L. (Açafrão da Terra). Revista Científica da Faculdade de Educação e Meio Ambiente, Ariquemes, R0, v. 10, n. 1, p. 106-114, jan./jun. 2019.

[6] ROCHA, Danielly Santos; REED, Elaine. Pigmentos naturais em alimentos e sua importância para a saúde. Estudos, Goiânia, G0, v. 41, n. 1, p. 76-85, jan./mar. 2014.

[7] RODRIGUEZ-AMAYA, DÉLIA B. Natural food pigments and colorants. Current opnion in food Science, Holanda, v. 7, p. 20-26, 2016. Disponível em: https://www.sciencedirect.com/science/article/abs/pii/S2214799315001046?via\%3D ihub.

[8] SAMPAIO, Asaf Hanâni Taveira. Corantes Artificiais x Corantes Naturais: Uma visão gastronômica. 2019. Trabalho de Conclusão de Curso (Graduação em Gastronomia) - Instituto de Culta e Arte, Universidade Federal do Ceará, Fortaleza, 2019. 
[9] SILVA, Nayara Cristina Oliveira; REED, Elaine. Estudo sobre corantes artificiais em alimentos: Quais os riscos mais comuns pelo consumo excessivo. Educação, Tecnologia e Sociedade. Trabalho apresentado no II SIMPOETS, 2011, Inhumas, GO.

[10] SILVA, Patricia Muniz dos Santos; ROSSI, Ticiane; MENDES, Francisca Dantas; ARAÚJO, Aretha de Oliveira. Moda Íntima: Malefícios dos corantes sintéticos e benefícios dos corantes naturais. Anais 11 Colóquio de Moda. Curitiba, p. 2-14, set. 2015. Trabalho apresentado no $2^{\circ}$ Congresso Brasileiro de Iniciação Científica em Design e Moda, 2015, Curitiba, PR.

[11] VALENTE, Marina Coelho Hofmeister. Corante Artificiais: Estudo da estimativa de ingestão por criança e da percepção de adultos residentes no Rio Grande do Sul. 2018. Dissertação (Mestrado em Ciência e Tecnologia de Alimentos) - Programa de PósGraduação em Ciência e Tecnologia de Alimentos, Universidade Federal do Rio Grande do sul, Porto Alegre, 2008. 


\section{Jogo 7}

\section{Corrida das cores}

Layonara Dhuly da Silva Teixeira

João Vitor Araújo Souza

Maria da Conceição Tavares Cavalcanti Liberato 


\section{INTRODUÇÃO}

As cores estão presentes em diversos aspectos da vida humana, elas estimulam a visão, um dos principais sentidos de aceitação estética. Desde os primórdios da vida as cores indicam qualidade do alimento devido a presença de pigmentos que o colorem, como a clorofila nas plantas. Por conta da importância dessa característica a humanidade desenvolveu ao decorrer da história aplicação de produtos naturais ou sintéticos que colorem alimentos para atrair a aceitação. Esses materiais aplicados chamados de corantes ou pigmentos possuem características químicas especiais, podendo ser benéficos ou maléficos a saúde. (ROCHA; REED, 2014; PRADO; GODOY, 2003).

A partir do desenvolvimento científico e histórico desses materiais e sua importância ao cotidiano, foi elaborado um jogo de tabuleiro competitivo que aplica curiosidades sobre a química e história dos corantes e pigmentos em cartas de perguntas. Essa aplicação favorece a aplicação do conteúdo de forma divertida e espontânea.

\section{CORRIDA DAS CORES}

O jogo corrida das cores é um jogo de tabuleiro competitivo que estimula a aprendizagem de maneira extrovertida e dinâmica, os competidores competem com conhecimento e estratégia até que o primeiro atinja a chegada. 0 jogo é composto por 01 Tabuleiro, 04 peões, 01 dado, 40 cartas comuns e 09 cartas desafio. É indicado de 02 a 04 pessoas e tem uma duração média.

\section{INSTRUÇÕES}

Antes do início do jogo deve ser estabelecida a ordem de jogada dos participantes, para isso cada um lançará o dado uma vez e o maior será o primeiro a jogar da rodada e segundo maior será o segundo jogador e assim consecutivamente, para caso de empates os jogadores empatados deverão disputar entre si, o maior valor será o que jogará primeiro.

Em cada jogada, o competidor deve lançar o dado e o jogador a sua direita deve puxar uma carta comum e ler a pergunta, se ela for respondida corretamente o competidor que lançou o dado anda a quantidade completa que foi tirada na jogada, se a resposta for errada ele deve se mover a metade do valor, em casos de valores ímpares, a metade deve ser arredondada para o menor valor.

Cada casa do tabuleiro tem cores que se repetem em outras, os jogadores não podem ficar em casas de mesma cor, mesmo não sendo próximas, caso dois jogadores fiquem em uma casa com a cor igual eles devem fazer uma disputa, um jogador fora da disputa deve puxar uma carta de desafio e ler a pergunta o jogador da disputa que responder primeiro ganha a disputa se move uma casa e o que perder a disputa volta uma casa. Caso alguma casa da disputa possua estrela, a disputa não acontece e os jogadores permanecem inertes até sua vez de lançar o dado. A disputa só acontece a primeira vez que o jogador andar a casa na jogada.

As cartas comuns podem conter perguntas, curiosidades e ordens. Cartas com perguntas devem ser respondidas se estiverem corretas o jogador anda a quantidade de casas jogadas e casa a resposta esteja incorreta o jogador andará apenas metade. Cartas 
com curiosidades devem ser apenas lidas e o jogador anda a quantidade de casas mostradas no dado. As cartas de ordem possuem benefícios de acréscimos de $+1,+2$ e +3 casas na jogada, desvantagens de $-1,-2,-3$; passe uma rodada sem jogar ou desafiar um competidor. 
CARTAS

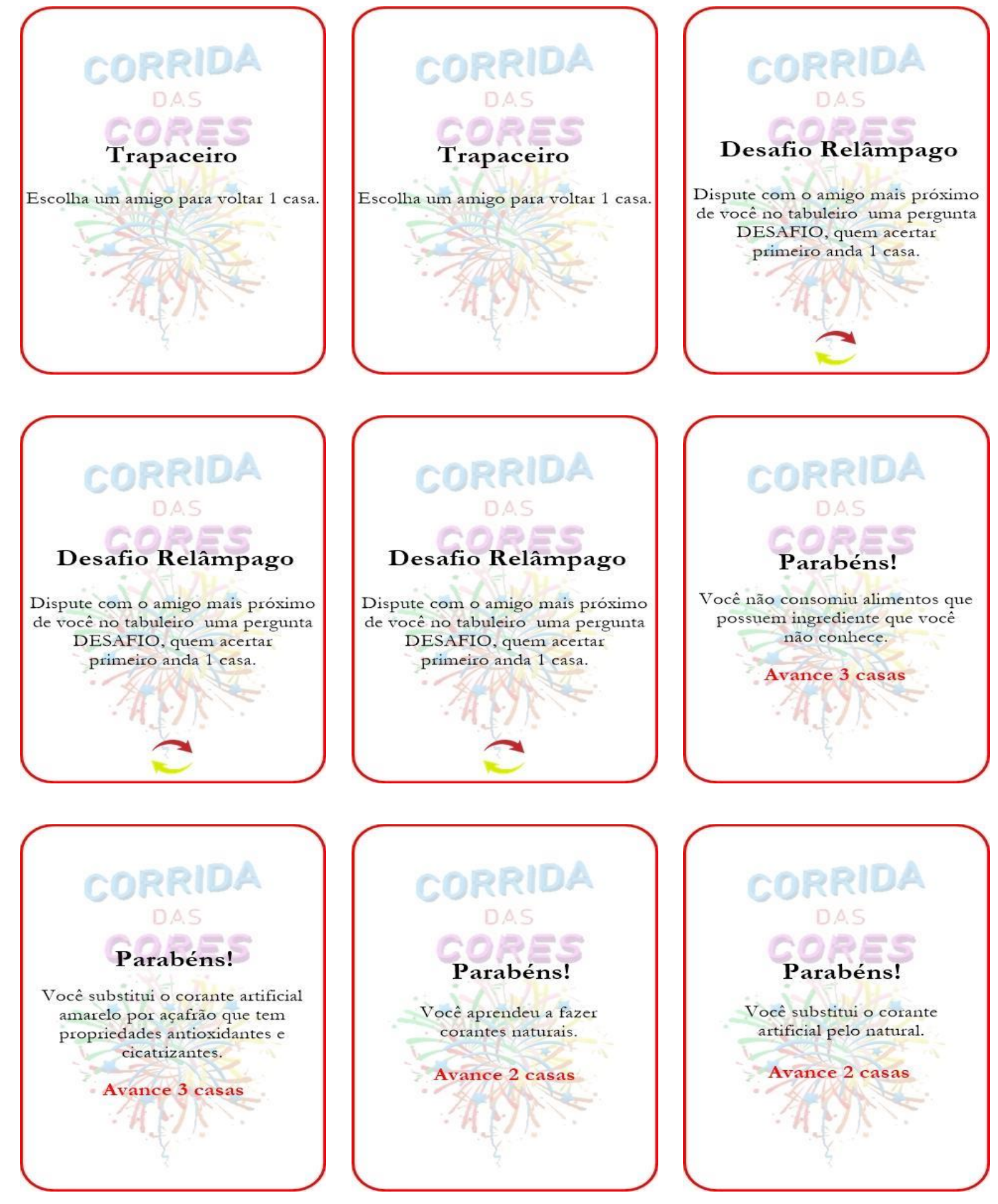



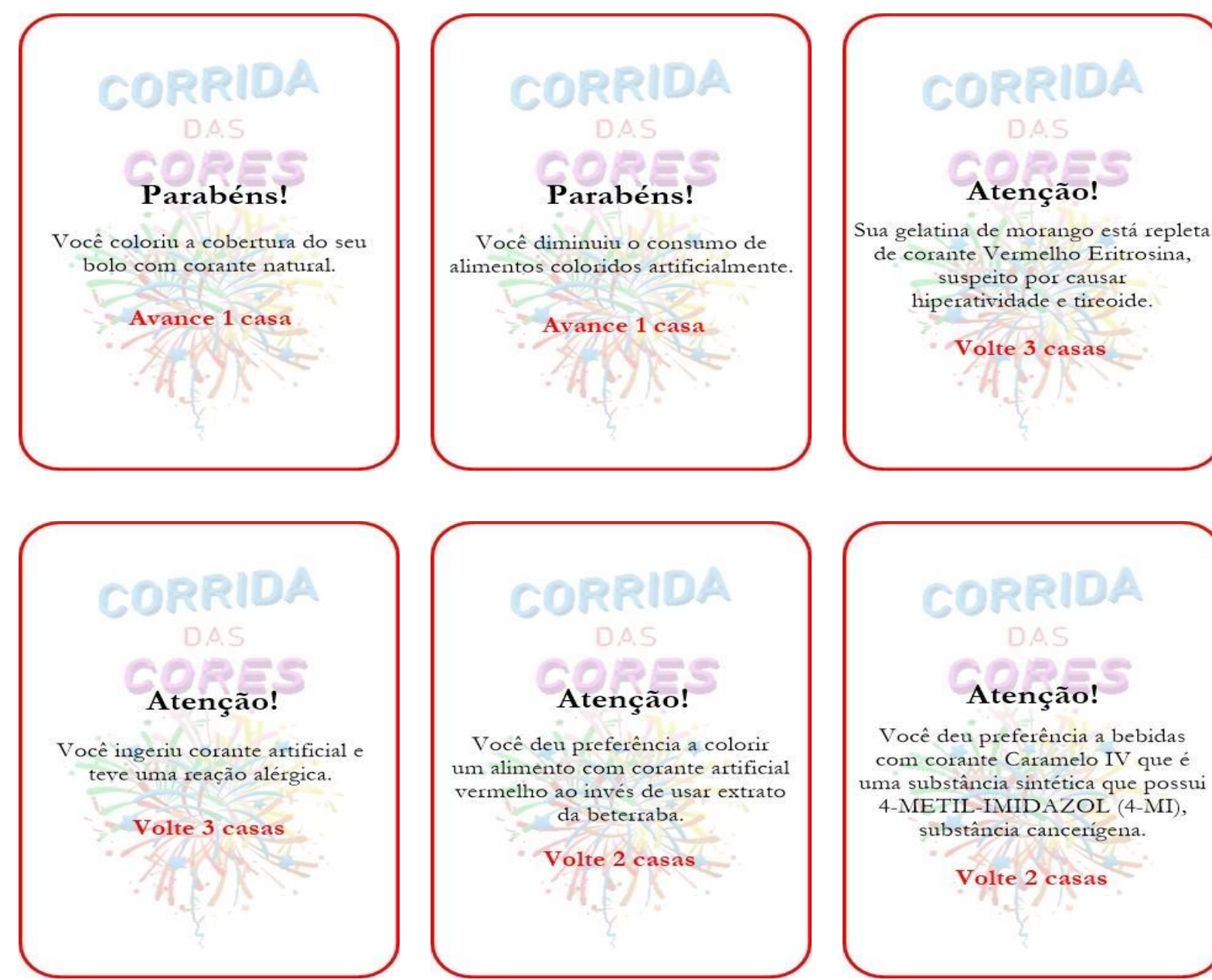

Sua gelatina de morango está repleta de corante Vermelho Eritrosina, suspeito por causar hiperatividade e tireoide. Volte 3 casas
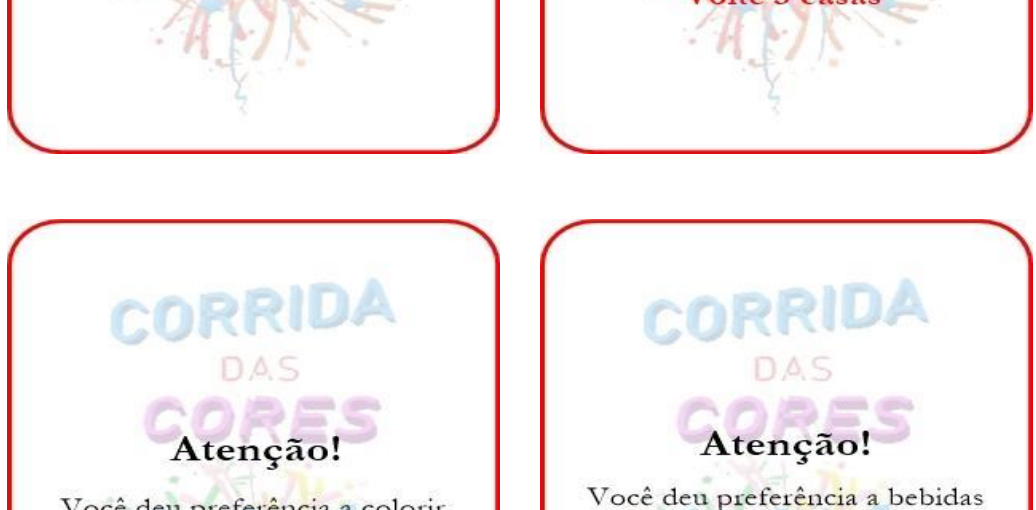

Você deu preferência a colorir um alimento com corante artificial vermelho ao invés de usar extrato da beterraba.

- Volte 2 casas

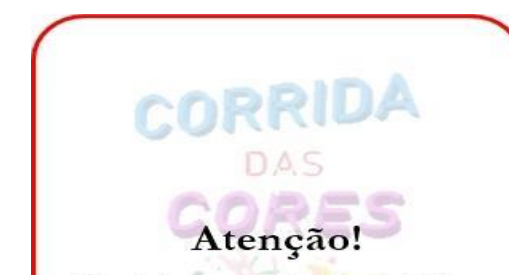

Você deu preferência a bebidas com corante Caramelo IV que é uma substância sintética que possui 4-METIL-IMID AZOL (4-MI), substância cancerigena.

Volte 2 casas Hos
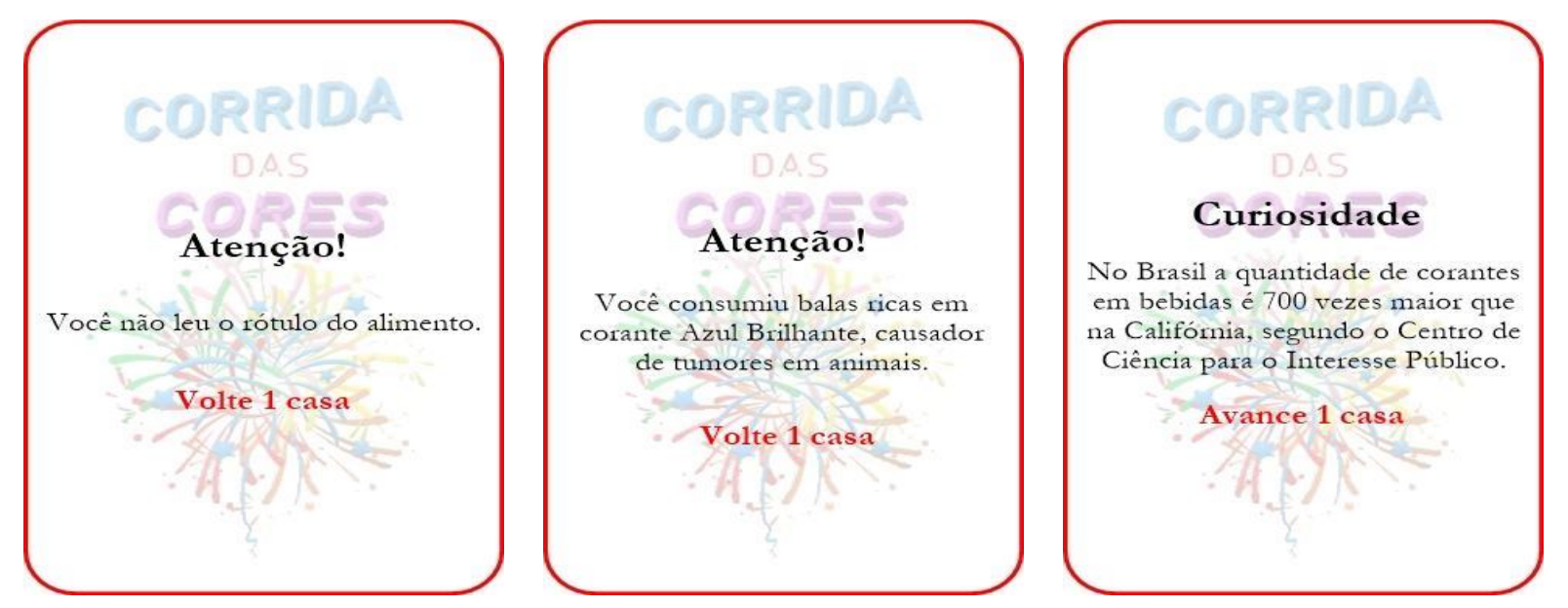

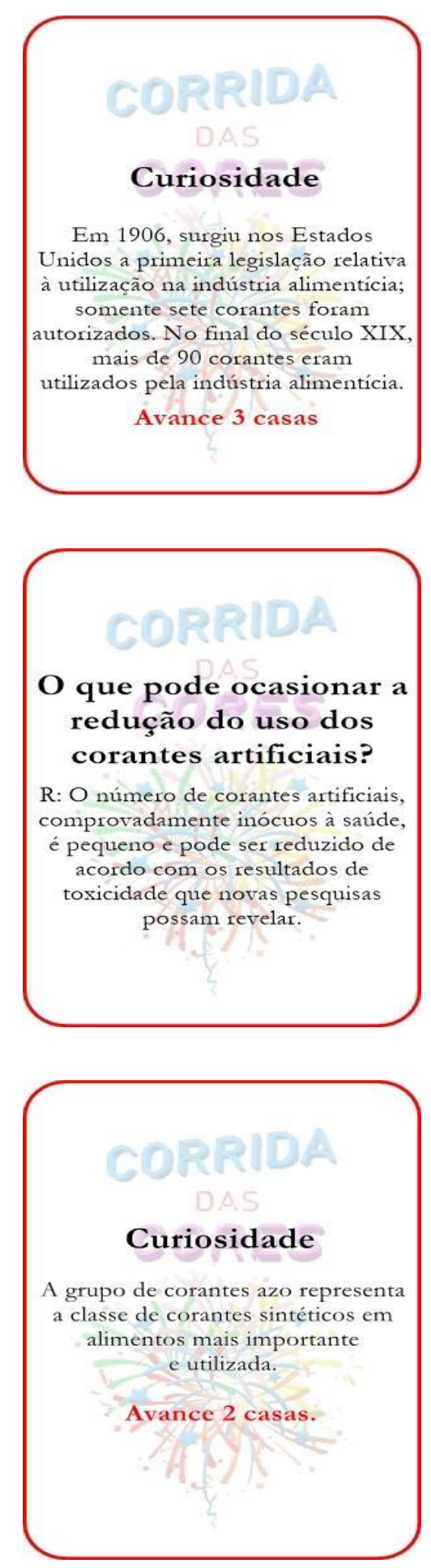
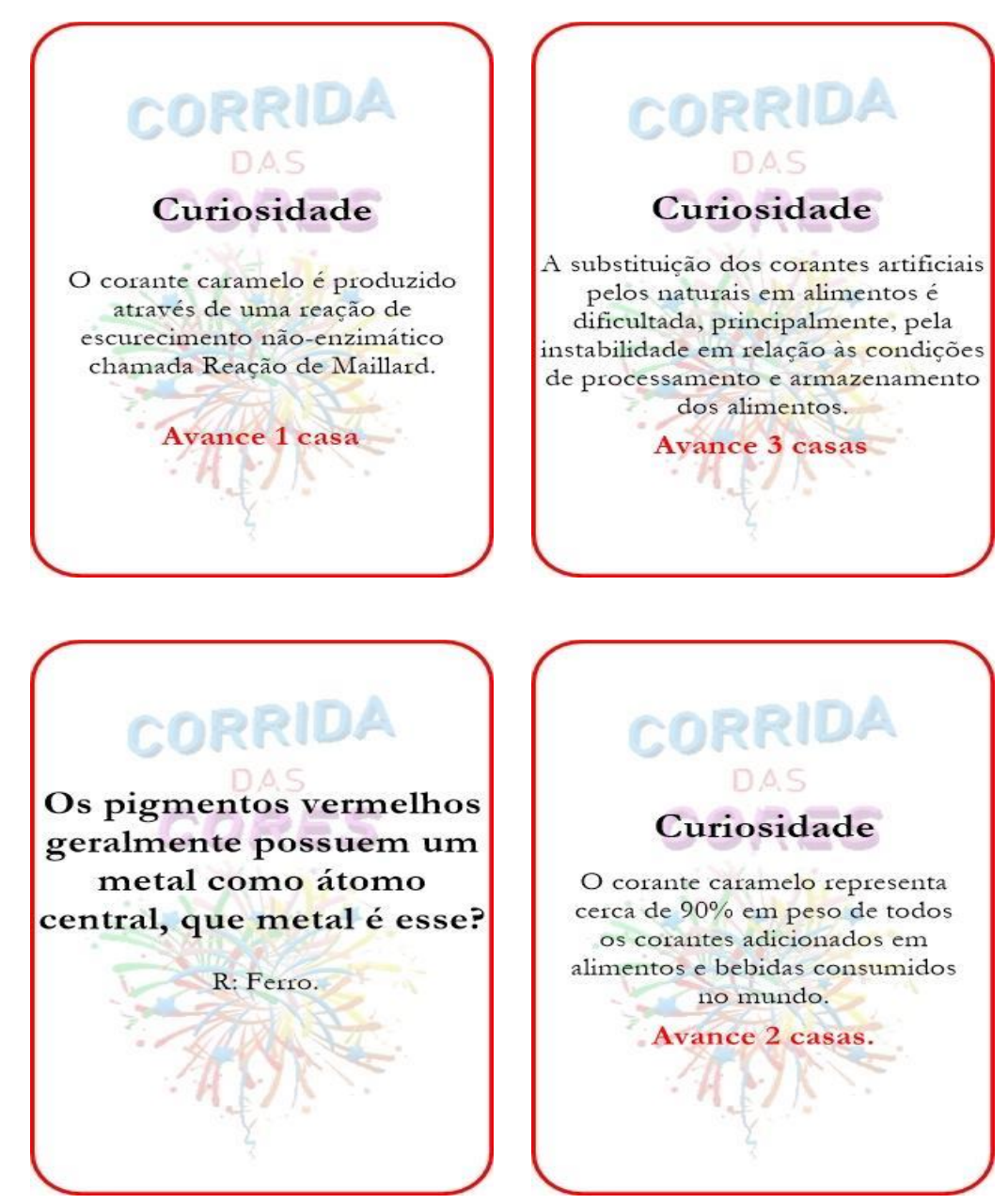

O corante caramelo representa cerca de $90 \%$ em peso de todos

os corantes adicionados em alimentos e bebidas consumidos no mundo.

Avance 2 casas.
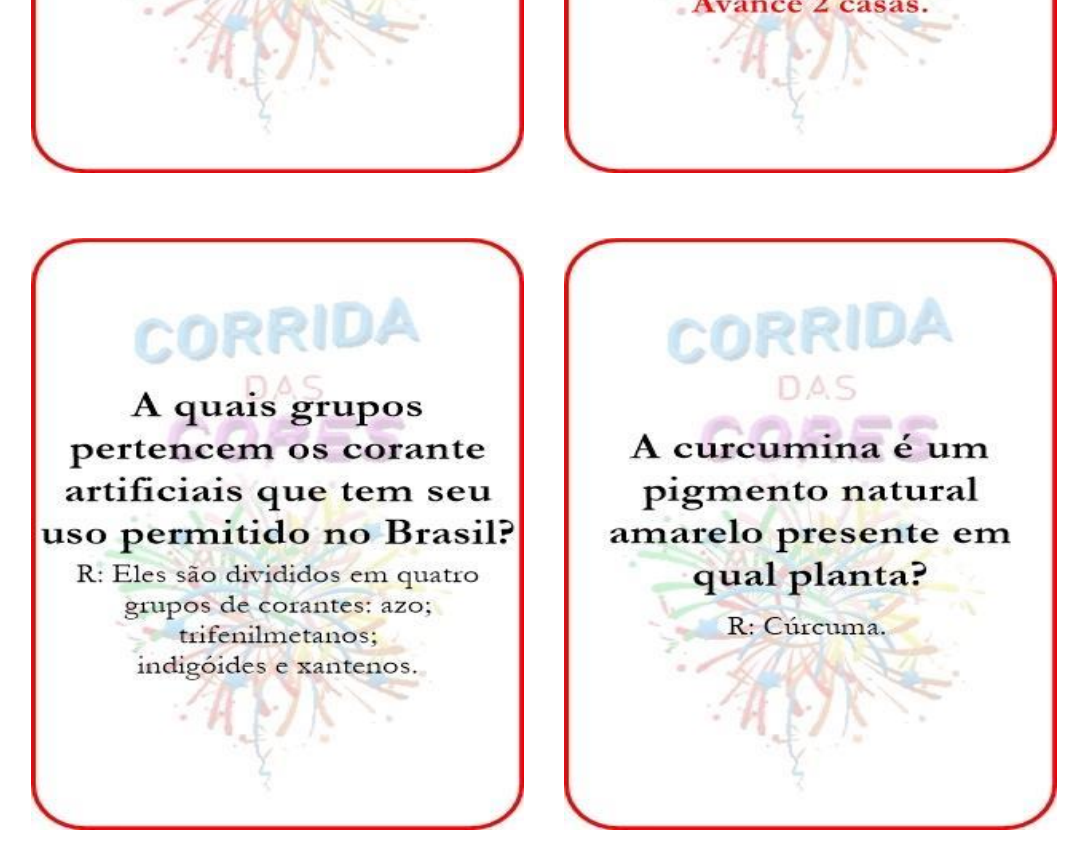


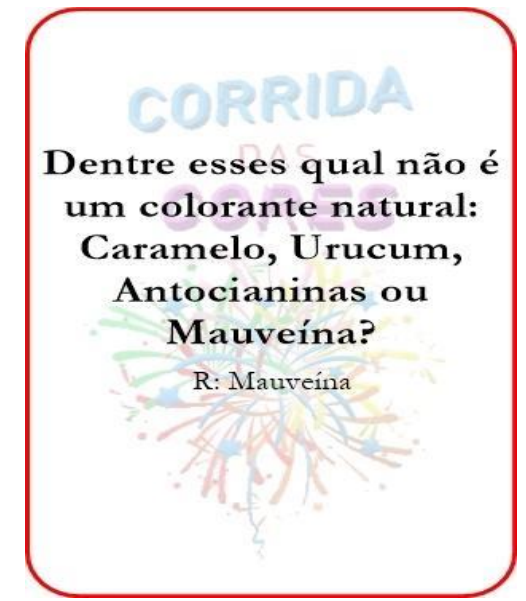

Qual o fator de maior interferência na coloração

das antocianinas?

$\mathrm{R}$ : $\mathrm{O} \mathrm{pH}$ é certamente o fator mais importante no que diz respeito à coloração das antocianinas. Elas tornam-se estáveis e assumem a forma colorida (cátion flavilium) somente em solução bastante ácida.

Qual a origem do nome do Brasil?

$\mathrm{R}$ : Nosso país recebeu este nome porque nos primeiros anos de sua colonização era retirada das matas na costa brasileira a madeira da

Caesalpinia echinata, chamada popularmente de pau-brasil. Desta madeira era extraida uma resina de cor vermelha cor-de-brasa, Brasil, que era usada para tingir tecidos.
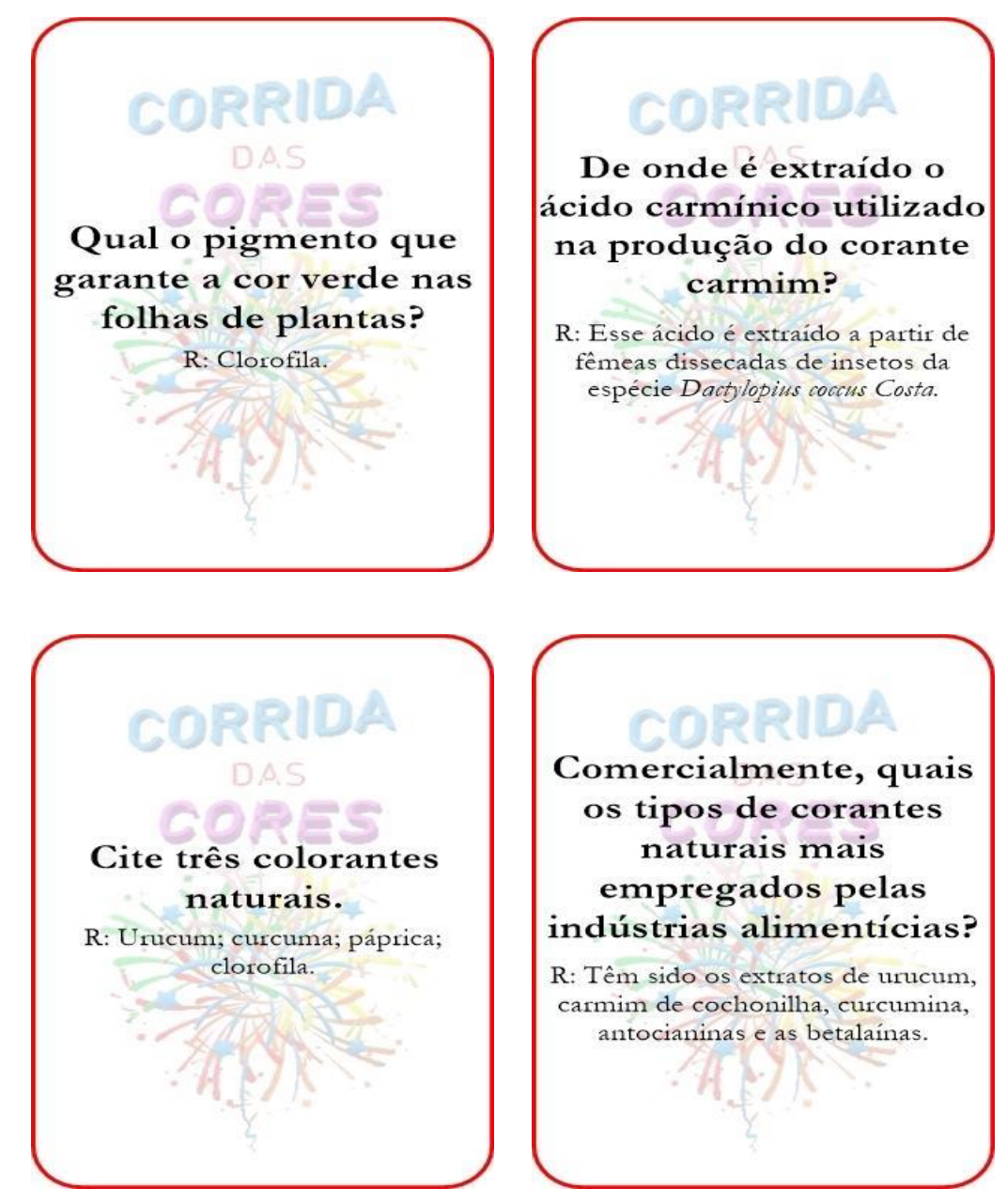

Comercialmente, quais os tipos de corantes naturais mais empregados pelas indústrias alimentícias?

R: Têm sido os extratos de urucum, carmim de cochonilha, curcumina, antocianinas e as betalainas. (n)
Cite pelo menos cinco corantes alimentícios artificiais que tem seu uso permitido no brasil?

R: Amaranto; Vermelho de Eritrosina; Vermelho 40; Ponceau 4R; Amarelo

Crepúsculo; Amarelo Tartrazina;

Azul de Indigotina; Azul Brilhante; Azorrubina; Verde Rápido e Azul Patente V. 

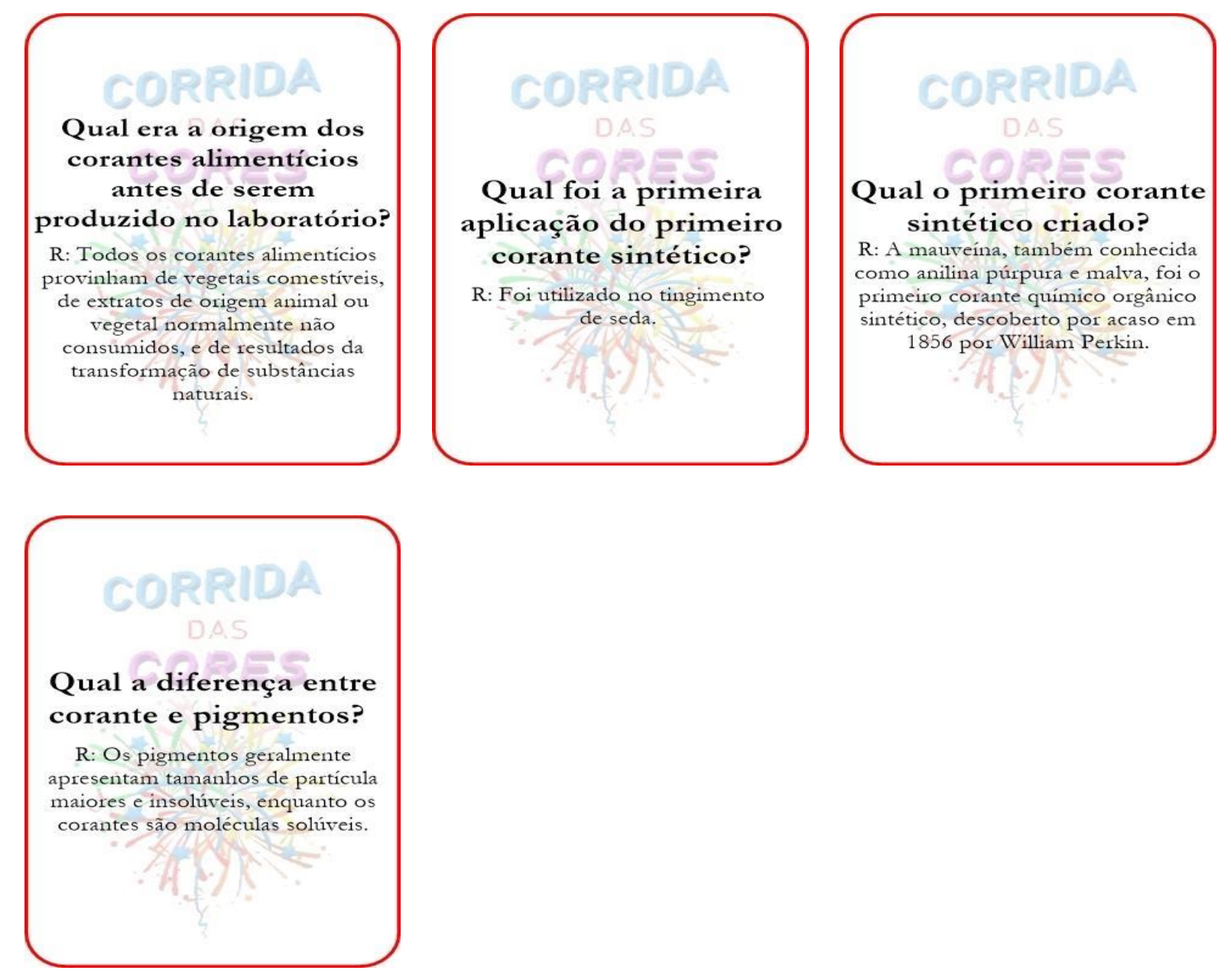


\section{CARTAS DESAFIO}
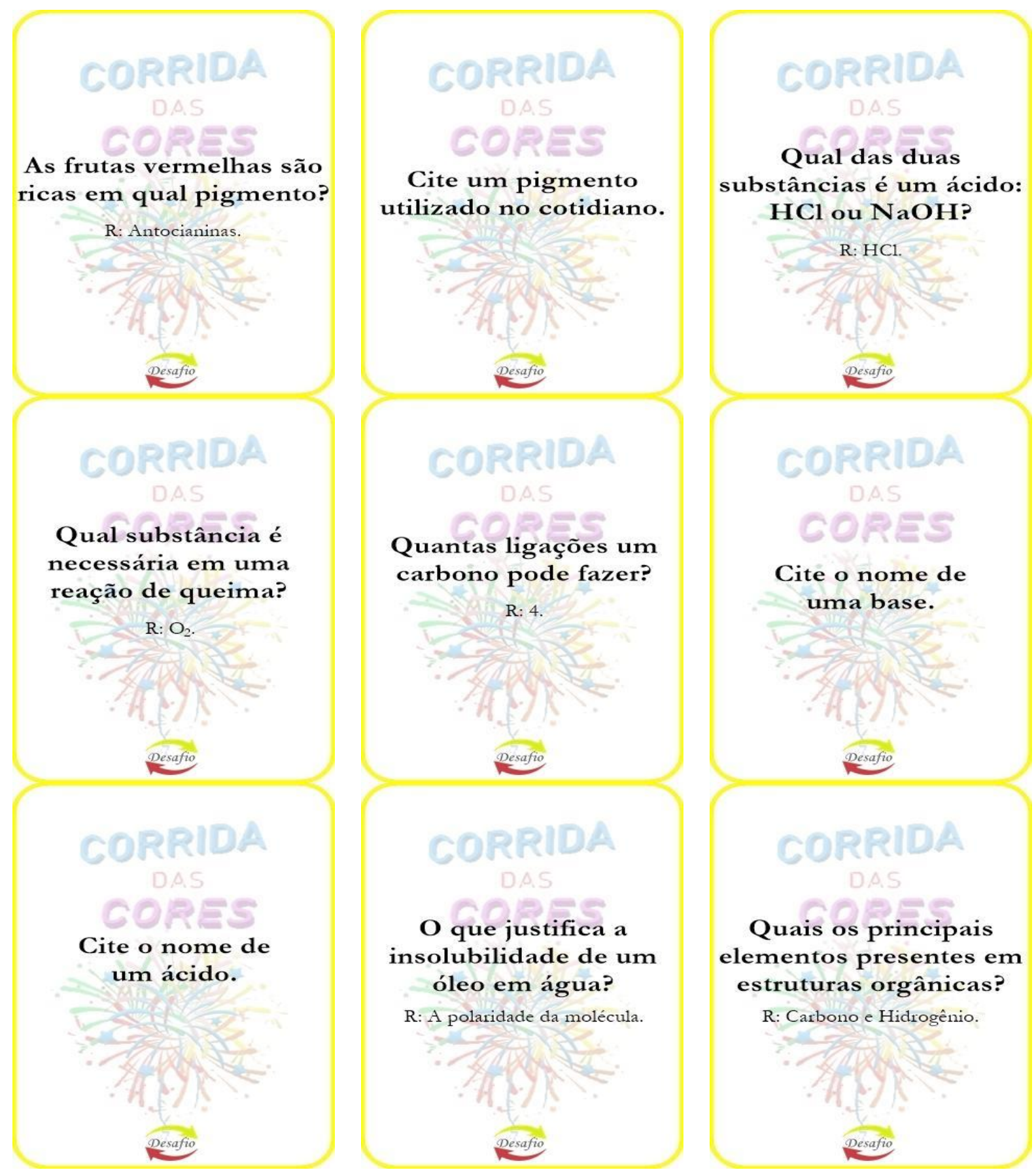


\section{TABULEIRO}

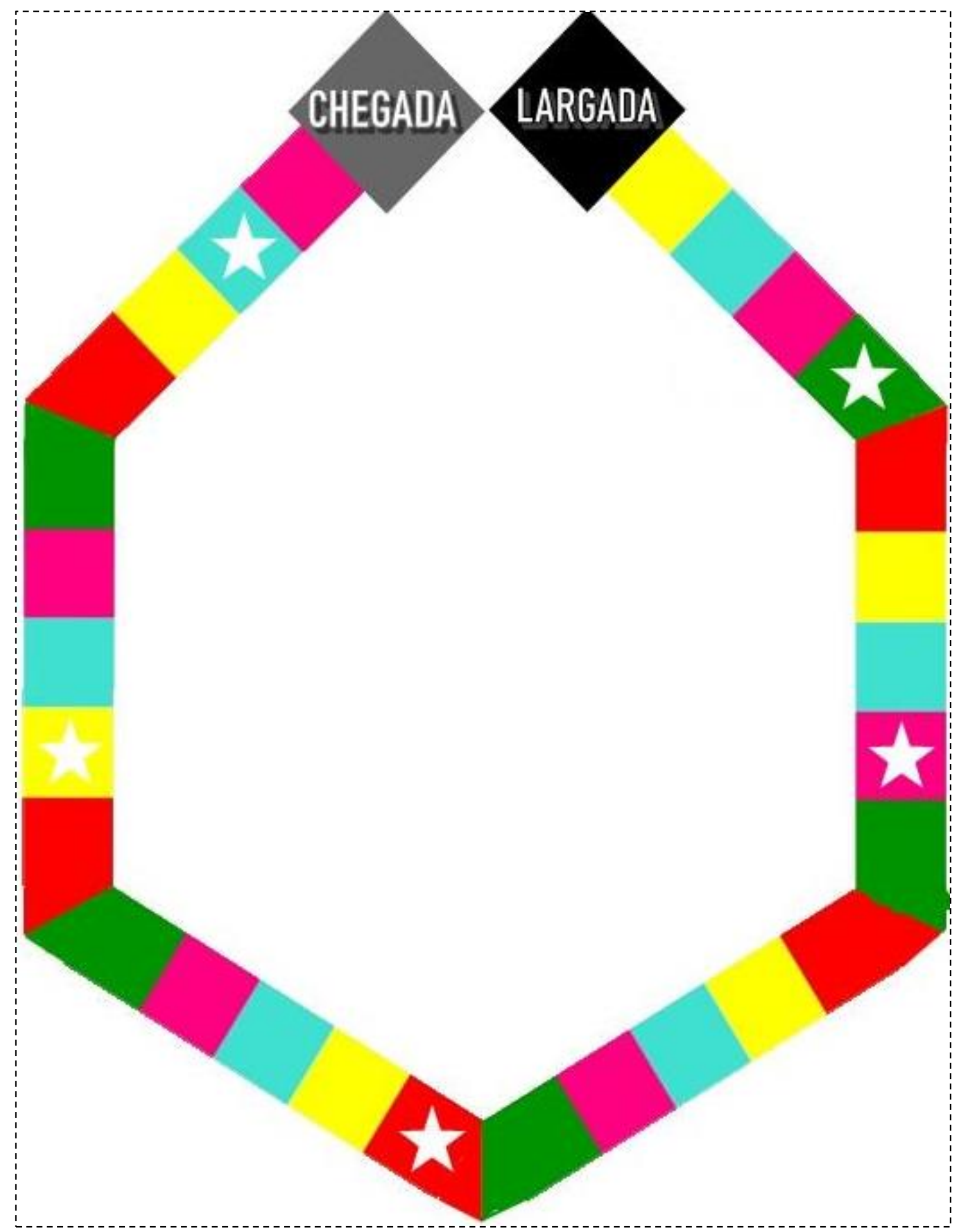

Figura 3: Tabuleiro 


\section{REFERÊNCIAS BIBLIOGRÁFICAS}

[1] ARAÚJO, J. M. A. Química dos Alimentos- Teoria e Prática. 4ª ed. Viçosa, MG: Ed. UFV, 2008. 596p.

[2] CARDOSO, S. L. FOTOFÍSICA DE CAROTENÓIDES E O PAPEL ANTIOXIDANTE DE $\beta$-CAROTENO. Química Nova, [s. l], v. 20, n. 5, p. 535-540, 1997.

[3] COUlTATE, T. P. Alimentos: A quimica de seus componentes. $3^{3}$ ed. Porto Alegre: Artmed, 2004.368p.

[4] CRIZEL, R. L. Prospecção de pigmentos produzidos por cochonilhas Ceroplastesspp. para aplicação em alimentos. 2017. 62 f. Dissertação (Mestrado) Curso de Ciência e Tecnologia de Alimentos, Universidade Federal de Pelotas, Pelotas, 2017.

[5] DAMODARAN, S.; PARKIN, K. L.; FENNEMA, O. R. Quimica de Alimentos de Fennema. 4a ed.Porto Alegre: Artmed, 2010. 900p.

[6] FABRI, E. G.; TERAMOTO, J. R. S. Urucum: fonte de corantes naturais. Horticultura Brasileira, [S.L.], v. 33, n. 1, p. 140-140, mar. 2015. FapUNIFESP (SciELO). http://dx.doi.org/10.1590/s0102-053620150000100023.

[7] INSTITUTO BRASILEIRO DE DEFESA DO CONSUMIDOR. Você sabe o que é Caramelo IV? Disponível em: https://idec.org.br/consultas/dicas-e-direitos/voce-sabeo-que-e-caramelo-iv. Acesso em: 05 out. 2020.

[8] LOPES, R. M.; OLIVEIRA, T. T. de; NAGEM, T. J.; PINTO, A. da S. Farmacologia de flavonóides no controle hiperlipidêmico em animais experimentais. Biotecnologia Ciência \& Desenvolvimento, [s. l], v.17, p. 18-22, 2000.

[9] MUCCIOLO, P.; BARBUTO, O.; CAMPOS, M. M.. TEOR DE VITAMINA A E CAROTENO EM MANTEIGAS CONSUMIDAS EM SÃO PAULO. Rev. Fac. Med. Vet., São Paulo, v. 5, n. 3, p. 551-561, 1995.

[10] OLIVEIRA, V. P. de; ESPESCHIT, A. C. R.; PELUZIO, M. do C. G.. FLAVONÓIDES E DOENÇAS CARDIOVASCULARES: AÇÃO ANTIOXIDANTE. Rev Med Minas Gerais, [s. l], v. 16, n. 4, p. 234-238, 2006.

[11] PRADO, M. A.; GODOY, H. T. CORANTES ARTIFICIAIS EM ALIMENTOS. Alim. Nutr., Araraquara, v.14, n.2, p. 237-250, 2003

[12] PRADO, M. A.; GODOY, H. T. Corantes artificiais em alimentos. Alimentos e Nutrição Araraquara, v. 14, n. 2, 2009.

[13] ROCHA, D. S.; REED, E. Pigmentos naturais em alimentos e sua importância para a saúde. Estudos, Goiânia, GO, v. 41, n. 1, p. 76-85, jan./mar. 2014.

[14] SILVA, A. P. da; LIMA, C.L.C. de; VIEITES, R. L.; CARACTERIZAÇÃO QUÍMICA E FÍSICA DO JENIPAPO (Genipa americana L.) ARMAZENADO. Scientia Agricola, [S.L.], v. 55, n. 1, p. 29-34, jan. 1998. FapUNIFESP (SciELO). http://dx.doi.org/10.1590/s010390161998000100006. 
[15] STREIT, N. M.; CANTERLE, L. P.; CANTO, M. W. do; HECKTHEUER, L. H. H. As clorofilas. Ciência Rural, [S.L.], v. 35, n. 3, p. 748-755, jun. 2005. FapUNIFESP (SciELO). http://dx.doi.org/10.1590/s0103-84782005000300043.

[16] TEIXEIRA, L. V. ANÁLISE SENSORIAL NA INDÚSTRIA DE ALIMENTOS. Rev. Inst. Latic, [s. l], v. 366, n. 64, p. 12-21, 2009. 


\section{Jogo 8}

\section{Memória em cores}

João Vitor Araújo Souza

Layonara Dhuly da Silva Teixeira

Maria da Conceição Tavares Cavalcanti Liberato 


\section{INTRODUÇÃO}

As cores são um aspecto essencial para percepção de prazeres, elas são uma característica estética que abrange toda a nossa percepção do mundo. Com a alimentação não é diferente, os alimentos possuem cores que se associam a sabores e outras características (CREPALDI, 2006; TEIXEIRA, 2009).

Com o desenvolvimento da engenharia de alimentos a química iniciou o processo de manipulação das cores com corantes, sejam naturais ou sintéticos, e com a alta dos alimentos industrializados a predominância do uso de corantes artificiais se tornou realidade, pois estes apresentam alta estabilidade e um menor custo à indústria em relação aos pigmentos naturais. Dessa forma o consumo deles acontece de forma inconsciente e inconsequente (SOUZA, 2012).

Assim, a autonomia alimentar é investida com o fundamento de promover uma consciência no consumo. No Brasil, a Agência Nacional de Vigilância Sanitária (ANVISA) determina valores máximos de ingestão diária desses corantes artificiais, a fim de minimizar possíveis danos à saúde. Dessa forma, garantir o conhecimento e permitir a associação do alimento às suas composições químicas é essencial para reforçar a alimentação um ato de saúde e distanciar o alto consumo de substâncias tóxicas e maléficas (MARTINS, 2014; RODRIGUES, 2015).

O jogo da memória desenvolvido permite a associação dos corantes e pigmentos presentes em alimentos comuns do cotidiano de forma dinâmica para os alunos, possibilitando que os alunos desenvolvam autonomia e consciência da alimentação e seus impactos no organismo.

\section{INSTRUÇÕES}

O jogo da memória pode ser jogado por uma ou mais pessoas, o jogo é composto por 20 peças, 10 nomes de corantes ou pigmentos e 10 alimentos que são compostos por eles. 0 objetivo do jogo é encontrar o alimento e seu respectivo pigmento.

Inicie o jogo colocando todas as cartas viradas para baixo. Cada jogador deve fazer uma jogada por vez. Vire duas cartas para cima, fazendo com que todos jogadores possam ver. Se as cartas corresponderem retire-as do jogo e marque um ponto, caso elas não correspondam volte-as à mesma posição que estavam.

Quando todos os pares forem encontrados o ganhador será o jogador que achou mais pares de imagens. 

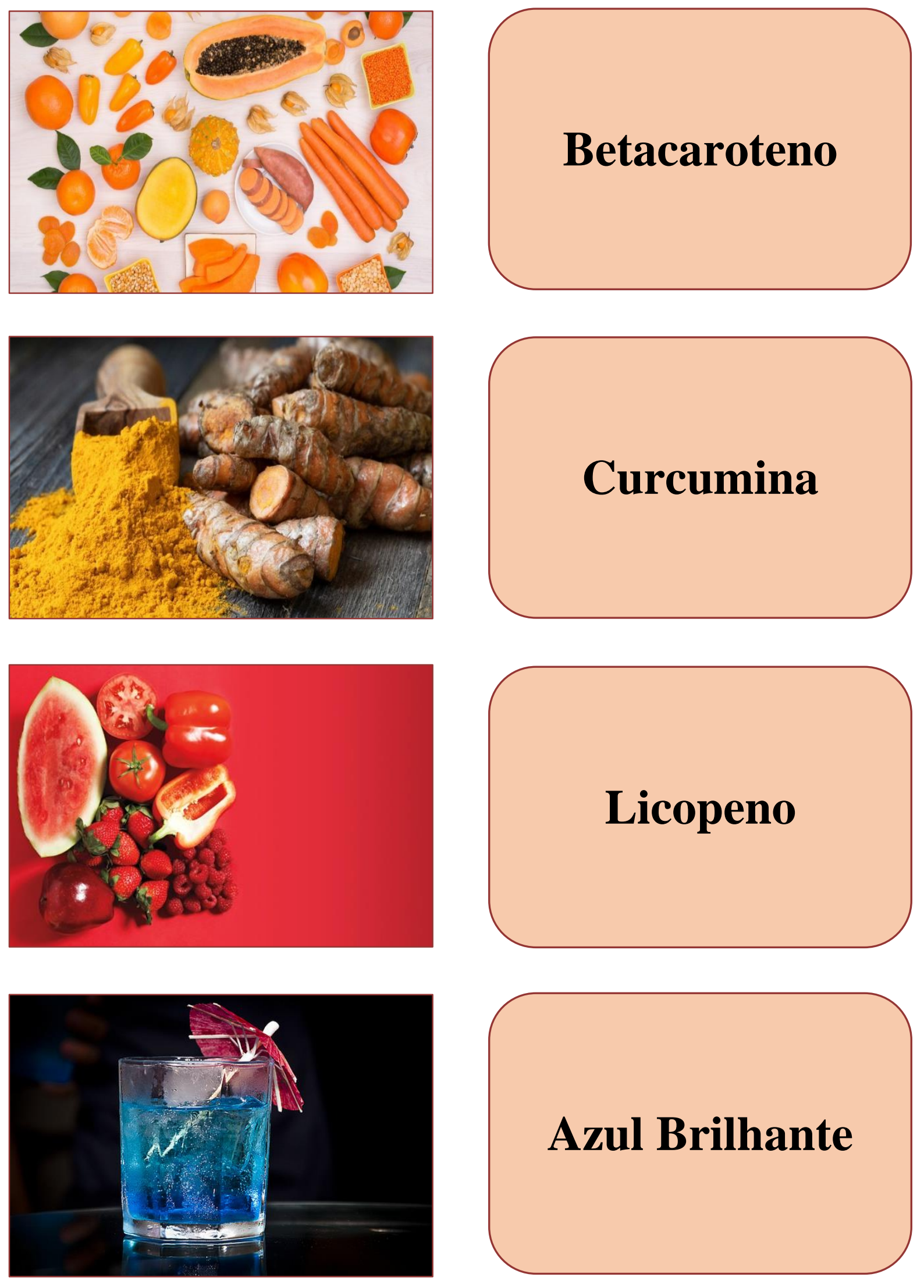

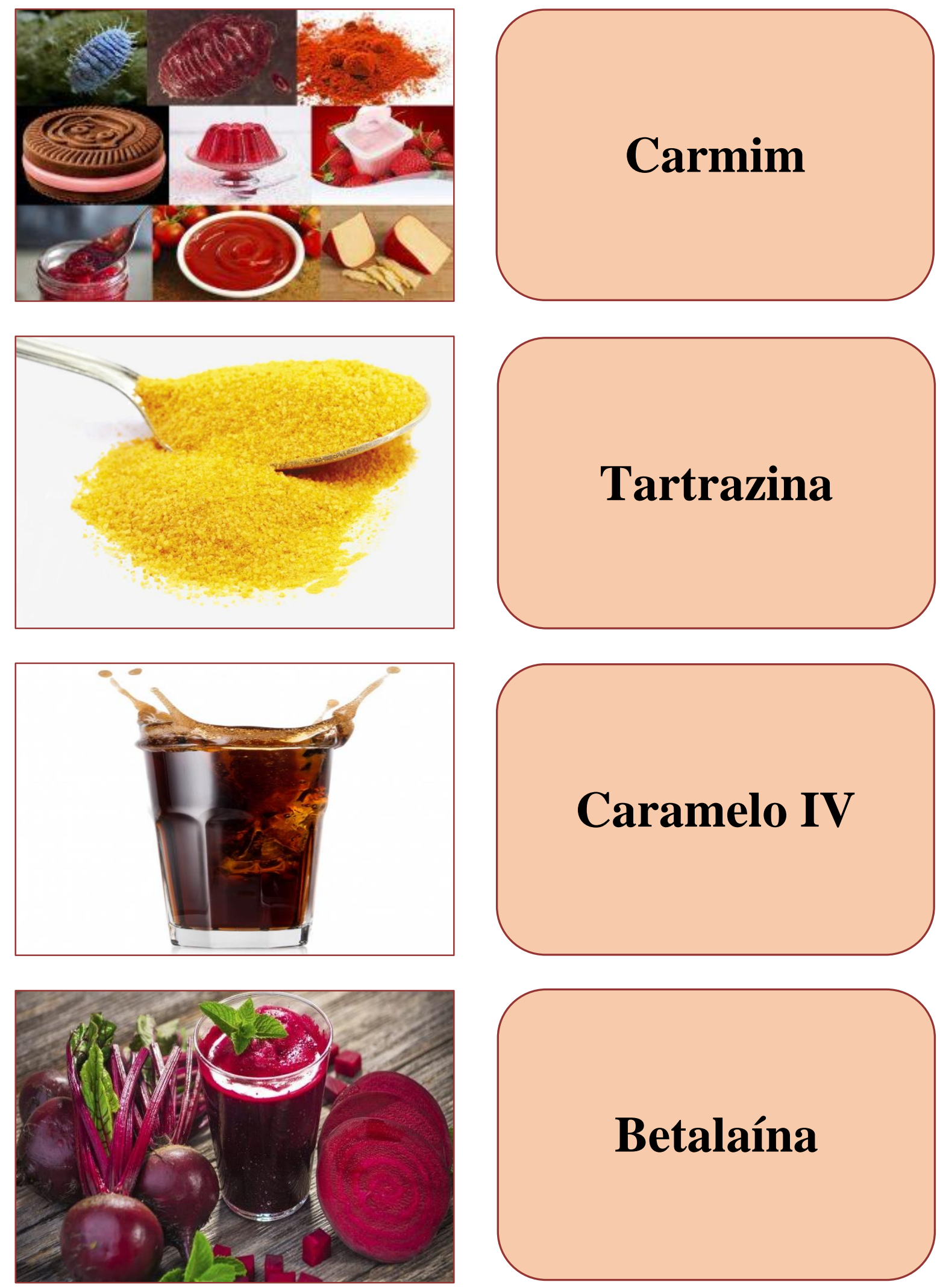

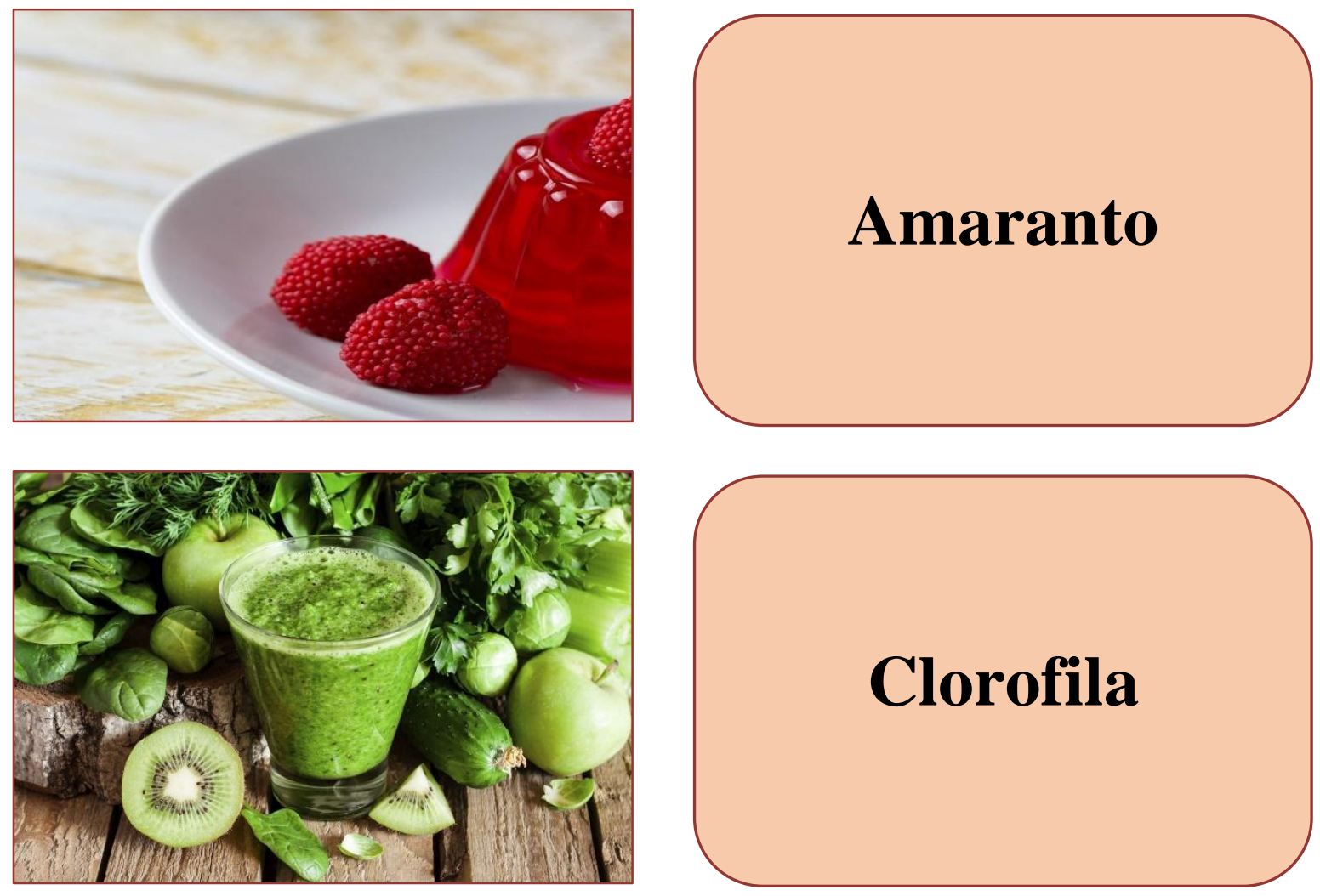


\section{REFERÊNCIAS}

[1] FARINA, M. Psicodinâmica das cores em comunicação. 2ł. ed. São Paulo: Edgard Blücher, 1986.

[2] KISHIMOTO, T. M. Jogo, brinquedo, brincadeira e a educação. São Paulo: Cortez, 1996.

[3] NETTO, R. C. M. Dossiê corantes. FOOD INGREDIENTS BRASIL, n. 9, 2009. Disponível em: . Acesso em: 13 de. sept. 2020 .

[4] POLONI, R.; LUCA, M. Corantes naturais frentes às tendências mundiais. Periódico Tchê Química, v. 4, n. 7, p. 33-40, Porto Alegre, 2007. Disponível em:<http://www.deboni.he.com.br/tq/revista/revista7.htm> Acesso em: 13 de. sept. 2020 .

[5] SOUZA, R. M. CORANTES NATURAIS ALIMENTÍCIOS E SEUS BENEFÍCIOS À SAÚDE. 2012. Monografia (Graduação Farmácia), Centro Universitário Estadual da Zona Oeste, Rio de Janeiro, 2012. Orientador: Professor Marco Antônio Mota e Professora Sabrina da Silva Dias.

[6] VELOSO, L. A. Corantes e Pigmentos - Dossiê Técnico. Serviço Brasileiro de Respostas Técnicas. Instituto de Tecnologia do Paraná, 2012. 


\section{Jogo 9}

\section{Trilha}

Kaio Medeiros Teles Cavalcante

Liz Roberta Silva Lima

Everson da Silva Gomes

Caio Santos Cabral

Maria da Conceição Tavares Cavalcanti Liberato 


\section{INTRODUÇÃO}

As antocianinas fazem parte da classe dos flavonóides, pigmentos naturais, que são responsáveis por uma variedade de cores atrativas das flores, folhas e frutas, que variam do vermelho ao azul. São componentes de muitas frutas vermelhas e hortaliças escuras, com grande concentração nas cascas de uvas escuras (VOLP et al., 2008)

0 jogo foi confeccionado para auxiliar de maneira dinâmica a abordagem deste trabalho de reconhecer as antocianinas. Sendo repleto de perguntas que traz diversas curiosidades proporcionando maior interação e desafiando o conhecimento

\section{INSTRUÇÕES}

1ํ) São necessários dois ou mais jogadores.

$2^{\text {o) }} 0$ dado é jogado para definir a ordem dos participantes.

$3^{\text {o) }}$ Cada jogador jogará o dado para definir o número de casas que irá avançar.

$4^{\circ}$ ) Ao parar na casa indicada o jogador deverá responder a uma pergunta sorteada por seu adversário do baralho de perguntas. Se o jogador não responder corretamente à pergunta, deverá ficar uma rodada sem jogar.

5ำ) 0 jogador também encontrará no tabuleiro figuras com instruções específicas sobre sua natureza.

Solução azul = Avance uma casa

Solução vermelha = Fique uma rodada sem jogar

Ganhará quem chegar primeiro ao fim do tabuleiro 
CARTAS

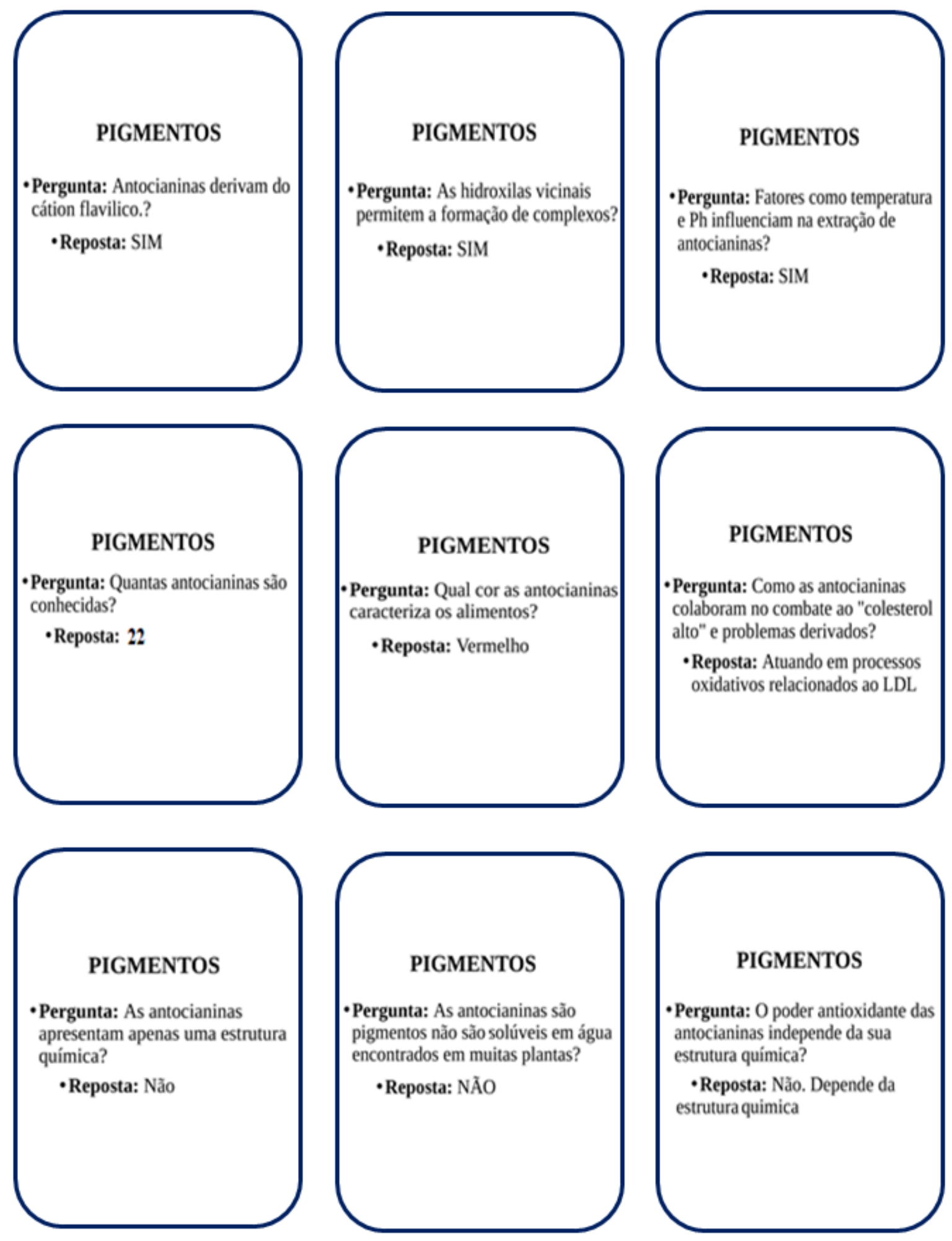




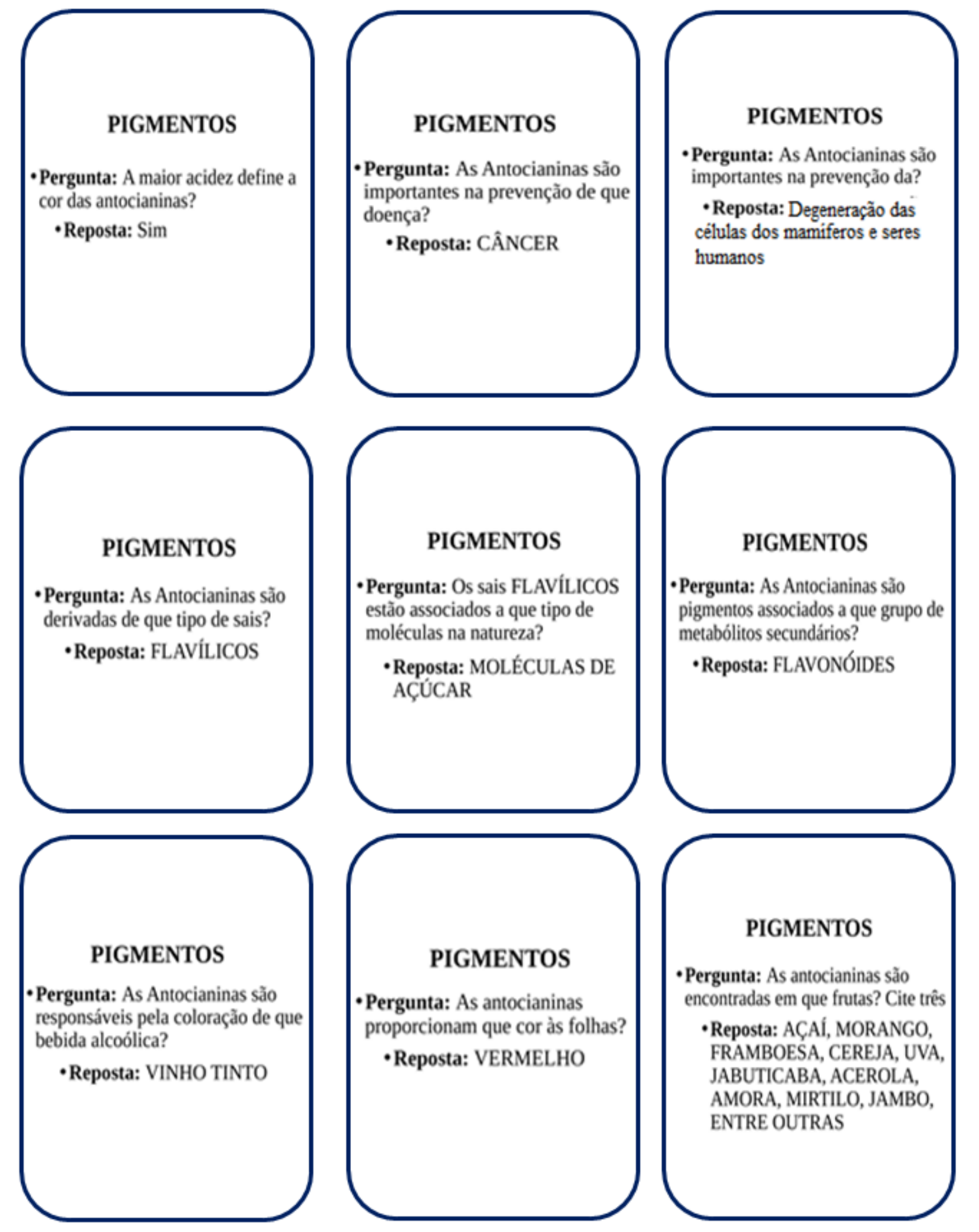




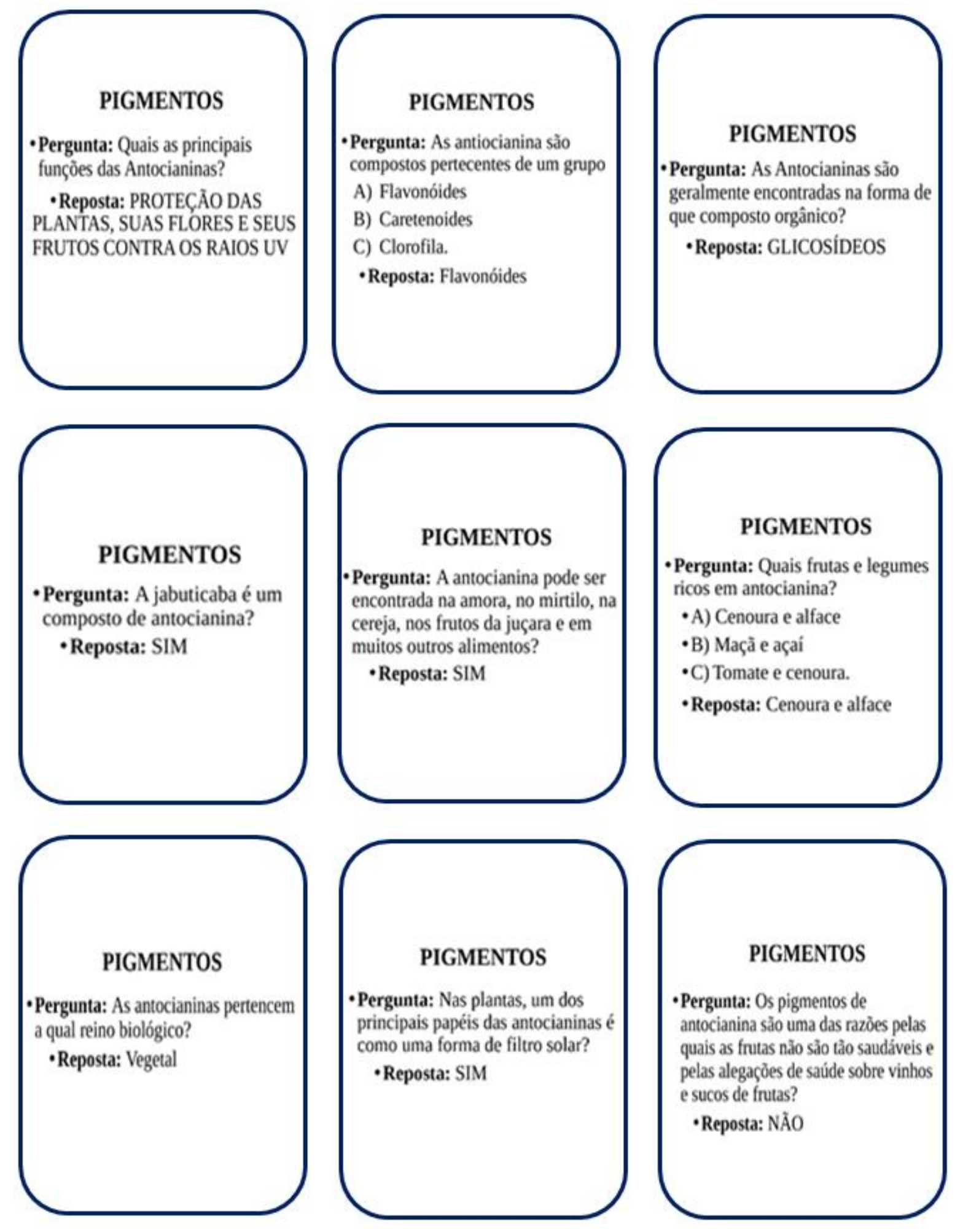



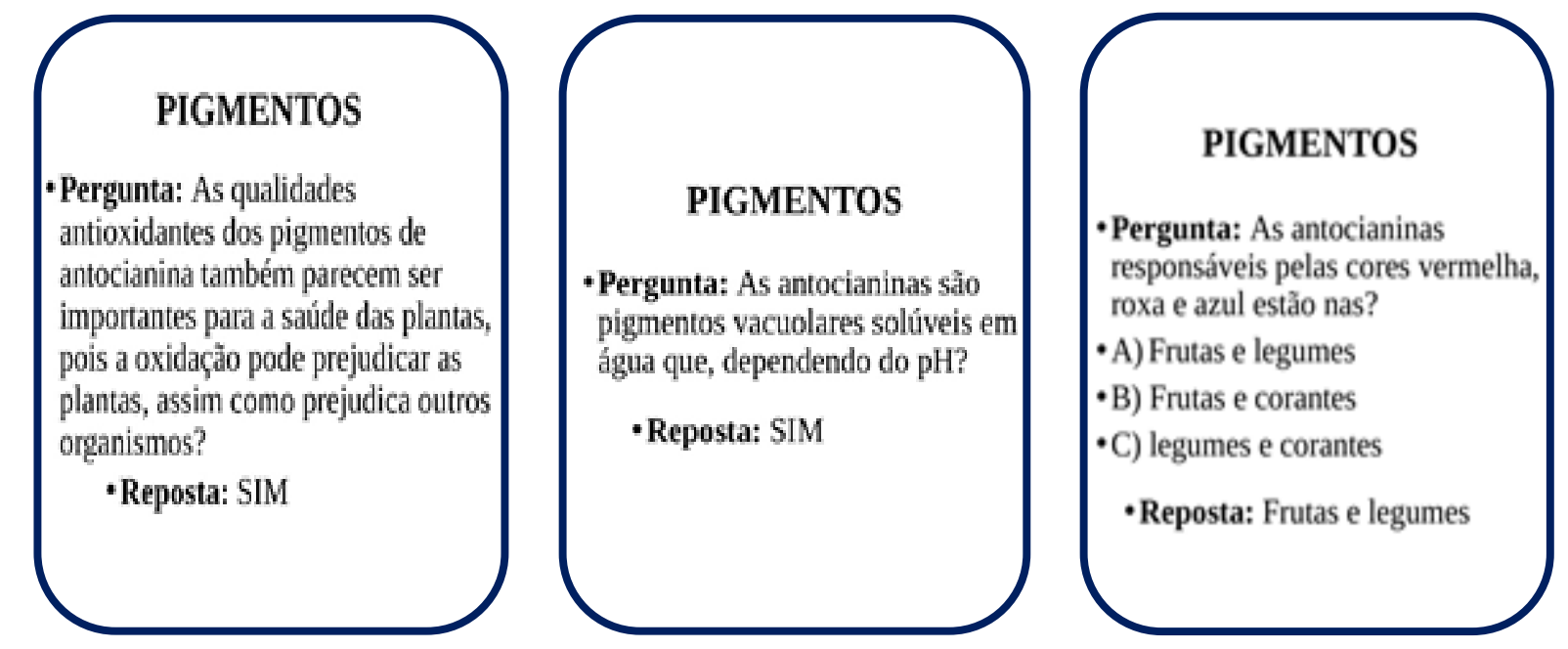


\section{TABULEIRO}

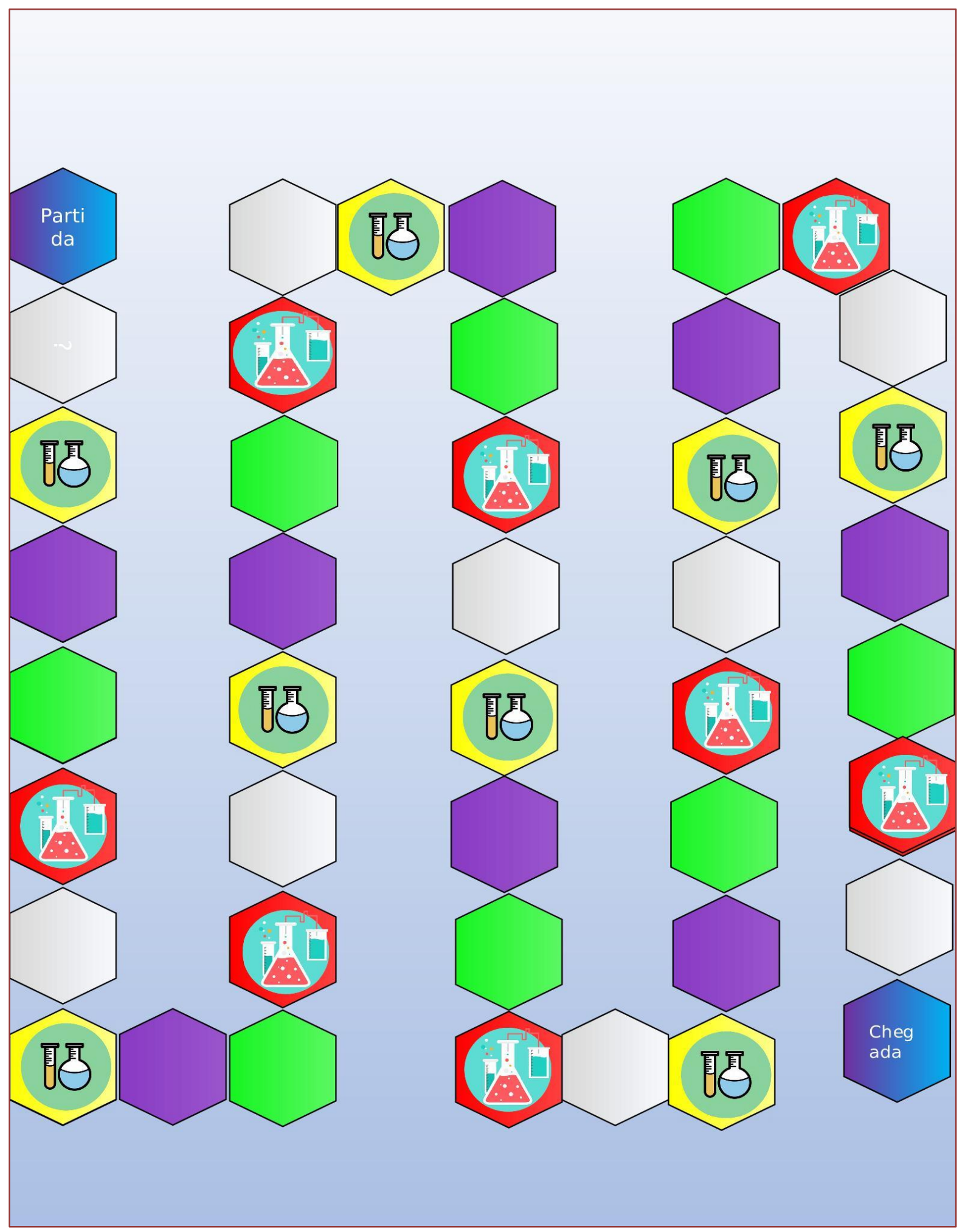




\section{REFERÊNCIAS}

[1] VOLP, A. C. P.; RENHE, I. R. T.; BARRA, K.; STRIngueTA, P. C. Flavonóides antocianinas: características e propriedades na nutrição e saúde. Revista Brasileira de Nutrição Clinica vol. 23, n. 2, p. 141-149, 2008.

[2] Cardoso, L.M; Leite, J.P.V.; Peluzio, M.C.G, Efeitos biológicos das antocianinas no processo aterosclerótico, Re.Colomb.Cien.Quím.Farm, Vol.40(1), 116-138, 2011. 


\section{Jogo 10}

\section{Investigador}

Dayanne Cipriano Costa da Silva

Maria da Conceição Tavares Cavalcanti Liberato 


\section{INTRODUÇÃO}

Embora o consumo de um determinado alimento devesse depender principalmente do seu valor nutricional, a sua cor, aroma e textura são fatores que conduzem à preferência do consumidor (BOBBIO, BOBBIO, 1995).

Na prática podemos perceber a preferência dos consumidores por alimentos de cores vivas, razão pela qual as empresas de alimentos se preocupam tanto com a coloração final do seu produto. As cores conferem ao nosso olhar um prazer imediato, de fato, alimentos de cores fortes parecem mais saborosos e saudáveis. Os corantes são uma classe de compostos orgânicos amplamente utilizados nos mais variados setores industriais. Para promover o conhecimento sobre os diferentes tipos de corantes foi criado o jogo, investigador. 0 jogo é motivador, dinâmico e faz com que os alunos melhorem o raciocínio assim como outras competências, essa ferramenta faz com que os alunos busquem trabalhar as relações sociais e individuais como: trabalhar em equipe, compartilhar conhecimentos, tomar decisões e respeitar regras. (SÁ et al., 2006).

\section{MATÉRIAS E MÉTODOS:}

Através do conhecimento previamente estabelecido, sobre corantes naturais e artificias foi montado um jogo inspirado no DETETIVE (jogo da estrela, empresa de entretenimento). 0 jogo conta com oito avatares e duas cenas de crime, onde através das provas pode-se chegar ao culpado. As provas na cena, estão diretamente ligadas as propriedades dos corantes logo, para achar o culpado, o jogador terá que montar uma linha de pensamento, associando seu conhecimento sobre corantes e os fatos observados na cena do crime.

Objetivo: Encontrar o culpado

Número de jogadores: de 2 a 8 pessoas

\section{Guia do jogo:}

1. Escolhe-se o chefe da mesa ou supervisor do caso.

O supervisor é responsável por:

1.1 Ler o texto de introdução sobre o crime

1.2 Dar as pistas

1.3 Escolher, em caso de empate, quem foi o melhor investigador, logo ganhador. 


\section{Atenção:}

$\checkmark$ Cabe somente ao supervisor saber a identidade do culpado.

$\checkmark \underline{0 \text { chefe de caso não deve dar mais pistas ou qualquer ajuda fora do limite }}$ prescrito.

2. 0 chefe da mesa sorteia o crime da rodada, em seguida mostra aos investigadores (jogadores da mesa), lendo o texto base do crime.

3. Logo após a exposição do caso o supervisor deve ler o relatório base de cada suspeito.

4. Em seguida, o chefe da mesa deve de ler a primeira prova, e pedir, em seguida, que cada investigador faça sua indicação sobre quem é o culpado.

\section{Atenção:}

$\checkmark \quad$ A cada investigador é dado a oportunidade de mudar o culpado apenas UMA VEZ após o início.

Observação: Aposta inicial (Tópico 4) não conta como tentativa.

5. Agora, cada investigador tem o direito à três evidências, logo em seguida deve apontar o culpado.

6. As evidências serão distribuídas, para cada jogador, dessa forma:

$\checkmark \quad 0$ investigador deve jogar os dados (opcional para cada jogador, jogar um, dois ou três dados).

$\checkmark \quad 0$ número correspondente ao resultado, será sua evidência. (o supervisor deve passar a ficha para o investigador lhe dando um tempo limite com ela).

Observação: Fica a critério do supervisor dizer o tempo limite, podendo variar de: um a dois minutos.

$\checkmark$ A cada evidência o investigador tem direito de apontar o culpado ou não.

$\checkmark$ Somente na terceira evidência o investigador é obrigado a apontar o culpado.

Observação: Na folha de anexo também estão contidas: perguntas, bonificações e punições.

7. Uma vez que o investigador apontar o culpado, se estiver certo é VENCEDOR, caso esteja errado é desclassificado

Observação: Para os avatares, tanto para os suspeitos quanto para o investigador, podem ser feitos com somente um nome ou desenhos caso o professor ou mediador prefira. 


\section{ANEXOS}

Anexo 01:Cena 01 e 02 dos crimes.

Anexo 02: Folha de evidências 01 e 02.

\section{ANEXO 01}

Texto base para a cena de crime 01

Em uma mansão na cidade de Fortaleza-Ce durante uma festa, ocorreu um homicídio, a vítima caiu aos olhos de todos no salão, logo foi chamado o pronto socorro, porém nada pode-se fazer, assim foi declarado o óbito da vítima:

Vítima: Marcos Fortamet Vieira

Idade: 40 anos

$\checkmark$ O Sr. Fortamet era dono de uma grande rede de empresas de alimentos, onde ao longo de sua vida ganhou milhões e também vários inimigos.

$\checkmark$ A festa era para comemorar o sucesso de 15 anos de suas empresas no mercado e o fechamento de um negócio milionário.

$\checkmark$ De temperamento rústico e agressivo o Sr. Fortamet gostava de ter todo poder e mostrar que o tinha. Para festa foi convidado: Sua Ex mulher, Concorrentes de mercado e alguns de seus desafetos familiares.

\section{Dica 01:}

\section{Dados do legista:}

Causa da morte: Choque Anafilático

Choque Anafilático: Reação alérgica grave e possivelmente fatal. A reação pode ocorrer segundos ou minutos depois da exposição a um alérgeno.

Exame do Corpo: Foi encontrado irritação na pele, hemorragia interna. 


\section{Texto base para cena do crime 02}

Em uma casa na cidade de São Paulo-SP, é encontrado um corpo, ela manhã, de uma jovem caída em sua cozinha. No cômodo foi encontrado taças de vinho e pratos, o que será que ocorreu naquela noite?

Vitima:Paolla Juliete Silva

Idade: 27 anos

$\checkmark$ Segunda a testemunha que achou o corpo, Paolla teria dado uma social em sua casa.

$\checkmark$ Muito simpática e gentil. Frequentemente, aos finais de semana, sua casa estava cheia de pessoas.

$\checkmark$ Segundo o vizinho Paolla teria discutido com o namorado na noite passada

$\checkmark \quad 0$ apartamento estava fechado por dentro.

\section{Dica 01:}

\section{Dados do legista:}

Causa da Morte: Envenenamento e trauma por pancada na cabeça.

Exame do Corpo: Hematoma na cabeça, Suco intestinal com alto nível de uma toxina solúvel em solventes polares. 


\section{ANEXO 02}

\section{Evidências do caso 01}

01.No exame de sangue foi observado colesterol alto, o que indica que a vítima tinha um mal habito alimentar.

02.No exame de sangue foi detectado a presença de um corante de coloração amarelada, cor semelhante ao da bebida que a vítima consumia na noite. 0 corante é solúvel em água.

03.A vítima era apaixonada por doces e salgadinhos, em especial os processados.

04.Antes do acontecimento foi ao médico relatando vermelhidão na pele, vômito e dificuldade para respirar e comer.

05. Sr,Fortamet tinha alergia há comidas que possuem corantes caramelos..

06.passe sua vez.

07.Indique alguém para ficar uma rodada sem jogar.

08.Investigadores trabalham melhor em grupo, aponte outro investigado para lhe dizer todas as suas informações.

09. Tem momentos na investigação que se torna impossível chegar à uma conclusão sozinha(o), logo indique alguém para jogar com você até o final do jogo.

$\checkmark$ Os dois jogadores apesar de jogarem em dupla, devem ser tratados como um só, ou seja, terão direito apenas um chute fora ao inicial.

As evidências de ambos devem ser unidas e subtraídas do valor limite (ou seja, se as evidências totalizarem três ou mais, estes já terão que dizer o seu suspeito final)

Se a soma das evidências totalizarem um valor inferior ao número limite, os investigadores devem conversar e descarta um dos suspeitos escolhidos inicialmente no jogo.

10.Na cozinha foram encontrados vários alimentos processado, temperos exóticos e três fracos com substâncias desconhecidas:

Substância 01 :corante a base de urucum.

Substância 02: corantes amarelo de solubilidade em água fria e gordura.

(a vítima tinha um apreço por esse tempero chegando a consumi-lo, pelo menos duas vezes a cada dia, durante anos).

Substância 03:Também de coloração amarelada, porém insolúvel em água ou solvente polares

(cozinheiro informou não saber de onde esse frasco surgiu).

11.Não foi o cozinheiro, para solucionar o caso você terá que prestar atenção nos hábitos alimentares da vítima, o assassino é quem você menos espera. 
12.Você sabia que algumas doenças ou consequências relacionadas a nossos hábitos alimentares podem demorar anos para aparecer? Observe bem.

13.Na noite anterior ao crime, a ex mulher da vítima teria discutido com ele.

14.Na manhã do ocorrido o Sr.fortamet teria recebido uma ligação de um de seus concorrentes lhe ameaçando.

15.No copo da vítima foram encontradas as digitais: da vítima, ex mulher, garçom e do cozinheiro.

16.No balcão da cozinha foi encontrado traços e uma substancia de cor amarelo intenso, solúvel em água fria e gordura.

17.0 Sr.Fortamet era um homem que tinha problemas com todos na sala, em especial com sua família, no mês anterior jurou deserdar seu filho.

18.Pergunta BÔNUS:

$\checkmark$ Qual a diferença entre pigmentos e corantes?

$\checkmark$ Se ACERTAR jogue novamente.

$\checkmark$ Se errar deixe de jogar por DUAS rodadas.

19.De exemplo e corantes naturais.

\section{Solução do caso 01:}

O assassino é sua má alimentação, durante anos a vítima se alimentava de forma inadequada

A quantidade de corante amarelo solúvel é resultado de sua alimentação, a vítima consumia produtos com essa substância durante anos e repetidas vezes ao dia, logo o Choque Anafilático foi produto de uma má alimentação.

\section{Corante: Amarelo da Tartrazina}

$\checkmark$ Presente em alimentos como: Aperitivos, coberturas, recheios, refrigerantes, xaropes entre outros produtos.

$\checkmark$ Importante saber: Dentro dos corantes azo,o amarelo da tartrazina é o maior responsável por reações alérgicas.

$\checkmark$ Foi constatado que pessoas sensíveis à aspirina apresentam, também, aversão a esse corante.

$\checkmark$ Em Informe Técnico no. 30, de 24 de julho de 2007 da ANVISA, devido estudos realizados no Estados Unidos terem demonstrado casos de reações alérgicas ao corante amarelo tartrazina, foi proposto a inclusão de advertência nos alimentos sobre os efeitos do corante tartrazina em pessoas sensíveis por meio da Consulta Pública no. 68. Porém a inclusão da frase "Contém Corante Amarelo Tartrazina", porém foi descartada por não possuir base científica para a comprovação da intolerância a tartrazina por populações específicas. 


\section{Evidências do caso 02}

01.Paolla era enfermeira.

02.No laudo toxicológico foi apontado níveis extremamente altos de uma toxina de coloração verde, insolúvel.

03.Nas taças examinadas foi encontrado DNA do namorado, de um homem e outra mulher.

04.0 vizinho relatou que a vítima teria tido uma discussão com seu ex namorado.

05.0 ex namorado da vítima é garçom e não estava trabalhando na noite do crime.

06.0 namorado atual da vítima é químico e cozinheiro por esporte.

07.Na noite do crime Paolla deu um jantar para comemorar sua promoção.

08.Na noite do crime o jantar foi feito com a ajuda de todos.

09.A outra mulher presente no dia do crime era Margaret, amiga de Paolla, que também estava concorrendo a uma promoção no hospital. Paolla ganhou a promoção e o jantar foi pra comemorar.

10. Paolla era alérgica a frutos do mar,e alimentos de coloração verde quimicamente processados.

11.0 namorado de Margaret tinha tido um romance com Paolla, porém terminaram e ela começou a namorar com outro.

12.Pergunta BÔNUS

$\checkmark$ Explique o que são pigmentos?

$\checkmark$ Se ACERTAR jogue de novo.

$\checkmark$ Se errar deixe de jogar por DUAS rodadas.

13.Passe sua vez.

14.Indique alguém para ficar uma rodada sem jogar.

15.Investigadores trabalham melhor em grupo, aponte outro investigado para lhe dizer todas as suas informações.

16.Tem momentos na investigação que se tornar impossível chegar à uma conclusão sozinho(a), logo indique alguém para jogar com você até o final do jogo.

$\checkmark$ Os dois jogadores apesar de jogarem em dupla, devem ser tratados como um só, ou seja, terão direito apenas um chute fora ao inicial

$\checkmark$ As evidências de ambos devem ser unidas e subtraídas do valor limite (ou seja, se as evidências totalizarem três ou mais, estes já terão que dizer o seu suspeito final)

$\checkmark$ Se a soma da evidencias totalizarem um valor inferior ao número limite, os investigadores devem conversar e descarta um dos suspeitos escolhidos no início do jogo

17.De exemplo de corantes artificias.

18.Explique a importâncias dos corantes para a indústria. 
19.A pancada não foi a causa da morte, foi causada pela queda possivelmente quando a vítima caiu no chão.

20.Somente no copo da vítima foi encontrado uma substância de coloração verde.

21.Foi encontrado um frasco de um isotônico com a mesma substância que estava no suco intestinal a vítima, nele tinha a digital de Margaret.

\section{Solução do caso 02:}

$\checkmark$ A assassina é Margaret, a vítima possuía alergia há alimentos verde quimicamente processados, o corante verde rápido foi utilizado para causar o óbito da vítima. Margaret pegou um pouco de bebida isotônica e misturou ao vinho da vítima.

$\checkmark \quad 0$ uso desse corante é proibido na união europeia.

$\checkmark$ É um corante de difícil absorção nos intestinos, este pode vim a provocar doenças neurológicas.

$\checkmark$ É potencialmente mutagênico e carcinogênico. 


\section{REFERÊNCIAS}

[1] AGENCIA NACIONAL DE VIGILÂNCIA SANITÁRIA. Resolução da diretoria colegiada- RDC no 17, de 16 de Abril de 2010. Disponível em:< www.anvisa.gov.br/legis> Acessado em: 11 setembro. 2020

[2] BOBBIO, P. A.; BOBBIO, F. O. Química do Processamento de alimentos. São Paulo: Livraria Varela Ltda. 1995. 151 p.

[3] FERREIRA, F.S, Aditivos alimentares e suas reações adversas no consumo infantil. Revista da Universidade Vale do Rio Verde, Três Corações, v. 13, n.1, p.397407, 2015.

[4]

Joint FAO/WHO Expert Committee on Food Additives. WHO Technical Report Series 763, World Health Organization, Geneva 1988

[5] SÁ, Rubeneide F. de; SÁ, Carina S. de Morais; MENEZES, Marília G. de; SIMÕES NETO, José Euzébio; CÂMARA, Maria Suely Costa da. JOGO "QUÍMICA EM AÇÃO": PREPARAÇÃO DE UM MATERIAL DIDÁTICO PARA O ENSINO DE QUÍMICA. In: ANNQ, Não use números Romanos ou letras, use somente números Arábicos., 2015, Pernambuco. Anais [...] . Pernambuco: Nova Eja, 2015. p. 5-14. Disponível em: http://projetoseeduc.cecierj.edu.br/eja/recurso-multimidia-

professor/quimica/novaeja/m1u12/jogo-quimica-em-acao-1300407050.pdf. Acesso em: 20 dez. 2020.

[6] PRADO, M. A; GODOY, H. T. Corantes artificiais em alimentos. Alimentos e Nutrição, v.14, n.2, p. 237-250, 2003 


\section{Jogo 11}

\section{Mestre das palavras}

Dayanne Cipriano Costa da Silva

Maria da Conceição Tavares Cavalcanti Liberato 


\section{INTRODUÇÃO}

Ao se estudar os corantes, podemos observar sua diversidade e inúmeras utilizações, essa classe de compostos orgânicos, cada vez mais, chama atenção tanto no âmbito industrial como no acadêmico. Os corantes e pigmentos vem proporcionado no meio universitário intensas pesquisas voltadas, em especial, no que se refere aos seus efeitos para saúde, esses estudos tem impacto direto na indústria de alimentos. Hoje em dia, a satisfação do consumidor não está apenas relacionada com o sabor, aparência, cheiro e atratividade dos alimentos, mas também com seu impacto na saúde, melhoria de vida, qualidade e longevidade (Giusti \& Wrolstad, 2003; Kammerer et al., 2014; Xi et al.,2007).

Considerando as reivindicações/requisitos, cada vez, mais específicos e direcionais do consumidor, um alto nível e pressão de mercado foi exercido sobre as indústrias de alimentos (Agócs \& Deli, 2011; Carocho et al., 2014). Para se entender a extensão de tal assunto, se faz necessário um estudo detalhado sobre os corantes e suas aplicações, ao se trabalhar o assunto em sala, é essencial mostra ao aluno a presença destes em seu dia a dia. Para fins de melhor compreendimento sobre tal conexão, o jogo MESTRE DAS PALAVRAS, promove o exercício da criatividade e raciocínio logico, onde o discente através de um conhecimento previamente estabelecido sobre a temática aborda tenta formar palavras que tenham relação com a palavra mestre.

Objetivo: Formar o máximo de palavras possíveis que tenham conexões com a palavra mestre.

Número de jogadores: De 2 a 4 participantes.

\section{MATERIAL E MÉTODOS}

O mestre das palavras é um jogo inspirado nas palavras cruzadas, a ideia central do jogo é estimular a capacidade cognitiva do aluno e também, ampliar seu conhecimento sobre os corantes e temas a ele relacionados. A partir dos jogos de regras, os participantes conseguem assimilar informações nas suas estruturas cognitivas, e por meio das situações vivenciadas, podem até mesmo acomodar determinados conceitos (Piaget, 1978). O jogo conta com: um tabuleiro, fichas de letras e as cartas do baralho mestre. A medida em que a partida prossegue os participantes devem através da "palavra mestre" formar palavras associadas a esta, com isso, o jogo tenta traçar uma linha tênue entre os conceitos de sala e o dia a dia do discente afim de que suja, por parte destes, o interesse pelo aprofundamento do conteúdo. 


\section{GUIA DO JOGO}

01. Todos os participantes devem jogar os dados, aquele que tirar MAIOR número será o mestre das palavras.

02. 0 mestre das palavras deve:

- Pegar uma carta do baralho mestre e dizer o tema que as palavras devem seguir.

- Com o anexo 01, este deve montar no tabuleiro, no centro, o tema sorteado.

03. Logo após os participantes, um por vez, terão o tempo de um minuto para montar uma palavra que tenha alguma relação com a palavra do central.

- Não são permitidas palavras iguais.

- O líder da rodada deve pedi para aos participantes que joguem os dados, novamente, para decidir a vez de cada um.

04. A cada rodada, aqueles não conseguirem montar a palavra devem ser desclassificados. 
Anexos

Figura 1:Carta de palavras
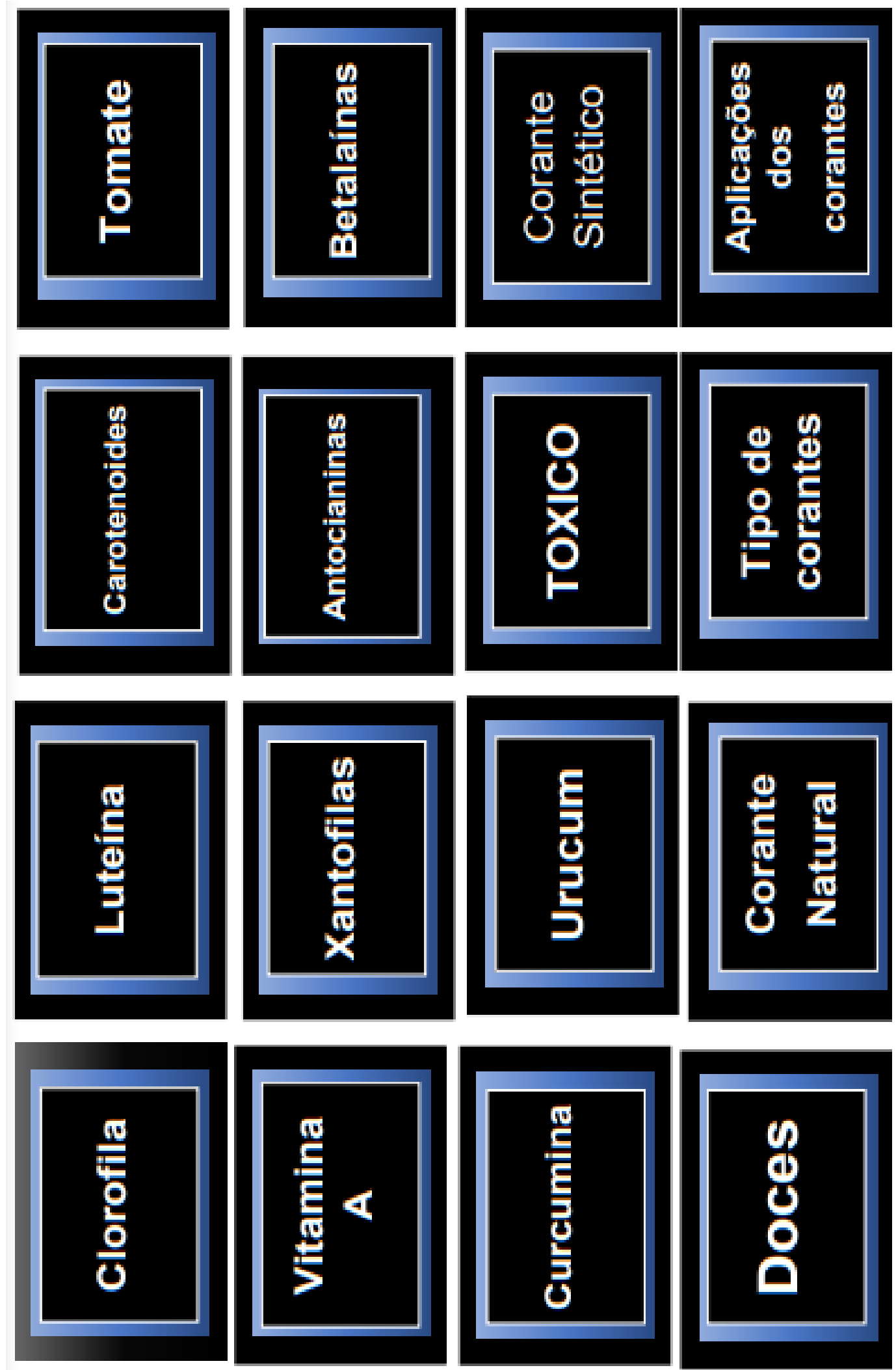





Figura 3:Letras do mestre das palavras

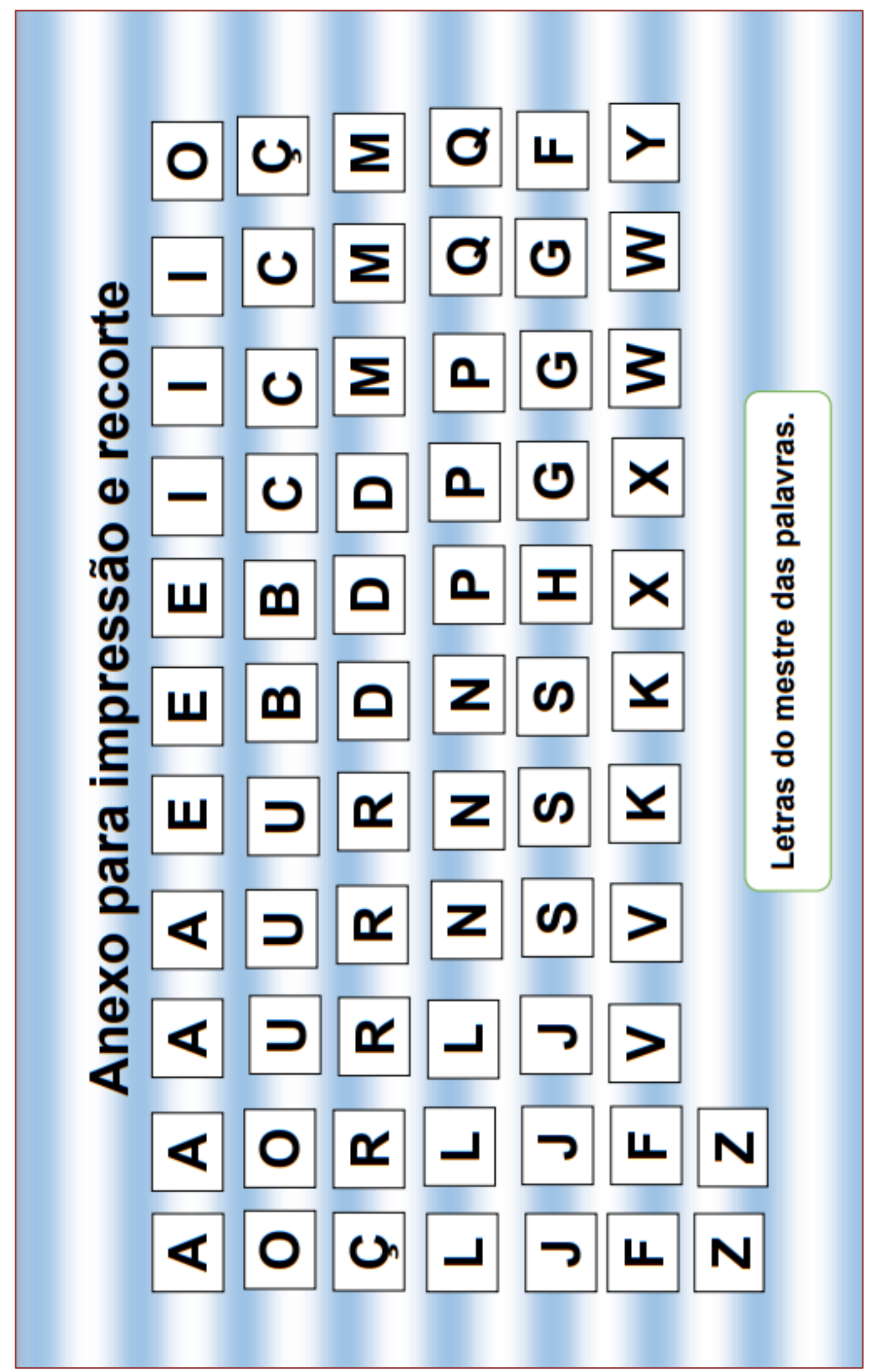


Figura 4: Tabuleiro

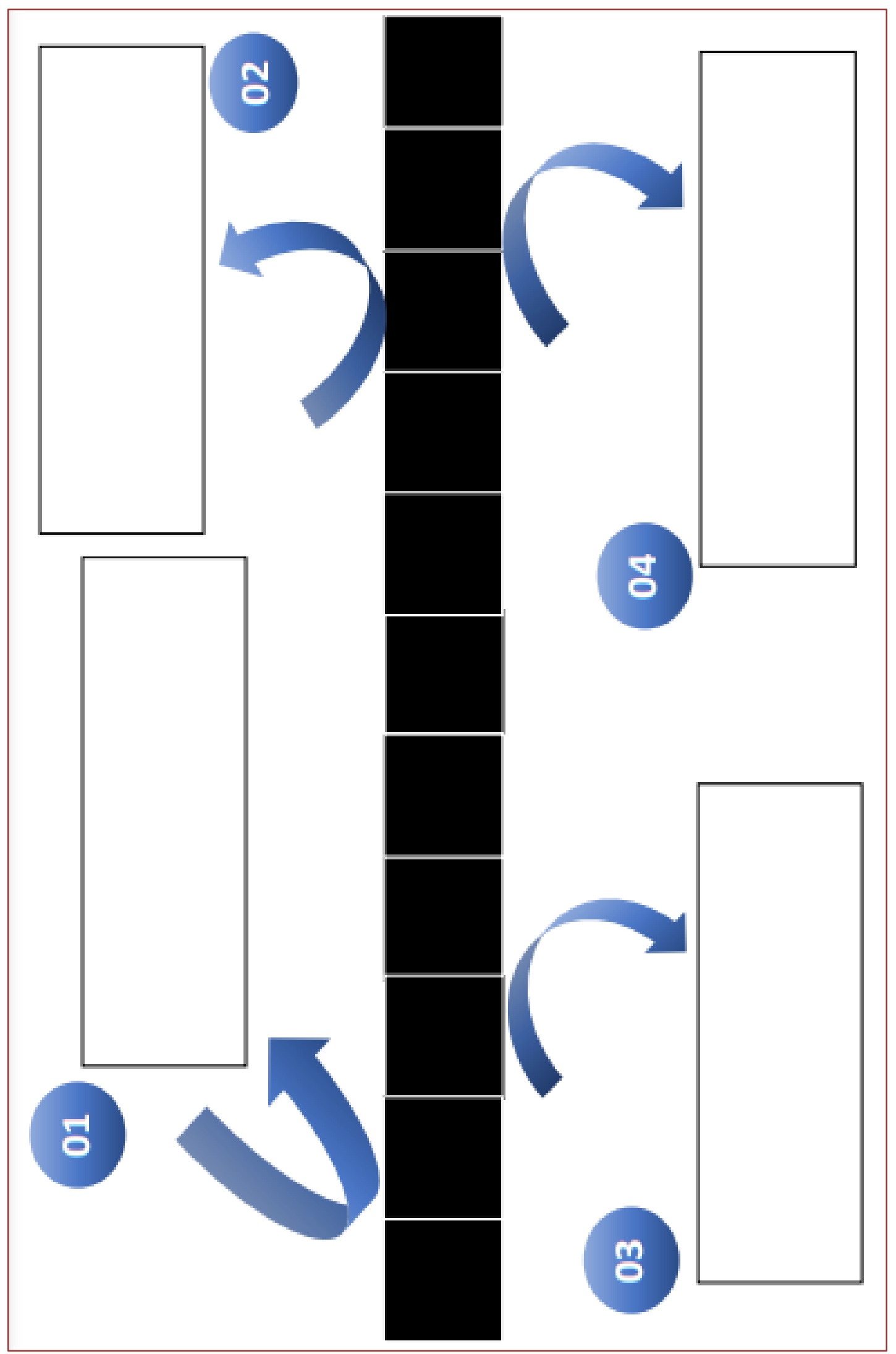




\section{REFERÊNCIAS}

[1] Agócs \& Deli, 2011.Pigmentos em sua comida. Journal of Food Composition and Analysis , 24 (6), 757-759. Disponível em< http://doi.org/10.1016/j.jfca.2011.07.001 $>$ Acesso em 19 de ago de 2020

[2] Carocho,M,Barreiro,MF,Morales,P.,\&Ferreira,ICFR(2014). Adicionando moléculas para alimentos, prós e contras: uma revisão sobre alimentos sintéticos e naturais aditivos. Comprehensive Reviews in Food Science and Food Safety , 13 (4), 377-399. disponível em <.http://doi.org/10.1111/1541-4337.12065> Acesso em 18 de ago de 2020

[3] Giusti,MM e Wrolstad,RE(2003).Antocianinas aciladas de fontes comestíveis e suas aplicações em sistemas alimentares. Biochemical Engineering Journal , 14 (3), 217-225.disponivel em:< http://doi.org/10.1016/S1369-703X(02)00221-8>. Acesso em 23 de ago de 2020

[4] Kammerer,DR.Kammerer,J.,Valet,R.,\&Carle,R. Recuperação de polifenóis de subprodutos do processamento de alimentos vegetais e aplicação como valiosos ingredientes alimentares. Food Research International , 65 , 2-12. Disponível em :<http://doi.org/10.1016/j.foodres.2014.06.012>. Acesso em 23 de ago de 2020

[5] NETTO, R. C. M. Dossiê corantes. FOOD INGREDIENTS BRASIL, n. 9, 2009. Disponível em: . Acesso em: 13 de.sept.2020 .

[6] Piaget, J. (1978). A formação do símbolo na criança: imitação, jogo e sonho, imagem e representação. 3. ed. Rio de Janeiro: Zahar Editores.

[7] POLONI, R.; LUCA, M. Corantes naturais frentes às tendências mundiais. Periódico Tchê Química, v. 4, n. 7, p. 33-40, Porto Alegre, 2007. Disponível em:<http://www.deboni.he.com.br/tq/revista/revista7.htm> Acesso em: 13 de.sept.2020 .

[8] SOUZA, R. M. CORANTES NATURAIS ALIMENTÍCIOS E SEUS BENEFÍCIOS À SAÚDE. 2012. Monografia (Graduação Farmácia), Centro Universitário Estadual da Zona Oeste, Rio de Janeiro, 2012. Orientador: Professor Marco Antônio Mota e Professora Sabrina da Silva Dias.

[9] VELOSO, L. A. Corantes e Pigmentos - Dossiê Técnico. Serviço Brasileiro de Respostas Técnicas. Instituto de Tecnologia do Paraná, 2012.

[10] Xi,L., Qian, Z., Xu, G., Zheng, S., Sun, S., Wen, N.,... Zhang, Y. (2007). Benéfico impacto da crocetina, um carotenóide do açafrão, na sensibilidade à insulina na frutose ratos alimentados. The Journal of Nutritional Biochemistry,18(1)64-72. http://doi.org/10.1016/j.jnutbio.2006.03.010 Acesso em: 13 de.sept.2020 


\section{Jogo 12}

\section{Quem sou eu?}

\section{Dayanne Cipriano Costa da Silva}

Maria da Conceição Tavares Cavalcanti Liberato 


\section{INTRODUÇÃO}

A força expressiva da cor, quando usada em uma composição, está subordinada a uma série de regras, que podem alterar, aumentar ou moderar seu poder (FARINA, 1986). De fato, as cores tem um papel essencial em nossa vida, sendo que, sua ausência ou exerço se torna um fator determinante na escolha de um alimento. A relação entre o homem e a cor é altamente explorada pela indústria, uma vez que, alimentos coloridos aguçam os sentidos tornando-se mais desejáveis, no entanto, as polêmicas em volta da utilização de certos corantes em alimentos, cresce à medida em que as indústrias alimentícias prosperam. Tais questões são amplamente estudas em sala de aula, sendo que, ao aborda tal temática em sala (Corantes e aspectos a ele relacionados), se faz imprescindível a utilização do lúdico/educativo.

Para Kishimoto (1996), a lúdica está relacionada ao caráter da diversão e prazer que um jogo propicia. A educativa se refere à apreensão de conhecimentos, habilidade e saberes. Assim, a união entre esses dois pilares, em um jogo, favorece ao aluno o desenvolvimento de um aprendizado crítico, já para docente, o jogo mostra-se como meio de fixação do conteúdo e avaliação da aprendizagem.

Objetivo: Descobrir através das pistas: o corante, pigmento ou grupo de corantes misterioso.

Número de jogadores: De 2 a 4 pessoas.

\section{MATERIAL E MÉTODOS}

Segundo Brougére, as atividades lúdicas proporcionam ao indivíduo uma oportunidade a mais de abastecer informações, baseando-se em simulações e fantasias que ele executa. Afim de se trabalhar didaticamente o assunto: "corantes, tipos, aplicações e afins "foi criado o jogo "QUEM SOU EU?", sendo esse inspirado no PERFIL 6 (jogo da GROW, empresa de entretenimento). Este tem como proposta despertar a curiosidade dos alunos e também promover uma rápida avalição de aprendizagem do conteúdo.

\section{ESTRUTURA DO JOGO}

O jogo conta com 4 pinos (amarelo, verde, vermelho e azul), 16 cartas de dicas, e um tabuleiro.

Observação: As cartas de dicas estão divididas em: oito cartas sobre corantes naturais e/ou seus grupos e oito cartas sobre corantes sintéticos.

\section{Guia do jogo:}

1.Cada participante deve escolher uma cor de pino, em seguida posiciona-lo no local de início.

Observação: Os participantes devem escolher entre si a ordem de sequência da partida. 


\section{ATENÇ̃̃O PARTICIPANTES}

2. Quando for sua vez, puxe a carta do baralho e entregue a um dos participantes da mesa, este será responsável por ler as dicas.

3. A soma da pontuação de cada carta são 3 pontos, a medida em que você necessita de mais informações o valor da ficha diminui, ou seja:

3.1 Se você usou até 3 dicas, sua pontuação é 3, logo ande três casas.

3.2 Se você usou as 5 dicas, sua pontuação é 1 , logo você só pode andar 1 casa.

3.3 Em caso de erro, mesmo após as cinco dicas, não a pontuação. 


\section{ANEXOS}

Figura 1: Tabuleiro (Fonte autores)

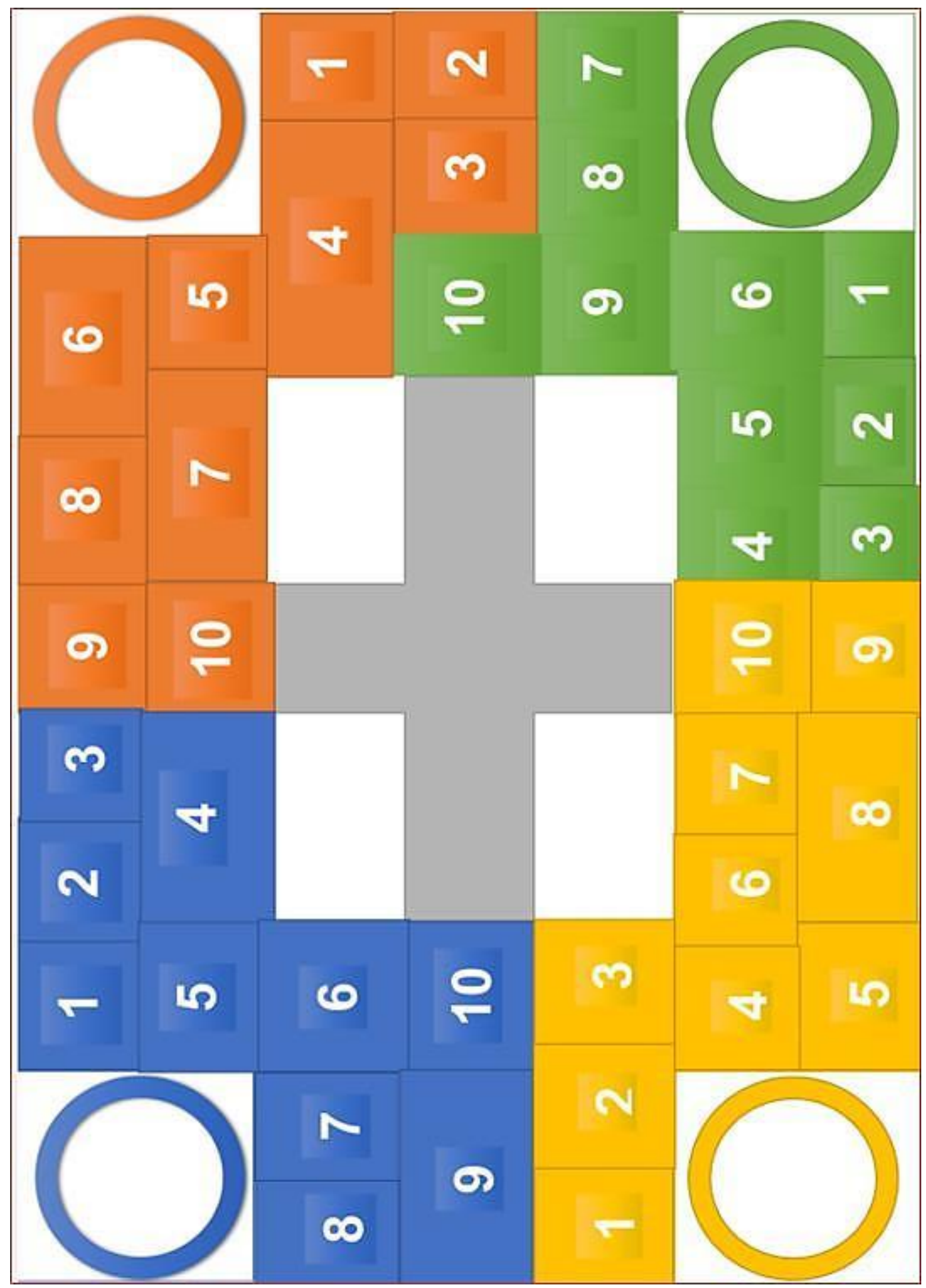


Figura2: Pinos (Fonte autores)
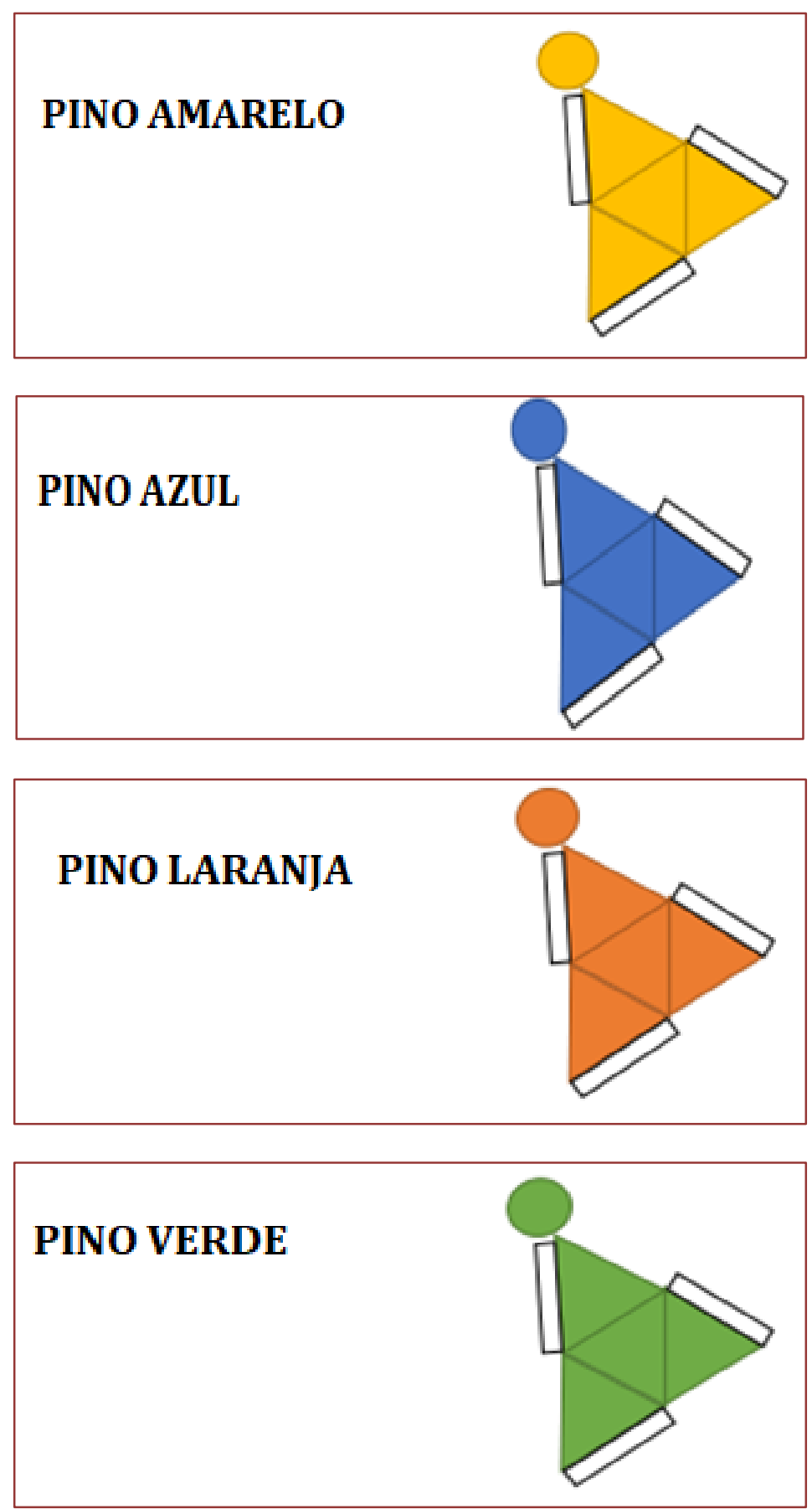


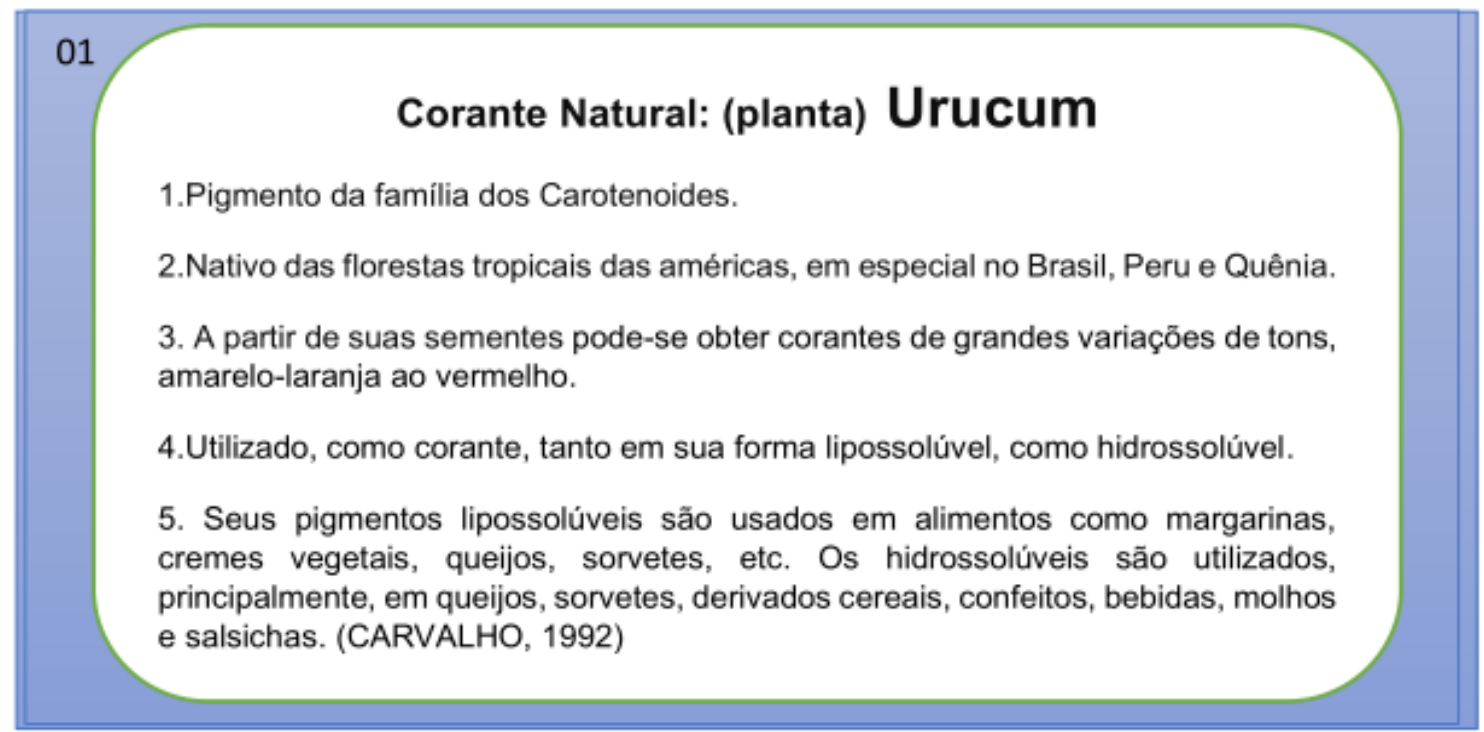

02

\section{Grupo de pigmentos: Carotenoides}

1. Pertencente a classe dos compostos isopropenoides.

2.Responsavel pela coloração vermelha, laranja e amarela em frutas e vegetais em flores, fruto e algumas raizes.

3. Produzidos por bactérias, fungos, leveduras e plantas.

4. Diversos composto de grupo, possuem atividade pró vitamínica $\mathrm{A}$ e, consequentemente, agregam ao alimento um importante valor nutricional, bem como estético.

5. utilizados como corantes na indústria de laticínios, saladas, maioneses e bebidas.

03

\section{Grupo de pigmentos :Xantofilas}

1.Pertencente a classe dos compostos isopropenoides, sendo também chamado de terpenoides

2. Bastante utilizada para intensificar a cor amarela das gemas de ovos.

3.Relaciondos a prevenção de câncer de próstata e fígado.

4.Neste grupo são englobados a luteina e zeaxantina.

5.Produtos alimentícios processados como molhos, sopas em pó de preparo instantâneo, salsicha e salame, contém o corante extraído do pimentão vermelho, este por sua vez, pertencente a essa classe de compostos. 


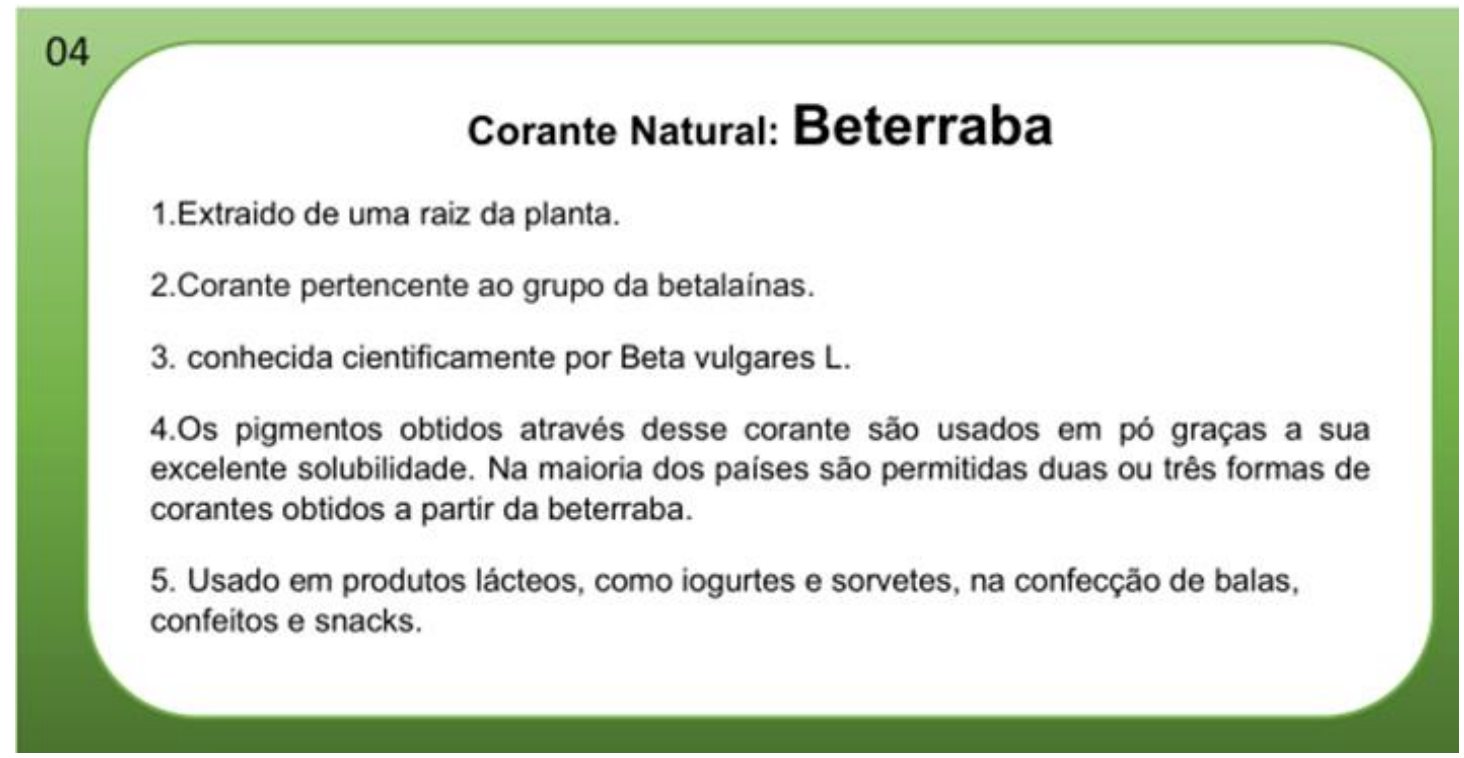

05

\section{Grupo de pigmentos: Betalaínas}

1.Compostos $\mathrm{N}$-heterociclico

2.. São um grupo de pigmentos amarelos, vermelhos e púrpura

3.Essa classe de corante possui, dois tipos de pigmentos: betacianinas (vermelhas) e as betaxantinas (amarelas)

4. 0 ácido ascórbico e 0 ácido citrico podem ser adicionados aos processos, para controlar melhor a sua oxidação (ARAU JO, 1995) permitindo assim que eles sejam adicionados a sorvetes, produtos congelados, sobremesas à base de frutas, bombons, pudins (FREUND e WASHAM, 1988).

5. Estável em pH entre 4,0 e 7,0

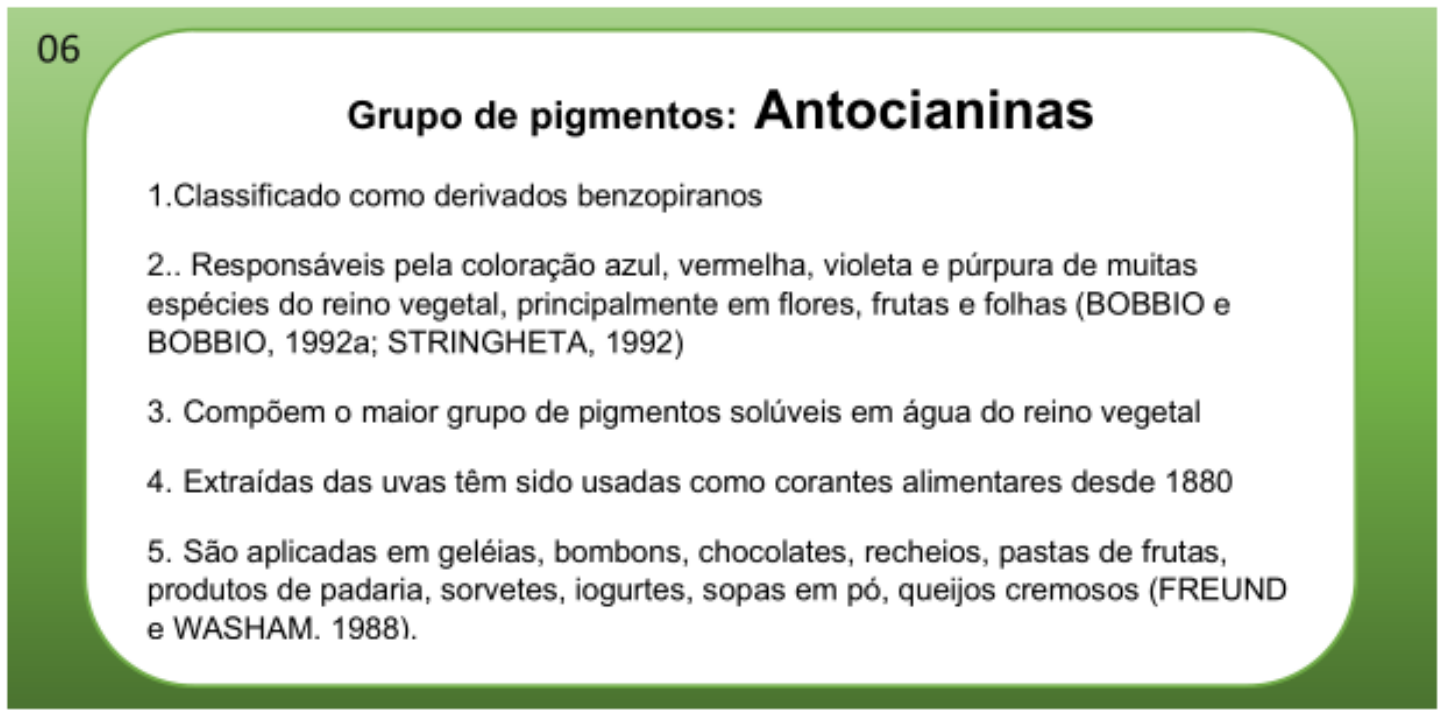



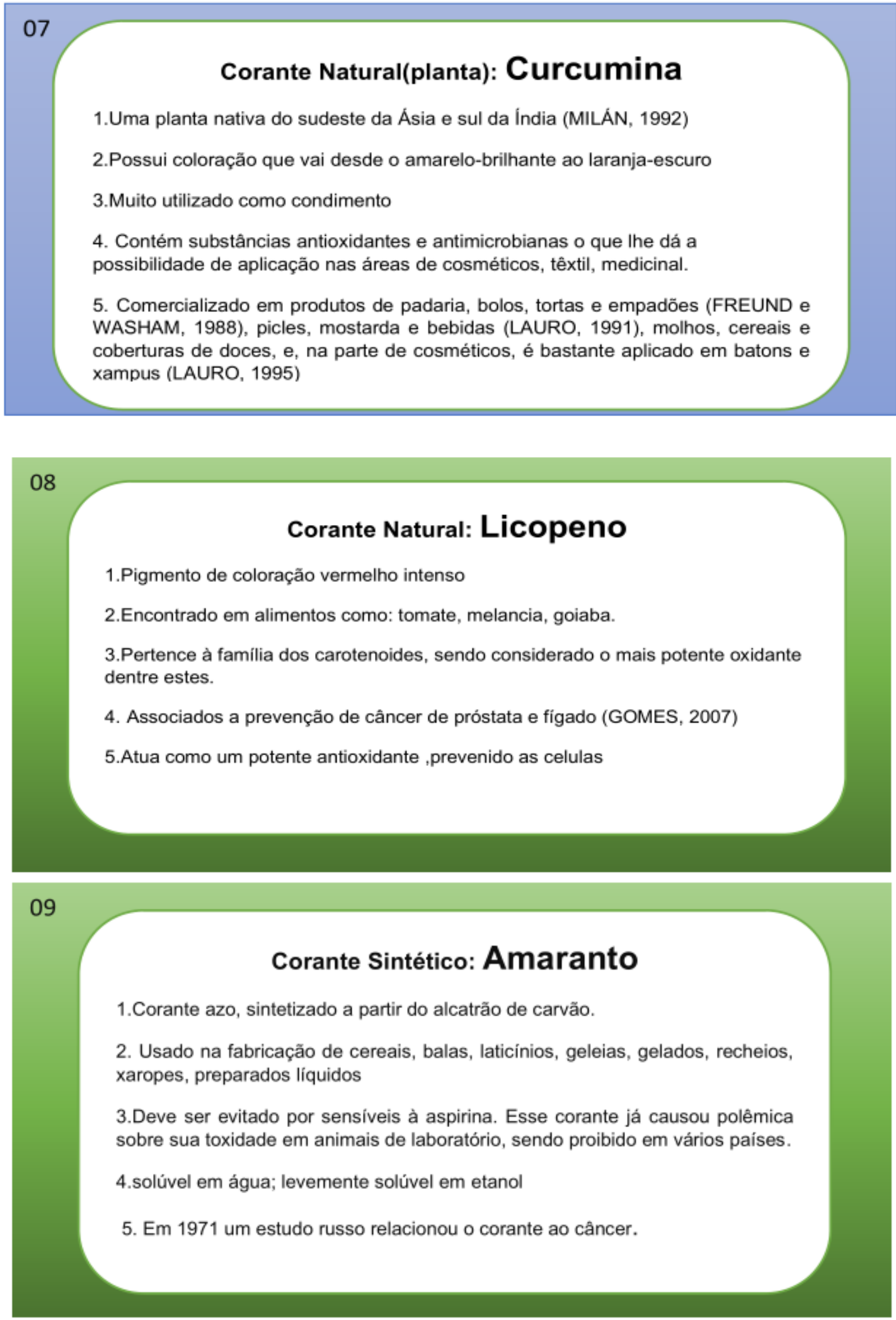


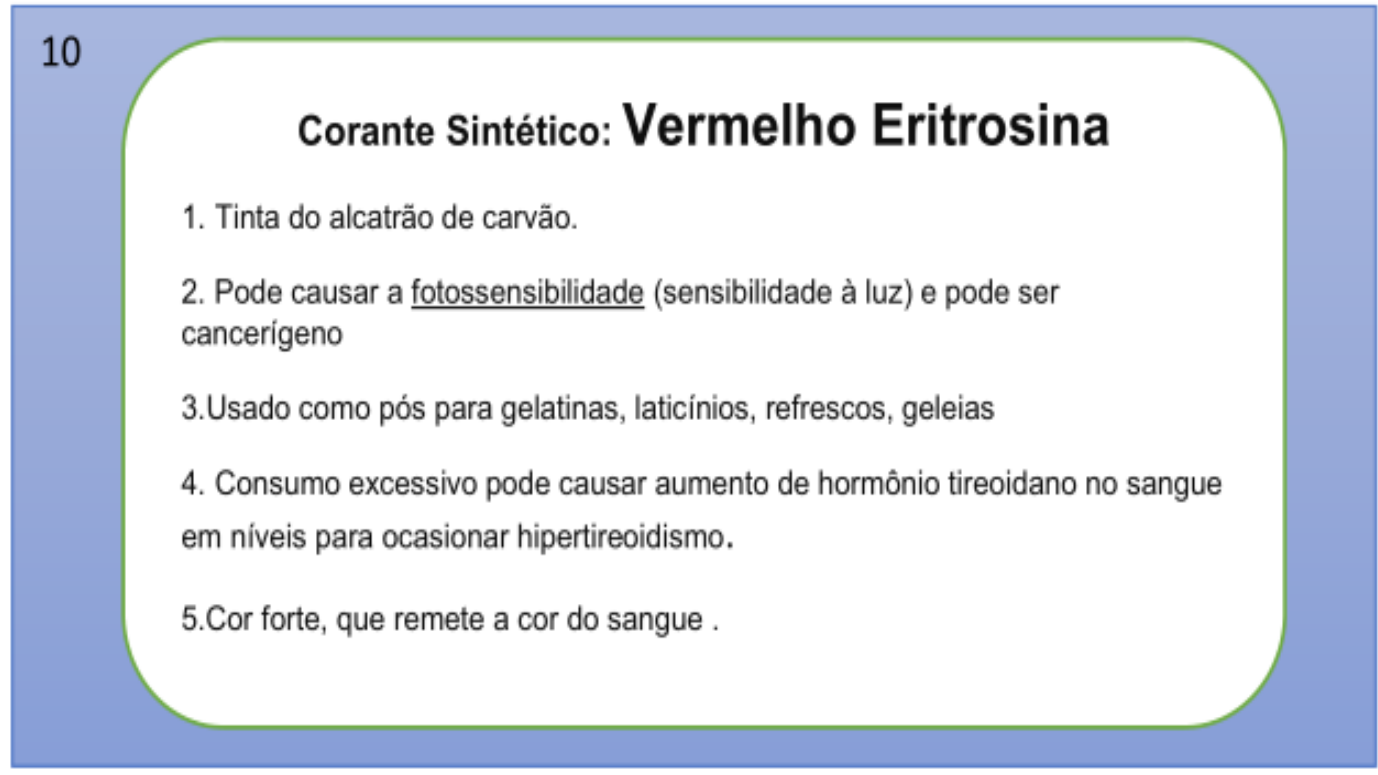

\section{1 \\ Corante Sintético: Indigotina (azul escuro)}

1.Produzido a partir da tinta do alcatrão de carvão

2. Insolúvel em água ou em solventes polares.

3. Pode causar náuseas, vômitos, hipertensão e ocasionalmente alergia, com prurido e problemas respiratórios.

4. Pode ser usado em combinações para se conseguir outras cores como o rosa, 0 anil e o roxo

5.Útil quando se deseja associar ao sabor de uva, groselha e ameixa.

12

\section{Corante Sintético: Vermelho Ponceau 4R}

1. Sintetizado a partir da tinta do alcatrão de carvão.

2.Aplicado em :Frutas em caldas, laticínios, xaropes de bebidas, balas, cereais, refrescos e refrigerantes, sobremesas.

3. Corante considerado ácido, pertencente a classe dos azoicos.

4. Deve ser evitado por pessoas sensíveis à aspirina e asmáticos. Esse pode causar anemia e aumento da incidência de glomerulonefrite (doença renal).

5. foi proibido nos Estados Unidos e teve seu uso restrito em alguns países da União Européia. 


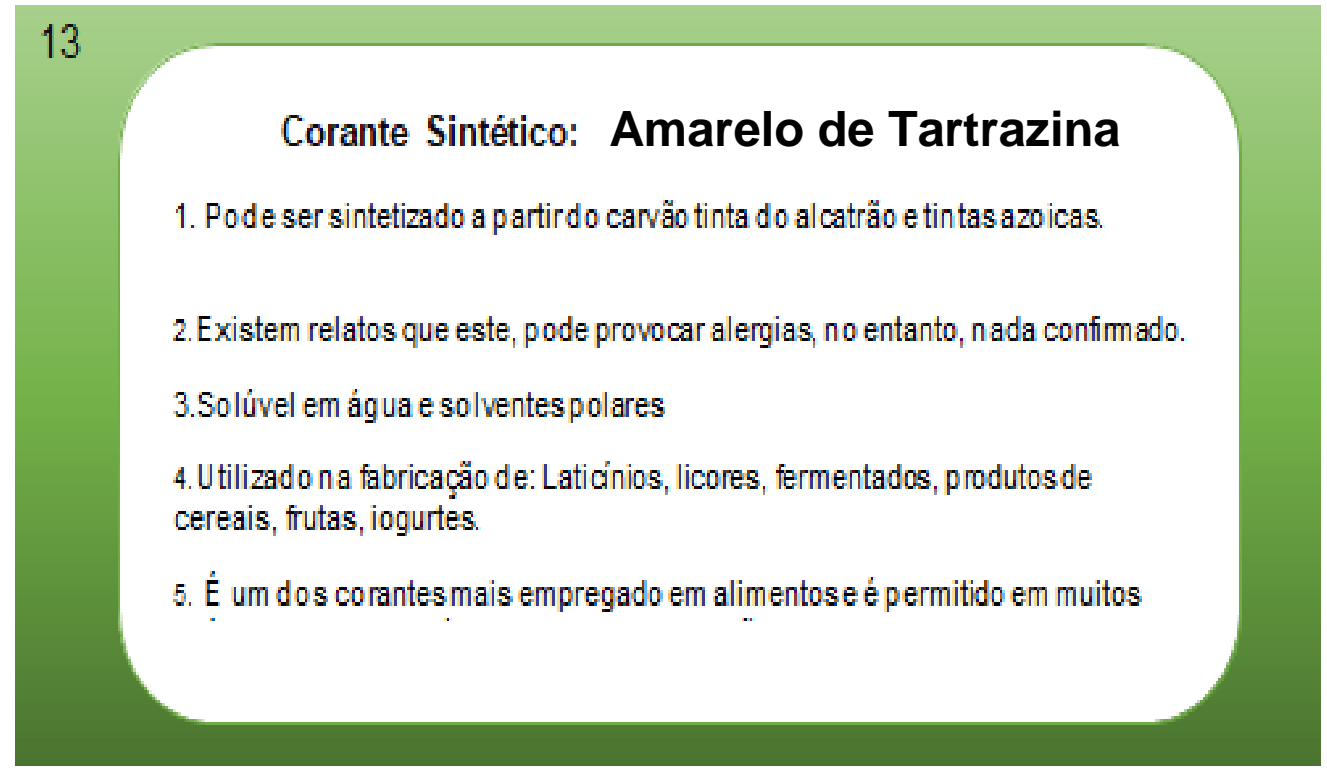

14

\section{Corante Sintético: Amarelo Crepúsculo}

1. Estados Unidos, Japão e paises da UE permitem o emprego desse corante em alimentos

2.Sintetizado a partir da tinta do alcatrão de carvão e tintas azóicas

3.Usado na fabricação de: cereais, balas, caramelos, coberturas, xaropes, laticinios, gomas de mascar.

4.Em algumas pessoas pode causar alergia, produzindo urticária, angioedema e problemas gástricos

5. Possui boa estabilidade na presença de luz, calor e ácido.

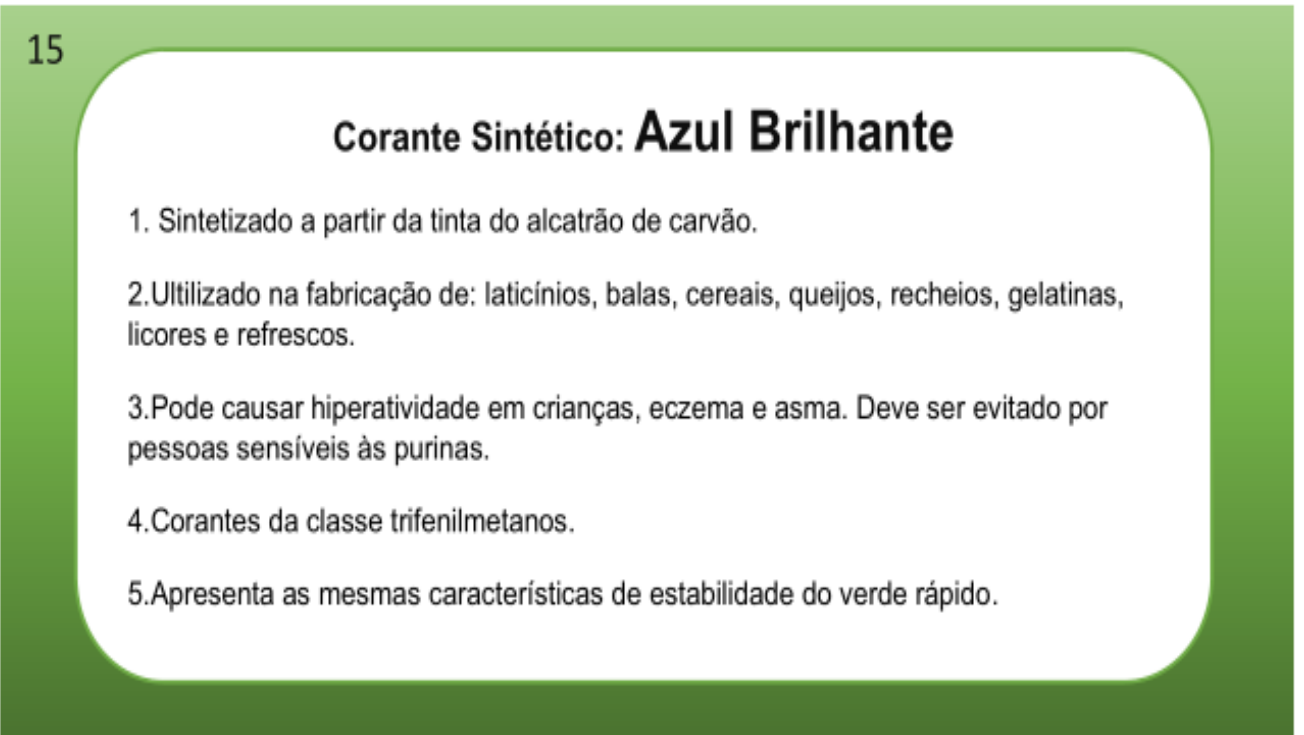




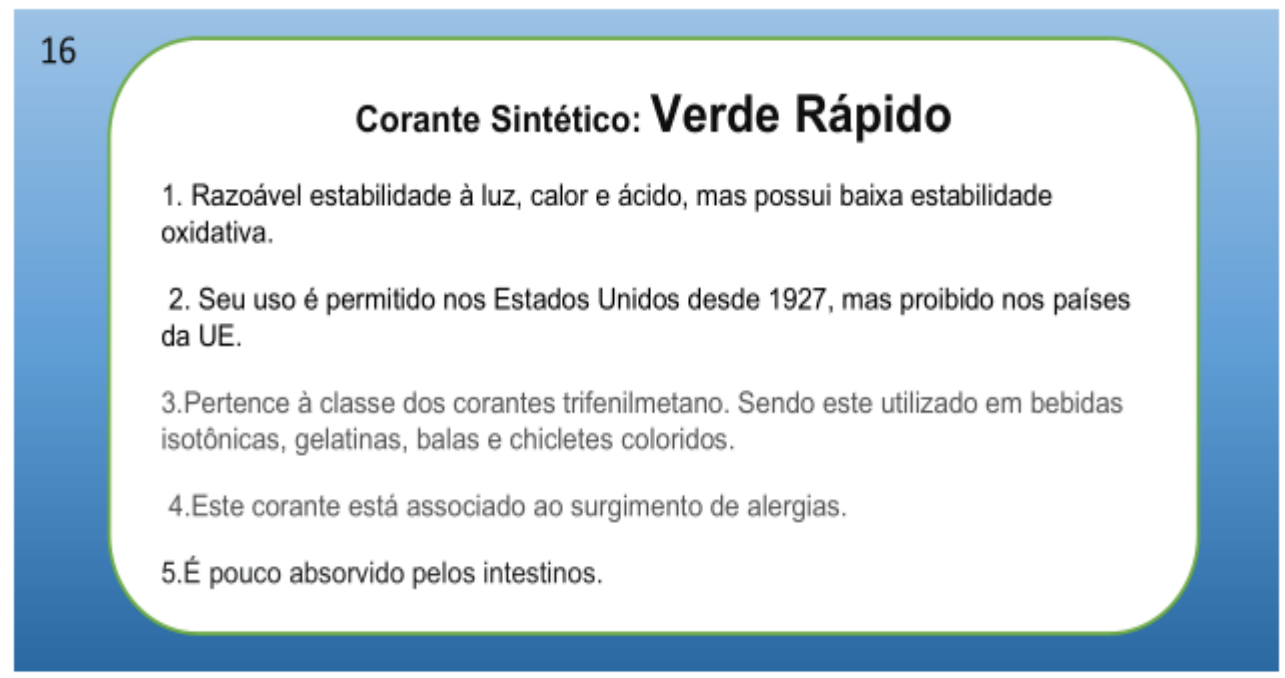

\section{REFERÊNCIAS}

[1] FARINA, Modesto. Psicodinâmica das cores em comunicação. 2ł. ed. São Paulo: Edgard Blücher, 1986.

[2] KISHIMOTO, T. M. Jogo, brinquedo, brincadeira e a educação. São Paulo: Cortez, 1996.

[3] NETTO, R. C. M. Dossiê corantes. FOOD INGREDIENTS BRASIL, n. 9, 2009. Disponível em: https://revista-fi.com.br/upload_arquivos/201606/2016060213572001465326315.pdf Acesso em: 13 de.sept.2020.

[4] POLONI, R.; LUCA, M. Corantes naturais frentes às tendências mundiais. Periódico Tchê Química, v. 4, n. 7, p. 33-40, Porto Alegre, 2007. Disponível em:<http://www.deboni.he.com.br/tq/revista/revista7.htm> Acesso em: 13 de.sept.2020 .

\section{[5] SOUZA, R. M. CORANTES NATURAIS ALIMENTÍCIOS E SEUS BENEFÍCIOS À}

SAÚDE. 2012. Monografia (Graduação Farmácia), Centro Universitário Estadual da Zona Oeste, Rio de Janeiro, 2012. Orientador: Professor Marco Antônio Mota e Professora Sabrina da Silva Dias.

[6] VELOSO, L. A. Corantes e Pigmentos - Dossiê Técnico. Serviço Brasileiro de Respostas Técnicas. Instituto de Tecnologia do Paraná, 2012. 


\section{Jogo 13}

\section{Jogo do impostor 1 (Pigmentos e Corantes)}

\section{Letícia de Araújo Rodrigues}

Pedro Filipe Lemos Vieira

Maria da Conceição Tavares Cavalcanti Liberato 


\section{INTRODUÇÃO}

A metodologia utilizada no ensino de química pode ajudar no desenvolvimento do aluno, diante disso é importante a criação de materiais didáticos para auxiliar cada vez mais o processo de ensino aprendizagem evitando o desânimo e as possíveis desistências nas disciplinas. Na sala de aula o educador utiliza a criatividade para estimular os alunos a participarem da aula. Os jogos didáticos entram como um recurso pedagógico nas aulas de química, a utilização dos jogos promove a convivência e estabelece uma relação interpessoal.

\section{Objetivo}

Ensinar de maneira interativa o conteúdo de pigmentos e corantes através de um jogo.

\section{Objetivos Específico}

- Aguçar o interesse do estudo da química dos corantes e pigmentos;

- Atrair a atenção dos alunos para o ensino de corantes e pigmentos;

- Aplicação de jogos didáticos e materiais;

- Expor tais materiais, em especial aos alunos da disciplina de química dos alimentos.

\section{MATERIAL E MÉTODOS}

\section{Público Alvo: Alunos do ensino médio}

\section{Regras:}

1. Será explanado o conteúdo de pigmentos e corantes para a turma de alunos do ensino médio;

2. Após a aplicação, ocorrerá uma divisão em grupos de 5 para melhor discussão entre os alunos;

3. Após a divisão será escolhida aleatoriamente uma carta para cada grupo que tem 5 descrições de pigmentos e corantes escolhidos, sendo que uma descrição é falsa;

4. Os alunos devem identificar a descrição falsa e se acertar passam adiante na atividade;

5. Os grupos que errarem são eliminados, fazendo com que a cada rodada sobrem apenas 1 grupo no final, que será o grupo vencedor.

\section{As cartas seguem esse modelo:}

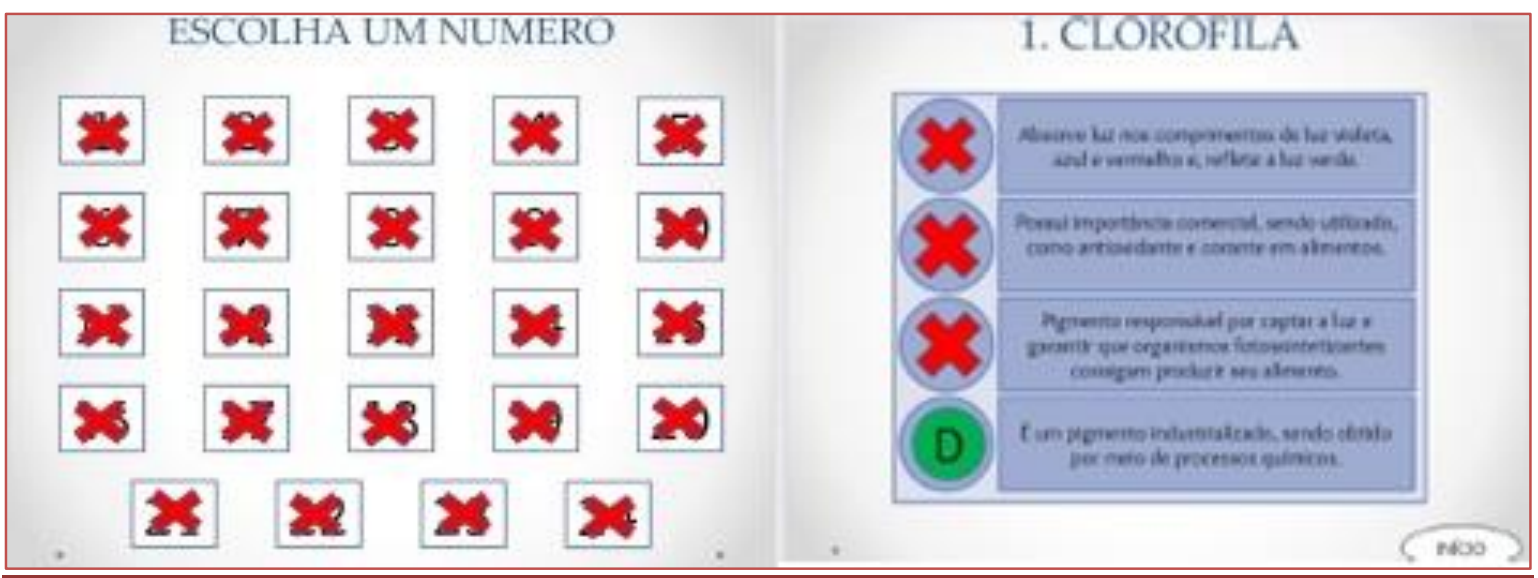




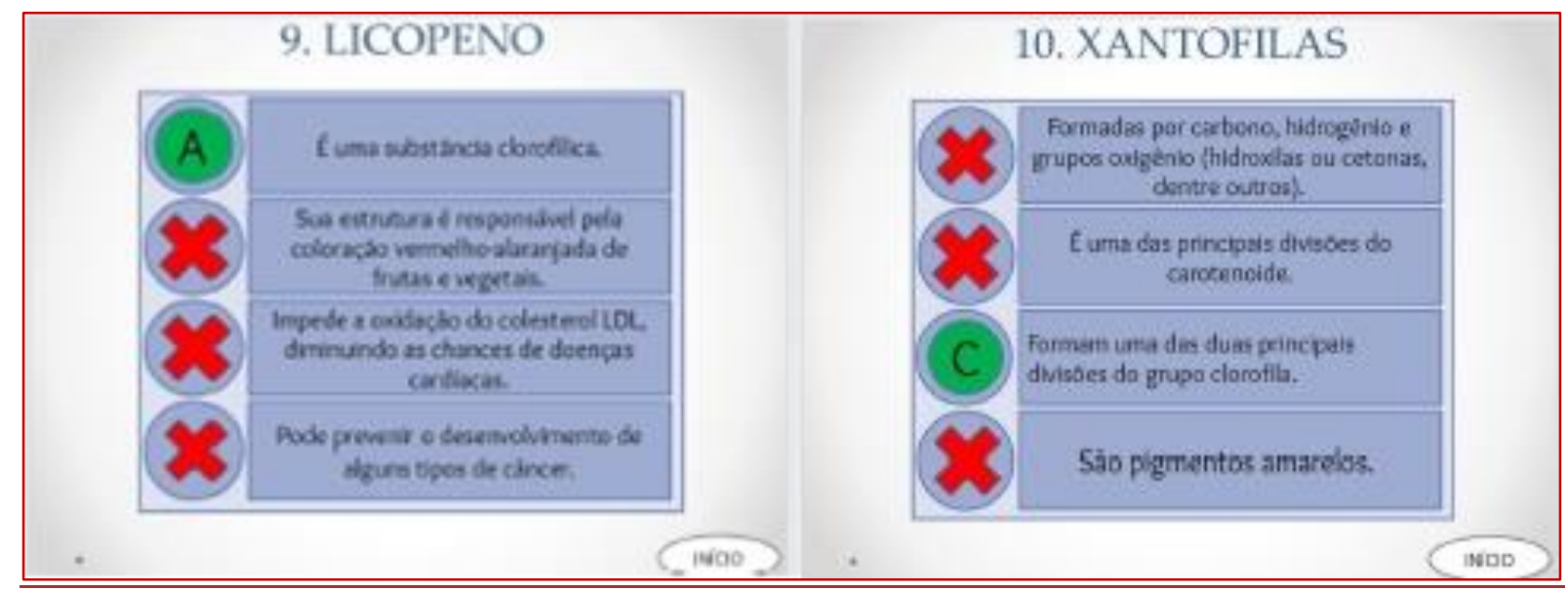

\section{Considerações finais:}

A confecção e aplicação do jogo visa um aumento da eficiência no auxílio do ensino da química em especial no conteúdo de corantes e pigmentos com enfoque de mostrar como os jogos podem facilitar a compreensão da química dos alimentos. Espera-se que os alunos se envolvam no processo de aprendizagem do conteúdo e que os alunos e os professores possam proporcionar esse tipo de contato, mostrando que o aprendizado pode vir de diversas formas.

Segue a lista de características utilizadas no jogo:

(O jogo está disponível em formato de slide interativo) Legenda:
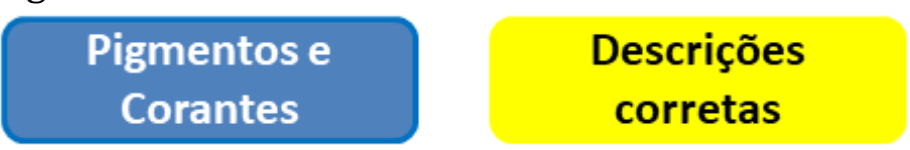

\section{Descrição Falsa}

Pigmentos e Corantes / descrições:

1ㅇ Clorofila:

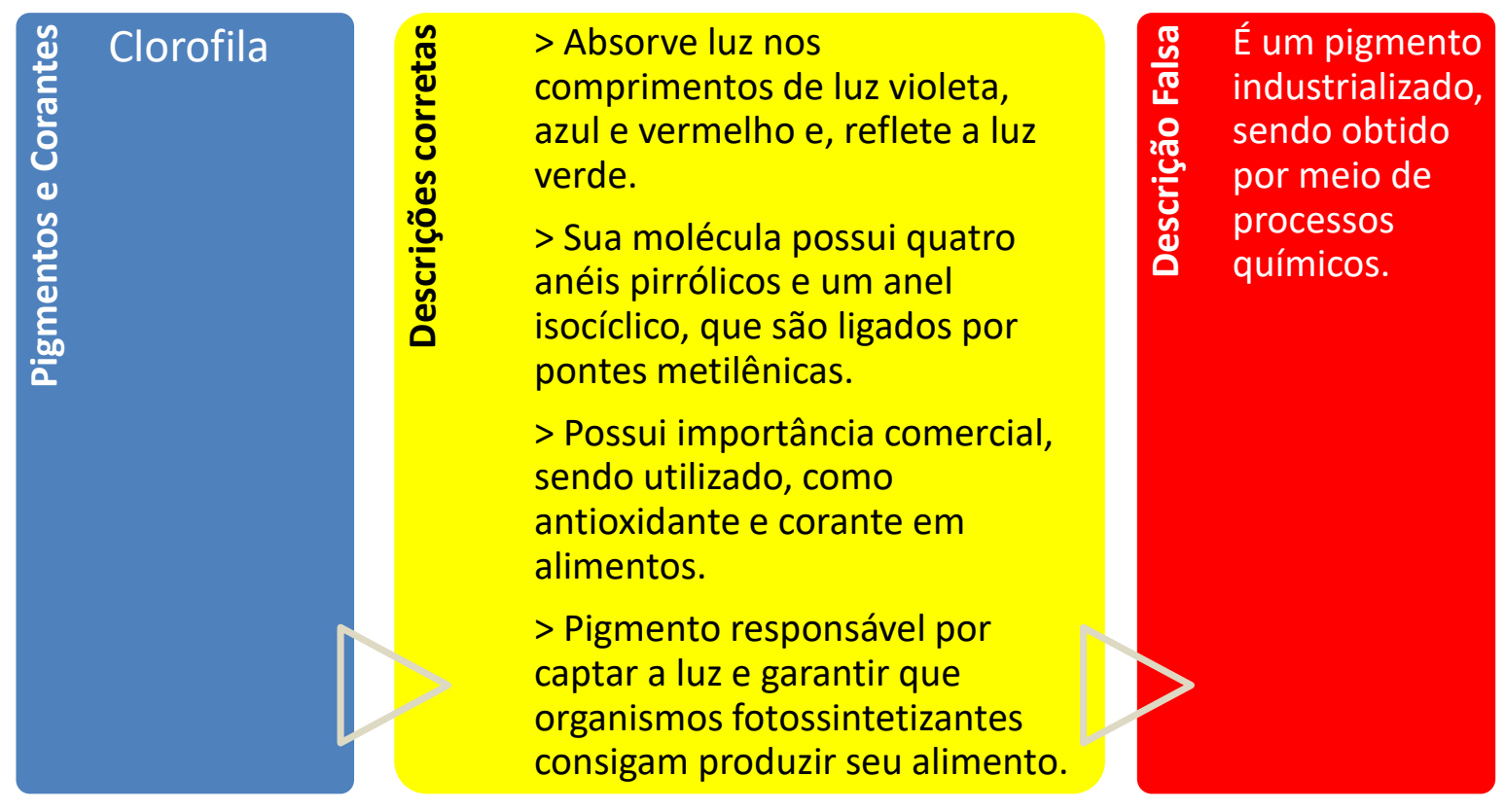


2ํㅡㄹ Bilirrubina:

$\begin{array}{lll}\text { Pilirrubina: } & \begin{array}{l}\text { Pigmento amarelado é } \\ \text { produzido pela quebra do grupo } \\ \text { prostético heme presente nas }\end{array} \\ & \begin{array}{l}\text { células sanguíneas onde a } \\ \text { hemoglobina contida nas células é }\end{array} \\ & \begin{array}{l}\text { > Responsável pelo transporte da } \\ \text { albumina pelas células. } \\ \text { > É o pigmento predominante da } \\ \text { bile. }\end{array}\end{array}$

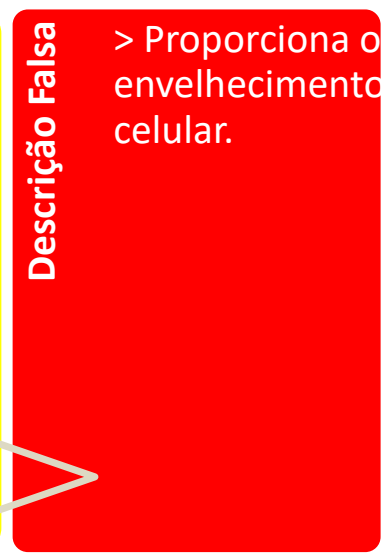

3ํ Hemocianina:
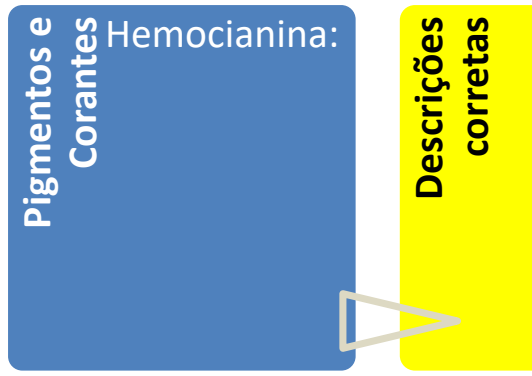

$>$ Pigmento do sangue de muitos moluscos e artrópodes.

> É uma proteína que contém cobre.

> Serve para o transporte de oxigênio.

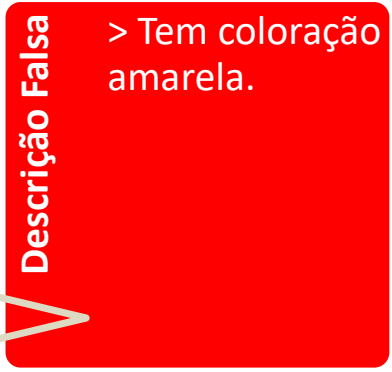

$4^{\circ}$ Hemoglobina:

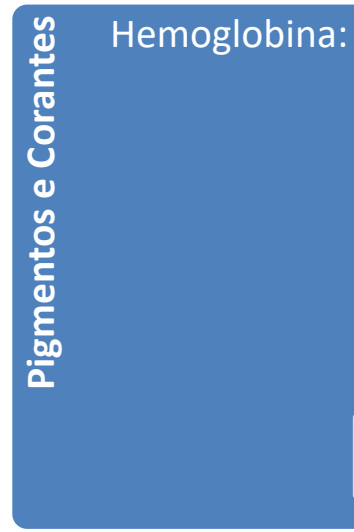

$>$ É uma proteína globular que apresenta estrutura quaternária, sendo formada por quatro subunidades.

$>$ É o pigmento respiratório de quase todos os vertebrados.

$>$ É uma proteína encontrada no sangue dos vertebrados e é responsável pela cor vermelha típica do sangue.

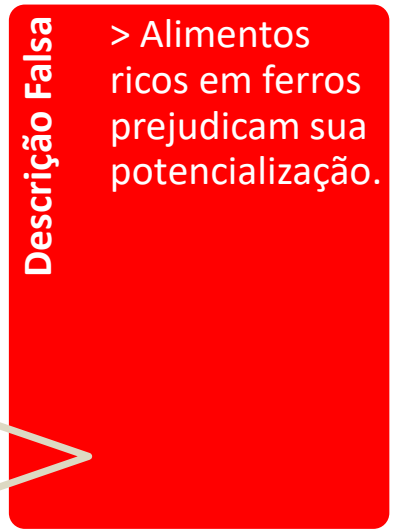

$5^{\circ}$ Luciferina:

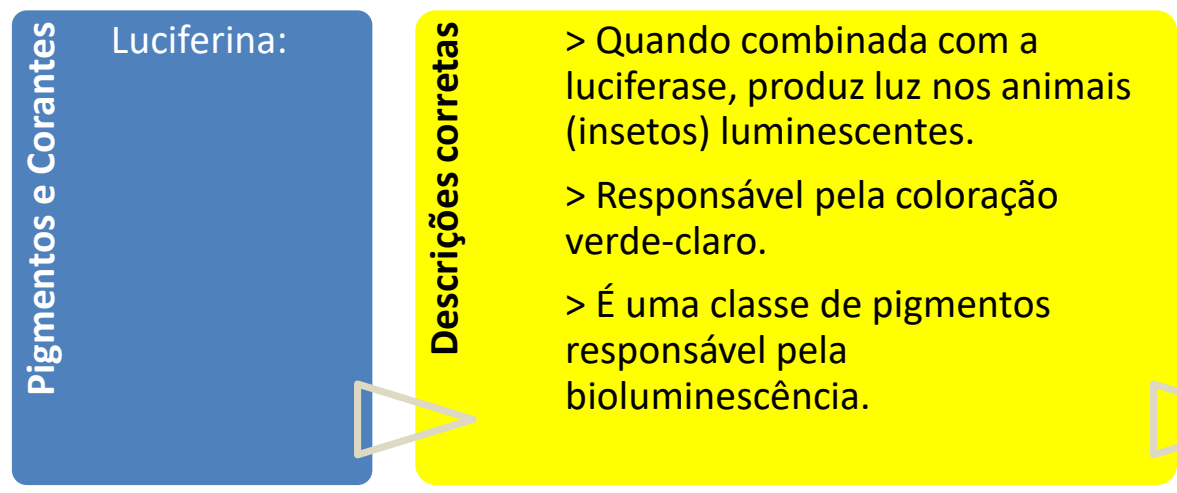

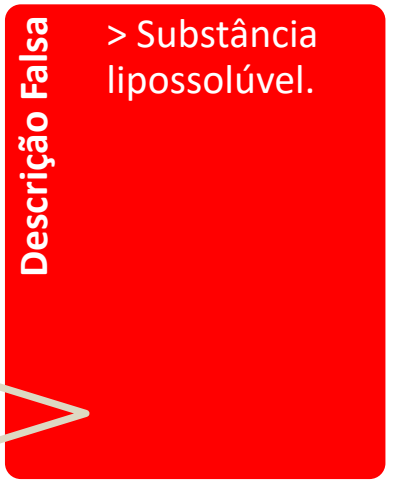


60 Carotenoides:

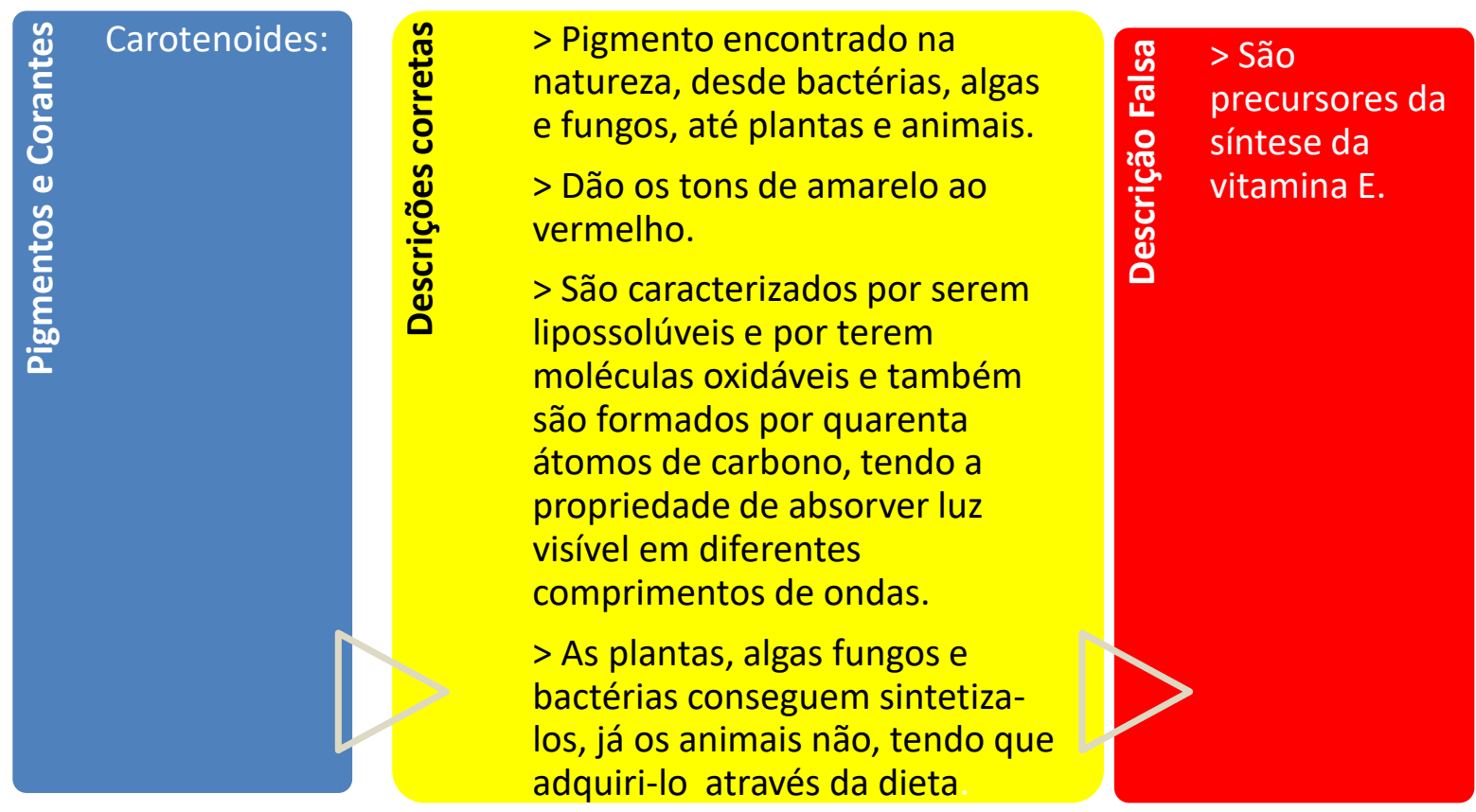

7ํㅡㄹianinas:

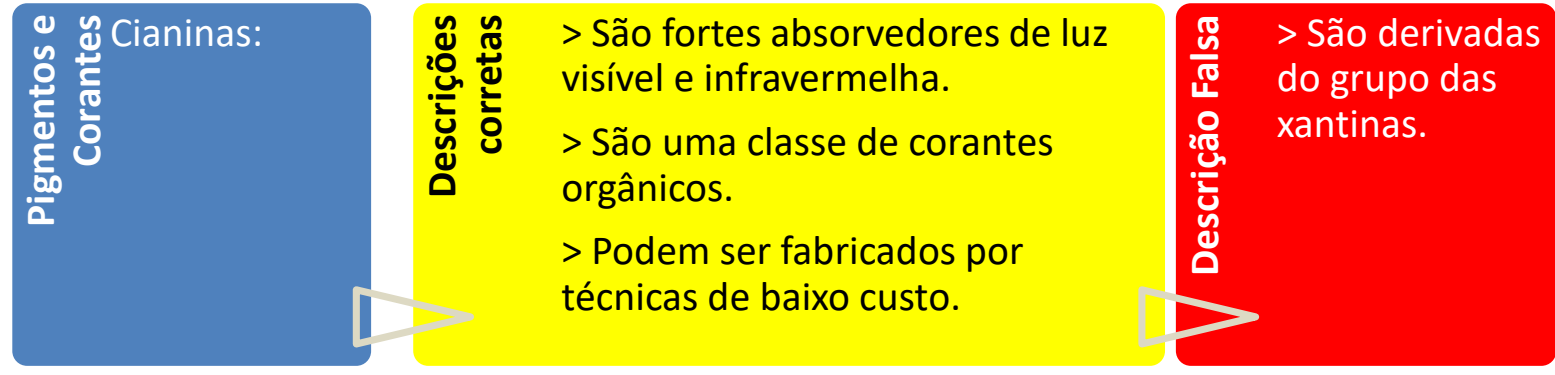

\section{8o Antocianina:}

$\begin{array}{lll}\text { Antocianina: } & \text { Nas flores e frutas a coloração } \\ \text { deste pigmento pode ajudar } & \text { como um fator adicional na } \\ \text { polinização, ajudando no ciclo } & \text { reprodutivo. }\end{array}$

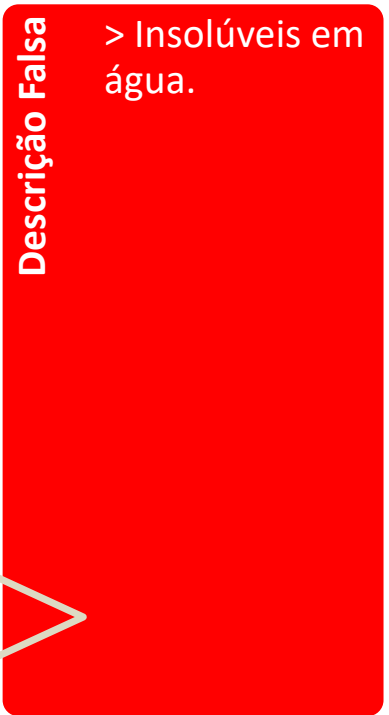


9o Licopeno:

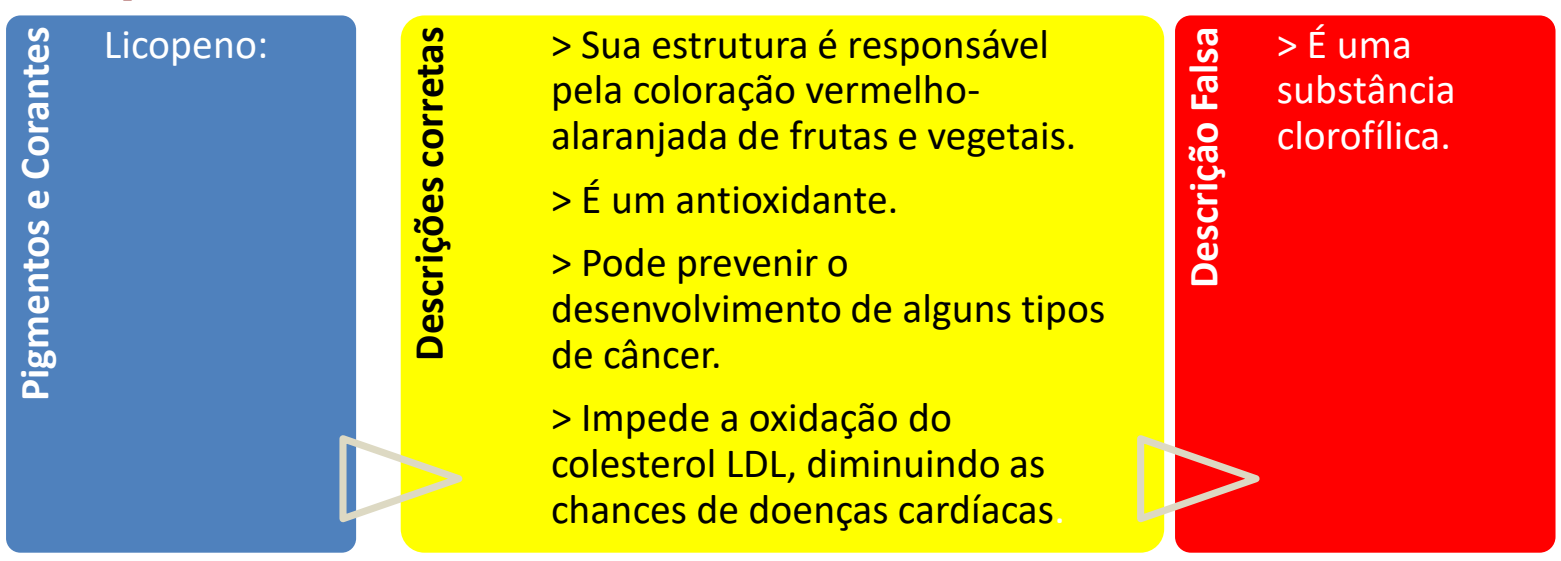

10 Xantofilas:
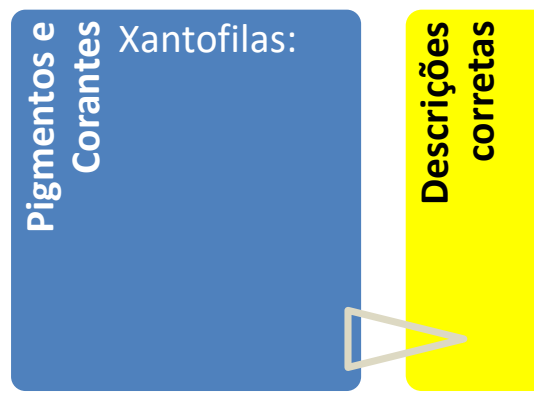

Formadas por carbono, hidrogênio e grupos oxigênio (hidroxilas ou cetonas, dentre outros).

É uma das principais divisões do carotenoide.

São pigmentos amarelos.

\section{1ํo Luteína:}

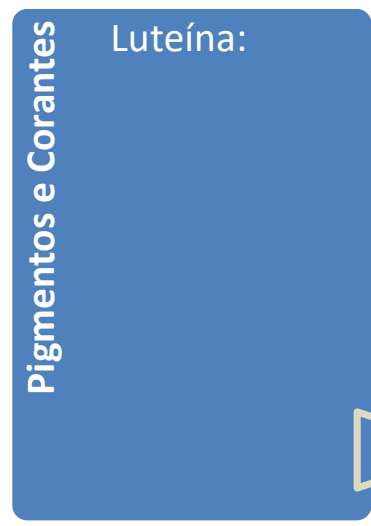

>É um carotenoide com pigmentação amarela.

$>$ É incapaz de o sintetizar, que pode ser encontrado em alimentos como milho, couve, ovo, dentre outros.

$>$ Previne o envelhecimento precoce, contribui para a proteção dos olhos contra os radicais livres.

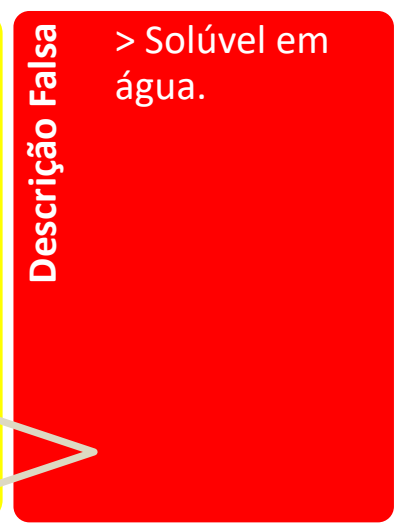

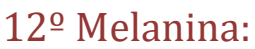

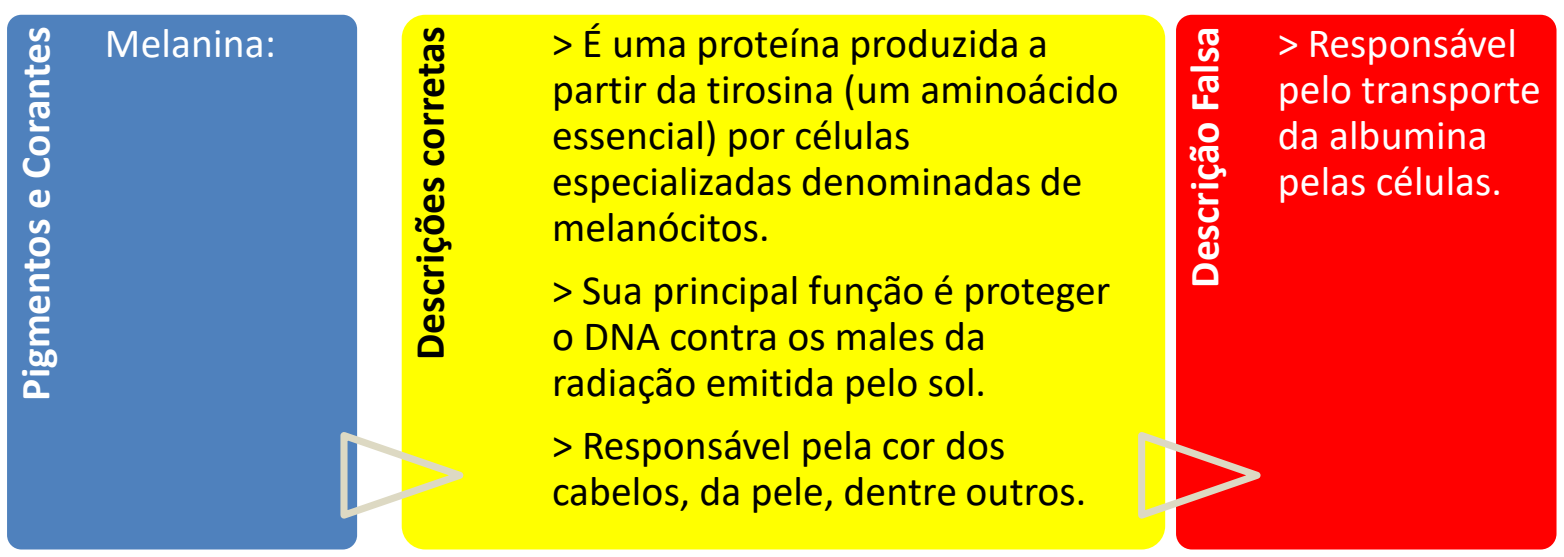


13을 Alizarina:

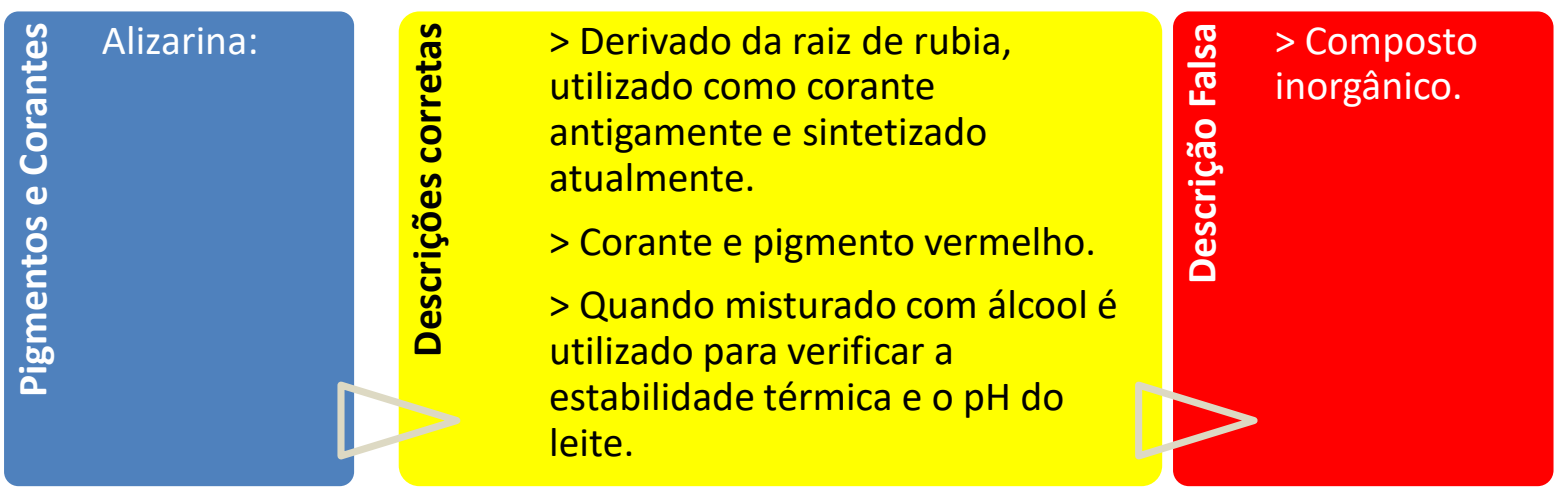

14 o E100 Curcumina:

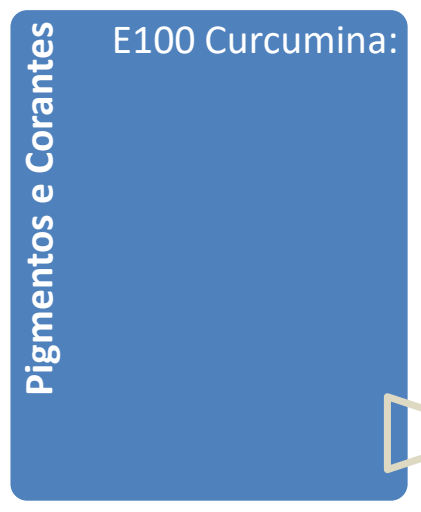

$>$ É um corante natural com atividades biológicas, sendo mais favorável que o sintético que provocam efeitos colaterais. $>$ É utilizado em para alimentos como um estimulante aromático.

> Apresenta a cor amarela.

\section{5ํㅡ102 Tartrazina}
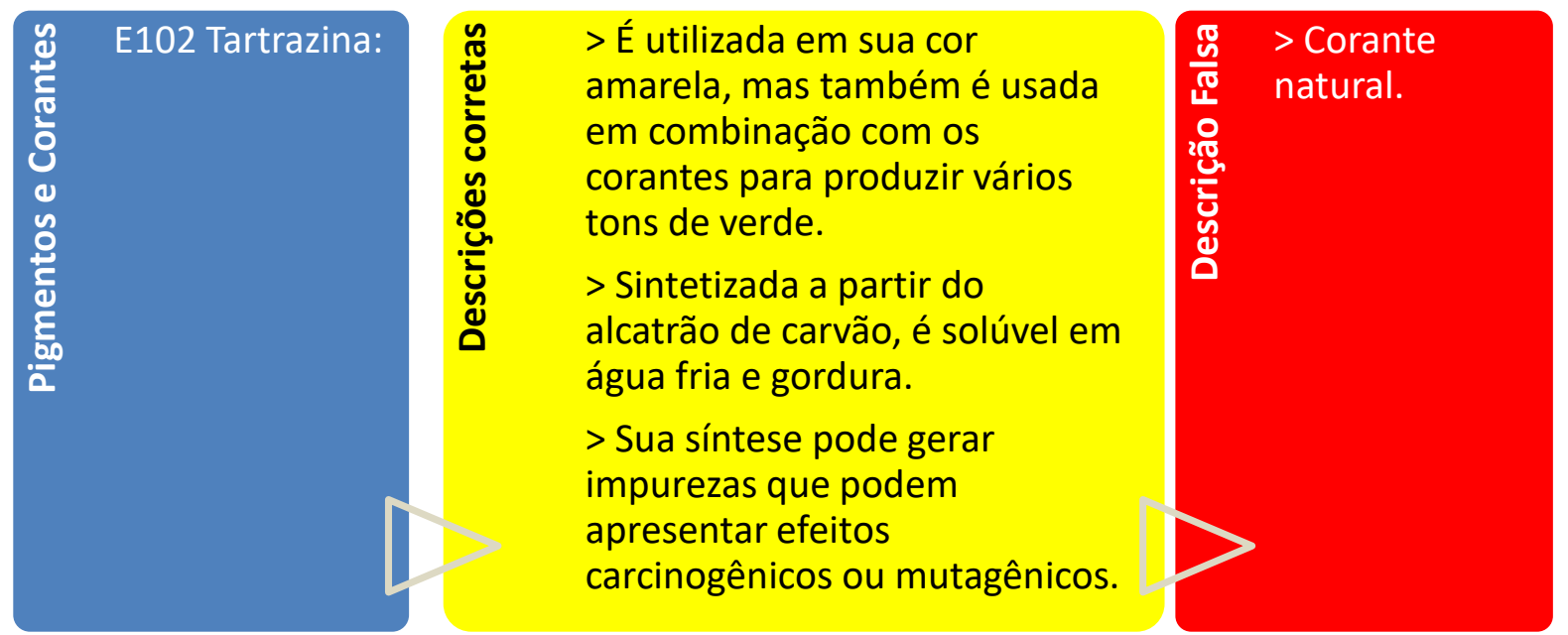
16을 E101 Riboflavina:

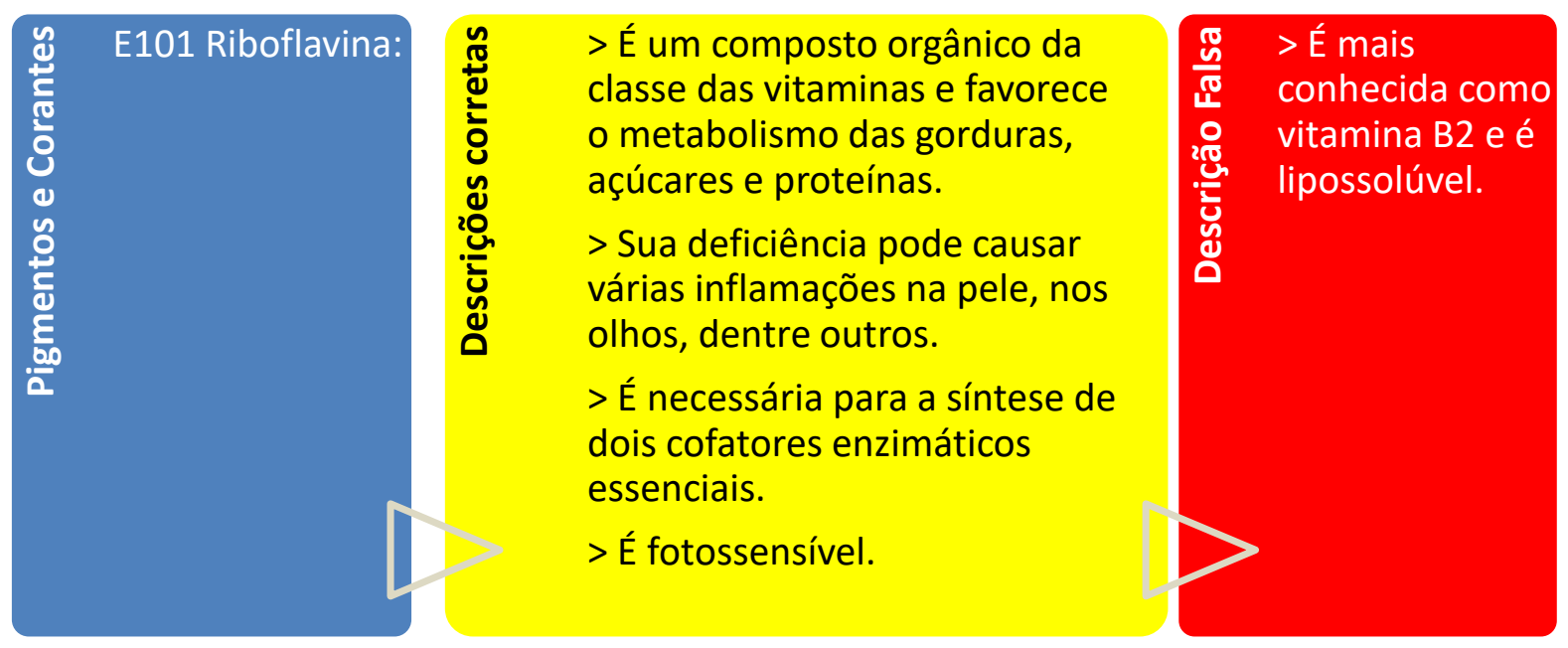

17을 E120 Cochonilha:

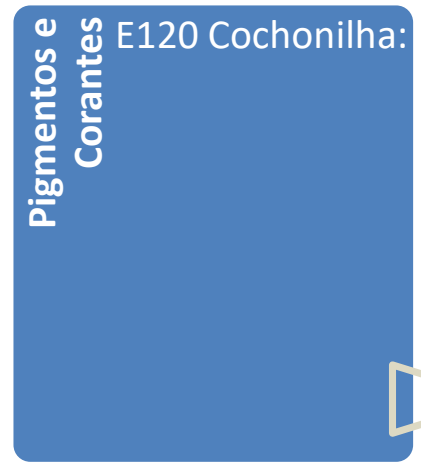
气 > $\quad>$ um corante carmim (vermelho escuro) muito utilizado na indústria de cosméticos, mas também alimentar.

> É conhecido e utilizado desde a antiguidade clássica.

$>$ É extraído de um animal.

18을 E127 Eritrosina:

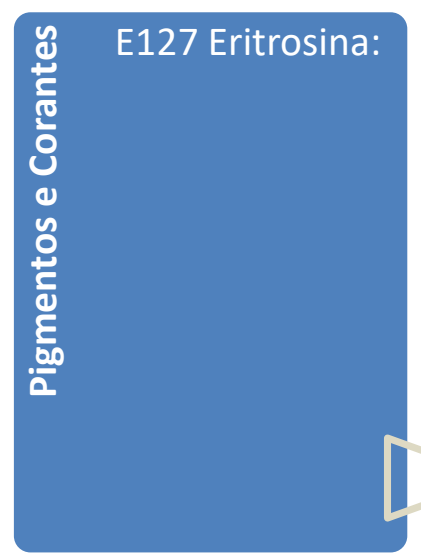

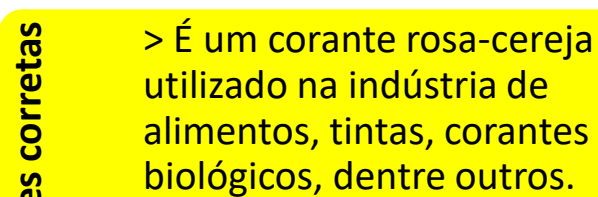

$>$ É usado como indicador de $\mathrm{pH}$ com ponto de viragem em $\mathrm{pH}$

2.2-3.6, variando da cor laranja para a vermelha.

> Pode ser carcinogênico e causar sensibilidade à luz.
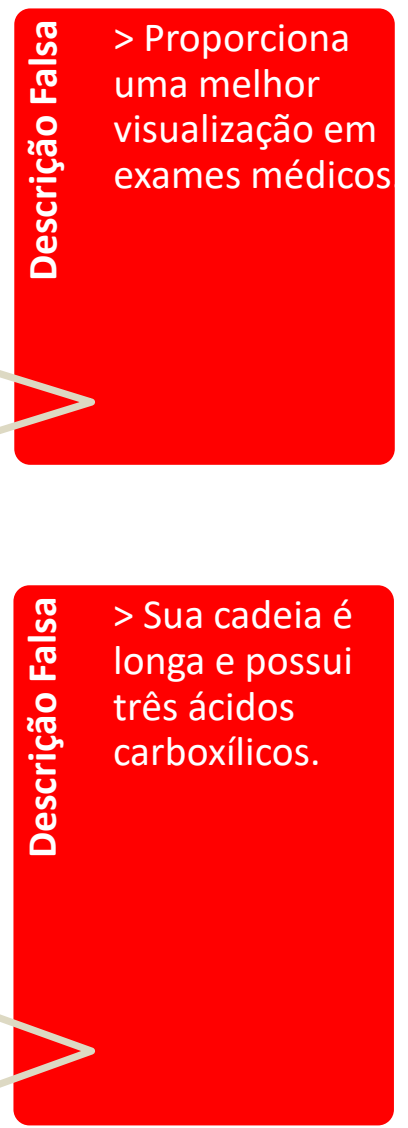
19 E133 Azul brilhante FCF:

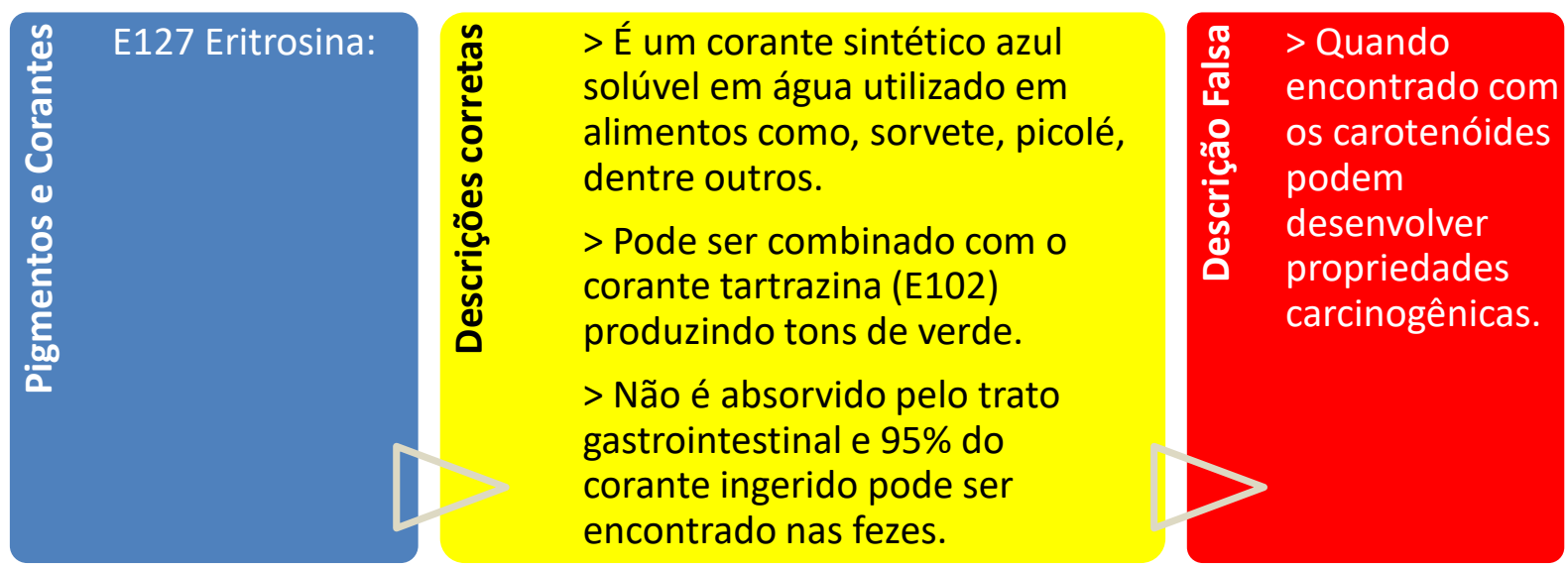

$20^{\circ}$ E150a Caramelo:

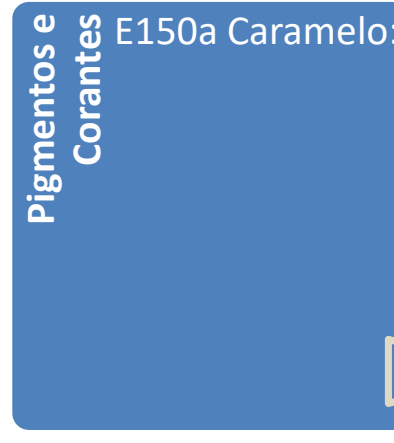

\begin{tabular}{|c|c|}
\hline 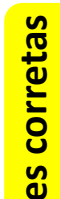 & $\begin{array}{l}>\text { É um corante cor } \\
\text { marrom/âmbar produzido } \\
\text { através da do aquecimento do } \\
\text { açúcar puro. }\end{array}$ \\
\hline & > Pode ser sintético ou orgânico. \\
\hline & $\begin{array}{l}\text { > Além de conferir coloração, } \\
\text { altera a percepção de aromas. }\end{array}$ \\
\hline
\end{tabular}

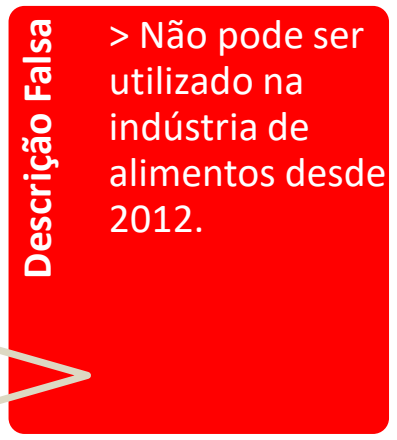

21 E160b Anato (colorau):
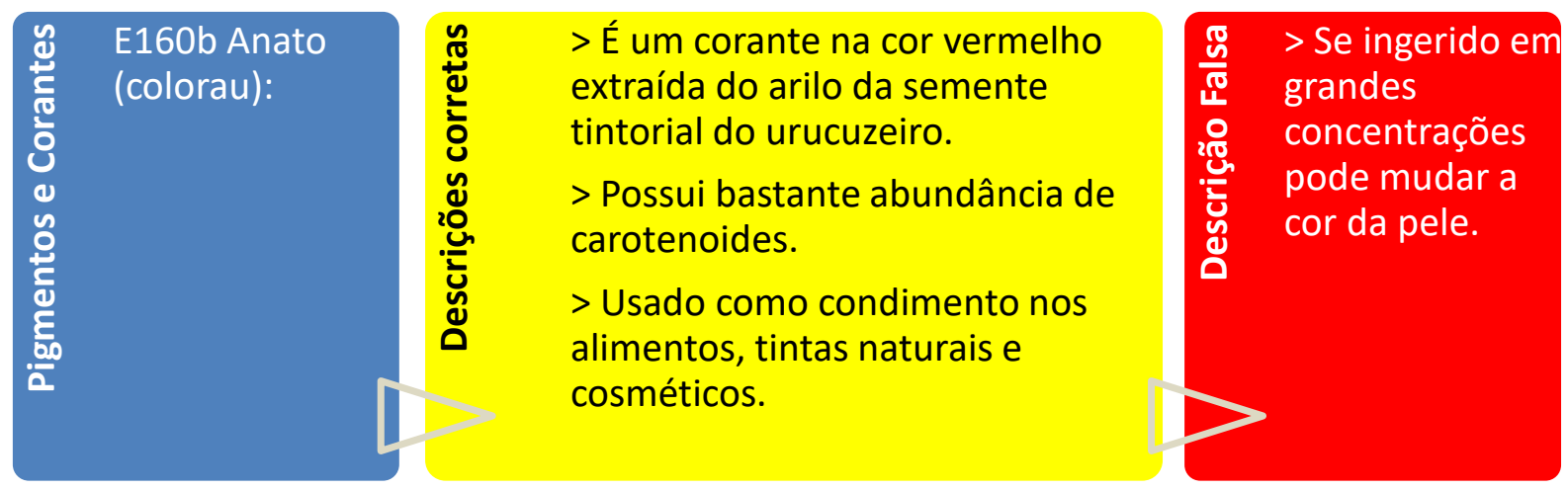

22 E173 Alumínio:

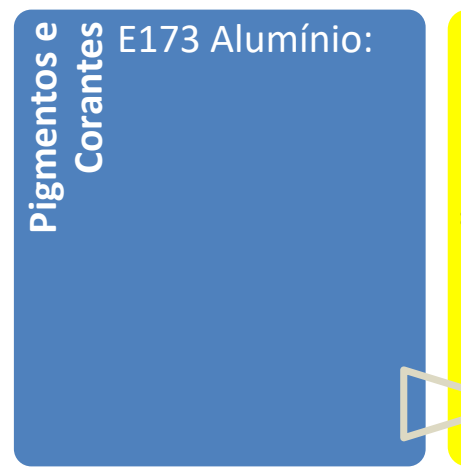

\begin{tabular}{|c|c|}
\hline 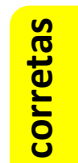 & $\begin{array}{l}\text { > Corante metálico para a } \\
\text { superfície de alimentos, obtido } \\
\text { do mineral bauxita. }\end{array}$ \\
\hline ע & $\begin{array}{l}\text { > É parcialmente absorvido nos } \\
\text { intestinos. }\end{array}$ \\
\hline 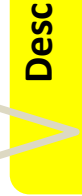 & $\begin{array}{l}\text { > Consideram prejudicial o } \\
\text { consumo excessivo que } \\
\text { proporciona o envelhecimento } \\
\text { celular. }\end{array}$ \\
\hline
\end{tabular}

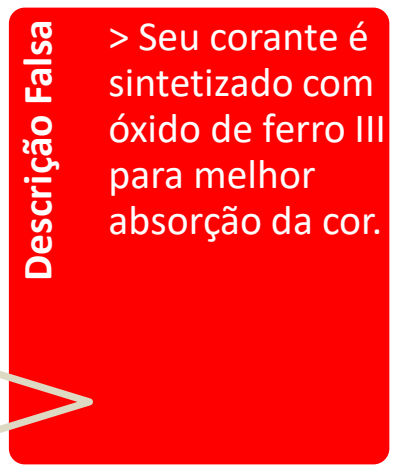




\section{$23^{\circ}$ E174 Prata:}
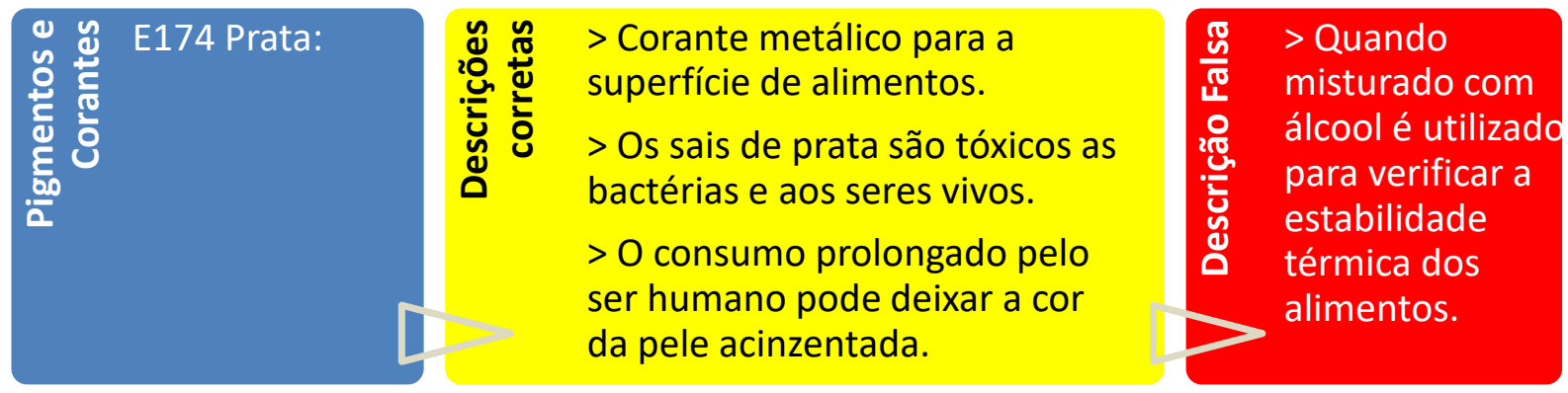

\section{4oㅡ Betalaína}
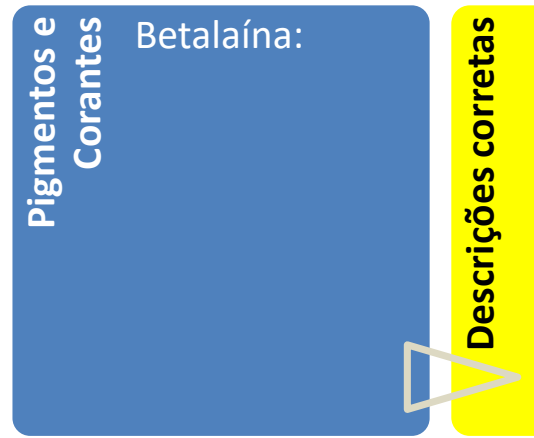

> São pigmentos encontrados principalmente na beterraba.

$>$ Apresentam comportamento e aparência semelhante às antocianinas.

$>$ Afetam positivamente a saúde com propriedades cardioprotetoras.

\section{REFERÊNCIAS}

[1] FARINA, Modesto. Psicodinâmica das cores em comunicação. 2ł. ed. São Paulo: Edgard Blücher, 1986.

[2] KISHIMOTO, T. M. Jogo, brinquedo, brincadeira e a educação. São Paulo: Cortez, 1996.

[3] NETTO, R. C. M. Dossiê corantes. FOOD INGREDIENTS BRASIL, n. 9, 2009. Disponível em: . Acesso em: 13 de.sept.2020.

[4] POLONI, R.; LUCA, M. Corantes naturais frentes às tendências mundiais. Periódico Tchê Química, v. 4, n. 7, p. 33-40, Porto Alegre, 2007. Disponível em:<http://www.deboni.he.com.br/tq/revista/revista7.htm> Acesso em: 13 de.sept.2020 .

[5] SOUZA, R. M. CORANTES NATURAIS ALIMENTÍCIOS E SEUS BENEFÍCIOS À SAÚDE. 2012. Monografia (Graduação Farmácia), Centro Universitário Estadual da Zona Oeste, Rio de Janeiro, 2012. Orientador: Professor Marco Antônio Mota e Professora Sabrina da Silva Dias.

[6] VELOSO, L. A. Corantes e Pigmentos - Dossiê Técnico. Serviço Brasileiro de Respostas Técnicas. Instituto de Tecnologia do Paraná, 2012. 


\section{Jogo 14}

\section{Jogo do impostor 2 (Pigmentos e Corantes)}

\section{Itamara Gomes de Sousa}

Maria da Conceição Tavares Cavalcanti Liberato 


\section{INTRODUÇÃO}

Usar ferramentas diferentes para uso no ensino e aprendizagem do conteúdo de química tem-se tornado realidade, sendo um assunto amplamente discutido na comunidade acadêmica e nas escolas, pois é uma matéria considerada pelos alunos como complicado e decorativa. (ALCÂNTARA, 2019). Segundo Teixeira e Apresentação (2015), é por meio de jogos que os alunos constroem suas experiencias de forma mais ativa e eficiente, já que a maioria são geralmente de ajuda mútua e análise de erro e sucesso, fornecendo uma reflexão sobre o conceito que o professor pretende discutir em sala e estimulando a aprendizagem através dessas reflexões. 0 jogo tem como objetivo principal o ensino do conteúdo de pigmentos e corantes de forma lúdica e divertida para que possa ser usado como apoio metodológico.

\section{MATERIAIS E MÉTODOS}

0 jogo se trata de uma adaptação do TWISTER HASBRO com a proposta de estimular os jovens a praticar exercício físico e mental. 0 jogo Twister se trata de um tapete no tamanho 1,40m x 1,70m com 4 fileiras de 4 cores (verde, amarelo, azul e vermelho) cada fileira contém 6 círculos nessas mesmas cores. Além do tapete tem também uma roleta com os direcionamentos mão direita, mão esquerda, pé esquerdo e pé direito e as cores verde, amarelo, azul e vermelho. 0 jogo funciona da seguinte forma: dois jogadores jogam por vez, cada um gira a roleta e obedece ao direcionamento, ganha quem permanecer no tapete sem cair. 0 jogo a seguir, tem o mesmo seguimento com uma proposta diferente. Em cada círculo das quatro cores temos o nome de um corante ou pigmento, nas cores indicadas e uma pequena descrição do mesmo, assim, o aluno poderá exercitar o corpo e ao mesmo tempo aprender sobre pigmentos e corantes. Como adaptação da roleta temos dois dados. 0 dado 1 mostra que membro usar (mão direita, mão esquerda, pé esquerdo e pé direito) e o dado 2 mostra as cores dos círculos (verde, amarelo, azul e vermelho). Sabe-se que é muito importante procurar novos métodos lúdicos para buscar o interesse de nossos alunos visto que as disciplinas de ciências da natureza são vistas com menor interesse da parte desses discentes.

\section{Para confeccionar o tapete}

- É necessário imprimir os círculos

- TNT tamanho 1,40m x 1,70m (dependendo do tamanho do espaço em que será usado pode ser confeccionado em um tamanho menor)

- Para confeccionar o dado

- Imprimir o dado 1 para indicar os direcionamentos pé direito, pé

- esquerdo, mão direita e mão esquerda.

- Imprimir o dado 2 para indicar as cores a serem seguidas. 


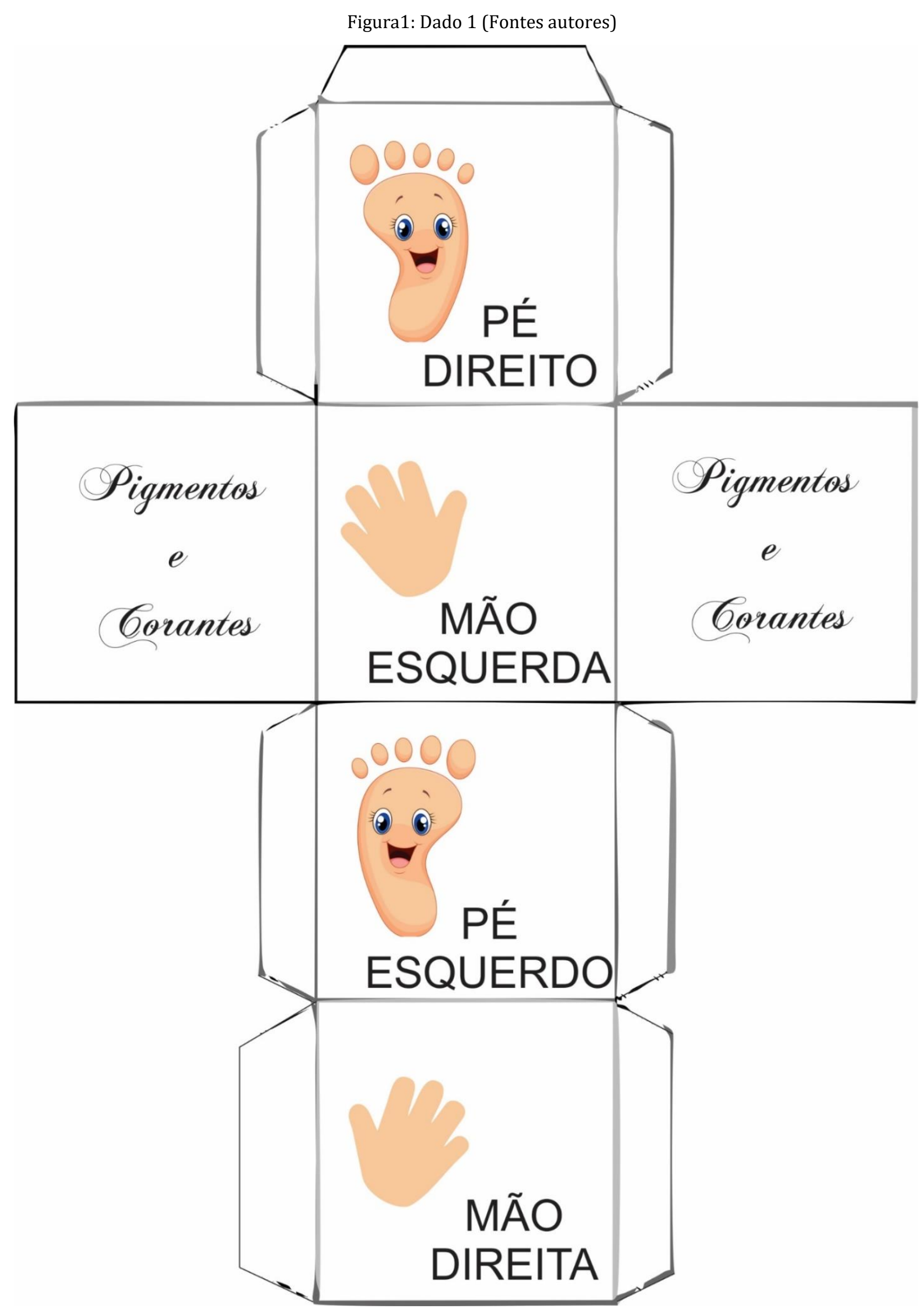


Figura 2: Dado 2 (Fonte autores)

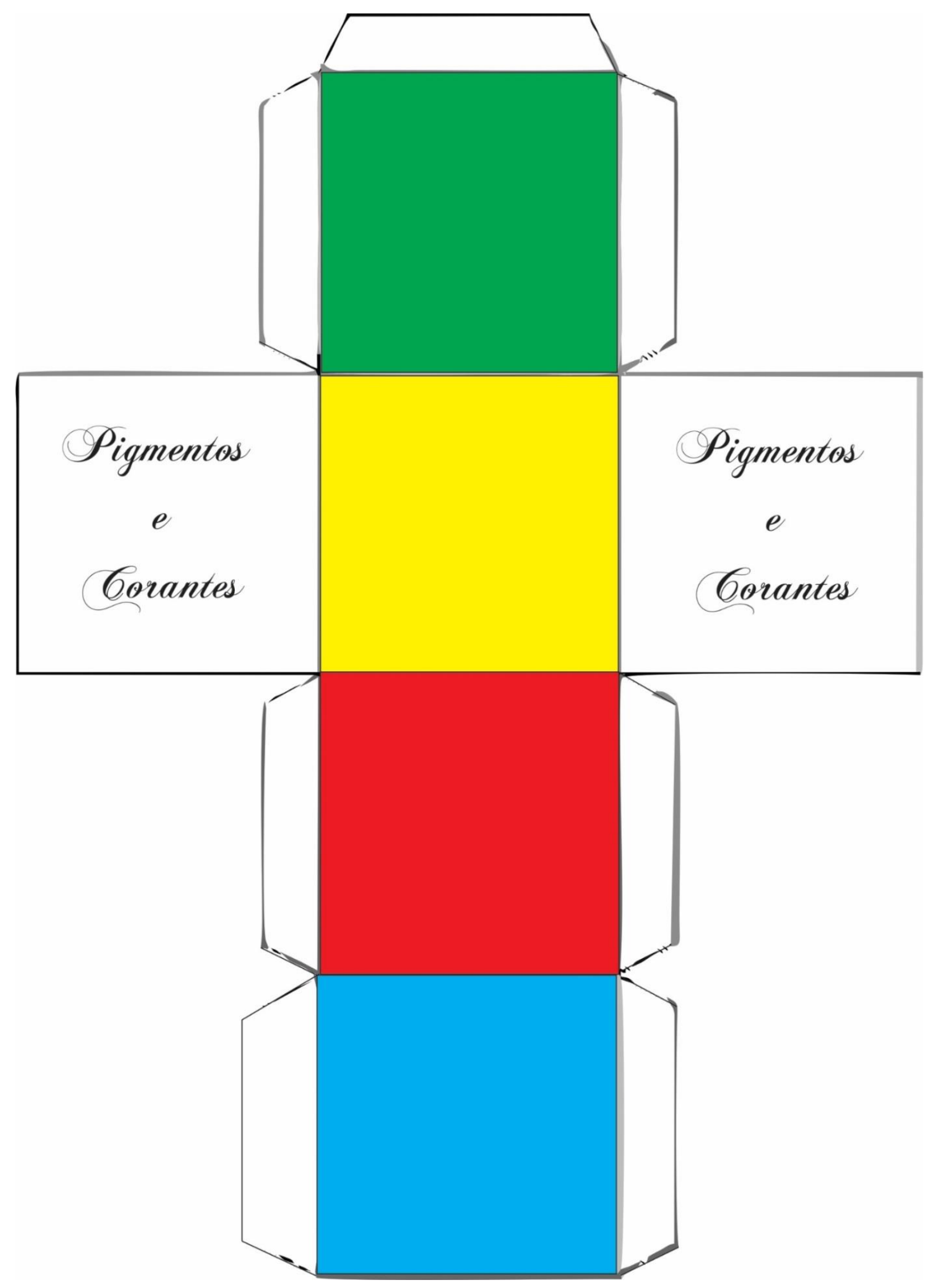


Figura 3:Tabuleiro (Fonte:autores)

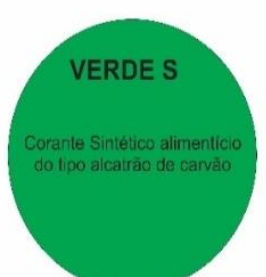

AMARELO CREPÚSCULO

Corante alimenticio

de fórmula

C16H10N2Na2O7S2
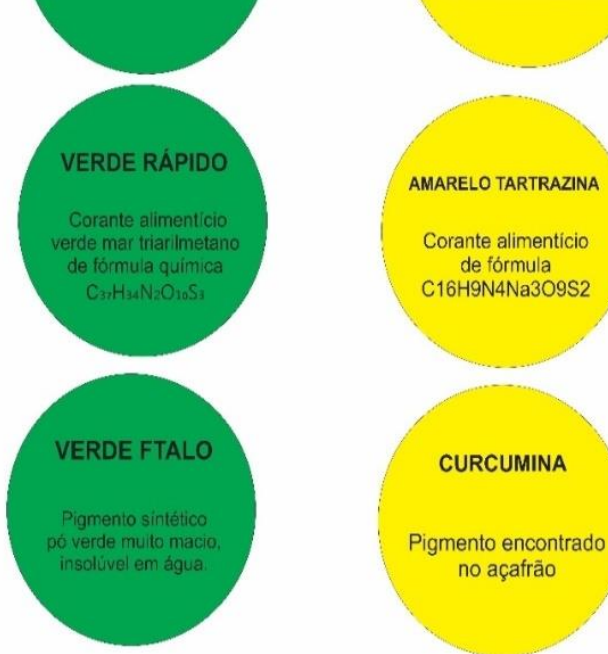

AMARELO TARTRAZINA

Corante alimenticio

de fórmula

C16H9N4Na3O9S2
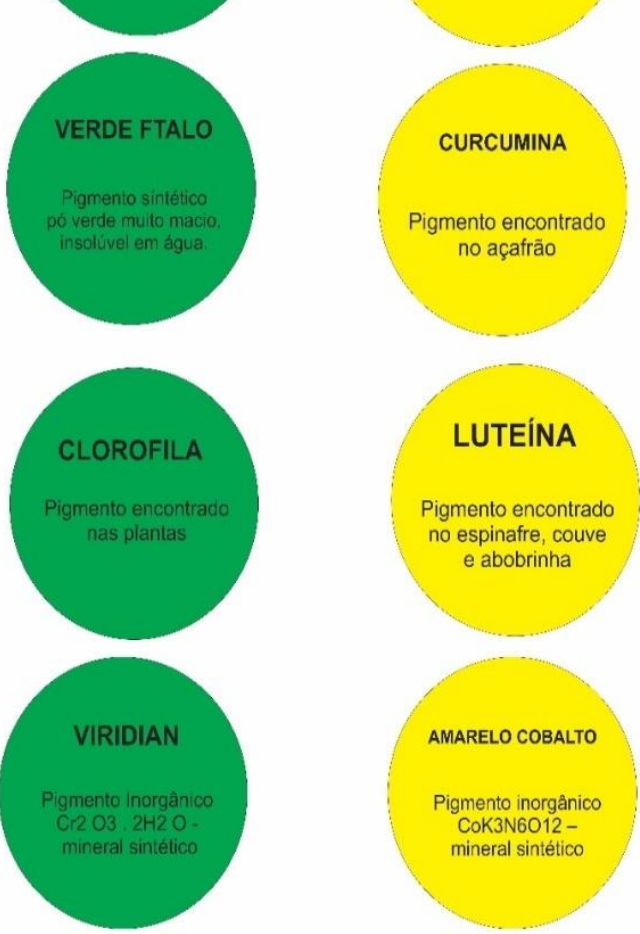

no açafrāo

VERDE
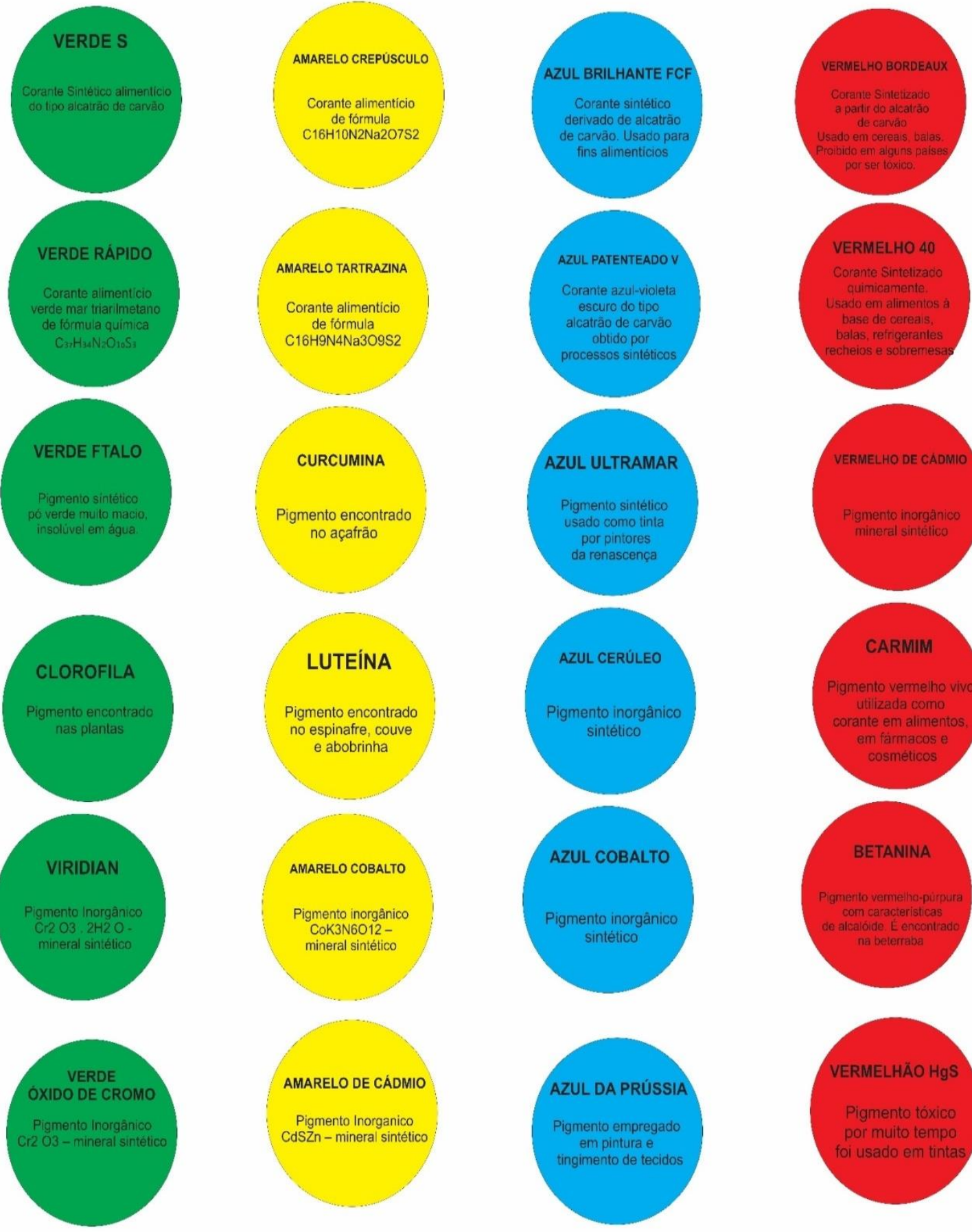

alcatrâo de can

obtido por
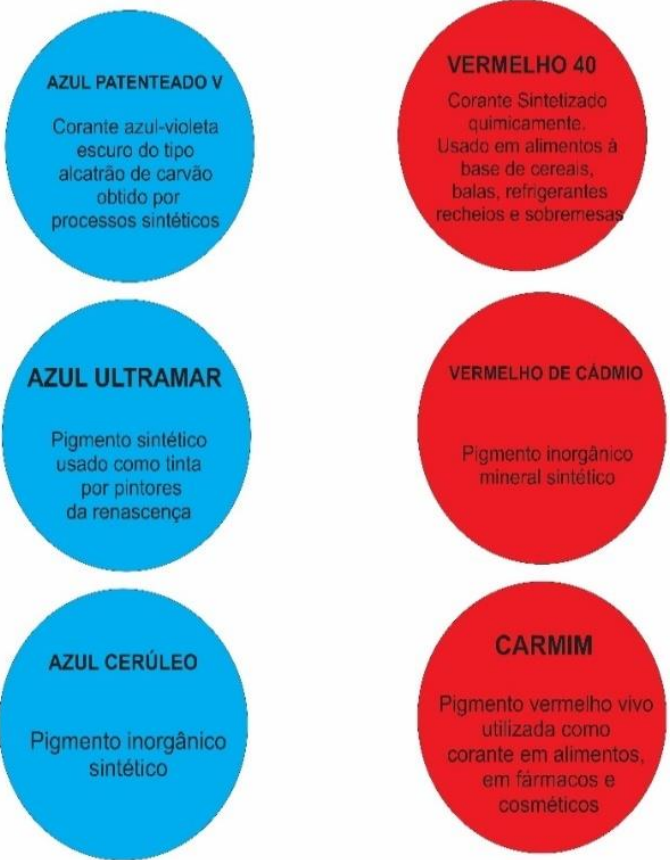

CARMIM

\section{LUTEÍNA}

Pigmento encontrado

no espinafre, couve

e abobrinha
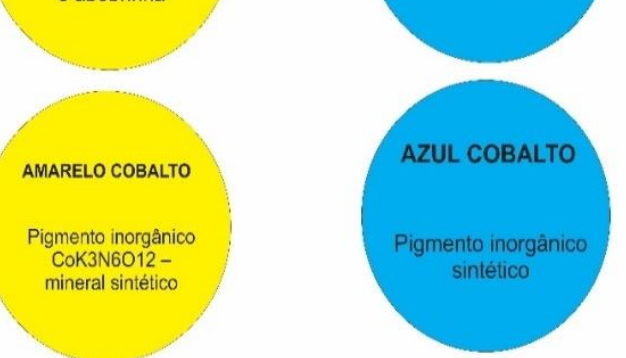

\section{Pigmento inorgânico mineral sintético \\ AMARELO COBALTO}

AMARELO DE CÁDMIO

Pigmento Inorganico CdSZn - mineral sintético
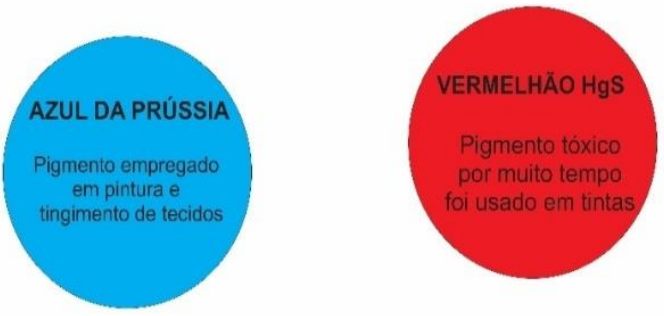
Figura 4: Peças do tabuleiro verdes
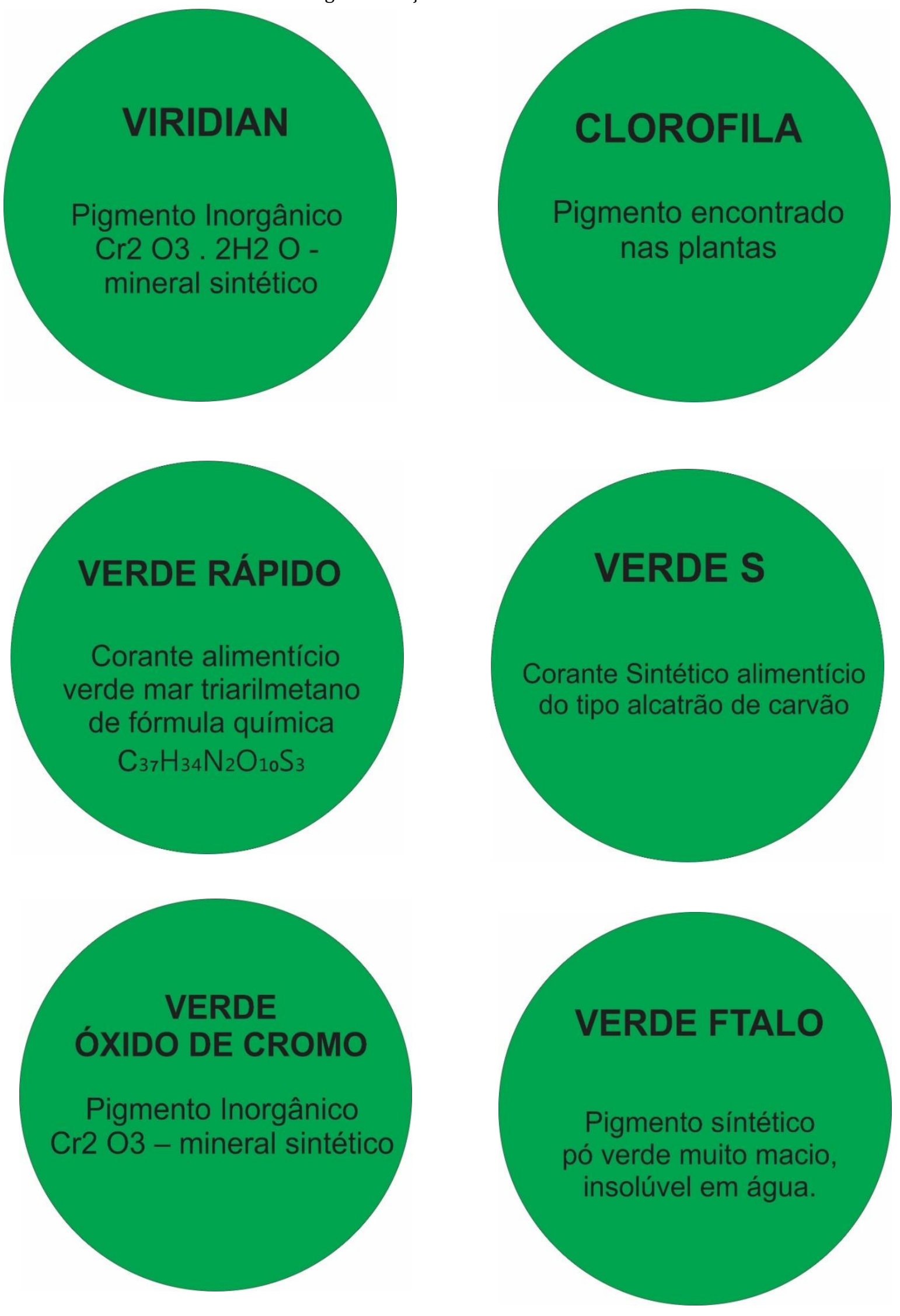


\section{AMARELO DE CÁDMIO}

Pigmento Inorganico

CdSZn - mineral sintético

\section{LUTEÍNA}

Pigmento encontrado no espinafre, couve e abobrinha
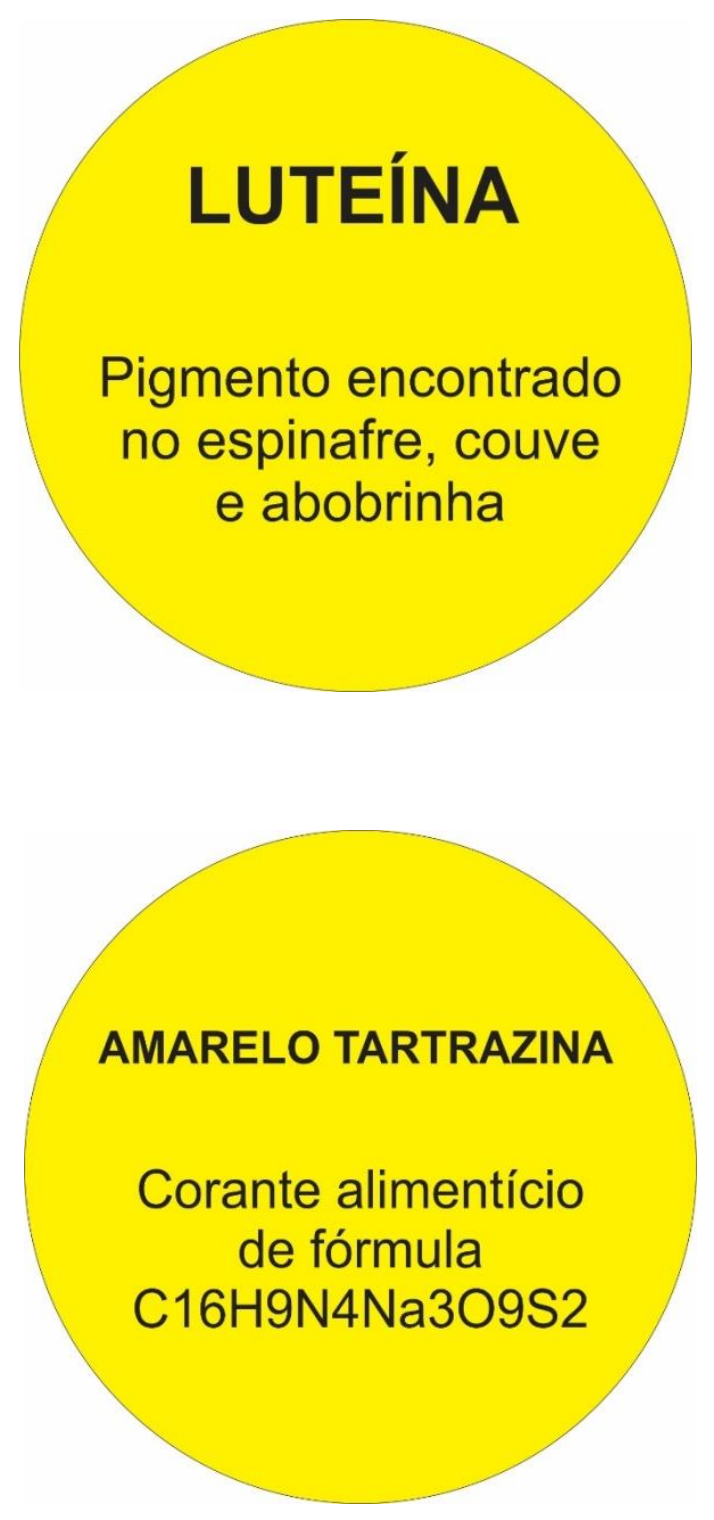

\section{AMARELO COBALTO}

Pigmento inorgânico CoK3N6O12 mineral sintético

\section{CURCUMINA}

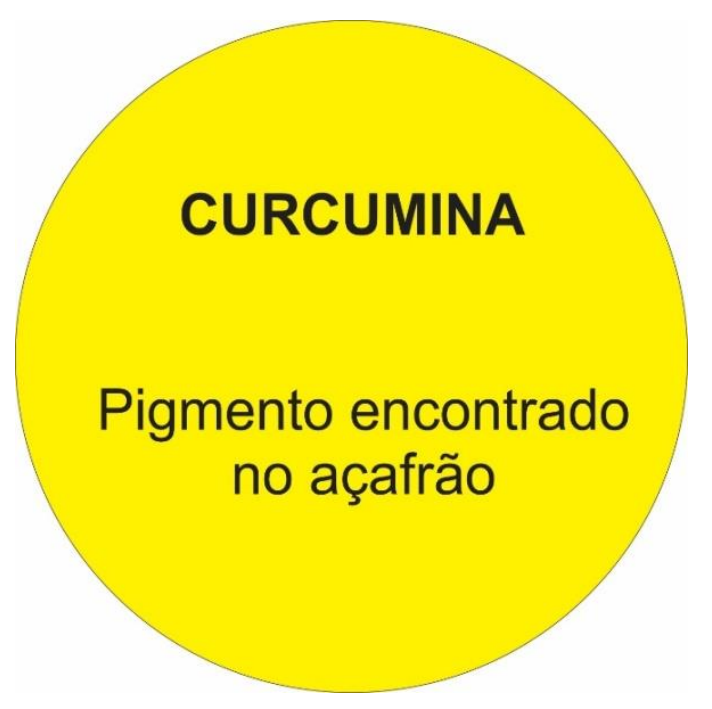



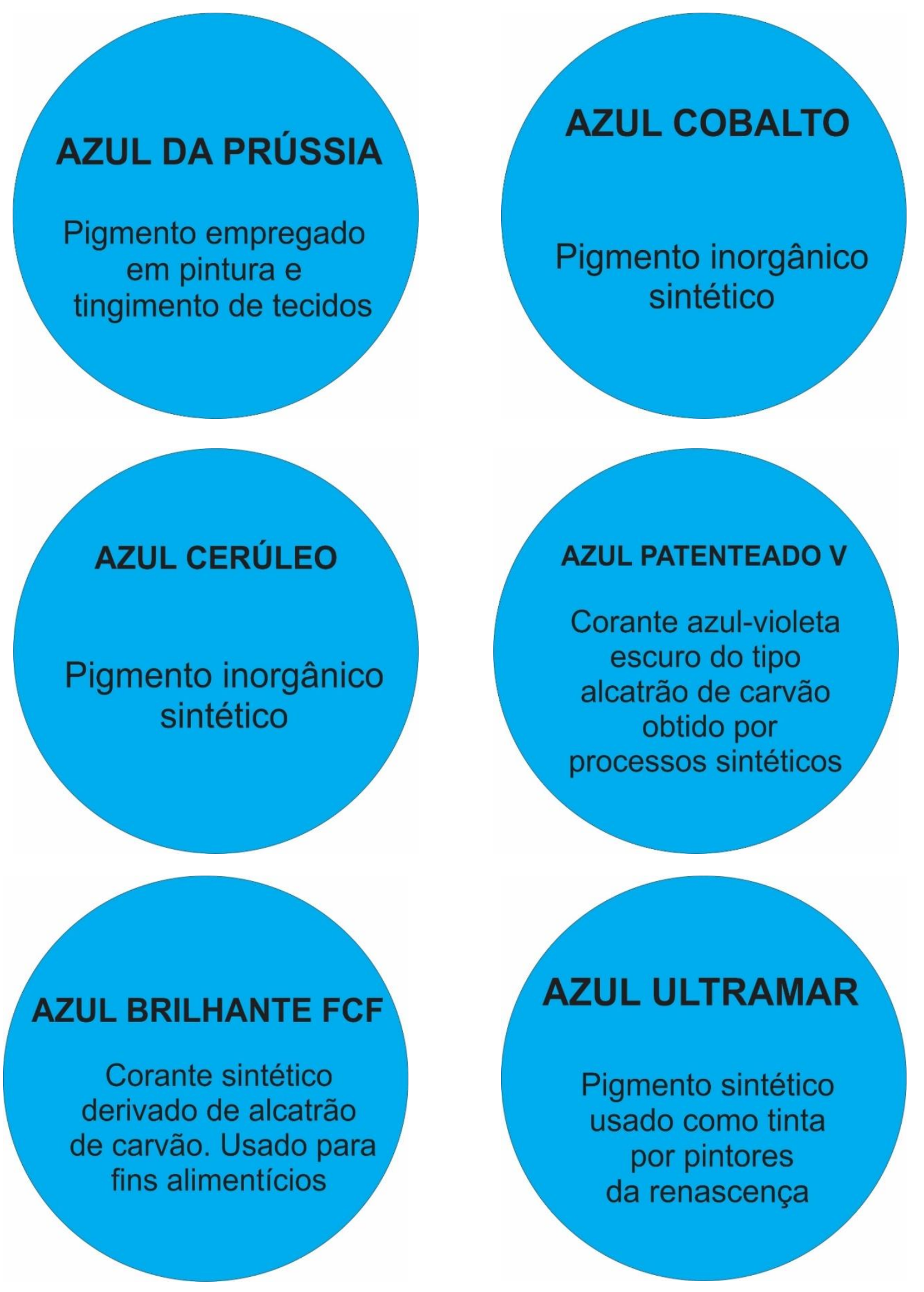
Figura 6: Peças do tabuleiro vermelho (Fonte autores)
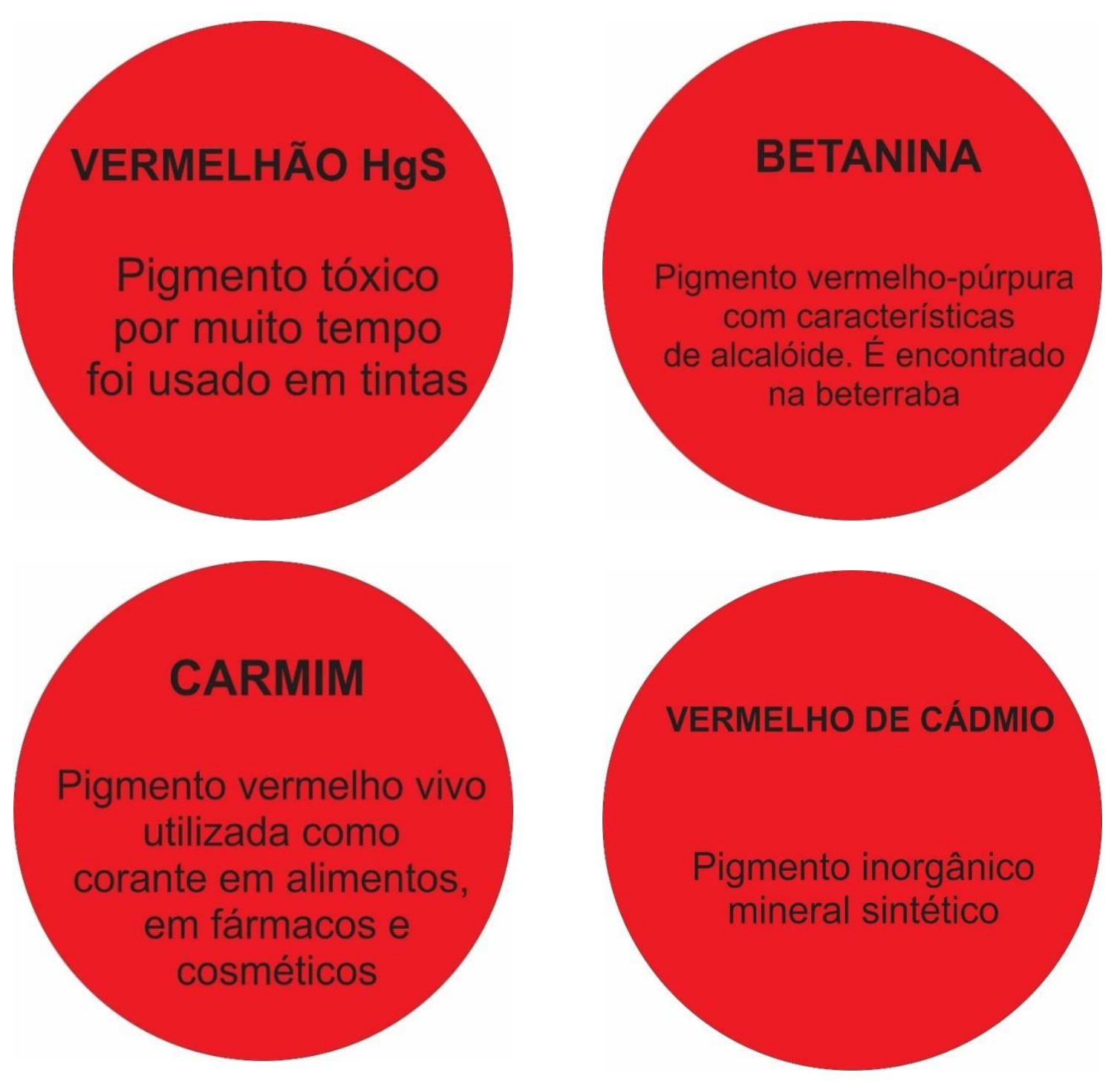


\section{REFERÊNCIAS}

[1] BARCELOS, João. Cores e Pigmentos. Disponível em: <http://www.joaobarcelos.com.br/cap2.pdf> Acesso em: 26 jan. 2021

[2] QUALI. Lista de corantes. In: Quali. Aditivos alimentares. [Portugal]: Quali,2018. Disponível em: https://www.quali.pt/aditivos-alimentares/500-lista-corantes. Acesso em: 26 jan. 2021

[3] VERDE S. In: WIKIPÉDIA: a enciclopédia livre. Disponível em: https://pt.wikipedia.org/wiki/Verde_S. Acesso em: 26 jan. 2021

[4] VERDE FTALOCIANINA G. In: WIKIPÉDIA: a enciclopédia livre. Disponível em: https://pt.wikipedia.org/wiki/Verde_ftalocianina_G. Acesso em: 26 jan. 2021

[5] CARMIM. In: WIKIPÉDIA: a enciclopédia livre. Disponível em: https://pt.wikipedia.org/wiki/Carmim. Acesso em: 26 jan. 2021

[6] VERMELHÃO. In: WIKIPÉDIA: a enciclopédia livre. Disponível em: https://pt.wikipedia.org/wiki/Vermelh\%C3\%A3o. Acesso em: 26 jan. 2021

[7] VECTORSTOCK. Cartoon happy smile foot vector image. Cartoon vectors. Disponível em: https://www.vectorstock.com/royalty-free-vector/cartoon-happysmile-foot-vector-5610602. Acesso em: 26 jan. 2021

[8] ALCÂNTARA, Otilia Alves De et al.. O lúdico como auxílio para aprendizagem de química dos alimentos. Anais VI CONEDU- Congresso Nacional de Educação Campina Grande: Realize 2019.2 Disponível em: <https://editorarealize.com.br/artigo/visualizar/61471>. Acesso em: 25/03/2021

[9] TEIXEIRA, Ricardo Roberto Plaza; APRESENTAÇÃO, Katia Regina dos Santos da. Jogos em sala de aula e seus benefícios para a aprendizagem da matemática. Revista Linhas, Florianópolis, v. 15, n. 28, p. 302-323, 6 jan. 2015. Universidade do Estado de Santa Catarina. Disponível em: https://doi.org/10.5965/1984723815282014302. Acesso em: 20 mar. 2021. 


\section{Jogo 15}

\section{Pigcolor \\ Alimentos em cores}

Milena Lira Rocha

Camile Rabelo de Medeiros

Cecília Guimarães Lemos

Vitória Ellen Lima Bantim

Maria Da Conceição Tavares Cavalcanti Liberato 


\section{INTRODUÇÃO}

0 uso de jogos e atividades lúdicas no meio educacional é um dos recursos metodológicos que podem contribuir com o processo de ensino e aprendizagem, tendo em vista que suas aplicações podem despertar o interesse e a curiosidade dos alunos, melhorando o desempenho e habilidades cognitivas dos mesmos, além disso, torna o aprendizado mais dinâmico e prazeroso (KIYA, 2014).

Nessa perspectiva, o professor assume um papel importante em desenvolver e/ou aplicar jogos lúdicos em sala de aula, tendo em vista que um dos principais objetivos a ser atingido, é fazer com que os alunos associem o lúdico ao conteúdo ministrado pelo educador e dessa forma o jogo passa a ser um recurso didático por se tornar uma ferramenta metodológica diferenciada (RÊGO, JUNIOR, ARAÚJO, 2017).

Diante ao exposto, o tema Química dos Alimentos é um dos assuntos explorado em Química Orgânica e faz abordagens sobre pigmentos e corantes que são substâncias colorantes presentes em vários produtos alimentícios. O estudo, identificação e compreensão das funcionalidades dessas substâncias nos alimentos é de suma importância para a saúde humana e os hábitos alimentares.

Nesse sentido, BRACH (2014) ressalta que utilizar recursos metodológicos lúdicos para dinamizar a aprendizagem e ajudar os estudantes a desenvolverem a capacidade de entender conceitos químicos, e aplicá-los em contextos específicos, é também uma forma inovadora de fazerem construir o próprio aprendizado. A utilização do jogo de cartas sobre pigmentos e corantes em contexto de sala de aula como um jogo educativo e lúdico elaborado neste trabalho, tem como principal objetivo tornar visual para os alunos os mais variados produtos alimentícios que contém algum tipo de substância colorante em sua composição, bem como, fazer com que identifiquem e relacionem os respectivos alimentos aos nomes e as categorias dos corantes e pigmentos.

\section{METODOLOGIA}

O presente trabalho foi desenvolvido na Universidade Estadual do Ceará (UECE), localizada em Fortaleza/CE, realizado por quatro alunas do curso de Química da UECE. 0 trabalho foi feito para alunos de ensino fundamental e médio.

0 trabalho foi dividido em três etapas:

- Na primeira etapa: planejamento do trabalho, foi feito um estudo sobre pigmentos e corantes alimentícios. Teve-se um embasamento teórico para em seguida escolher as regras do jogo.

- Na segunda etapa realizaram-se as regras do jogo.

- Na terceira etapa, realizou-se a elaboração das cartas do jogo pelo o aplicativo Canva, onde as cartas foram produzidas com um design colorido e lúdico para tornar mais divertido e atrativo de jogar.

\section{$\underline{\text { Regras do jogo }}$}

0 jogo PigColor - Alimentos em Cores pode ser jogado da seguinte forma:

- Pode-se jogar até seis pessoas, cada pessoa fica com quatro cartas da Categoria 1.

- Em seguida utiliza-se o dado no começo do jogo para decidir a ordem de cada jogador.

- As cartas são compostas por 3 categorias: 


\section{Categoria 1}

- Carta Azul: Alimentos e os nomes referente aos corantes e pigmentos de cada alimento;

\section{Categoria 2:}

Cartas Vermelhas, Verdes e Azuis claro:

- Corantes e a classe a qual cada um pertence (Sintético, artificial ou Natural).

- Cartas Amarelas: Pigmentos e a classe a qual cada um pertence (Natural);

\section{Categoria 3:}

Cartas Pretas: Coringas para dinamizar o jogo.

O jogo tem 75 cartas no total, onde 66 cartas são para alimentos, corantes e pigmentos, e 9 cartas são coringas. As cartas de alimentos são todas diferentes, mas as cartas de corantes e pigmentos contêm repetidas, pois existem alimentos com o mesmo corante ou pigmento, por isso há repetição de cartas. As cartas coringas também contêm repetidas, possuem três cartas ( +2$)$, três cartas de inverter a ordem do jogo $(\leftarrow \rightarrow)$ e três cartas de bloqueio $(Q)$.

As cartas coringas podem alterar a ordem, bloquear a jogada de um participante ou aumentar a quantidade de cartas dos jogadores durante o jogo, os exemplos de cartas são: cartas (+2), significa que o jogador que puxou essa carta puxará mais duas cartas; cartas $(\leftarrow \rightarrow)$ significa que o jogador que puxou alterará a ordem do jogo; $\operatorname{cartas}(\theta)$ significa que o jogador que puxou essa carta bloqueará o próximo jogador.

Para cada carta da Categoria 1 existe uma carta da categoria 2 correspondentes. 0 jogador que puxar uma carta da categoria 2 deve observar se esta relaciona-se com alguma carta da categoria 1 que está na sua mão. Exemplo: 0 jogador possui uma carta do alimento Cenoura na mão, quando for sua vez de jogar, deve-se puxar uma carta da categoria 2. Se a carta puxada conter o pigmento presente na carta do alimento Cenoura, este jogador pode descartar sua carta de alimento. Caso contrário o jogador passará a vez.

O jogo acaba quando um primeiro jogador descartar todas suas cartas de alimentos. 
CARTAS CATEGORIA I
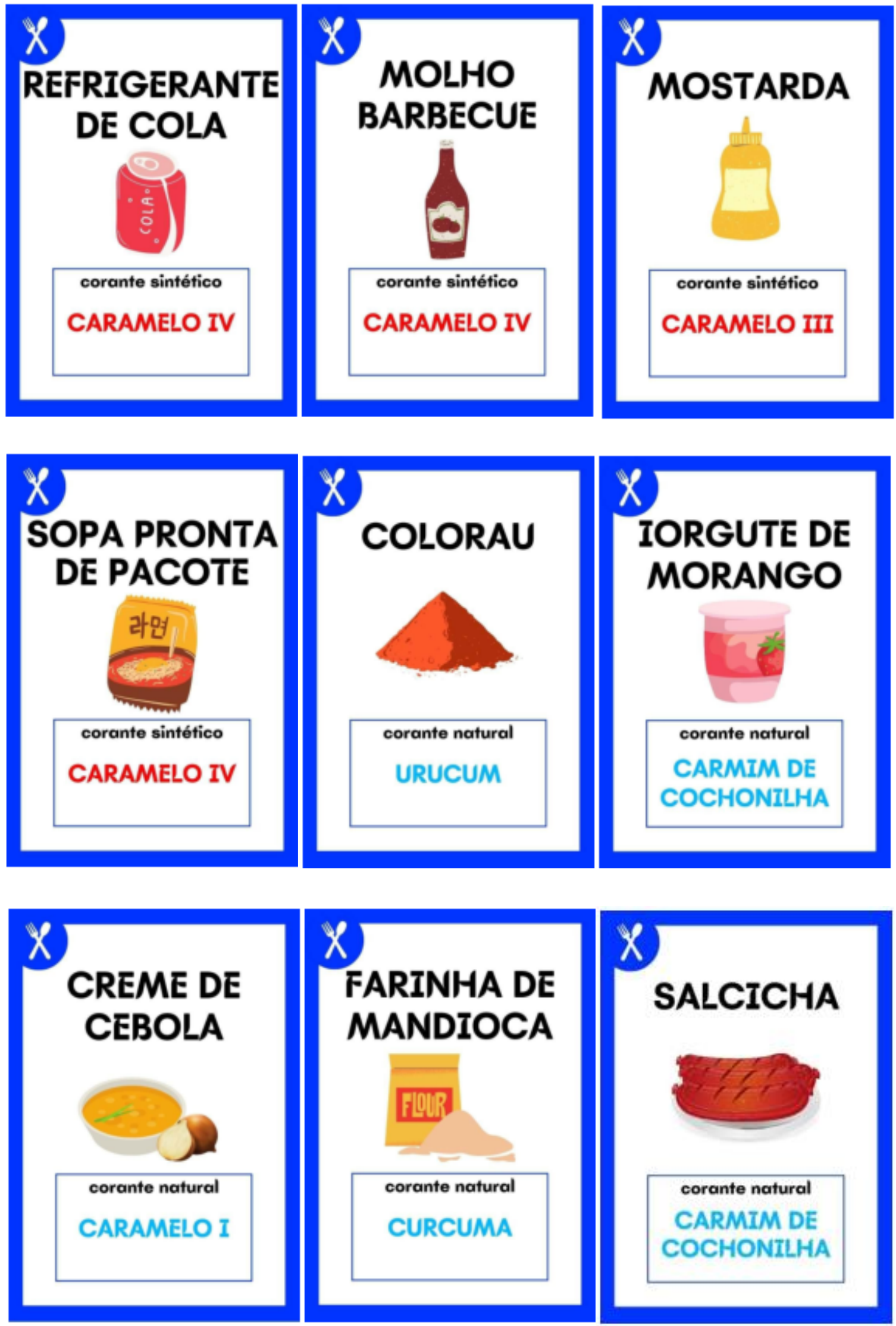

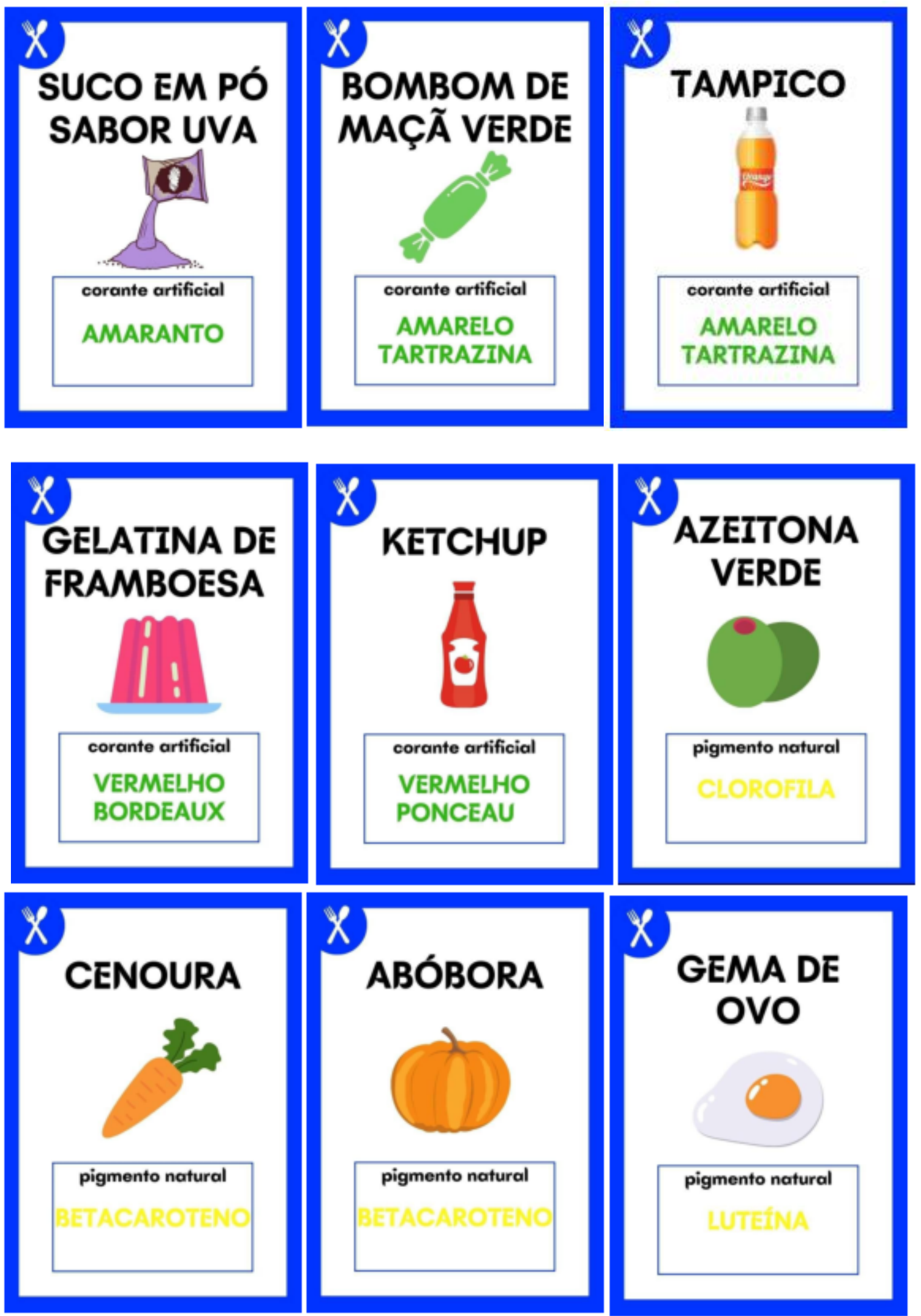

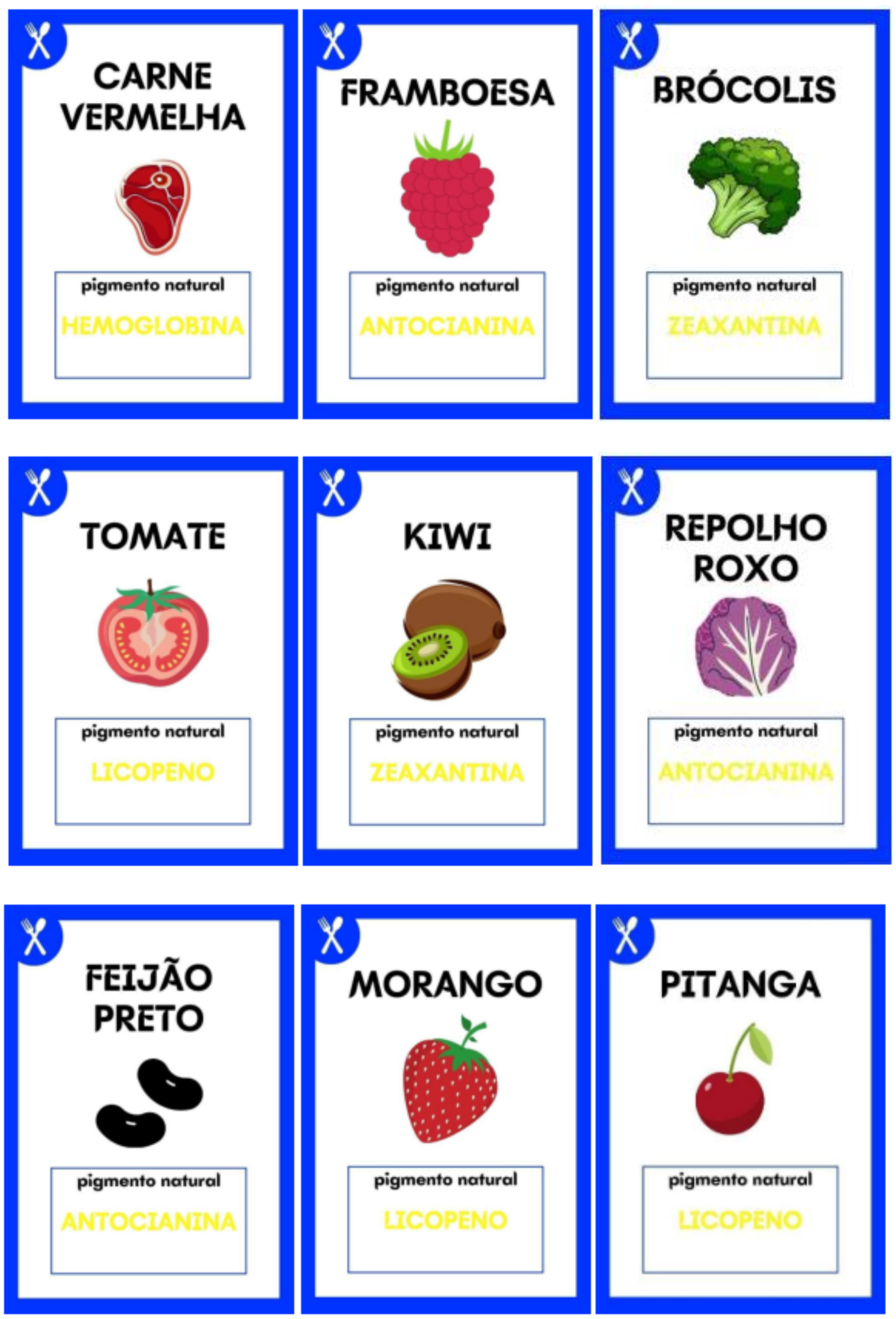

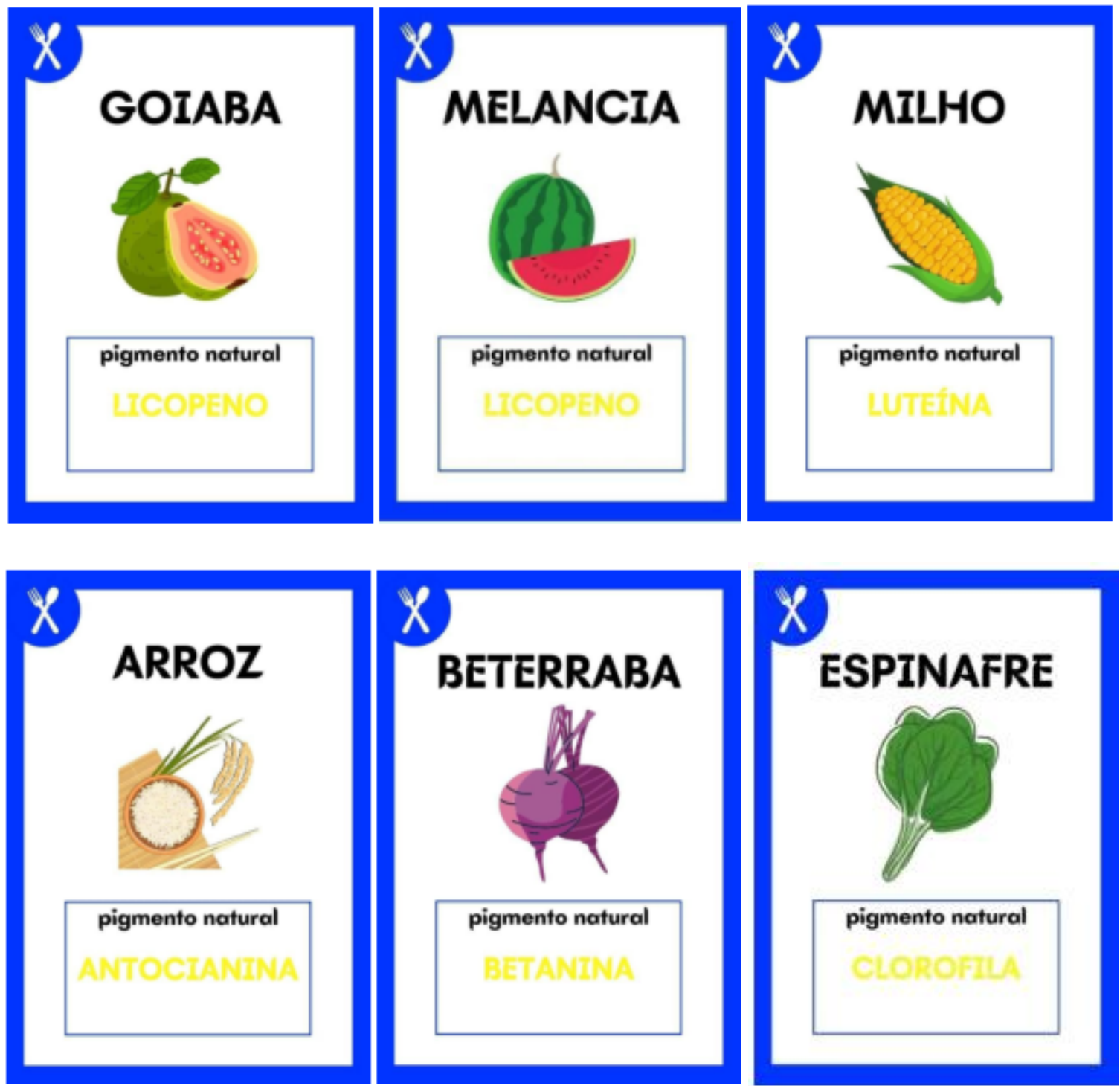


\section{CARTAS CATEGORIA II}
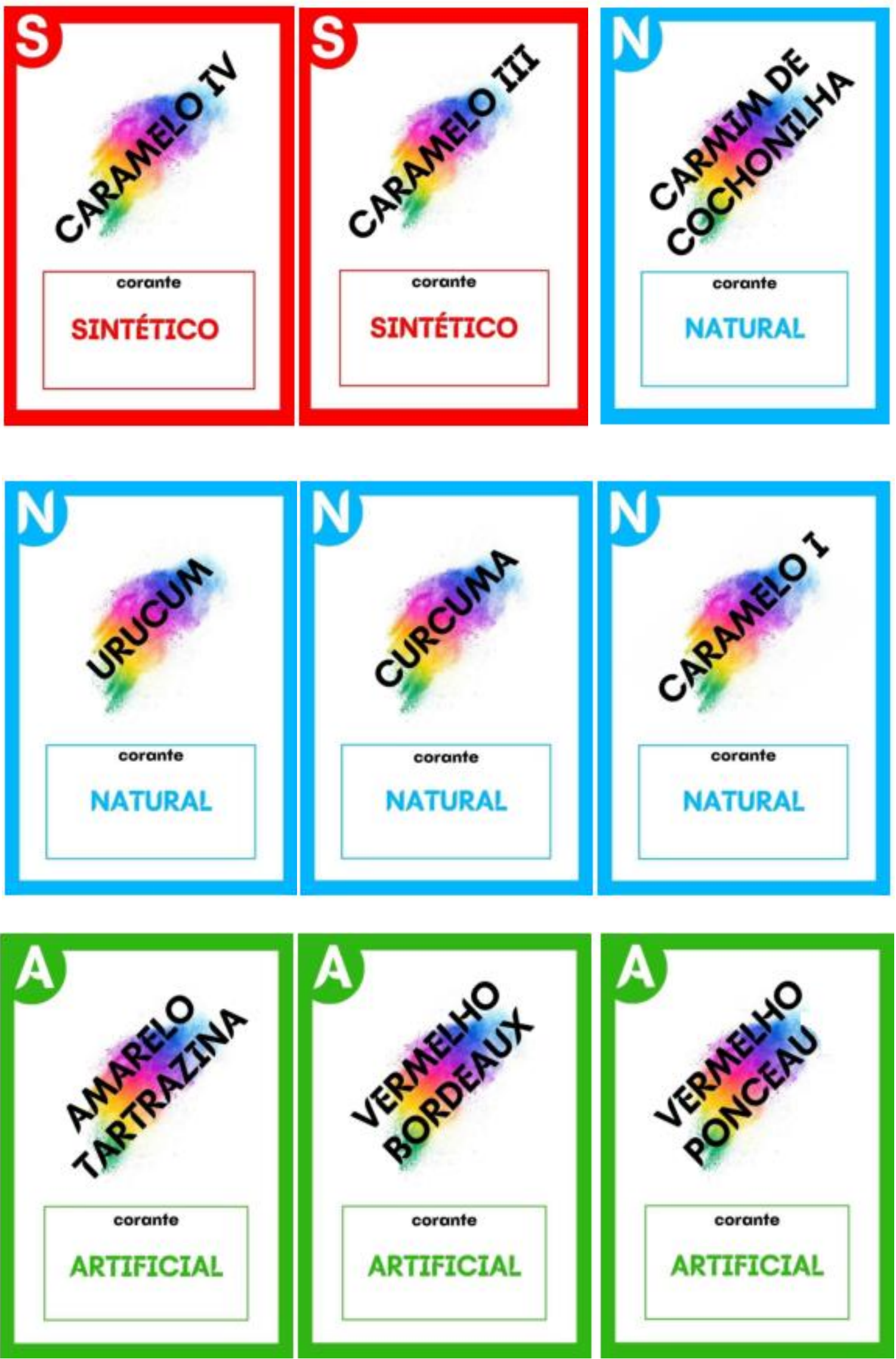

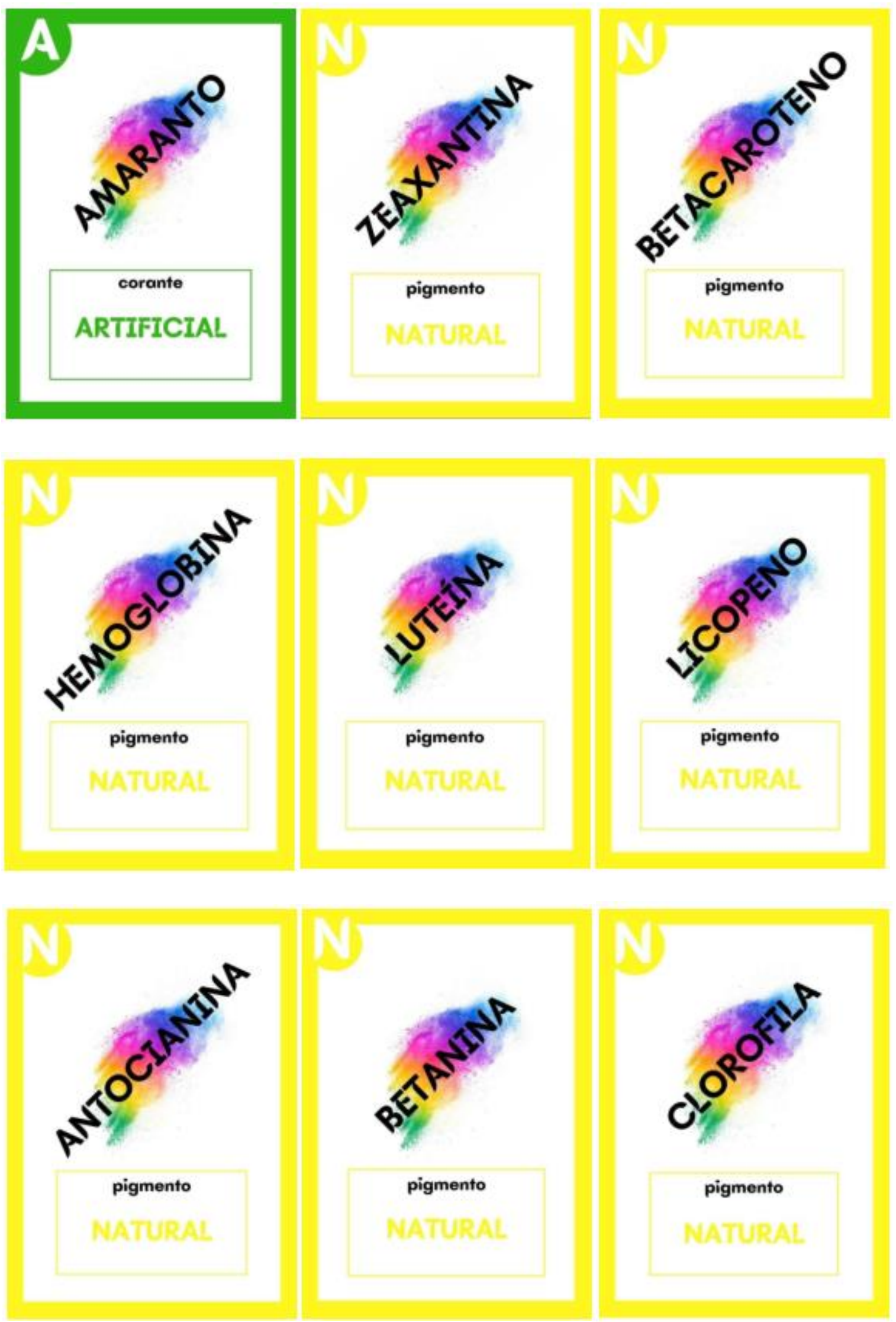


\section{CARTAS CATEGORIA III}
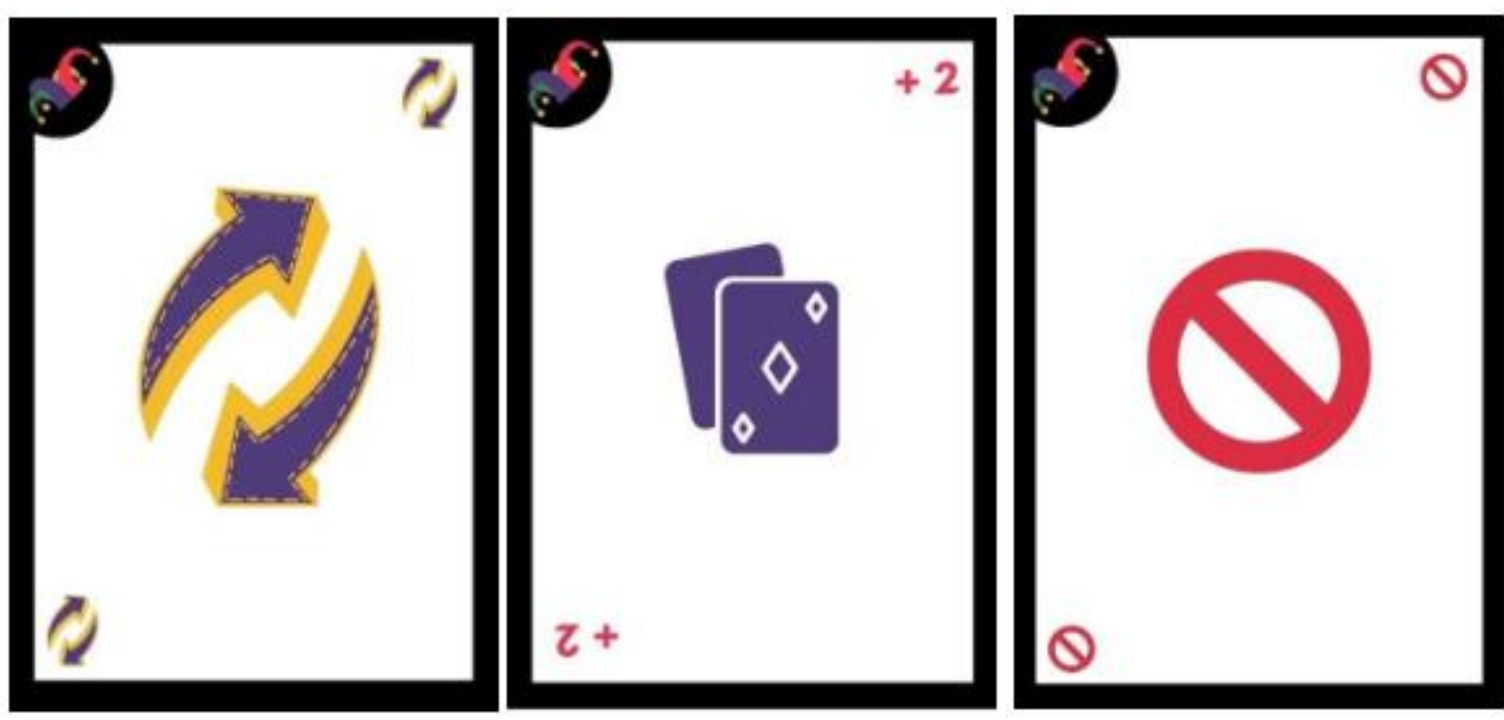

\section{CONCLUSÃO}

O jogo PigColor - Alimentos em Cores é visualmente chamativo e isso proporciona aos alunos um interesse maior em jogar e relacionar o conteúdo sobre Corantes e Pigmentos ministrado em sala de aula com os mais variados alimentos que contêm essas substâncias colorantes. Portanto, esse assunto é importante de ser abordado em contexto de ensino e aprendizagem por se utilizar um recurso didático lúdico. Além disso, é necessário que os alunos fiquem mais apropriados sobre esse assunto de pigmentos e corantes, pois os estudos demonstram que essas substâncias possuem efeitos maléficos e benéficos para a saúde humana, e há uma crescente procura por uma alimentação saudável pela população mundial.

\section{REFERÊNCIA}

[1] BRACH, Elizete Neuza. Uso do lúdico e da contextualização para aula de química orgânica. 2014. 42f. Trabalho de Monografia (Graduação em Educação) - Pós Graduação em Educação, Universidade Tecnológica Federal do Paraná, Curitiba, 2014.

[2] KIYA, Marcia Cristina da Silveira. Caderno Pedagógico: 0 uso de Jogos e de atividades lúdicas como recurso pedagógico facilitador da aprendizagem. Secretaria de Estado da Educação. Superintendência de Educação. Os Desafios da Escola Pública Paranaense na Perspectiva do Professor PDE: Produção Didáticopedagógica, 2014. Curitiba: SEED/PR., 2016. V.2. (Cadernos PDE). Disponível em: http://www.diaadiaeducacao.pr.gov.br/portals/cadernospde/pdebusca/producoes_pde /2014/2014_uepg_ped_pdp_marcia_cristina_da_silveira_kiya.pdf. Acesso em: 9 nov. 2020. ISBN 978-85-8015-079-7

[3] RÊGO, J. R. S.; JUNIOR, F. M. C.; ARAÚJO, M. G. S. Uso de jogos lúdicos no processo de ensino-aprendizagem nas aulas de Química. Estação Científica (UNIFAP), Macapá, ano 2017, v. 7, n. 2, p. 149-157, maio/agosto 2017. Disponível em: https://periodicos.unifap.br/index.php/estacao/article/view/2913. Acesso em: 9 nov. 2020. 


\section{Jogo 16}

\section{Jogo das Fichas}

Elane Cartaxo Nogueira

Eveliny Sombra Mota

Francisca Yhaskara Gomes da Silva

Patrícia Hellen da Silva Cavalcante

Maria Da Conceição Tavares Cavalcanti Liberato 


\section{INTRODUÇÃO}

Dentro ambiente escolar, os conteúdos de química aplicados, dependem das estratégias e recursos que são explorados pelos professores em aula para melhorar o aprendizado entre os alunos. Assim, o recurso utilizado deve ser familiar ao docente, pois pode provocar resistência e uma possível frustração entre os alunos se mal utilizado. (Hoberman, 1973). Segundo Silva (2014) uma possibilidade para o ensino do conteúdo é a dinamização dos recursos empregados para maior diversidade nas aulas. Ainda segundo Silva (2014) o uso de jogos em sala de aula ajuda em vários aspectos como a fixação da matéria, no crescimento pessoal do aluno, já que promove a interação social dele construindo uma experiência com o jogo favorecendo o conhecimento.

\section{MATERIAIS}

1. Fichas com as perguntas sobre o tema temperos (industrializados/ naturais). Perguntas:

- O que são temperos?

- Diga um benefício dos temperos industrializados?

- O que são temperos industrializados?

- Sobre os temperos industrializados qual o mal pode causar a saúde do ser humano?

- 5 -Cite quatro temperos naturais.

- Quais os benefícios ao se utilizar os temperos naturais?

- Qual a função dos conservantes?

- Porque se deve ler o rótulo antes de comprar qualquer produto?

- Cite 4 alimentos que o glutamato está presente.

- Qual a função do espessante?

\section{MÉTODO}

1. A professora devera organizar os alunos em duas equipes;

2. Depois de separar as esquipes a professora terá de escolher um aluno de cada equipe para que ele escolha um número de 0 a 10 ;

3. Após cada aluno ter escolhido a sua ficha a professora irá direcionar ao mesmo a pergunta sorteada e se o aluno acertar a pergunta a equipe acumulará pontos, e assim sucessivamente vai escolhendo outros alunos até a última pergunta e no final a equipe que obtiver mais pontos vencera a competição.

\section{OBJETIVO}

Fazer com que alunos obtenha conhecimentos sobre os temperos de ambas formas naturais e industrializados, e os que eles podem trazer de benefícios ou malefícios. 


\section{REFERÊNCIAS}

[1] Hoberman, A. M. (1973) Como realizam as mudanças em educação: subsídios para o estudo da inovação. São Paulo: Cultrix

[2] SILVA, Rafael Branco da. Aprender Brincando: 0 ensino da química através de jogos. 2014. 44 f. Monografia (Especialização) - Curso de Especialização em Fundamentos da Educação: Práticas Pedagógicas Interdisciplinares da Universidade Estadual da Paraíba, Universidade Estadual da Paraíba, Princesa Isabel - Pb, 2014. Disponível em:

http://dspace.bc.uepb.edu.br/jspui/bitstream/123456789/6653/1/PDF\%20\%20Rafael\%20Branco\%20da\%20Silva.pdf. Acesso em: 27 mar. 2021. 


\section{Jogo 17}

\section{Dominó de corantes e pigmentos em libras}

Gustavo Henrique Gomes Teixeira

José Augusto Fernandes de Meneses

Maria da Conceição Tavares Cavalcanti Liberato 


\section{INTRODUÇÃO}

0 fato de a inclusão escolar ser atualmente um assunto muito discutido principalmente no âmbito escolar não significa que as pessoas que debatem este assunto entendam a inclusão da mesma maneira, pois muita pessoa tem uma visão de inclusão muito distorcida. De fato este (o surdo) se encontra em uma sociedade que se comunica de forma diferente, mas isso não deveria limitá-lo de seus objetivos, e isso dá espaço para uma discussão sobre o que é inclusão e o que é integração, pois de certa em muitos ambientes e por mais inacreditável que pareça até em âmbito escolar os surdos tem apenas sido integrados.

Para a implementação da escola inclusiva, inicialmente, exige-se a mudança de mentalidade e a construção de um novo paradigma educacional uma forma que se possa incluir todos no meio do ensino e que possam participar ativamente.

\section{METODOLOGIA}

№ de jogadores: 2

O jogo possui 16 peças, assim como o jogo tradicional, cada peça é constituída de por dois lados, um lado representa uma cor e do outro representa o nome do corante ou pigmento. Cada cor deve ser associada a nome do respectivo corante/pigmento que possui aquela cor característica. Exemplo: Clorofila $\rightarrow$ Verde

0 jogo é realizado com 2 jogadores por vez, onde cada um fica com 8 peças. Ganha o jogo aquele que primeiro conseguir associar todas as suas peças ao seu respectivo par. As peças possuem tanto a datilografia ou sinal do nome de cada pigmento/corante e cor, como também apresenta seu nome na língua portuguesa. No caso das cores pode-se identificar também através da cor presente na peça.

Para realização do jogo, deve-se ter um prévio conhecimento do conteúdo de Corantes e Pigmentos. 


\section{ANEXO}

Figura 1: Cartas do jogo
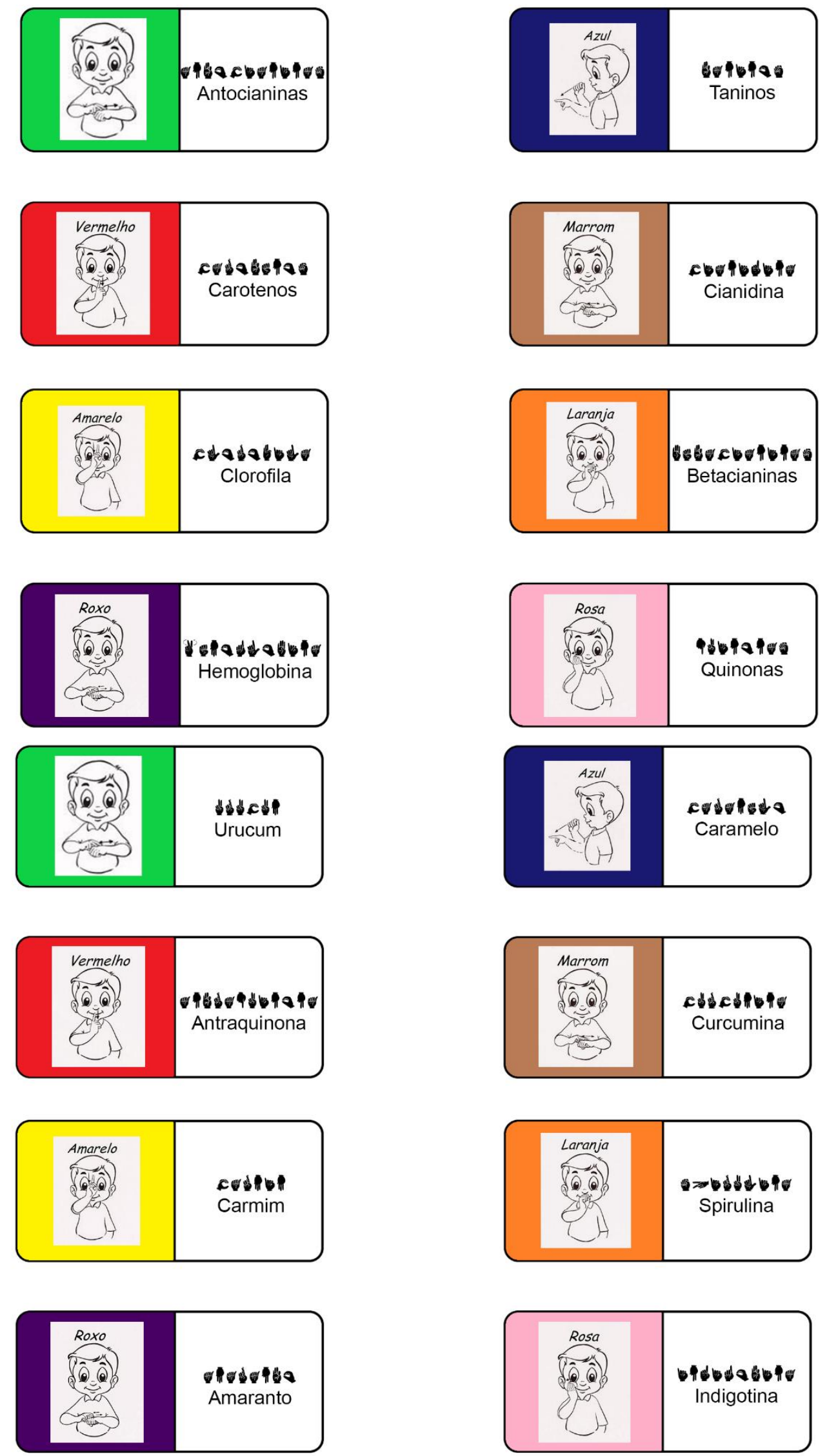


\section{REFERÊNCIAS}

[1] BAPTISTA, C. R. (2009). Educação especial e o medo do outro: attento ai segnalati!. Em: C. R. Baptista (Org.). Inclusão e escolarização: múltiplas perspectivas (pp. 17- 29). Porto Alegre: Mediação.

[2] Cardona González, S., Díaz Gómez, A., García García, L. M., Mejía Botero, L., Morales Parra, J., Rivera Franco, J. E., y Valencia González, G. C. (2011). Educación y sociedad. Argentina: Clacso

[3] Geosaberes, EDUCAÇÃo PARA TRANSFORMAR AS PESSOAS DO MUNDO, GEOGRAFIA PARA MUDAR O MUNDO DAS PESSOAS: APROXIMAÇÕES TEORICAS ENTRE PAULO FREIRE E MILTON SANTOS, 2010. Disponível em: DialnetEducacaoParaTransformarAsPessoasDoMundoGeografiaPa-6096759.pdf. Acesso em: 28 jan. 2021.

[4] LIBERATO, M. C. T. C. Química dos alimentos Estruturas, Propriedades e Transformações. 1a. ed. Belo Horizonte - MG: Editora Poisson, 2020. v. 1. 87p .

[5] MANTOAN, M. T. E. (1997) A Inclusão Escolar de Deficientes Mentais: contribuições para o Debate. In. Revista Integração, Brasília, ano 7, n. 19, p. 50-57.

[6] Salazar, Gioser. Maracay, 2016. Integración vs. Inclusión educativa de los estudiantes con discapacidad auditiva: una mirada desde el bilingüismo del sordo. Disponível em: https://cultura-sorda.org/integracion-vs-inclusion-educativa-de-losestudiantes-con-discapacidad-auditiva-una-mirada-desde-el-bilinguismo-del-sordo.

Acesso em: 28 jan. 2021. 


\section{Jogo 18}

\section{Three Clues}

Dayanne Cipriano Costa da Silva

Maria da Conceição Tavares Cavalcanti Liberato 


\section{INTRODUÇÃO}

Os corantes são historicamente utilizados como recurso de melhoramento visual do alimento. Desde da antiga civilização egípcia até os dias de hoje podemos observar a importância da cor dos alimentos. Com o avanço da ciência, foi possível a extração de variados corantes naturais, como também, a sintetização dos artificias. A utilização dos corantes em alimentos acompanhou linearmente o crescimento industrial, contudo, as polêmicas em volta da sua utilização também. Tal problemática transcende o meio empresarial sendo colocado como pauta de debate nas aulas de química. Em sala, o professor tenta estimular o conhecimento sobre os corantes, mostrando a química e outros demais aspectos (extração, meio ambiente, saúde, aplicações) que o circundam. Afim de tornar o assunto mais atraente e otimizar o aprendizado deste conteúdo, o jogo vem como um método válido de: proporcionar ao indivíduo uma oportunidade a mais de se abastecer de informações, baseando-se em simulações e fantasias que ele executa (BROUGERE, 1998).

Objetivo:_Identificação dos corantes, e suas aplicações.

Número de jogadores: De 2 a 8 pessoas.

\section{MATERIAIS E MÉTODOS}

Castro e Costa (2011) fala que, a principal dificuldade atualmente para o ensino de química é fazer conexões entre o conteúdo dado em sala e o cotidiano dos alunos. Cleophas, Cavalcanti e Soares (2018) afirmam que todos os jogos tem como objetivo algum fim educativo. Pensado em promover um meio facilitado do aprendizado sobre: corantes, suas características e aplicações foi desenvolvido o jogo 13 CLUES, este tem como inspiração os jogos populares de perguntas e resposta com o MASTER GROW (fabricado pela marca GROW,empresa de entretenimento).0 jogo vem como um auxílio para melhor fixação do conteúdo, uma vez que, estimula ao aluno a desenvolver um pensamento sistemático e associativo com o conteúdo abordado em sala.

\section{Estrutura do jogo:}

O jogo conta com 4 pinos (amarelo, verde, preto e azul),16 cartas de dicas, e um tabuleiro.

\section{Guia do jogo:}

0.1 No tabuleiro 01, o jogador escolhe um número de 01 a 16.

0.20 número correspondente representara sua ficha.

0.3 Usando as informações da ficha, o jogador tentara através de mimica ou desenhos sinalizar as três palavras contidas na ficha.

Observação: Para cada palavra o tempo limite é UM MINUTO.

- Cada palavra possui uma pontuação diferente variando de 01 a 03.

(Ao final do tempo os valores devem ser somados, e o resultado será a quantidade de casas que se deve avançar).

- Utilizando o tabuleiro 02, as equipes devem marcar seu avanço.

- Aconselhável se utilizar: folhas de papel oficio ou lousa. 
- Modelo das fichas.

Figura1: Modelos de fichas

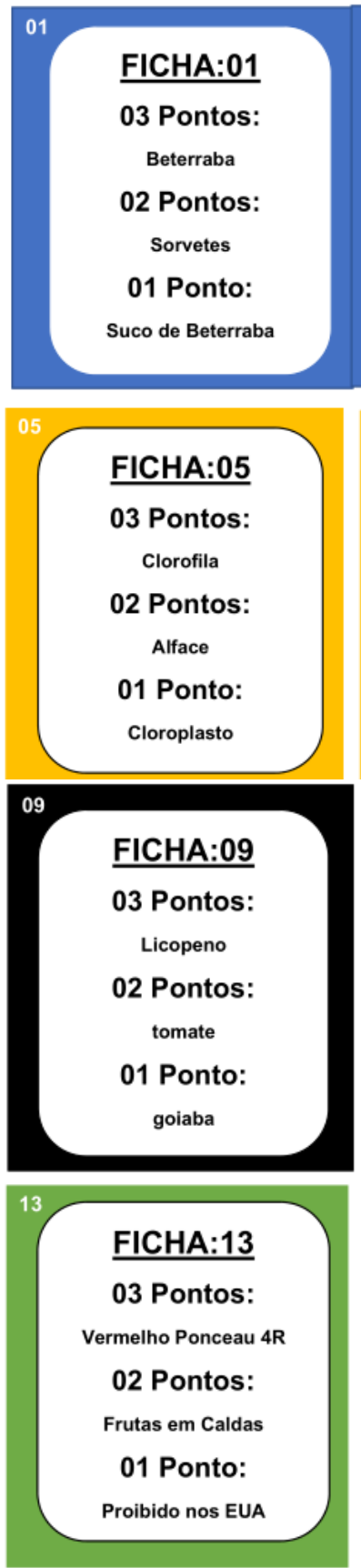

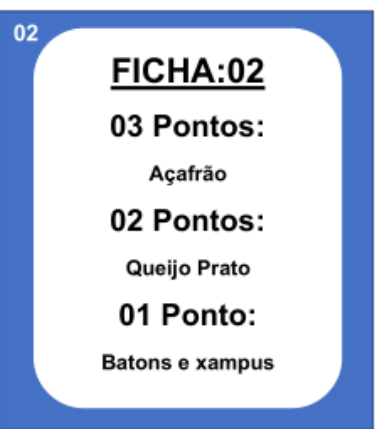
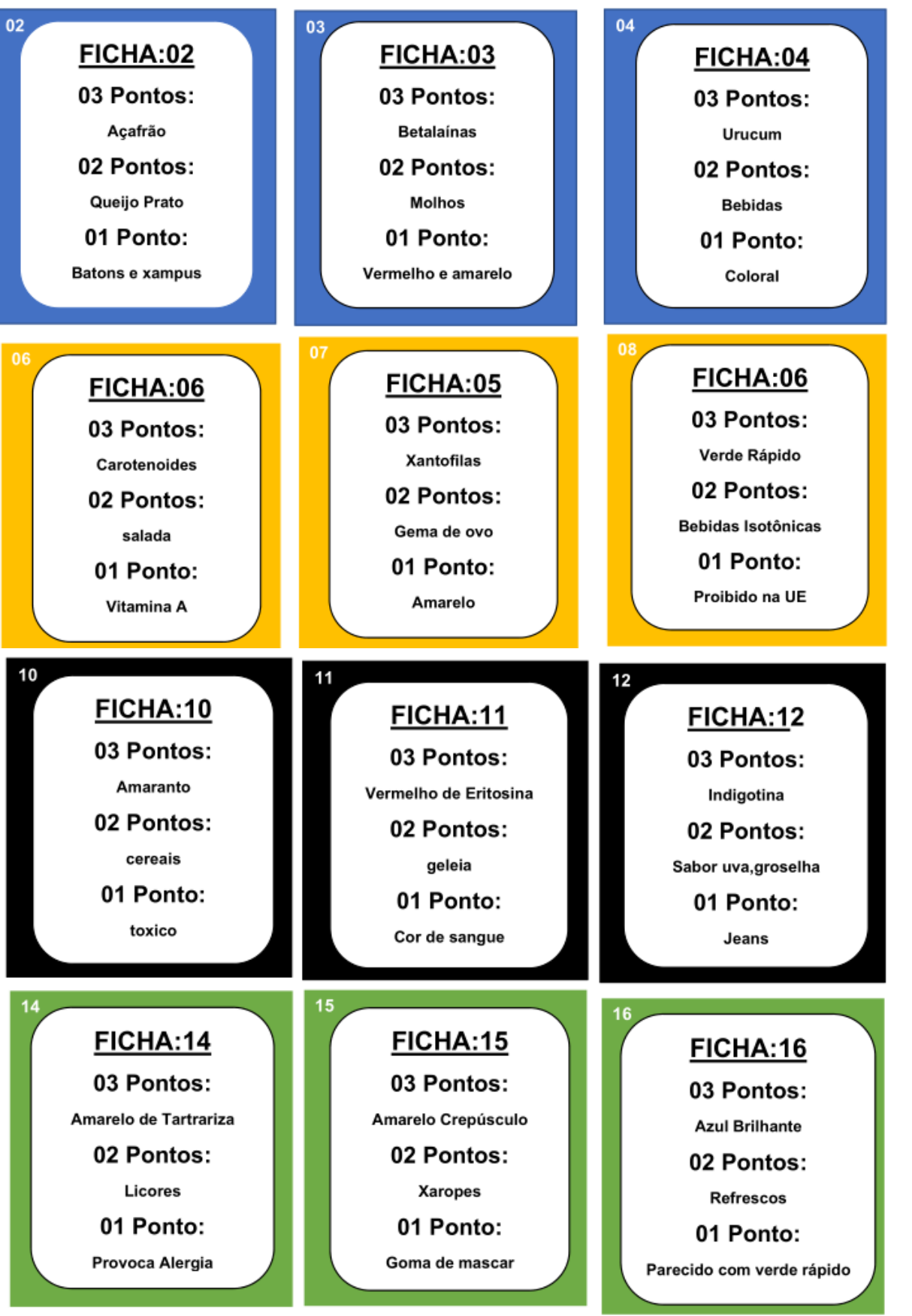

Fonte Autores 
- Números das fichas.

Figura 4: Cartas
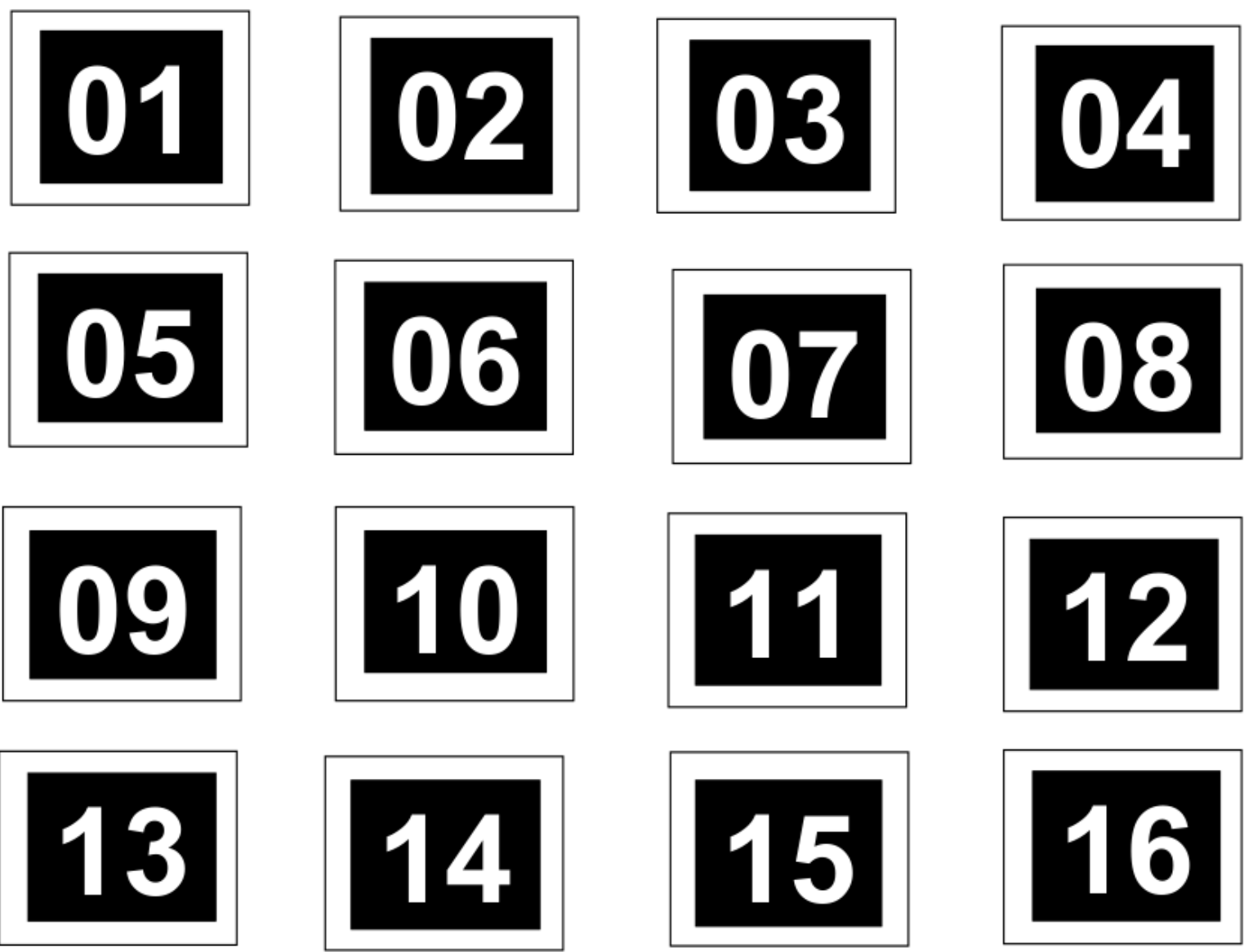

Fonte Autores 
- Pinos para o Jogo

Figura 3: Anexo pinos Fonte Autores

PINO AMARELO

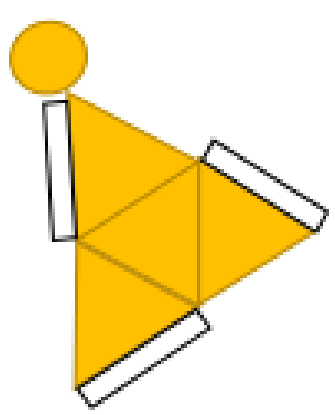

PINO AZUL

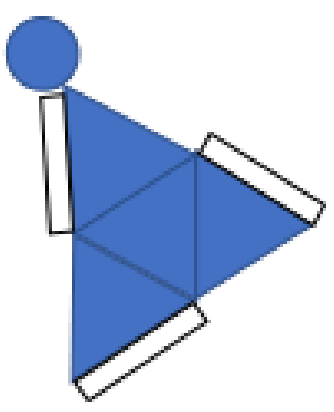

PINO PRETO

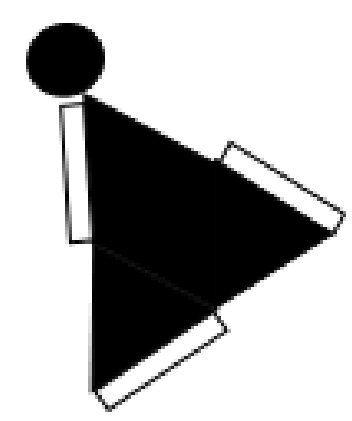

PINO VERDE

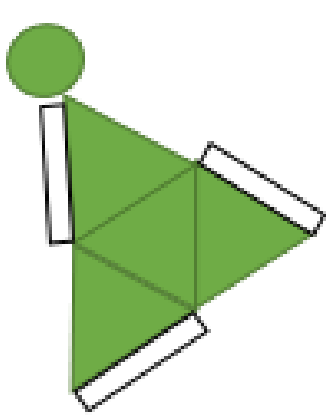


Tabuleiro

Figura 4: Tabuleiro

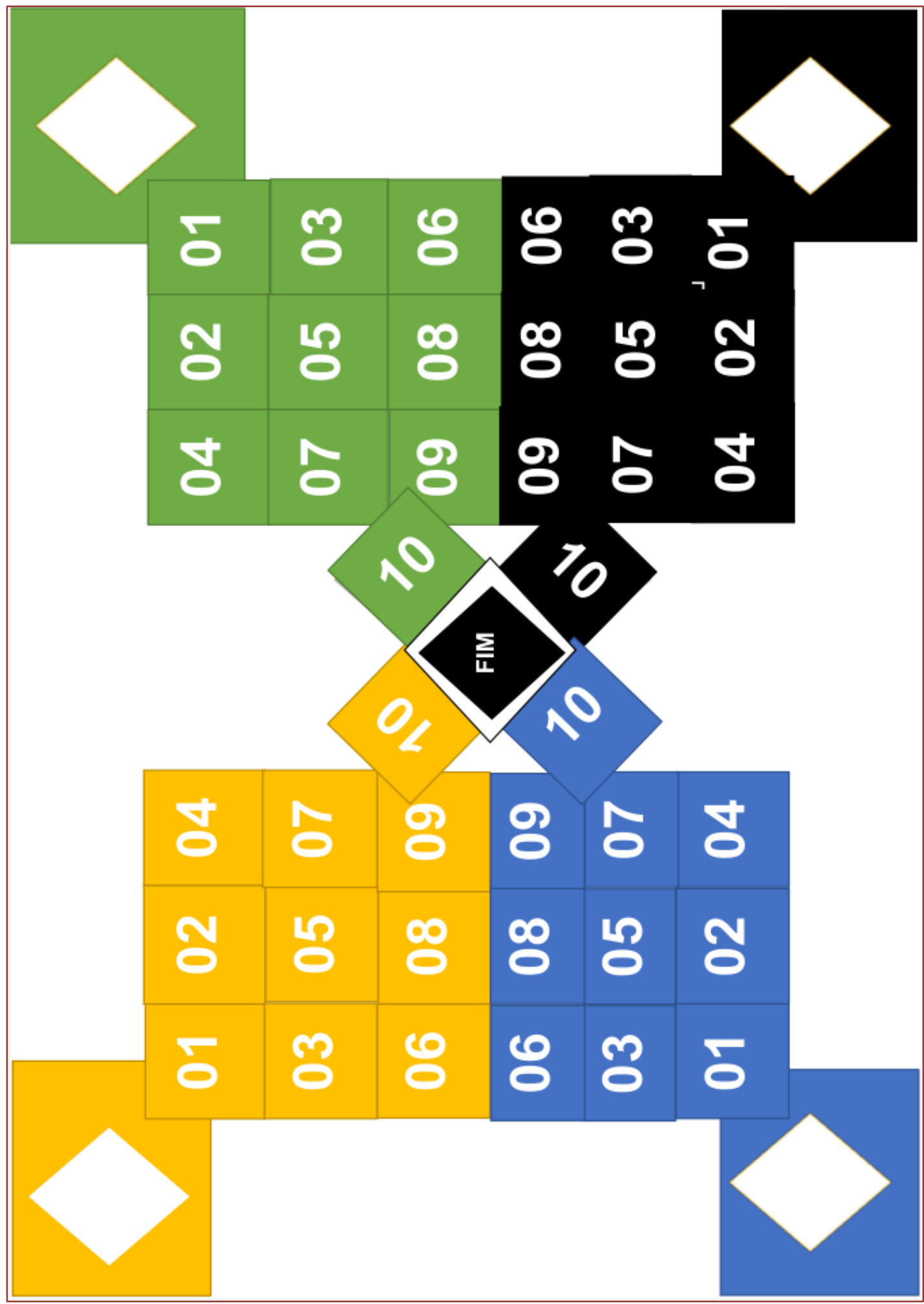




\section{REFERÊNCIAS}

[1] BRougere, G. O Jogo e a Educação. Porto Alegre: Art Med Editora, 1998.

[2] CASTRO, B. J.; COSTA, P. C. F. Contribuições de um jogo didático para o processo de ensino e aprendizagem de Química no Ensino Fundamental segundo o contexto da Aprendizagem Significativa. Revista Electrónica de Investigación en Educación en Ciencias, vol. 6, n. 2, 2011.

[3] Cleophas, M. das G., Cavalcanti, E. L. D., \& Soares, M. H. F. B. (2018). Afinal de contas, é jogo educativo, didático ou pedagógico no ensino de Química/Ciências? Colocando os pingos nos "is". In M. das G., Cleophas, \& M. H. F. B. Soares (Org.), Didatização Lúdica no Ensino de Química/Ciências (pp. 33-62). São Paulo, SP: Livraria da Física.

[4] NETTO, R. C. M. Dossiê corantes. FOOD INGREDIENTS BRASIL, n. 9, 2009. Disponível em: . Acesso em: 13 de.sept.2020 .

[5] POLONI, R.; LUCA, M. Corantes naturais frentes às tendências mundiais. Periódico Tchê Química, v. 4, n. 7, p. 33-40, Porto Alegre, 2007. Disponível em:<http://www.deboni.he.com.br/tq/revista/revista7.htm> Acesso em: 13 de.sept.2020 .

[6] SOUZA, R. M. CORANTES NATURAIS ALIMENTÍCIOS E SEUS BENEFícios À SAÚDE. 2012. Monografia (Graduação Farmácia), Centro Universitário Estadual da Zona Oeste, Rio de Janeiro, 2012. Orientador: Professor Marco Antônio Mota e Professora Sabrina da Silva Dias.

[7] VEloso, L. A. Corantes e Pigmentos - Dossiê Técnico. Serviço Brasileiro de Respostas Técnicas. Instituto de Tecnologia do Paraná, 2012. 


\section{Jogo 19}

\section{Jogo de Cartas \\ Corantes e Pigmentos}

Alisson Marley Rodrigues Alcantara

Chrislane Barbosa de Sousa

Álvaro Ventorini Vasconcelos

Geovana Costa Aguiar

Maria da Conceição Tavares Cavalcanti Liberato 


\section{INTRODUÇÃO}

Segundo Rocha e Vasconcelos (2016) há um grande desânimo por parte dos alunos no atual ensino de química devido as metodologias tradicionais que aumentam as dificuldades desses alunos no processo de aprendizagem e de associa-las ao cotidiano onde vivem. A introdução de jogos nas metodologias das aulas de química permite que os estudantes tenham experiências tanto no campo do conhecimento quanto em outros campos como o afetivo e o social. (Cunha, 2012).

Esse jogo tem como objetivo central aumentar o interesse dos alunos sobre os corantes e pigmentos de maneira lúdica e divertida para que seja usado durante as aulas de química do ensino médio a faculdade.

\section{MATERIAIS E MÉTODOS}

O Jogo contém:

- 46 cartas no baralho.

- Cores: Amarelo, Vermelho, azul e Verde.

Amarelo: cartas de 0 a 6.

Vermelho: Cartas de 0 a 6.

Azul: Cartas de 0 a 6.

Verde: cartas de 0 á 6

- Carta coringa (puxe +4 cartas) (4 cartas)

- Carta colorida (4 cartas)

- Carta bomba relógio (8 cartas)

\section{Regras}

- Carta 0, o jogador pode trocar o baralho, se quiser, com outro jogador da mesa.

- Carta colorida muda a cor da rodada

- Carta bomba relógio, o jogador terá 1 minuto para responder uma pergunta, caso não acerte a pergunta no tempo certo, ficará uma rodada sem jogar.

\section{Bomba relógio}

- Cite um alimento que possui o corante ou pigmento que corresponde a cor da rodada.

- Cite 2 pigmentos naturais.

- Cite um risco que os corantes artificiais podem causar a saúde.

- Cite 2 benefícios contidos nos alimentos com a pigmentação amarelo ou vermelho.

- A clorofila refere-se a que pigmento? R (Verde)

- Os carotenoides estão presentes em que alimentos? (alimentos com cores laranja, vermelha e amarelas).

- 1 alimento que possua o corante vermelho 40.

- Qual a maior utilidade dos corantes?

*Obs: 0 jogo possui o sistema de Identificação de cores para pessoas daltônicas, o Color Add. Desenvolvido por Miguel Neiva, Designer Gráfico português e professor da Universidade do Minho. 

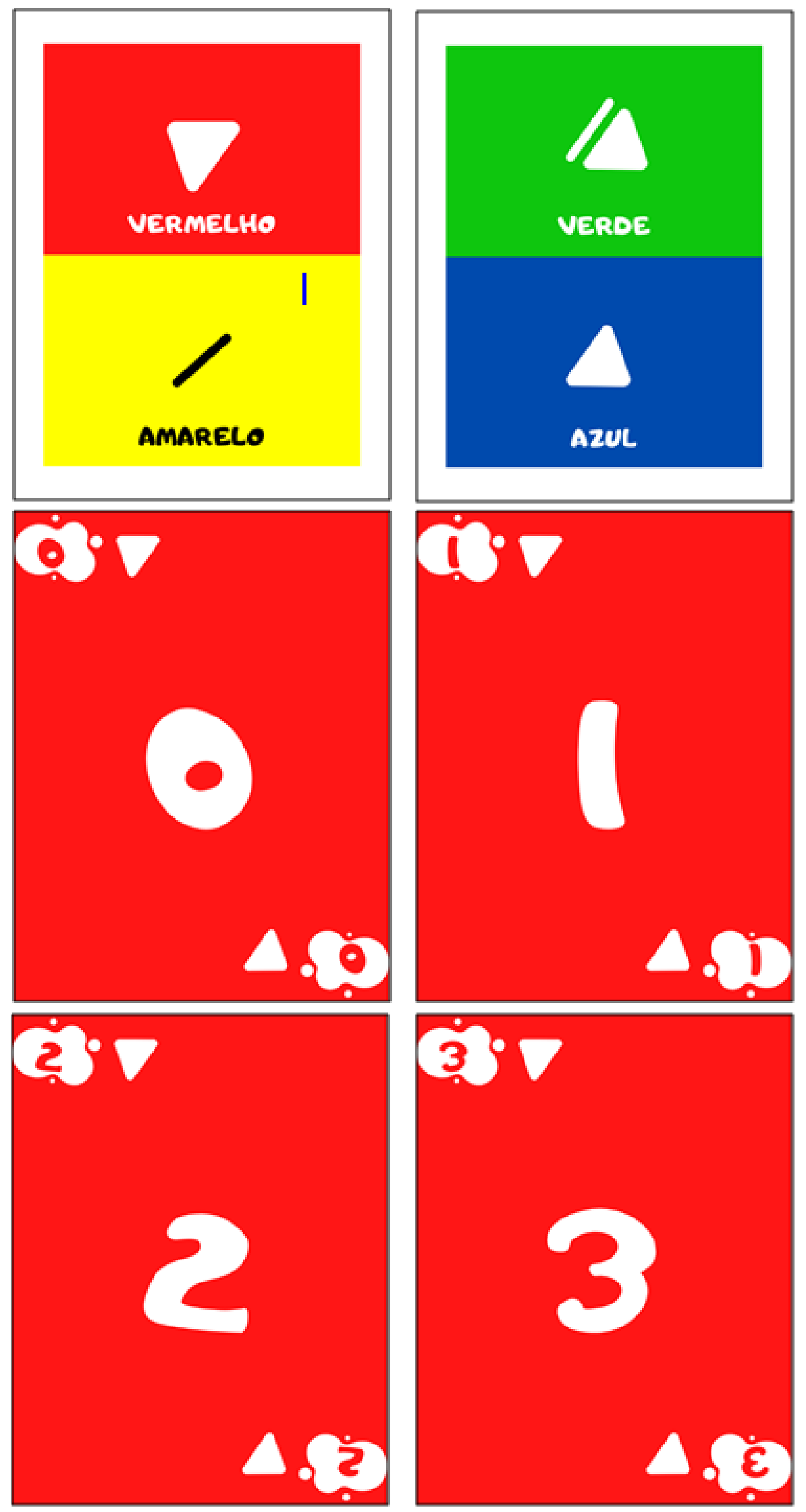

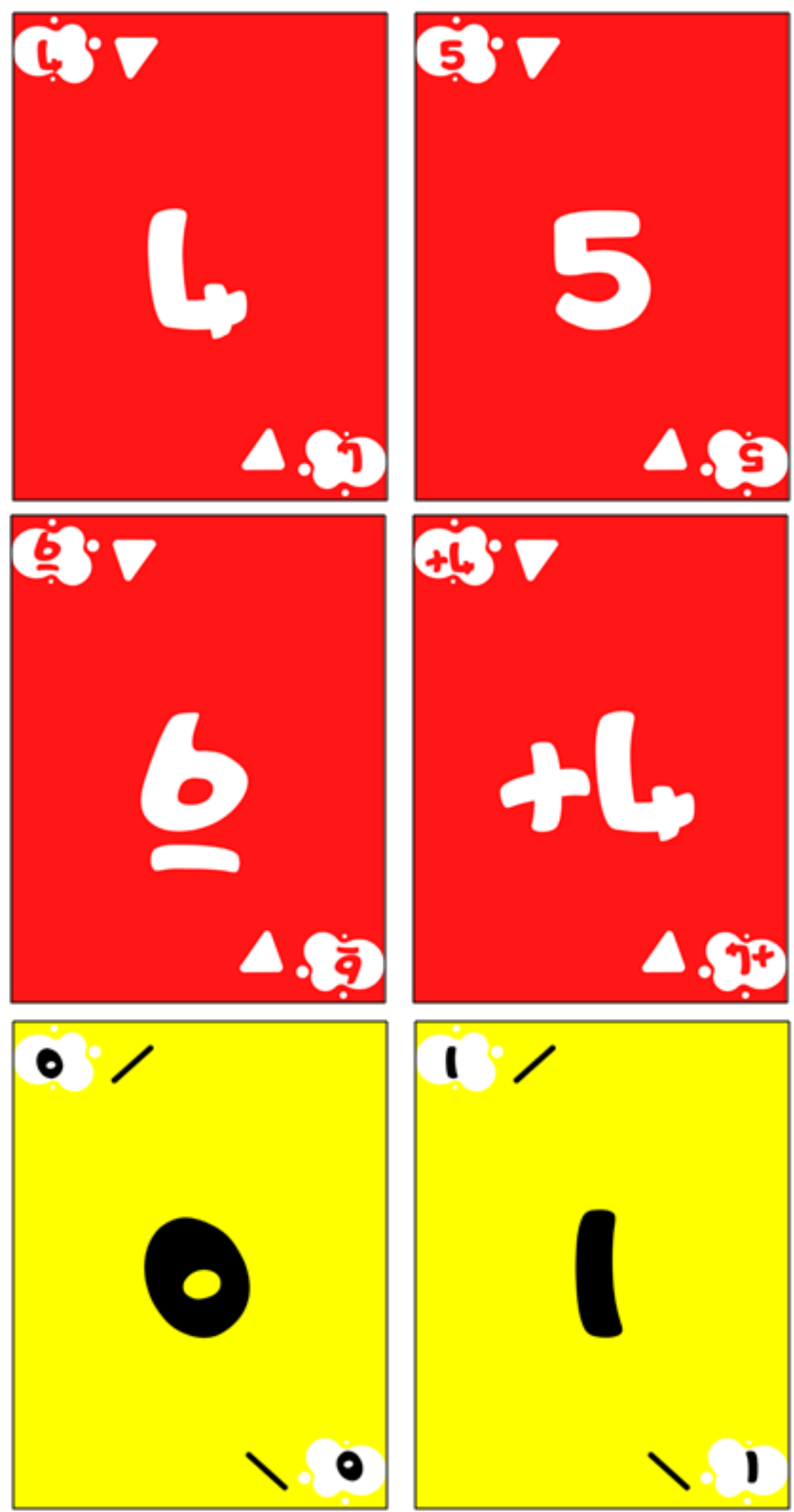

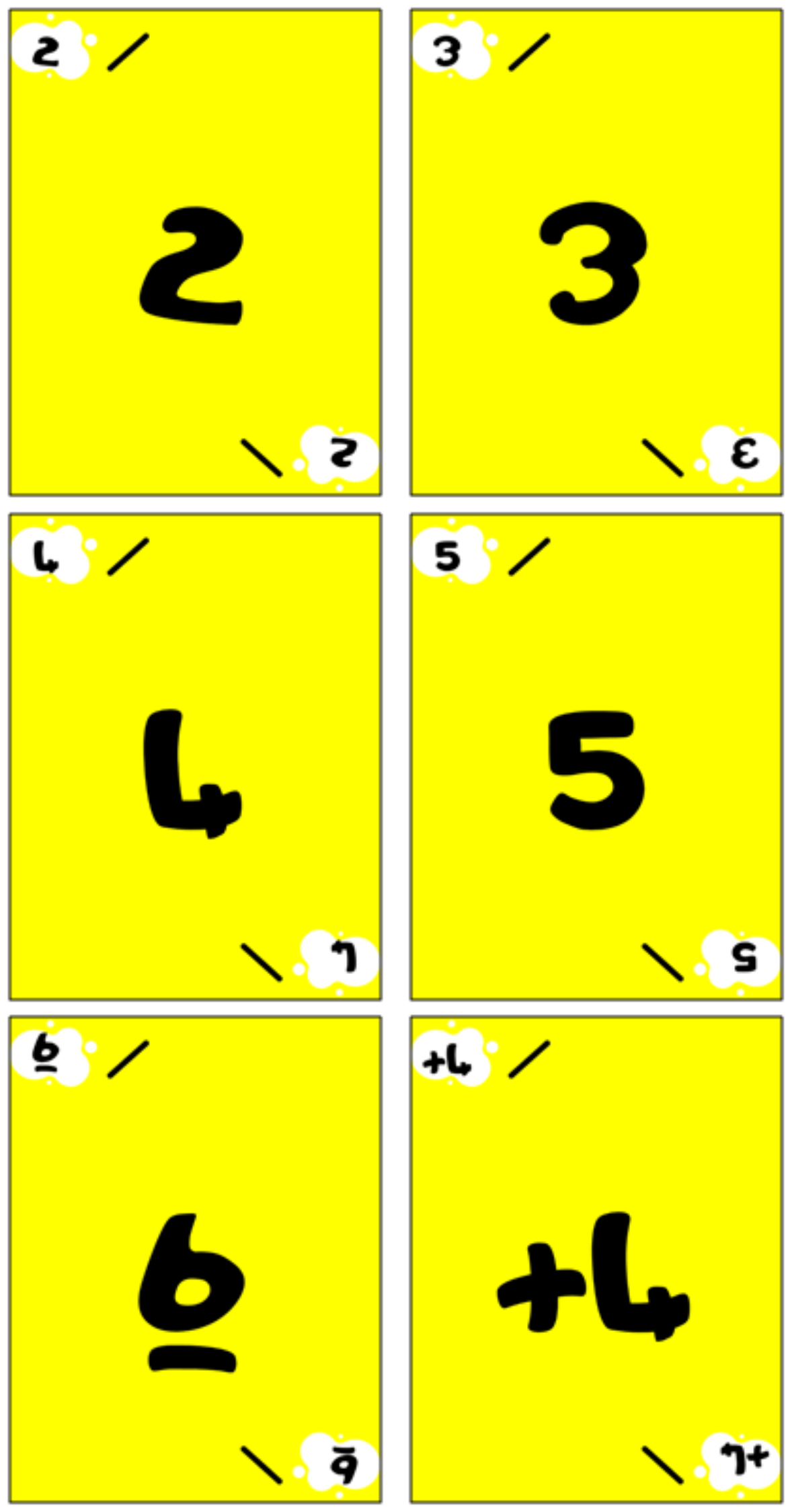

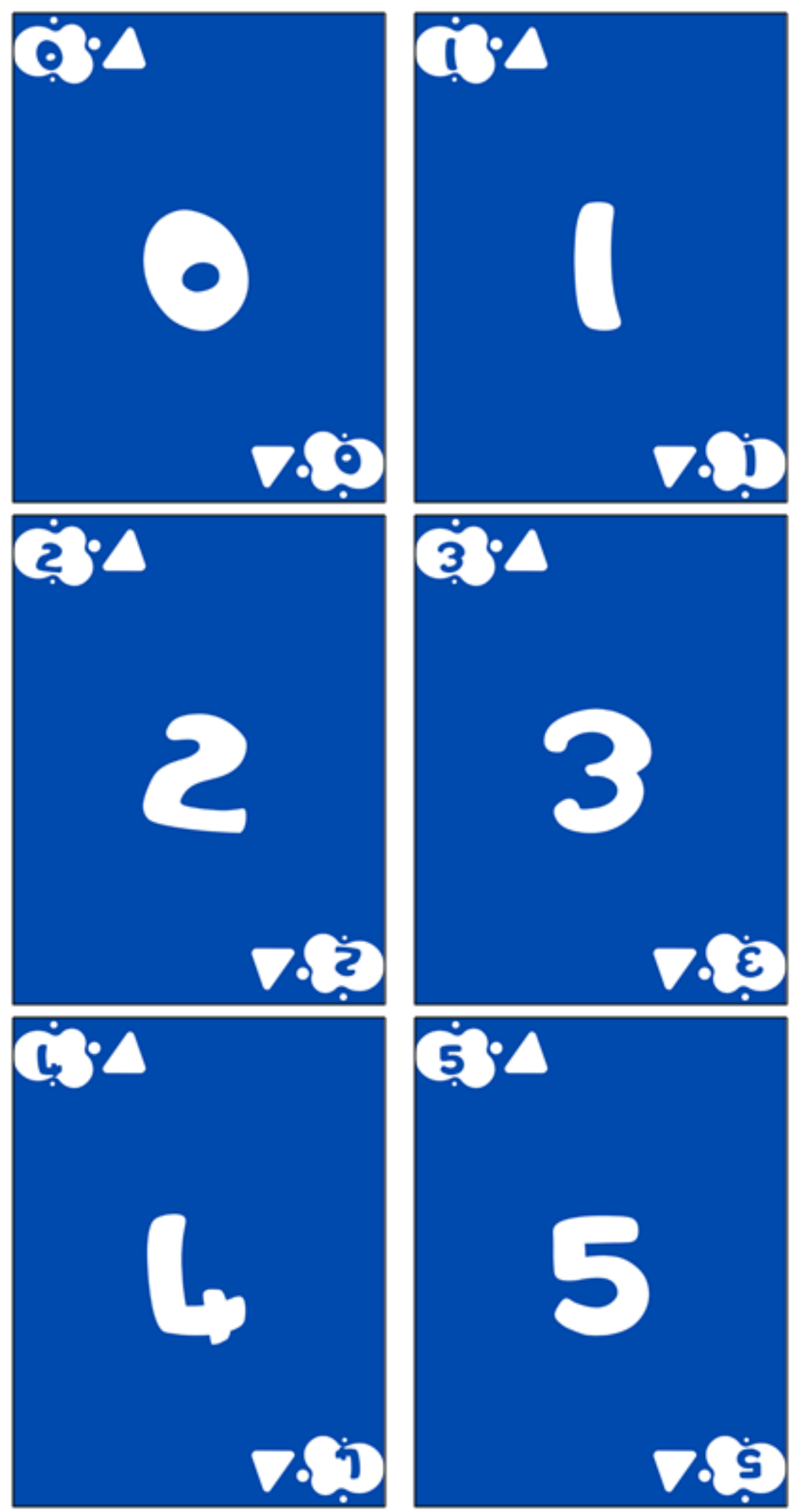


\section{6ำ}
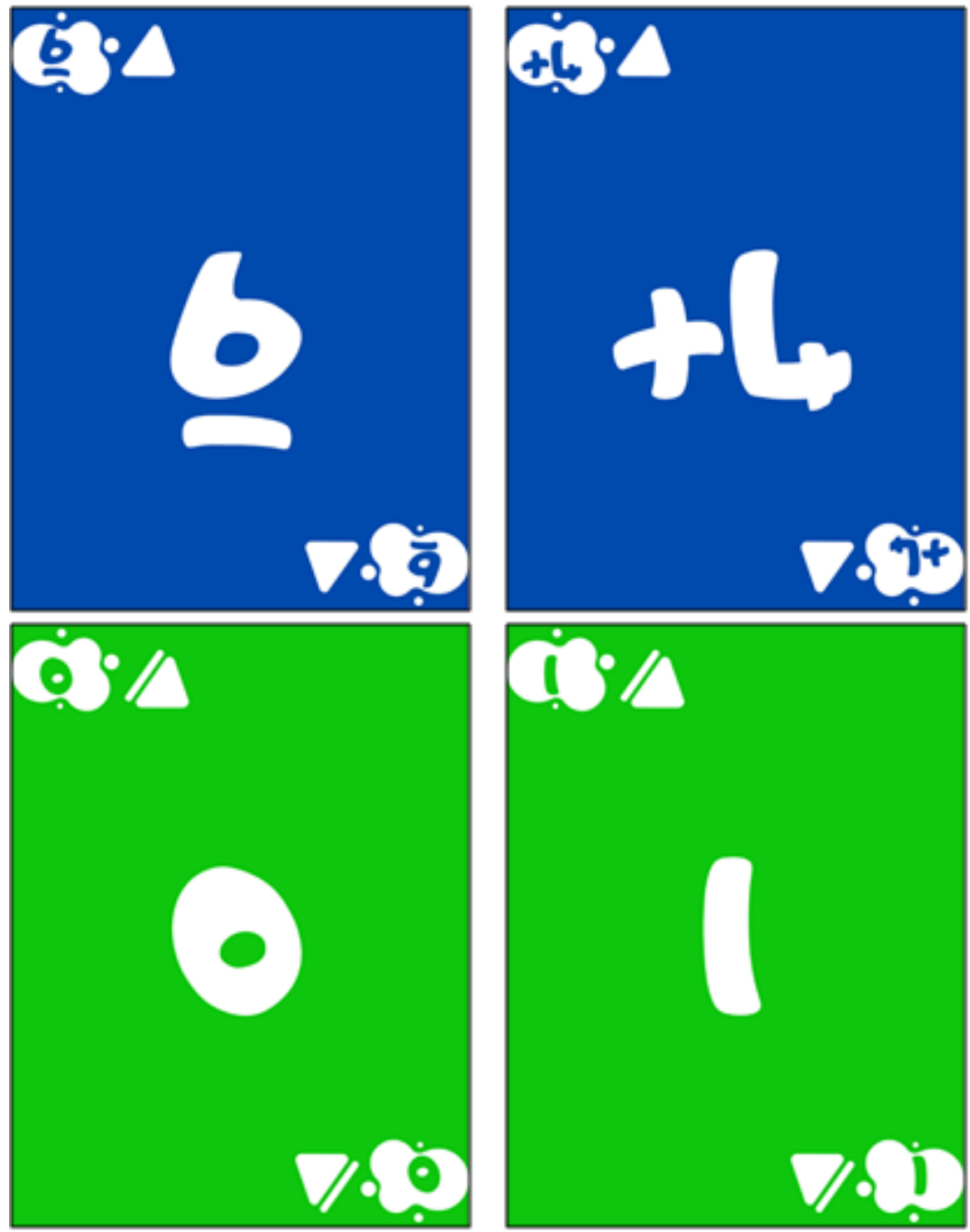

क्र 1
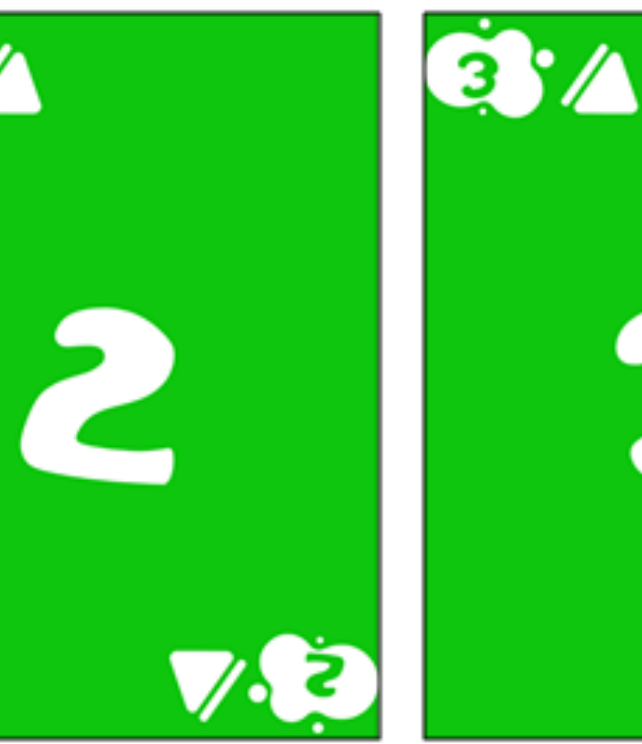

$\nabla$ เ 

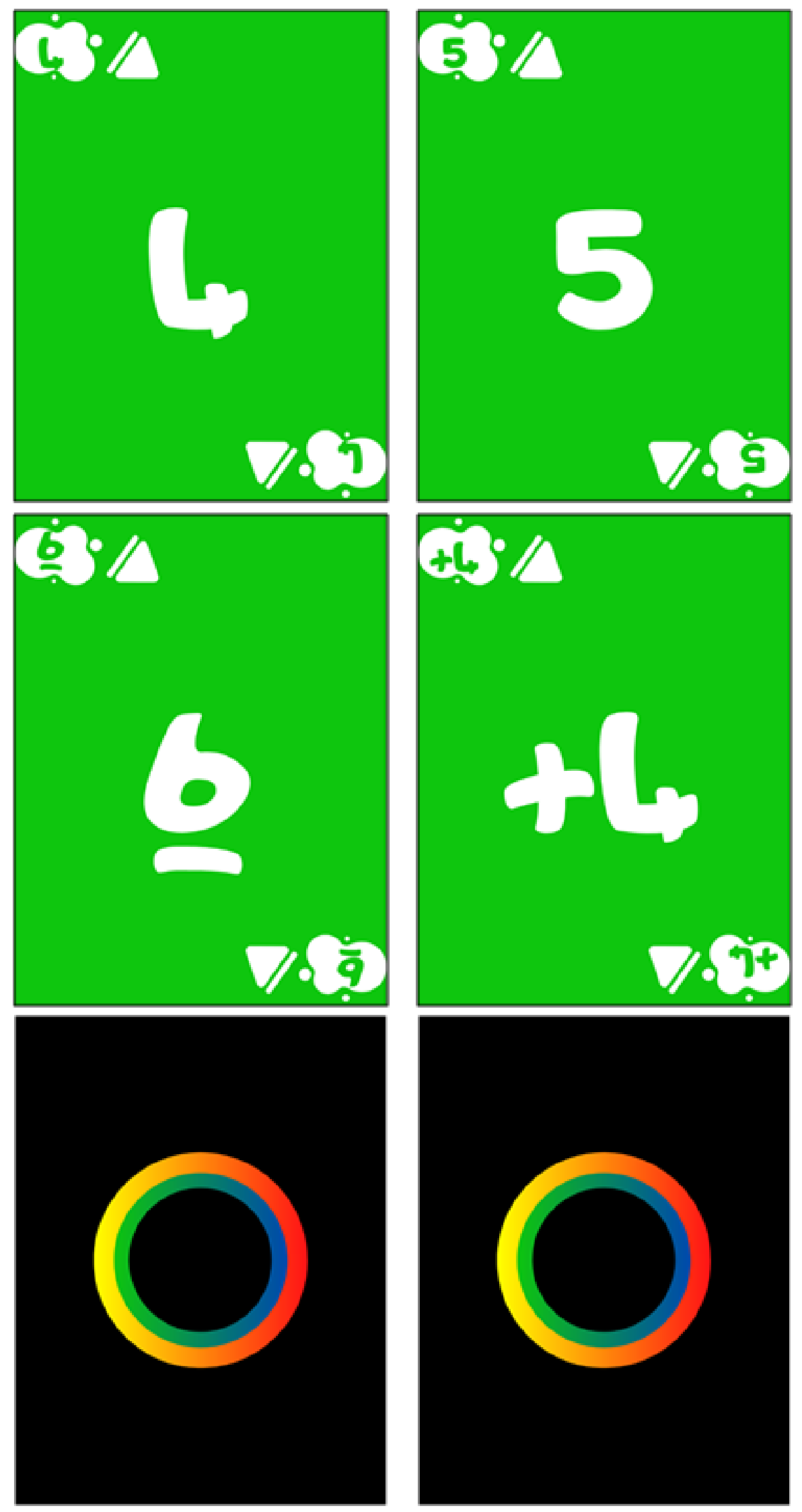

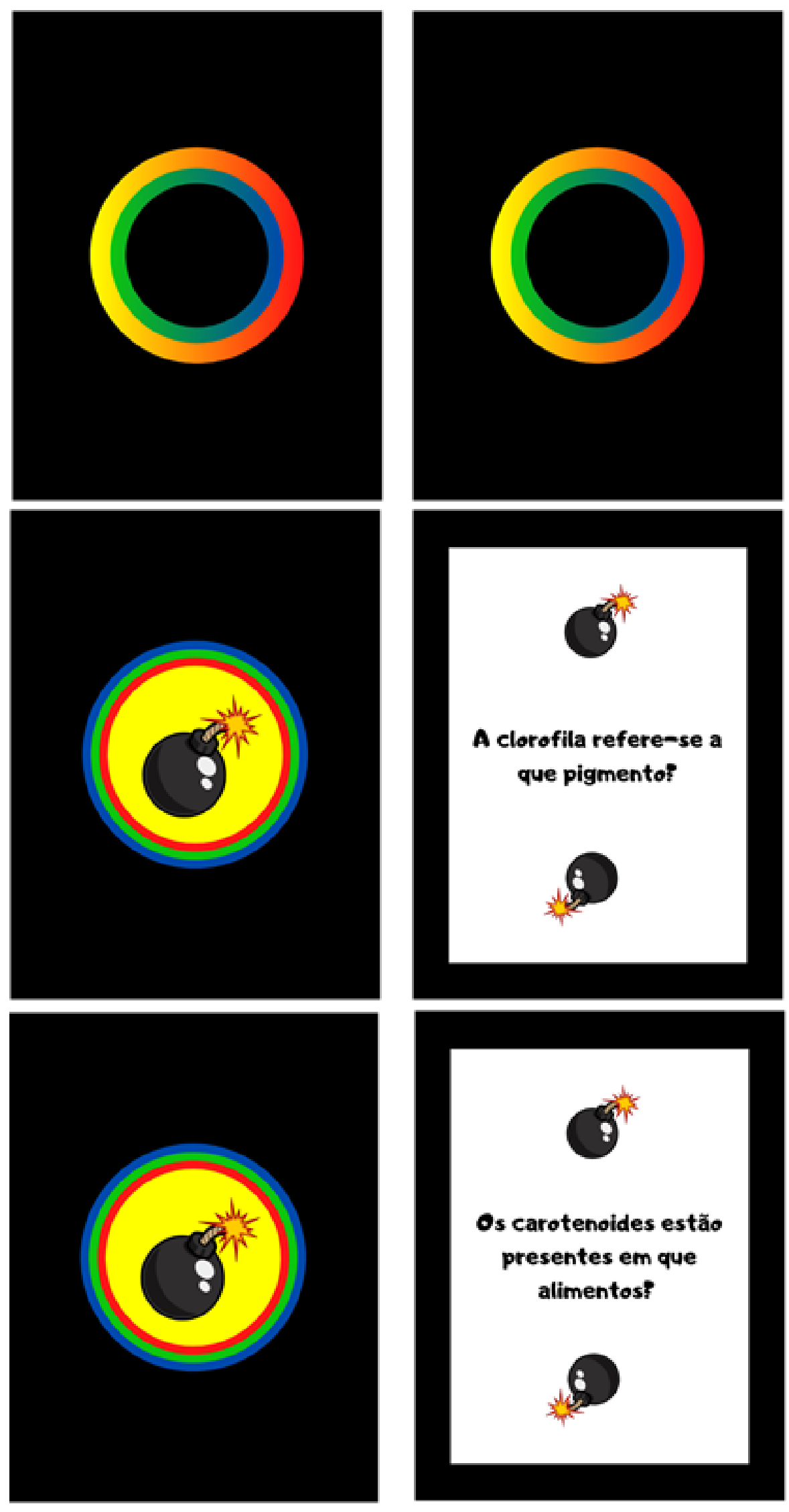

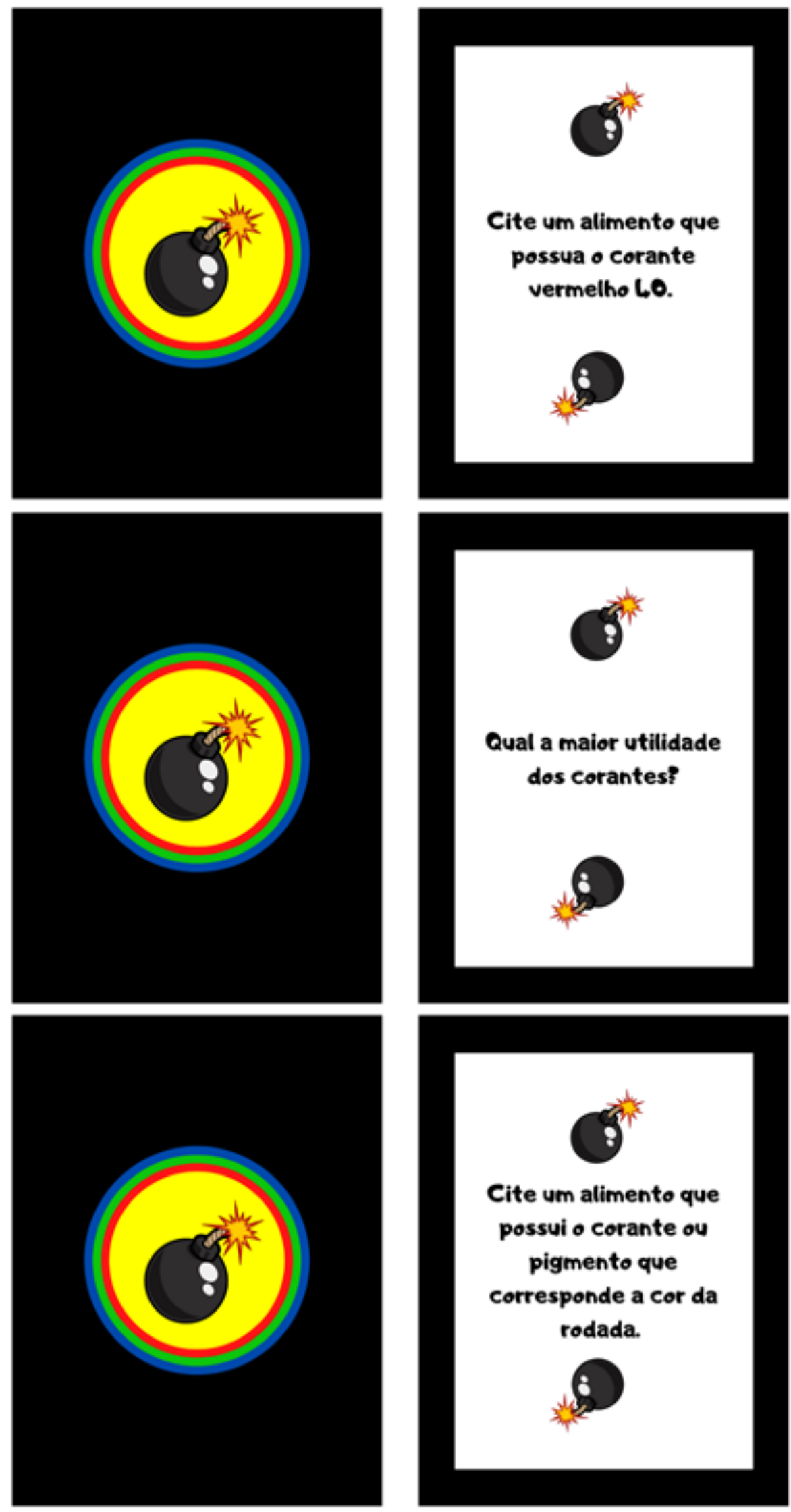

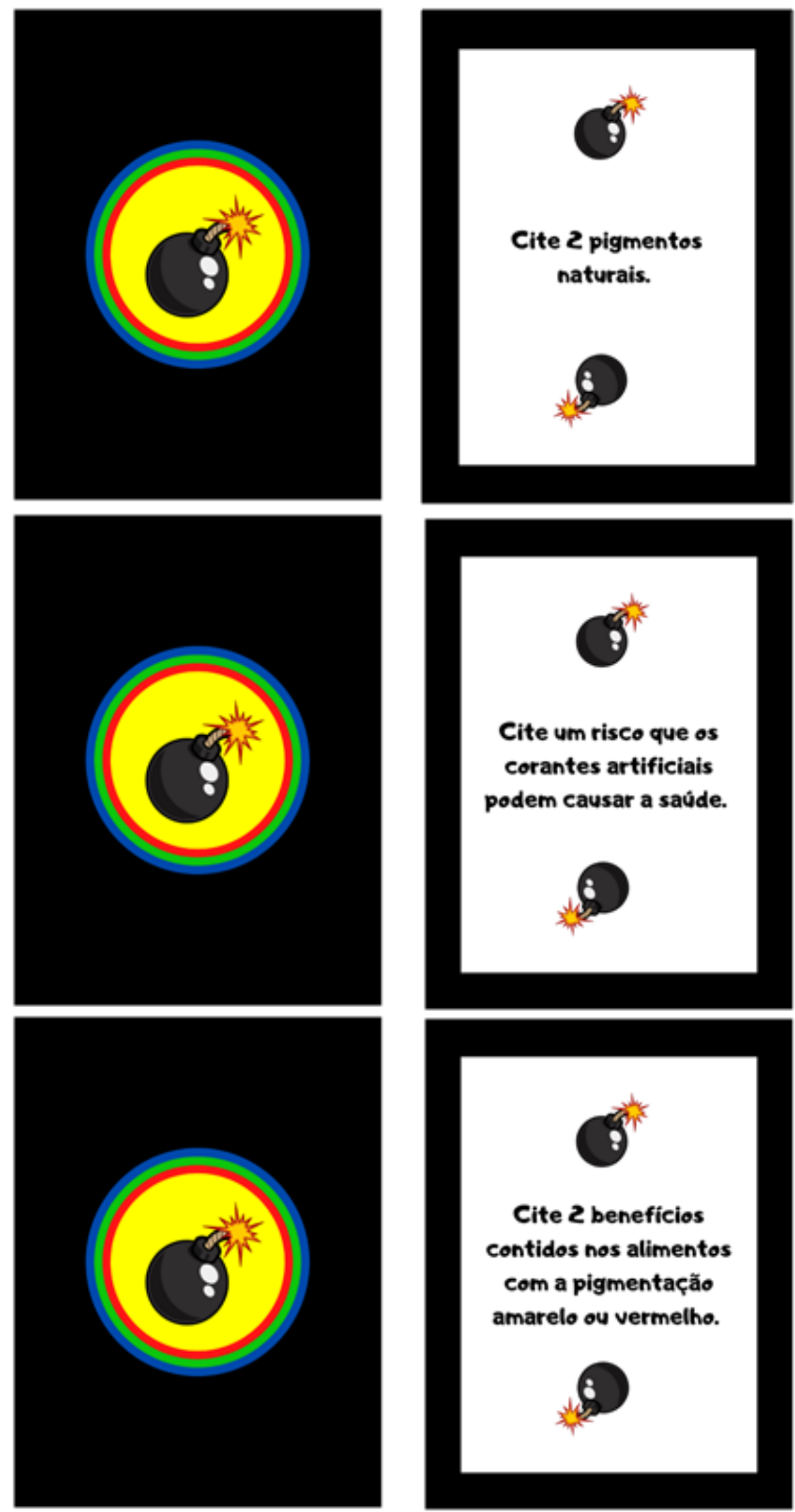


\section{REFERÊNCIAS}

[1] CUNHA, M.B. Jogos no ensino de química: considerações teóricas para sua utilização em sala de aula. Química Nova na Escola, v. 34, n. 2, p. 92-98, 2012.

[2] ROCHA, J. S. e VASCONCELOS, T. C. Dificuldades de aprendizagem no ensino de química: algumas reflexões. XVIII Encontro Nacional de Ensino de Química (XVIII ENEQ) Florianópolis, SC, Brasil - 25 a 28 de julho de 2016. 


\section{Jogo 20}

\section{Operação Secreta}

Dayanne Cipriano Costa da Silva

Maria da Conceição Tavares Cavalcanti Liberato 


\section{INTRODUÇÃO}

$\mathrm{Na}$ indústria de alimentos a combinação de cores e aromas é indispensável para o sucesso do produto. Biscoitos, remédios, refringentes, e muitas outras mercadorias levam a adição de corantes, de naturais a sintéticos a indústria hoje explora um leque máximo de possibilidade. No que se refere ao estudo do assunto, "Corantes, pigmentos e suas aplicações", se tem a preocupação de torná-lo mais didático. É dessa forma que o lúdico entra como ferramenta importante na assimilação dos conhecimentos teóricos e os conhecimentos presentes nos saberes populares, o trabalho em equipe que alguns jogos proporcionam mostram-se capazes de estimular os processos de criatividade, possibilitando uma abordagem de forma diferente do objetivo das ciências (MESSEDER; ROÇAS, 2009).Com isso o jogo operação secreta, tem como proposta o lúdico/educativo, promovendo o trabalho em equipe e estimulando o raciocínio logico, fazendo assim o aluno o despertar do interesse pelo conteúdo.

Objetivo:_A identificação da presença dos diferentes tipos de corantes em alimentos.

Número de jogadores: De 2 a 8 pessoas.

\section{MATÉRIAS E MÉTODOS}

Os corantes hoje são componentes essenciais na indústria de alimentos, uma vez que, alimentos coloridos são preferentemente desejáveis aos olhos. Afim de se trabalhar a compressão sobre corantes e suas aplicações foi feito um jogo inspirado no CóDIGO SECRETO (fabricando pela:Czech Games Edition, Devir).Os jogos despertam o interesse pelo aprendizado e participação na aula, então atividades desse tipo são mais estimulantes e motivadoras, podemos dizer que jogar é um processo de socialização, na qual propõem ao aluno uma interação entre os demais colegas, propiciando assim não somente um processo educativo entre o jogo e conteúdo, mas também um modo de convivência no âmbito escolar (MATOS et al., 2013).

O jogo "operação secreta" conta com:

1. 16 cartas de identificação, divididas em: verdes e amarelas.

- Cartas verdes: Representam os corantes NATURAIS.

- Cartas Amarelas: Representam os corantes SINTETICOS

2. 02 cartas com nomes de pigmentos tóxicos.

- As cartas acima, são denominadas ASSASSINOS, estas se escolhidas durante a partida garante a vitória da equipe adversária, ou seja, GAME OVER.

3. 07 cartas com nomes ALEATORIOS.

- As cartas acima, são denominadas de ESPECTADORES, dado que, essas não apresentam corantes naturais ou sintéticos em sua composição.

- Os espectadores devem ser identificados com as cartas CINZAS presentes no anexo 01.

4. 48 cartas com nomes de alimentos, estas são denominadas CODINOMES. 


\section{GUIA DO JOGO}

\section{Divisão das equipes}

1.Os participantes têm de se dividir em duas equipes.

2.As equipes devem escolher entre: cartas amarelas ou verdes (a equipe que escolher a cor amarela, irá representar os corantes sintéticos, já os naturais serão representados pela cor verde).

3.Cada equipe tem que escolher um capitão.

- Através das dicas dadas pelo capitão, os integrantes devem tentar adivinhar quais alimentos do tabuleiro correspondem a classe de corantes da sua equipe, procurando evitar o assassino. 0 grupo que conseguir descobrir todos os alimentos, será o vencedor.

3.1 Cabe exclusivamente ao capitão saber a localização correta (corante/alimento).

3.2 Os capitães devem garanti que no tabuleiro existam:8 alimentos com corantes sintéticos, 8 com naturais, 1 pigmento toxico e 3 Espectadores.

3.3 Para que o tabuleiro atenda as exigências descritas em "montagem de tabuleiro abaixo"

\section{ATENÇÃO}

NÃO é permitido a utilização de palavras em outras línguas.

\section{Montagem do tabuleiro}

Pegue 20 cartas (codinomes), embaralhando-as e as distribuas em 5 colunas horizontais e 4 verticais.

\section{Instruções}

- Os capitães devem dizer apenas UMA VEZ a palavra associativa.

- Se a palavra tiver relação com mais de um alimento do tabuleiro o capitão deve indicar da seguinte forma:

Obs: Palavra associativa + a quantidade de Codinomes relacionados a ela no tabuleiro.

Exemplo: Para a equipe os corantes naturais, existem no tabuleiro as frutas: maracujá, manga e maçã, no caso para sinalizar aos companheiros de equipe o capitão deve falar: Fruta 03, indicando assim, que no tabuleiro existem três codinomes que sua equipe deve marca.

- Os capitães não devem de modo algum, sinalizar quais nomes no tabuleiro são os ESPECTADORES.

- Em caso de marcação no tabuleiro incorreta:

[1] Os capitães não devem dizer nada.

[2] No caso de alguma equipe achar que a adversaria marcou errado, esta tem o direito de mudar a marcação no tabuleiro. 


\section{ANEX01}

Cartas de Identificação:

8 corantes sintéticos, 8 corantes naturais, 2 pigmentos tóxicos e 3 espectadores
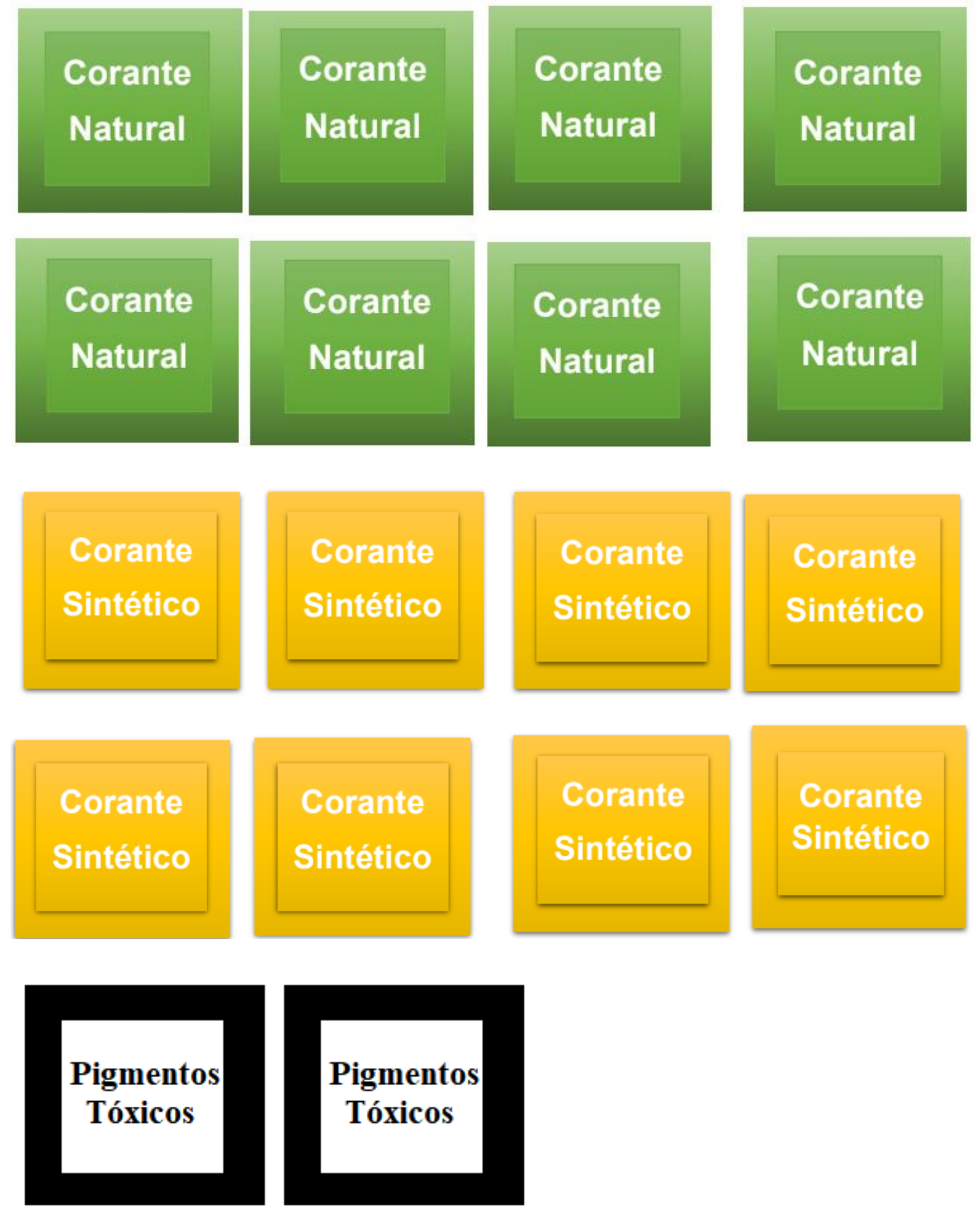

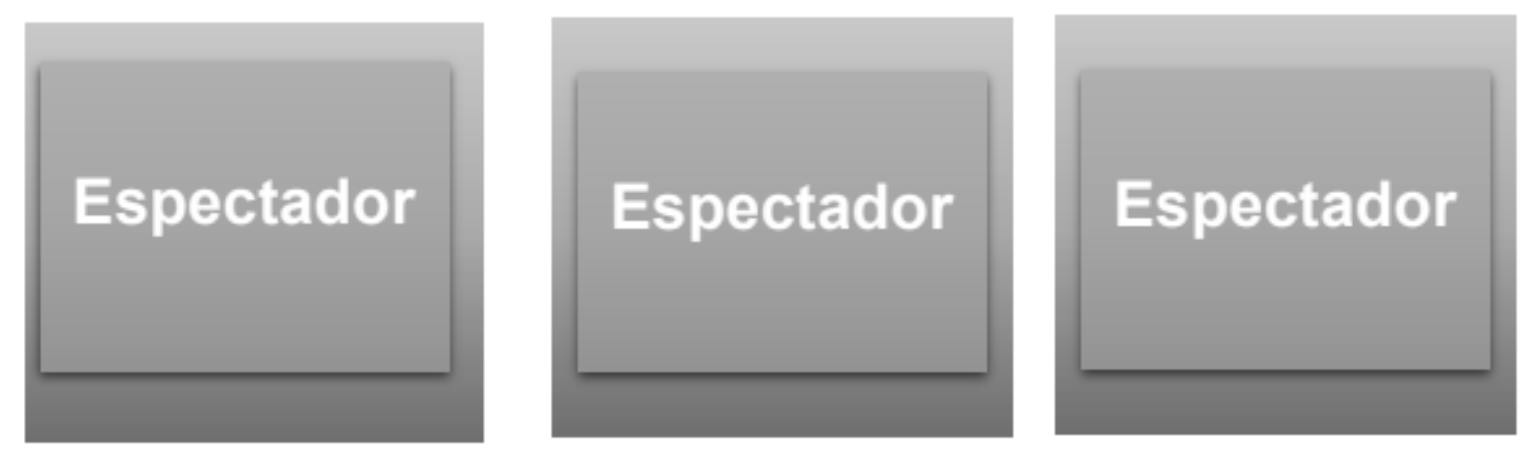

Fonte: Autores.

Alimentos (Cartas Codinomes)
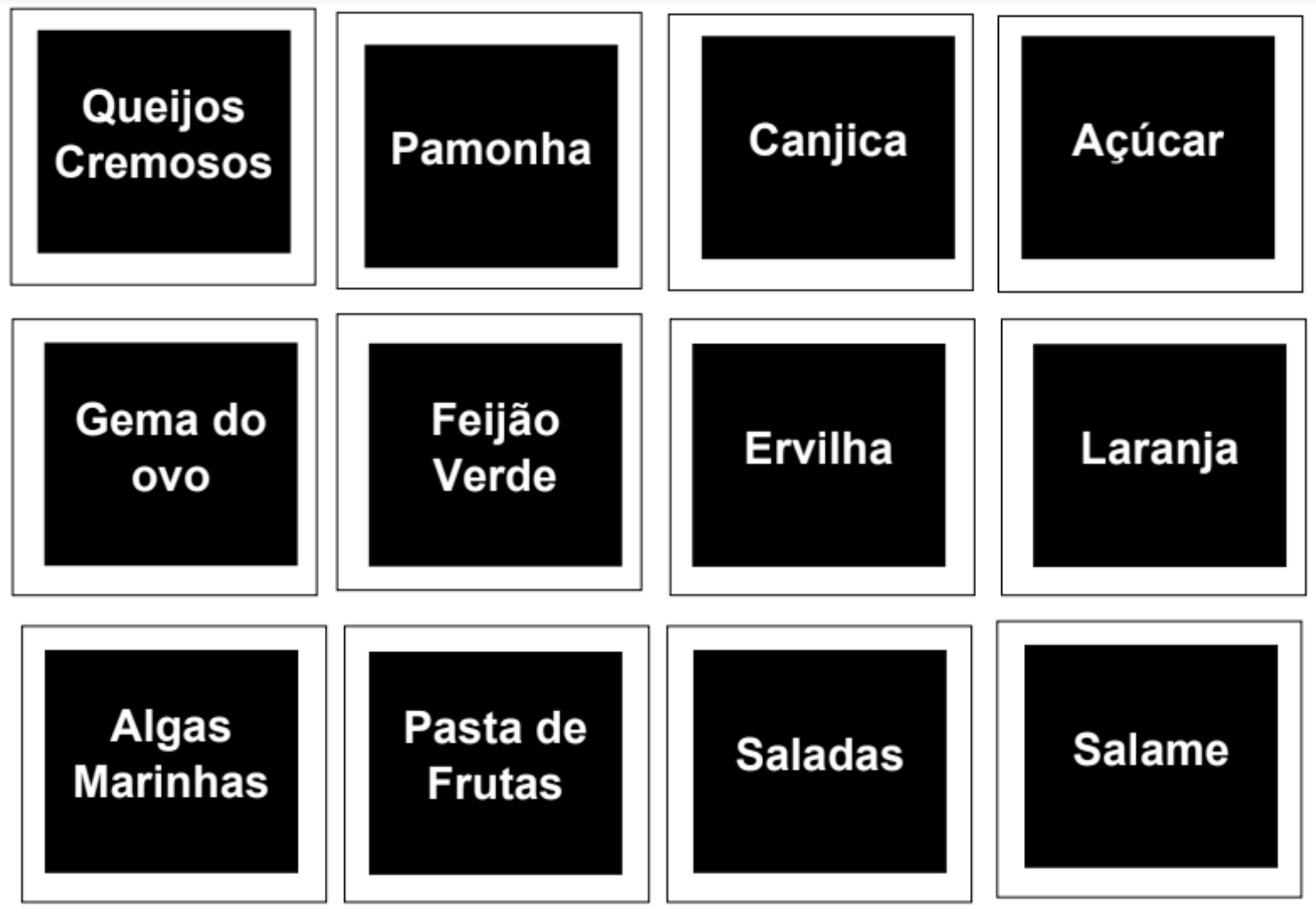

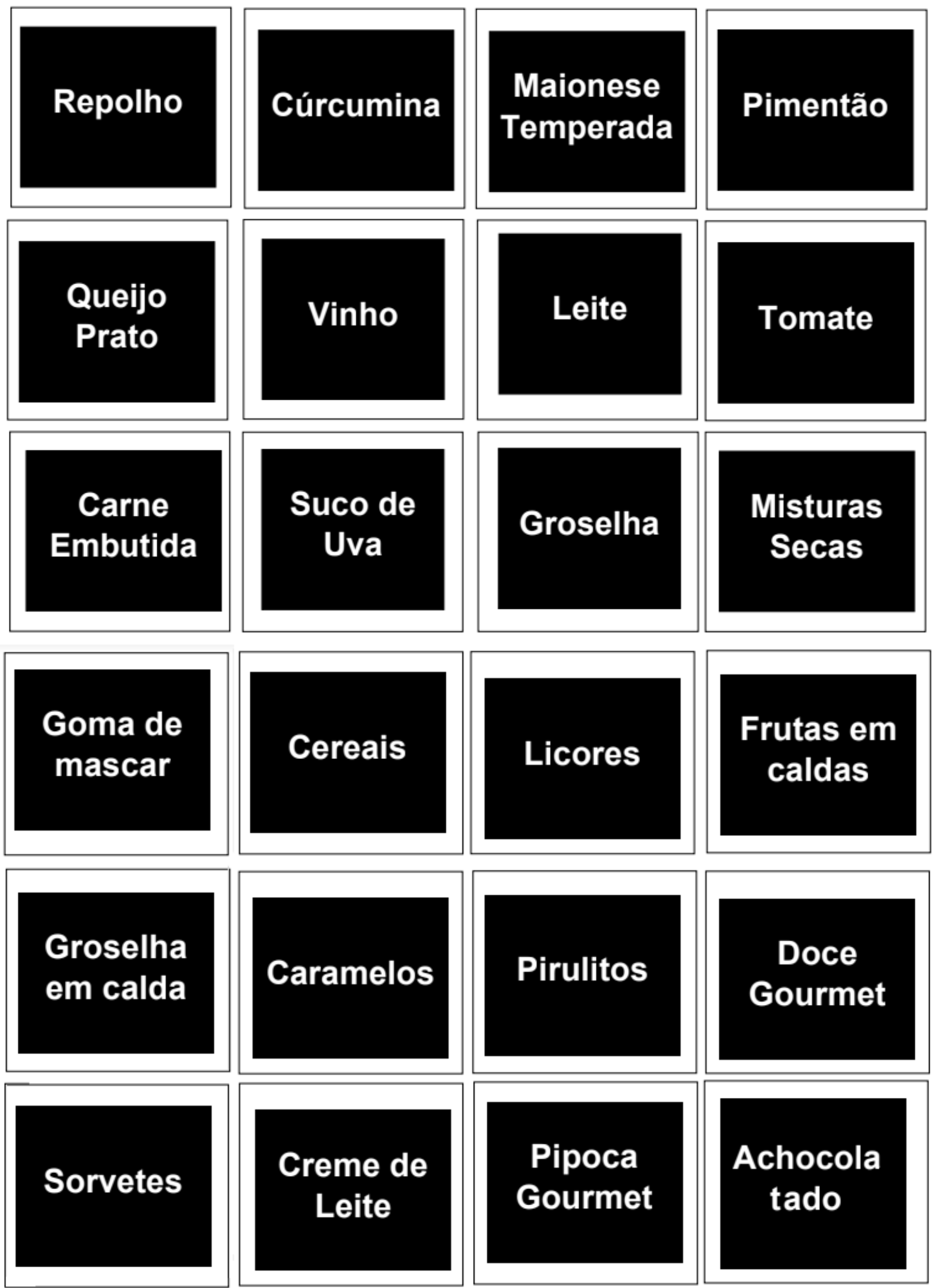

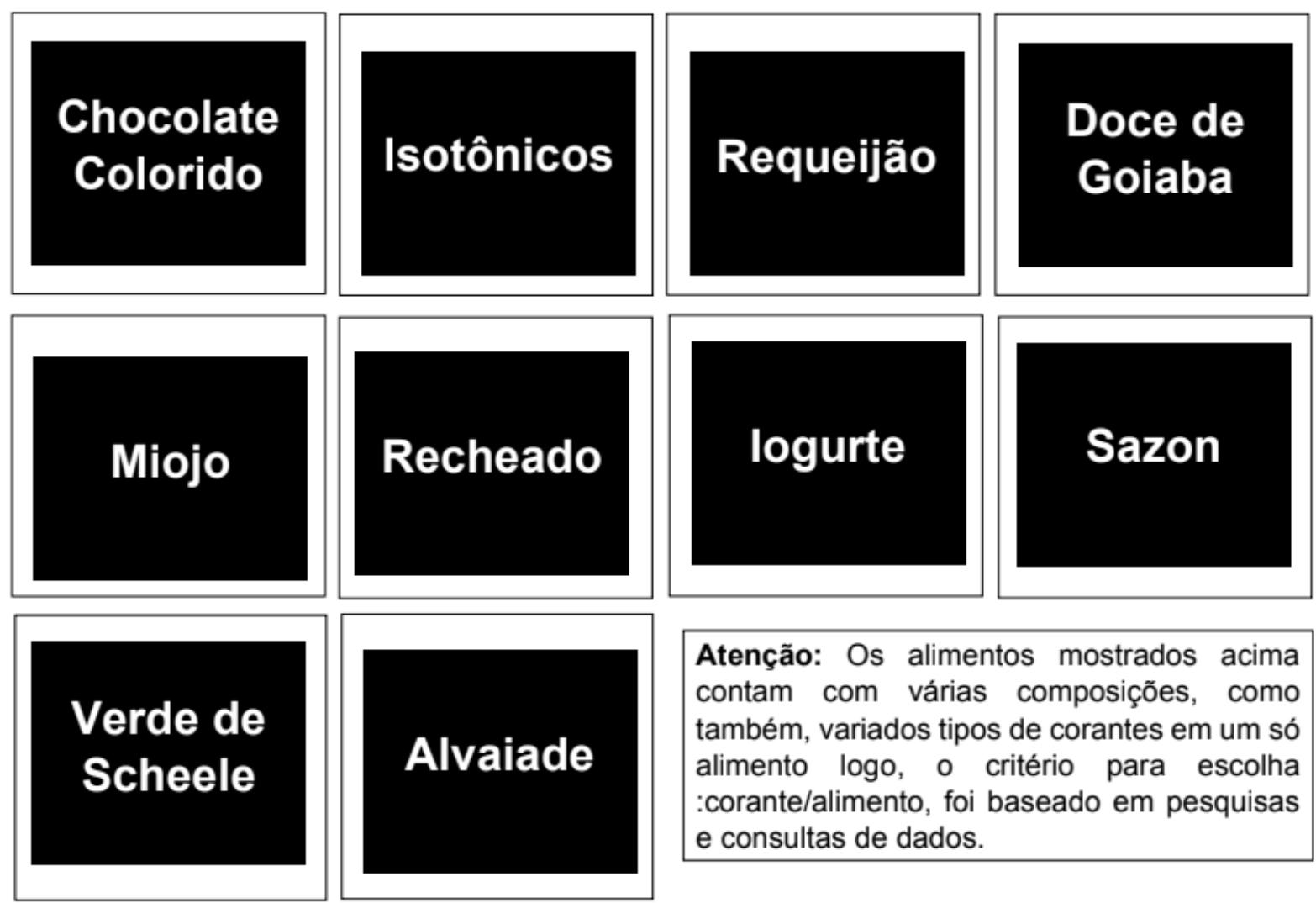

Atenção: Os alimentos mostrados acima contam com várias composições, como também, variados tipos de corantes em um só alimento logo, o critério para escolha :corante/alimento, foi baseado em pesquisas e consultas de dados.
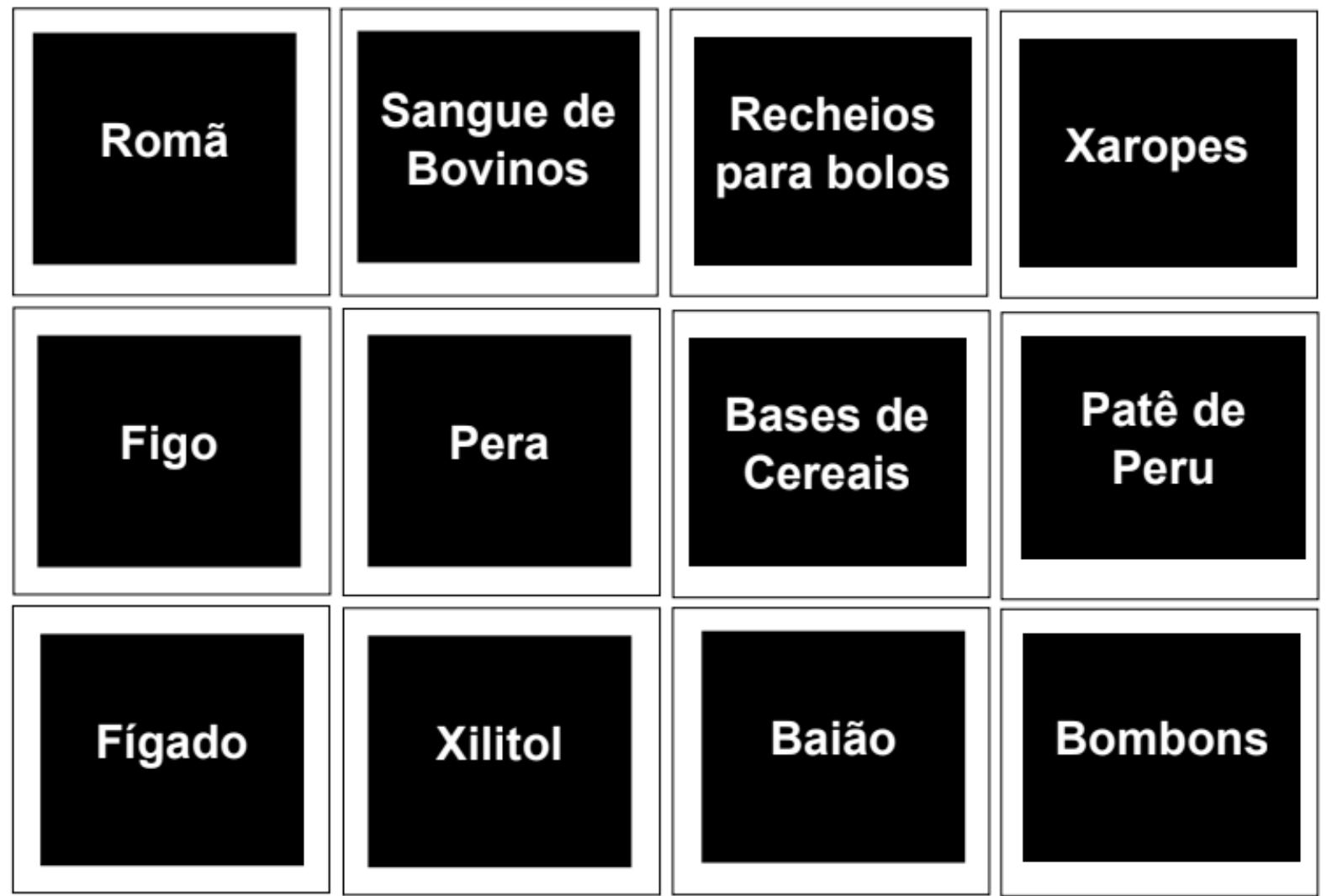

- Anexo para os capitães:

A lista deve ser utilizada, exclusivamente, pelos capitães das equipes.

$\checkmark$ As conexões estabelecidas alimento/corante, foram fruto de pesquisas ao logo da elaboração do jogo. 
$\checkmark$ Os alimentos listados possuem em sua composição mais de um corante ou pigmento, sendo critério para escolher a relação(corante/alimento), a quantidade ou cor final do produto.

$\checkmark$ Com a crescente preocupação com a saúde e aumento na variedade de alimento, as empresas alimentícias voltam seu interesse para a fabricação de alimentos mais saudáveis, levando tal ponto para o mercado consumidor vemos uma substituição gradativa dos corantes sintéticos pelos naturais, ou seja: existem alimentos já fabricados com corante naturais e outros que ainda tem em sua composição os sintéticos.

Obs: 0 autor, em momento algum, está afirmando a existência ou falta de um corante, seja natural ou sintéticos, em algum alimento.

\begin{tabular}{|l|l|}
\hline \multicolumn{1}{|c|}{ Corantes Naturais } & Pasta de frutas \\
\hline Romã & Goma de Mascar \\
\hline Sangue Bovino & Cereais \\
\hline Figo & Licores \\
\hline Pera & Groselha em calda \\
\hline Groselha & Caramelos \\
\hline Mistura seca & Pirulitos \\
\hline Carne Embutida & Doces gourmet \\
\hline Suco de Uva & Sorvetes \\
\hline Tomate & Creme de leite \\
\hline Vinho & Pipoca Gourmet \\
\hline Queijo Prato & Achocolatado \\
\hline Repolho & Chocolate colorido \\
\hline Curcumina & Isotônicos \\
\hline Pimentão & Requeijão \\
\hline Maionese Temperada & Doce de goiabas \\
\hline Algas Marinhas & Miojo recheado \\
\hline Frutas em calda & Iogurte \\
\hline Saladas & Sazon \\
\hline Salame & Recheio para bolos \\
\hline Feijão verde & Xaropes \\
\hline Laranja & Bases de cereais \\
\hline Ervilha & Bombons \\
\hline Gema de ovo & Patê de peru \\
\hline Queijo cremoso & \\
\hline
\end{tabular}




\begin{tabular}{|c|c|}
\hline Alimentos Espectadores & Pigmento Toxico \\
\hline Baião & Verde de Scheele \\
\hline Arroz & Alvaiade \\
\hline Xilitol & \\
\hline Leite & \\
\hline Canjica & \\
\hline Açúcar & \\
\hline Fígado & \\
\hline \multicolumn{2}{|c|}{ Fonte: Autores }
\end{tabular}

\section{REFERÊNCIAS}

[1] BERDICK, M. Safety of food colors In: HANTHCOCK, J. N. (Ed.) Nutritional toxicology. New York: Academic Press, 1982, v. 1, p. 383-434.

[2] CROCE, J. Muita cor e algum risco nas balas. Consumidor S.A. v. 2, p.5-8, 1965.

[3] DOWNHAM, A.; COLLINS, P. Colouring our food in the last and next millennium. Int. J. Food Sci.Technolo., v. 35, p. 5-22, 2000.

[4] MATOS, Danilo Augusto. et al. O Jogo do Mico no Ensino das Funções orgânicas: 0 Lúdico como Estratégia no PIBID. Natal - RN: V CNNQ; III ENNEQ, 2013.

[5] MESSEDER, J. C.; RÔÇAS, G. o lúdico e o ensino de ciências: um relato de caso de uma licenciatura em Química. Revista Ciência \& Ideias, v. 1, n. 1, p. 69-75, 2009

[6] NETTO, R. C. M. Dossiê corantes. FOOD INGREDIENTS BRASIL, n. 9, 2009. Disponível em: . Acesso em: 13 de.sept.2020 .

[7] POLONI, R.; LUCA, M. Corantes naturais frentes às tendências mundiais. Periódico Tchê Química, v. 4, n. 7, p. 33-40, Porto Alegre, 2007. Disponível em:<http://www.deboni.he.com.br/tq/revista/revista7.htm> Acesso em: 13 de. sept.2020.

[8] SOUZA, R. M. CORANTES NATURAIS ALIMENTÍCIOS E SEUS BENEFícios À SAÚDE. 2012. Monografia (Graduação Farmácia), Centro Universitário Estadual da Zona Oeste, Rio de Janeiro, 2012. Orientador: Professor Marco Antônio Mota e Professora Sabrina da Silva Dias.

[9] VEloso, L. A. Corantes e Pigmentos - Dossiê Técnico. Serviço Brasileiro de Respostas Técnicas. Instituto de Tecnologia do Paraná, 2012. 
